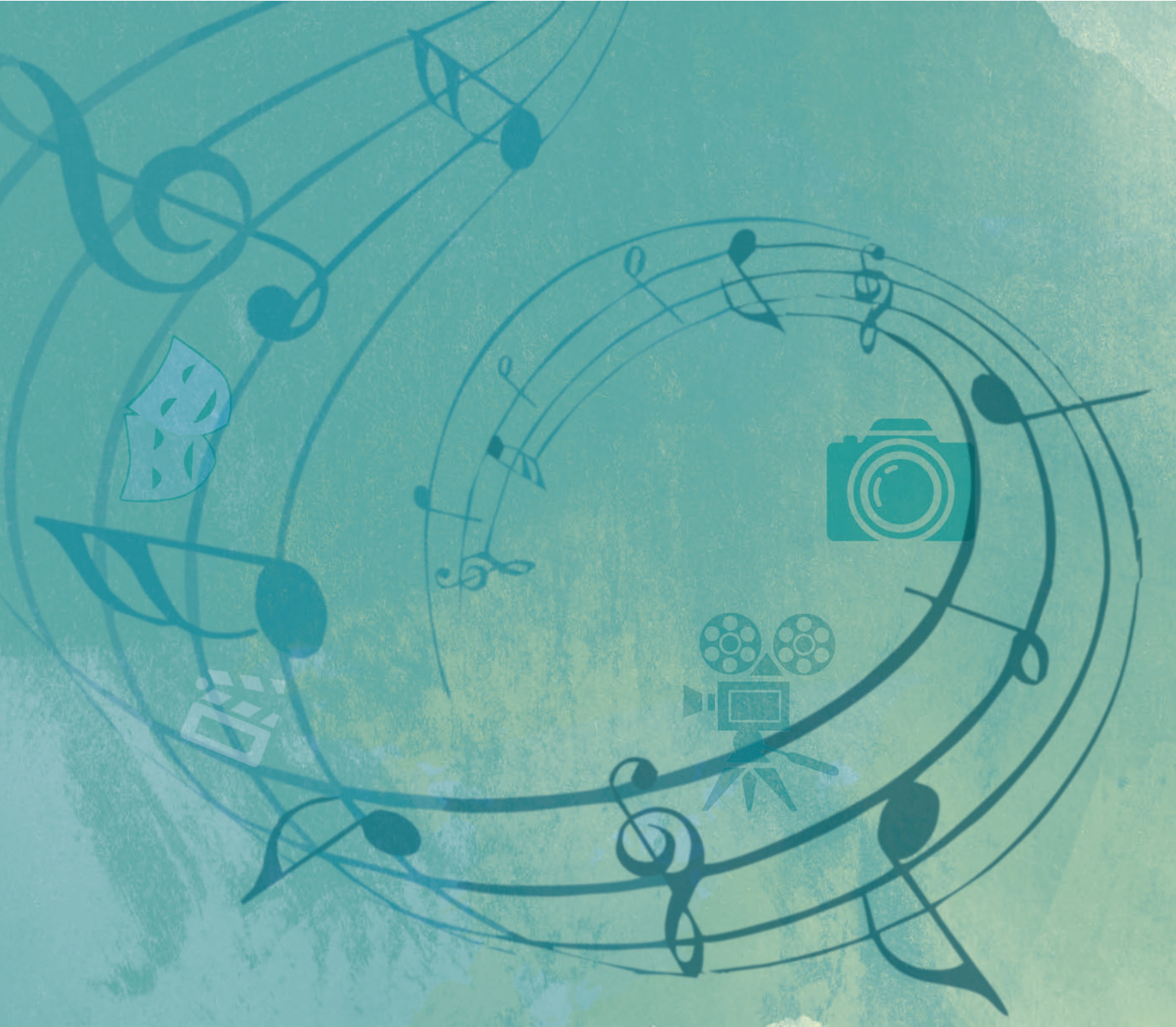

Christianne Luce Gomes

José Alfredo Oliveira Debortoli

Luciano Pereires das Silys!

(Org:)

\title{
Lazer, \\ Práticas Sociais e \\ Mediação Cultural
}

\author{
AUTORES \\ ASSOCIADOS
}


Lazer, Práticas Sociais e Mediação Cultural 
Universidade Federal de Minas Gerais

Sandra Regina Goulart Almeida

Reitora

Alessandro Fernandes Moreira

Vice-Reitor

Escola de Educação Física Fisioterapia e Terapia Ocupacional Gustavo Pereira Côrtes

Diretor

Lygia Paccini Lustosa

Vice-diretora

Centro de Estudos de Lazer e Recreação

Christianne Luce Gomes

Hélder Ferreira Isayama

Coordenadores 


\section{Presidente da República Federativa do Brasil Jair Messias Bolsonaro \\ Ministro da Cidadania \\ Osmar Gasparini Terra \\ Secretário Especial do Esporte \\ Décio dos Santos Brasil}

Secretário Nacional de Esporte, Educação, Lazer e Inclusão Social - SNELIS Washington Stecanela Cerqueira

Diretor do Departamento de Desenvolvimento e Acompanhamento de Políticas e Programas Intersetoriais - DEDAP

Angelo Roger Aroldo de França Costa

\section{Coordenador-Geral de Lazer e Inclusão Social - CGLIS}

Clemente Mieznikowski

Diretor do Departamento de Gestão de Programas de Esporte, Educação, Lazer e Inclusão Social - DEGEP

Clair Tomé Kuhn 

Christianne Luce Gomes

José Alfredo Oliveira Debortoli

Luciano Pereira da Silva

(Org.)

\section{Lazer, Práticas Sociais e Mediação Cultural}

Coleção Educação física e esportes 


\section{Copyright $(2019$ by Editora Autores Associados Ltda.}

Todos os direitos desta edição reservados à Editora Autores Associados LTDA.

Dados Internacionais de Catalogação na Publicação (CIP)

(Câmara Brasileira do Livro, SP, Brasil)

Lazer, práticas sociais e mediação cultural / Christianne Luce Gomes, José Alfredo Oliveira Debortoli, Luciano Pereira da Silva, (Org.). - Campinas, SP: Autores Associados, 2019.

ISBN 978-85-7496-428-7

Vários autores.

Bibliografia.

1. Difusão cultural 2. Lazer - Aspectos sociais 3. Políticas públicas 4. Projetos sociais I. Gomes, Christianne Luce. II. Debortoli, José Alfredo Oliveira. III. Silva, Luciano Pereira da.

\section{EDITORA AUTORES ASSOCIADOS LTDA.}

Uma editora educativa a serviço da cultura brasileira

Av. Albino J. B. de Oliveira, 901 | Barão Geraldo

CEP 13084-008 | Campinas-SP

Telefone: +55 (19) 3789-9000

E-mail: editora@autoresassociados.com.br

Catálogo on-line: www.autoresassociados.com.br

Conselho Editorial "Prof. Casemiro dos Reis Filho"

Bernardete A. Gatti

Carlos Roberto Jamil Cury

Dermeval Saviani

Gilberta S. de M. Jannuzzi

Maria Aparecida Motta

Walter E. Garcia

Diretor executivo

Flávio Baldy dos Reis
Coordenadora editorial

Érica Bombardi

Preparação e revisão

Cleide Salme

Diagramação

Érica Bombardi

Capa e Arte-Final

Érica Bombardi

Imagem de Capa

VECTEEZY.COM

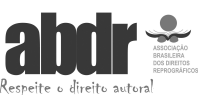

www.abdr.org.br/site/

denuncie a cópia ilegal 


\section{SUMÁRIO}

LAZER, PRÁTICAS SOCIAIS E MEDIAÇÃO CULTURAL: NOTAS

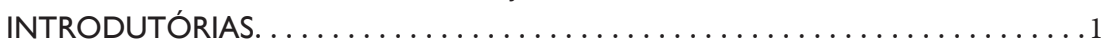

Christianne Luce Gomes, José Alfredo Oliveira Debortoli e Luciano Pereira da Silva

I. "UMA CÂMERA NA MÃO E UMA IDEIA NA CABEÇA": INSTIGANDO O OLHAR POR MEIO DO CINEMA $\ldots \ldots \ldots \ldots \ldots \ldots \ldots \ldots \ldots \ldots$

Christianne Luce Gomes e Mariana Mól Gonçalves

2. A FOTOGRAFIA E A POLÍTICA DO BRINCAR .................27 Jorge Quintão

3. A EXPERIÊNCIA DE BRINCADEIRA $\ldots \ldots \ldots \ldots \ldots \ldots \ldots \ldots \ldots \ldots \ldots$

Eugênio Tadeu Pereira

4. LETRAMENTO DIGITAL: ENTRE A APROPRIAÇÃO E A PROIBIÇÃO DAS PRÁTICAS DIGITAIS DE LAZER NA FORMAÇÃO DE ADOLESCENTES . . . . . 55 Guilherme Carvalho Franco da Silveira e Rafael Fortes

5. HIP-HOP \& EDUCAÇÃO:

UMA BATALHA QUE SE VENCE COM DIVERSÃO ...................75

Cristiane Correia Dias (b-girl Cris), Daniel B. O. Tejera (Daniel Garnet)

e Elaine Cristina Moraes Santos

6. PROJETOS SOCIAIS E DANÇA:

LAZER, EDUCAÇÃO E MEDIAÇÃO CULTURAL .................... 95

Elisângela Chaves, Gustavo Pereira Côrtes e Juliana Araújo de Paula

7. RÁDIO, FUTEBOL E LAZER:

A EXPERIÊNCIA DO ÓBVIO ULULANTE NA RÁDIO UFMG EDUCATIVA . . . . . .111

Elias Santos, Thiago José Silva Santana, Felipe Vinícius de Paula Abrantes,

Marina de Mattos Dantas e Silvio Ricardo da Silva 
8. O ESPORTE COMO CONTEÚDO DE PROJETOS SOCIAIS

Juan Carlos Pérez Morales, Gilmar Tondin e Luciano Pereira da Silva

9. AS LUTAS COMO POSSIBILIDADES DE LAZER

Junior Vagner Pereira da Silva e Rodrigo Barbosa Terra

10. CAPOEIRA E JOGOS CORPORAIS

Coriolano P. da Rocha Junior e Romilson Augusto dos Santos

II. FESTAS, MODOS DE VIDA E PATRIMÔNIO CULTURAL:

EXPERIÊNCIAS DE LAZER NOS RITUAIS DO TEMPO E DO TERRITÓRIO. . . . 185 Joyce Kimarce do Carmo Pereira, Karla Tereza Ocelli Costa,

Sônia Cristina de Assis e José Alfredo Oliveira Debortoli

12. LAZER, PRÁTICAS ALIMENTARES E MEDIAÇÃO CULTURAL:

DISCUTINDO O GASTRONÔMICO

Susana Gastal e Ana Maria Costa Beber

13. TURISMO SOCIAL E MEDIAÇÕES: PROBLEMATIZANDO UM PROJETO DE EXTENSÃO DA UNIVERSIDADE FEDERAL FLUMINENSE ............219 Bernardo Lazary Cheibub

14. MEMORIAL MINAS GERAIS VALE:

O LAZER EM UMA INSTITUIÇÃO MUSEOLÓGICA ..................237

Larissa Maria Santos Altemar e Pamela Emilse Naumann Gorga

15. O TEATRO E O CIRCO NA FORMAÇÃO DO

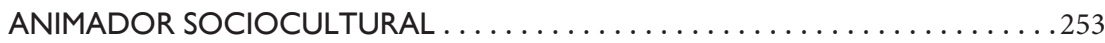

Maria Clara Lemos dos Santos e Rogério Lopes da Silva Paulino

16. ESCOLA DE POSSIBILIDADES SONORAS:

O LIXO QUE VIROU INSTRUMENTO MUSICAL . . . . . . . . . . . . . . . 269

Fernanda Peralta e Regina Café

SOBRE OS ORGANIZADORES E AUTORES DA OBRA $\ldots \ldots \ldots \ldots \ldots \ldots 287$ 


\section{LAZER, PRÁTICAS SOCIAIS E MEDIAC̣̃̃O CULTURAL: NOTAS INTRODUTÓRIAS}

Christianne Luce Gomes

José Alfredo Oliveira Debortoli

Luciano Pereira da Silva

Esta obra tem como objetivo discutir diferentes manifestações culturais vivenciadas como lazer, tais como o cinema, o teatro, a fotografia, a brincadeira, os jogos digitais, a festa, o esporte e a capoeira, entre outras. No campo de estudos do lazer, seja no Brasil ou em outros países, essas atividades são denominadas de "conteúdos culturais do lazer" quando tomam como referência a classificação organizada pelo sociólogo Joffre Dumazedier $(1976,1979)$.

Para classificar as atividades de lazer, o autor francês distinguiu cinco categorias, dependendo do interesse central de cada uma delas. Mesmo que Dumazedier tenha salientado que essas categorias não são estanques e que as atividades de lazer deveriam ser classificadas de acordo com o conteúdo cultural predominante, elas foram divididas em interesses físicos, artísticos, intelectuais, práticos ou manuais e sociais. No Brasil, essa classificação ainda é bastante difundida, tendo sido complementada por Camargo (1980) com os interesses turísticos e, posteriormente, por Schwartz (2003) com os interesses virtuais.

Diversificar o nosso lazer é essencial, ampliando o leque de possibilidades. É também um cuidado necessário a ser tomado pelos profissionais inseridos no campo de atuação profissional do lazer, evitando que os planejamentos contemplem apenas um tipo de interesse, pois isso restringiria a participação das pessoas que não o apreciassem. Contudo, pelo menos três ressalvas podem ser feitas à classificação dos conteúdos culturais do lazer. 
Primeiramente, seria muito difícil - quase impossível - afirmar que uma atividade pertence a determinada categoria, mesmo quando se leva em conta o predomínio do interesse. Ao se envolver com uma atividade físico-esportiva, uma pessoa pode estar muito mais interessada na ampliação de seus laços sociais que naquela prática em si. Outro exemplo pode ser mencionado: enquanto o artesanato é incluído na categoria dos interesses práticos ou manuais porque requer a manipulação que transforma e dá vida a objetos, algumas vezes visando à reprodutibilidade e ao retorno financeiro, a pintura pertence aos interesses artísticos, mesmo apresentando características similares à prática artesanal. É como se o artesanato estivesse privado do imaginário, das emoções, dos sentimentos e do sentido estético atribuídos à pintura e a outras formas de arte.

Uma segunda limitação diz respeito à infinidade de interesses culturais que poderiam compor a classificação proposta por Dumazedier. $\mathrm{O}$ autor enfatiza que toda classificação é finita, mas não é isso que se observa na dinâmica social e cultural do lazer. Seguindo essa lógica, poderíamos agregar outros interesses além dos cinco propostos pelo autor francês, acrescidos pelos turísticos e virtuais. Poderíamos falar, assim, em interesses gastronômicos e religiosos, por exemplo, entre inúmeros outros. Finalmente, a terceira ressalva refere-se ao fato de que as atividades de lazer não são abstratas, precisando por isso ser compreendidas e vividas de modo situado, em íntimo diálogo e interação com cada território, em cada contexto histórico-social e cultural, tanto em âmbito local como global.

Essas considerações iniciais evidenciam que há, portanto, limites a serem considerados quando se pensa na classificação das atividades de lazer. Se esse foi um exercício teórico interessante, que trouxe contribuições para os estudos do lazer especialmente na década de 1970, precisamos ir além, expandindo as possibilidades de experienciar, ludicamente, as diversas manifestações culturais na vida social. Afinal, em diferentes contextos, épocas e lugares, as pessoas brincam, contemplam, festejam, jogam, dançam, cantam, passeiam, sociabilizam, partilham significados e atribuem sentidos aos lazeres vividos. Desse modo, o que entendemos por lazer reveste-se de riqueza sociocultural, detém valor próprio e apresenta complexidades que precisam ser problematizadas (Gomes, 2011, 2014). O lazer não está, por isso, sujeito ao chamado tempo livre, ou encerrado no vazio do "não trabalho", como veremos nos capítulos desta publicação. 
As experiências de lazer são aqui concebidas como práticas sociais que possibilitam o desfrute da vida e a compreensão de mundo, detendo assim um grande potencial para a mediação cultural. Nesse texto, compreendemos o lazer como uma dimensão da cultura que constitui um campo de práticas sociais vivenciadas ludicamente pelos sujeitos, estando presente na vida cotidiana em diferentes tempos e lugares (Gomes, 2014). Por essa razão, é preciso entendê-lo de modo situado em cada território, ou seja, levando em conta algumas das peculiaridades históricas, culturais, sociais, políticas, éticas e estéticas, entre outras, que expressam diversidades e singularidades locais.

As noções de prática social e mediação cultural, em nossas intenções e provocações reflexivas, aproximam-se da abordagem sociológica proposta por Pierre Bourdieu, muito bem discutida em seu livro Esboço de uma teoria da prática ${ }^{1}$, que nos incita a pensar as relações sociais como objeto sociológico e unidade analítica. Essa abordagem propõe articular, na análise sociológica, agência/atores sociais e estrutura, relações de poder e campos possíveis de mediação e ação.

Com esse intuito, convidamos diferentes autores a abordarem uma diversidade de temas que desafiam o lazer em suas ricas possibilidades de experiência e relações sociais, problematizando limites e possibilidades de participação social e efetivação de direitos de cidadania. Muitas manifestações culturais são trabalhadas em projetos sociais, gerando ações e reflexões que buscam qualificar o acesso da população a uma diversidade de práticas, tanto na perspectiva de suas experiências locais quanto na de novos conhecimentos. Assim, esta publicação permite a continuidade da reflexão e a troca de experiências sobre lazer, práticas sociais e mediação cultural.

Considerando o conteúdo desta obra coletiva, aqui temos as notas introdutórias, que explicitam as compreensões adotadas pelos organizadores e apresentam os capítulos e autores aqui reunidos.

O capítulo 1 foi escrito por Christianne Luce Gomes e Mariana Mól Gonçalves. As autoras discutem o cinema, essa experiência de lazer que desperta fascínio nas pessoas através dos tempos. As autoras problematizam o lugar ocupado pela "sétima arte" em nosso contexto, vislumbrando possibilidades para que a experiência cinematográfica contribua com

1 Publicado originalmente em 1972, com edição traduzida para o português pela editora Celta, em 2002. 
a compreensão de mundo e de nós mesmos. Nessa direção, o capítulo busca instigar nosso olhar, enquanto espectadores, para que possamos entender melhor o cinema.

Partindo de reminiscências de sua infância, Jorge Quintão discorre sobre a fotografia como uma política do brincar, tema tratado no capítulo 2. O autor destaca a importância de colocar a técnica a serviço da brincadeira por meio de experimentações, tendo em vista superar o condicionamento do olhar e atribuir significados mais profundos e críticos às imagens. Além de mudar a percepção das pessoas sobre a sua própria realidade, a fotografia é uma forma de empoderamento que detém o potencial de transformar realidades.

O capítulo 3, de autoria de Eugênio Tadeu Pereira, foi dedicado à temática do brincar. Para o autor, o brincar tem muitas miradas e conta com uma vasta bibliografia, assim como descrições que subsidiam o desenvolvimento de brincadeiras e jogos, palavras que se mesclam e se confundem em nossos dias. Mas ambos também podem assumir significados diferentes, dependendo da história de vida de quem usa essas expressões e do ponto de vista escolhido para fazer a reflexão ou praticar essa atividade.

Guilherme Carvalho Franco da Silveira e Rafael Fortes destacam, no capítulo 4, o crescente interesse pelas mídias digitais, que preponderantemente têm sido buscadas por adolescentes como práticas de lazer. Para os autores, elas são uma possibilidade de desfrutar a vida nos dias atuais, construir identidades, compreender e se relacionar com o mundo. Nesse sentido, propõem reflexões sobre o significado de letramento digital e as práticas digitais dos adolescentes que possam ser incorporadas por escolas e projetos sociais.

Cristiane Correia Dias, Daniel B. O. Tejera e Elaine Cristina Moraes Santos compartilham, no capítulo 5, uma experiência educacional dedicada a uma forma de letramento comprometida em mobilizar a juventude afrodescendente periférica: o hip-hop. Os autores sublinham a relevância de articular os saberes dos(as) alunos(as) com os conhecimentos historicamente acumulados mediante a cultura negra, para que haja uma formação étnica, ética e estética baseada em valores e atitudes que possam reverberar no conjunto da sociedade.

O capítulo 6, de autoria de Elisângela Chaves, Gustavo Pereira Côrtes e Juliana Araújo de Paula, provoca-nos uma reflexão sobre a dança como uma forma de expressão complexa que comunica valores, aspirações e 
insatisfações, crenças e linguagens. Os autores problematizam o ensino da dança como possibilidade de educação, tanto no contexto da escola quanto em outros contextos educativos, como os projetos sociais. Trazem reflexões sobre a dança como possibilidade de viver experiências de lazer, exercício de cidadania e participação social.

O capítulo 7 traz uma discussão acerca do rádio, o futebol e o lazer. Elias Santos, Thiago José Silva Santana, Felipe Vinícius de Paula Abrantes, Marina de Mattos Dantas e Silvio Ricardo da Silva compartilham a experiência do Óbvio Ululante, programa na Rádio UFMG Educativa, no qual buscam romper com a suposta imparcialidade do jornalismo esportivo tradicional. Para isso, são propostas interlocuções entre as pesquisas acadêmicas, o jogar e o torcer.

No capítulo 8, os autores Juan Carlos Pérez Morales, Gilmar Tondin e Luciano Pereira da Silva apresentam um texto que nos provoca refletir acerca da importância de qualificar as possibilidades formativas da prática esportiva. Trazem como argumento central a importância de aqueles que trabalham com atividades esportivas estabelecerem uma cultura do esporte que ofereça as mesmas oportunidades para todos e a possibilidade de praticá-lo em todas as suas manifestações.

No capítulo 9, os autores Junior Vagner Pereira da Silva e Rodrigo Barbosa Terra propõem relacionar a prática de lutas e a experiência de lazer problematizando aspectos que historicamente atribuem, a ambos, um tratamento pejorativo, associado a estereótipos e ações desviantes. Discutem metodologias para vivenciar as lutas, ao mesmo tempo preservando suas características básicas e propiciando uma experiência lúdica para seus participantes.

No capítulo 10, de Coriolano P. da Rocha Junior e Romilson Augusto dos Santos, os autores enfatizam a capoeira como uma prática corporal que relaciona significados e tradições, expressando possibilidades de interpretações e elaboração de valores. Somos convidados a observar a experiência e a diversidade de vivências contidas nessa prática, sobretudo para pensar intervenções no campo do lazer como possibilidade formativa e transformadora da realidade.

No capítulo 11, Joyce Kimarce do Carmo Pereira, Karla Tereza Ocelli Costa, Sônia Cristina de Assis e José Alfredo Oliveira Debortoli trazem o texto "Festas, modos de vida e patrimônio cultural: experiências de lazer nos rituais do tempo e do território". Nesse capítulo os autores enfatizam a relação dos estudos do lazer e da antropologia discutindo a experiência 
da festa, apresentando uma rica constituição de subjetividades que emergem de uma intensa partilha do espaço público. Os autores associam temas que emergiram de seus estudos etnográficos salientando processos de constituição identitária com base na relação com o território e os modos de viver.

Susana Gastal e Ana Maria Costa Beber são autoras do capítulo 12, intitulado "Lazer, práticas alimentares e mediação cultural: discutindo o gastronômico". Por entenderem as práticas alimentares como relevantes mediadoras das ações humanas, as autoras abordam a comida e a comensalidade à mesa para além das questões nutritivas, relacionando-as com as dinâmicas da sociedade e com as formas de organização social. Nessa lógica, destacam a aproximação da gastronomia com o lazer e o entretenimento.

No capítulo 13, “Turismo social e mediações: problematizando um projeto de extensão da Universidade Federal Fluminense”, Bernardo Lazary Cheibub discute o turismo como uma manifestação do lazer, com destaque para o turismo social. Para isso, apresenta e problematiza um projeto de extensão desenvolvido desde 2015 na Universidade Federal Fluminense (UFF) que oportuniza vivências turísticas organizadas pedagogicamente na perspectiva da animação cultural.

"Memorial Minas Gerais Vale: o lazer em uma instituição museológica" é o título do capítulo 14, de autoria de Larissa Maria Santos Altemar e de Pamela Emilse Naumann Gorga. As autoras debatem o museu como um espaço de lazer no qual podem ocorrer experiências significativas e reflexivas que vão muito além da contemplação passiva de um visitante que apenas escuta e aprecia. Para isso, apresentam as ações educativas do Memorial Minas Gerais Vale, importante museu que integra o Circuito Cultural Liberdade, em Belo Horizonte.

O capítulo 15, de autoria de Maria Clara Lemos dos Santos e de Rogério Lopes da Silva Paulino, propõe debater as contribuições do teatro e do circo no processo de formação profissional do animador sociocultural. O tema é desenvolvido mediante relatos de experiências de práticas pedagógicas e de projetos desenvolvidos no curso técnico em teatro do Teatro Universitário da Universidade Federal de Minas Gerais - importante ressaltar que esse espaço desenvolve atividades desde 1952. Por isso, o texto que compõe esse capítulo apresenta e debate experiências construídas por essa rica história. 
Por fim, no capítulo 16, intitulado "Escola de possibilidades sonoras: o lixo que virou instrumento musical”, Fernanda Peralta e Regina Café abordam as possibilidades de criação com resíduos recicláveis. Para isso, discutem inicialmente questões contemporâneas importantes, como a preservação do meio ambiente e a geração de resíduos. Posteriormente, apresentam o interessante projeto que transforma materiais recicláveis em instrumentos musicais.

Como se poder notar, cada capítulo desta coletânea foi dedicado a uma manifestação cultural, problematizando experiências que possam enriquecer as reflexões/ações relacionadas aos temas tratados. Por isso, o livro se abre a diferentes linguagens, distintas abordagens, conceitos e perspectivas. Ele é direcionado, principalmente, a pessoas com inserção em projetos sociais de lazer, cultura e esporte interessadas em aprofundar conhecimentos sobre essas temáticas - sejam profissionais, estudantes, professores, gestores públicos, agentes sociais, mediadores culturais e pessoas da comunidade.

Desejamos a todos uma boa leitura!

\section{Referências}

Bourdieu, P. Esboço de uma teoria da prática. Diadema: Editora Celta, 2002. Camargo, L. O. L. O que é lazer? São Paulo: Brasiliense, 1980.

Dumazedier, J. Lazer e cultura popular. São Paulo: Perspectiva, 1976.

Dumazedier, J. Sociologia empírica do lazer. São Paulo: Perspectiva, 1979.

Gomes, C. L. Estudos do Lazer e geopolítica do conhecimento. Revista Licere, Belo Horizonte: UFMG, v. 14, n. 3, p. 1-25, set. 2011. Disponível em: $<$ https://seer.ufmg.br/index.php/licere/article/view/491>. Acesso em: jun. 2018.

Gomes, C. L. Lazer: necessidade humana e dimensão da cultura. Revista Brasileira de Estudos do Lazer, Belo Horizonte: UFMG, v. 1, n. 1, p. 3-20, jan./abr. 2014. Disponível em: <https://seer.ufmg.br/index.php/rbel/article/ view/327>. Acesso em: jun. 2018.

Schwartz, G. M. O conteúdo virtual: contemporizando Dumazedier. Revista Licere, Belo Horizonte: UFMG, v. 2, n. 6, p. 23-31, 2003. 



\title{
CAPÍTULO 1
}

\section{"UMA CÂMERA NA MÃO E UMA IDEIA NA CABEÇA": INSTIGANDO O OLHAR POR MEIO DO CINEMA}

\author{
Christianne Luce Gomes \\ Mariana Mól Gonçalves
}

"Uma câmera na mão e uma ideia na cabeça": esse lema consagrou-se no setor audiovisual brasileiro desde a década de 1960. A frase foi atribuída ao cineasta Glauber Rocha, um dos idealizadores do Cinema Novo - movimento artístico-cinematográfico que, à época, revolucionou a forma tradicional de se fazer cinema no Brasil. Glauber e outros fundadores do Cinema Novo buscaram retratar a realidade social brasileira por meio do cinema, projetando nas telas as contradições sociais, culturais e políticas que marcavam, e ainda marcam, nosso país. Os adeptos do Cinema Novo buscavam explorar o potencial político, social, cultural e histórico da chamada sétima arte ao colocar em evidência as misérias socioeconômicas e as peculiaridades culturais da nossa população. A ideia era essa, e a câmera estava a postos para materializá-la, colocá-la em ação.

Essas considerações iniciais evidenciam que o cinema pode ser tratado não apenas como um produto destinado ao consumo massivo de filmes que propiciam o entretenimento alienante e a evasão da realidade, mas, sobretudo, como uma possibilidade de lazer comprometida com a educação das sensibilidades e com a nossa formação ética e estética.

Seja como for, o cinema é uma experiência de lazer fascinante que cativa espectadores no mundo todo. Assim, este texto objetiva explorar algumas potencialidades dessa arte, que é cada vez mais desfrutada como lazer. Nesse sentido, são propostas reflexões sobre o atual lugar ocupado pelo cinema em nosso cotidiano e sobre a oportunidade que a experiência cinematográfica pode abrir para a compreensão do mundo e de nós 
mesmos. Além disso, o texto busca instigar o olhar espectador de filmes para que se possa entender melhor essa arte. Esses conteúdos serão tratados nas duas partes que compõem este texto.

\section{Cinema: uma forma de ver o mundo e a nós mesmos}

O cinema é baseado na fotografia, mas se distingue dessa forma de arte porque seu principal desafio é colocar as imagens em movimento e projetá-las em uma sucessão tão rápida que é capaz de enganar os olhos, criando uma ilusão de realidade. Mesmo que a pessoa saiba que o que está sendo projetado na tela não é "real", quando ela mergulha por inteiro nessa experiência, acaba vivendo-a intensamente. Assim, o espectador pode conectar-se com os(as) personagens e com as situações retratadas nas telas, emocionar-se, assimilar valores e interpretar o mundo de acordo com sua subjetividade, que é socialmente constituída. Em outras palavras, o cinema é uma arte, uma forma de linguagem e uma experiência de lazer muito interessante, que brinca com a realidade.

Com a invenção do cinematógrafo, no final do século XIX, o cinema constituiu-se como um atrativo entre os espetáculos das feiras livres e divertimento passageiro, barato, popular e, muitas vezes, até mesmo grotesco. De acordo com Flávia Cesarino Costa (1995), é muito difícil para nosso olhar contemporâneo entender que as primeiras projeções e filmes não apresentavam uma narratividade intencionalmente construída, com organização e continuidade. Em seus primórdios, o cinema era pura magia, ilusionismo, encantamento e anarquia.

Ao longo do tempo decorrido entre a primeira sessão de cinema ${ }^{1}$ organizada pelos irmãos Louis e Auguste Lumière e o momento presente, o cinema aprimorou sua linguagem, modos narrativos (sabemos distinguir uma ficção e um documentário, por exemplo), estratégias técnicas e tecnologias. O cinema transformou-se em um dos mercados mais lucrativos do mundo, especialmente nos Estados Unidos. Não é por acaso

1 No dia 28 de dezembro de 1895, em um café em Paris, os irmãos Lumière exibiram de seu cinematógrafo Larrivée d'un train à La Ciotat. Essa sessão ficou conhecida como pioneira na história oficial, por ser a primeira vez que se estabeleceu o que entendemos hoje como uma tradicional sessão de cinema: evento público, com projeção de filmes em uma sala escura, cobrança de bilhetes de entrada, público acomodado em cadeiras etc. 
que, quando falamos em cinema, os filmes hollywoodianos venham à nossa mente quase de forma imediata. A enorme cadeia produtiva que compõe o mercado cinematográfico e audiovisual, em geral, reafirma a importância econômica, social e cultural desse fenômeno.

O cinema é uma parte importante e atrativa da chamada cultura de massa, da indústria cultural e, mais recentemente, é considerado um campo relevante das indústrias culturais e criativas ${ }^{2}$. As incontáveis produções hollywoodianas classificadas como filmes de ação, aventura, drama, comédia, ficção científica e até mesmo as animações, entre outros gêneros, certamente contêm aspectos interessantes, que não devem ser desconsiderados. Contudo, geralmente os filmes blockbuster - produções cinematográficas comercializadas com muito sucesso - são padronizados e seguem um mesmo formato narrativo, técnico e estético, conformando e cerceando o nosso gosto. Além disso, muitas vezes há uma lógica perversa que coloca de um lado os cinemas nacionais (obras produzidas no Brasil e em vários outros países) e, de outro, os blockbusters estadunidenses, que acabam por ocupar quase todas as telas e espaços cinematográficos em nosso país. Essa situação nos leva a indagar: Quais seriam as potencialidades do cinema nos dias atuais?

No livro Ver e poder. A inocência perdida: cinema, televisão, ficção, documentário, Jean-Louis Comolli (2008) questiona, logo no início da obra, por que o cinema ainda resiste diante das imagens massivas vindas da televisão, dos videogames, da publicidade, dos reality shows etc. Podemos complementar essa reflexão com as imagens e conteúdos audiovisuais provenientes da internet, das redes sociais e dos serviços de vídeos sob demanda (como Netflix e Amazon, entre outros). O autor questiona: “O que temos a fazer em relação ao cinema?", e prossegue: "Diante de milhares de telas de televisão ligadas noite e dia ao redor do planeta, como falar, dizer, escutar, ver, enfim, o que nos acontece e como representá-lo sem acrescentar, em vão, mais um ruído ao ruído das vaidades?" (Comolli, 2008, p. 9).

Ao problematizar o lugar contemporâneo do cinema, e, nesse contexto, a importância do documentário, Comolli defende o poder da chamada sétima arte e o valor dos filmes enquanto potências de entendimento de mundo, da realidade à nossa volta e, principalmente, como

2 Para ter acesso a uma discussão sobre o lazer no contexto da economia criativa e das indústrias culturais e criativas, ver o trabalho de Gomes (2015). 
ferramenta de representação, de expressão, de política e de transformação. De acordo com Caixeta e Guimarães (2008, p. 33), "Comolli nos propõe um cinema que vai de encontro ao mundo, que se realiza como práxis, forjando-se a cada passo, 'esbarrando em mil realidades que, na verdade, ele não pode nem negligenciar nem dominar". Comolli defende o cinema em fricção com o mundo e filmes documentários realizados sob o risco do real. Para o autor, o cinema deve sempre ser marcado pela sua realidade e estar em embate direto com ela.

Pensando nos significados e no lema do Cinema Novo, precisamos considerar o cinema para além das salas de cinema, geralmente localizadas nos centros comerciais das grandes cidades, e do consumo privado e individual das residências, pois ele não se restringe a isso. $\mathrm{O}$ cinema é uma experiência coletiva de fruição audiovisual e de transformação. Espaços como os festivais, as mostras de filmes, os cineclubes, as escolas livres, os cursos formativos e as salas de aula podem ser janelas de respiro nas quais o acesso ao cinema acontece de forma mais diversa e ampla. Afinal, como toda arte, o cinema é múltiplo.

Assistir a filmes é uma maneira simples e eficaz de conhecer a própria cultura, e outras culturas também. Quando assistimos a um filme, seja uma comédia escrachada, um terror psicológico, um drama pesado ou um documentário educativo, podemos identificar nele, e como consequência dele, como somos mostrados e como os outros são evidenciados.

Se os filmes abrem portas para vermos e compreendermos o mundo, além de nós mesmos, podemos rir, chorar, sentir emoções, refletir e aprender, entre várias outras possibilidades. $\mathrm{O}$ cinema carrega em si a riqueza áudio e visual de nos contar histórias, narrativas e experiências diferentes e singulares daquelas apreendidas por nós e daquelas apresentadas pelas outras formas audiovisuais hegemônicas já citadas anteriormente. Seja por meio de diferentes gêneros narrativos, como documentários, animações ou filmes de ficção, cada obra carrega um enunciado, uma linguagem, uma trama única e repleta de possibilidades de identificação e aprendizado.

Com base nessa riqueza e nesse potencial, podemos pensar como o cinema é capaz de ser fruído como experiência lúdica, criativa e crítica de lazer que vai além do entretenimento alienante, e utilizado como uma ferramenta, se não ideal, bastante eficaz para a educação e a formação cultural.

O que você pensa sobre isso? Você já parou para refletir sobre sua experiência com o cinema? Qual a origem da maioria dos filmes a que 
você assiste? O que mais chama sua atenção em um filme? O que você mais aprecia e do que não gosta? Por quê? Quais são os critérios que você utiliza para escolher e para avaliar um filme?

Reflexões como essas são um ponto de partida essencial para dialogarmos sobre o cinema como uma fonte preciosa para a educação das sensibilidades, para a formação/transformação ética e estética e para a construção do nosso olhar enquanto espectadores.

A apreciação de qualquer obra audiovisual compreende alguns critérios que vão sendo aprendidos no decorrer de nossas experiências. Tais critérios compõem um tipo de conhecimento que, quase sempre, é negligenciado em nossa formação. Segundo Rosália Duarte e João Alegria (2008, p. 72), “o acesso à diversidade é uma fonte importante de aquisição dos conhecimentos que tornam possível a elaboração de critérios pessoais de avaliação de qualidade". Nesse sentido, assistir sempre ao mesmo tipo de filme dificulta o acesso a diferentes formatos estéticos e narrativos, além de restringir o contato com os distintos modos de narrar que são próprios de outras culturas, línguas e países.

Portanto, é imprescindível expandir nossa experiência com o cinema e ter acesso a conhecimentos que instiguem nosso olhar, que nos auxiliem a avaliar a qualidade dos filmes e das produções audiovisuais, que ampliem nossa capacidade de apreciação e a formação do nosso gosto estético. Baseados em Alain Bergala (2002), Duarte e Alegria (2008) salientam que o gosto é uma disposição que vai sendo formada lentamente, à medida que assistimos a diversos filmes. Nas palavras dos autores, "o contato com bons filmes altera o modo ver e contribui para o desenvolvimento da capacidade de julgamento estético de obras cinematográficas e, por extensão, da produção audiovisual em geral" (DuARTE; Alegria, 2008, p. 74).

Assim, é essencial ampliar as oportunidades de imersão e experimentação em ambientes nos quais seja possível explorar obras cinematográficas valorizadas como objeto de fruição lúdica e também de conhecimento. Esse exercício aguça sensibilidades, suscita emoções e propicia aprendizados, o que é fundamental para a formação dos critérios que cada um utiliza para avaliar um filme ou obra audiovisual.

Considerando esse desafio, quatro possibilidades formativas para o cinema são apontadas por Rogério de Almeida (2014, s/p.):

1. a experiência estética: a relação com os filmes se dá por meio de sensações, somos afetados pelas imagens, aprendemos a fruir; 
2. imersão no imaginário: o filme opera uma mediação simbólica na relação com o mundo, com os outros e conosco mesmos;

3. modelos de existência: o cinema nos põe em contato com arquétipos humanos, com os quais nos relacionamos por meio de identificação/projeção (Morin, 2001);

4. formas de pensamento: embora o cinema narrativo de ficção não opere com conceitos, constitui-se como pensamento, pensa com imagens-movimento e imagens-tempo (Deleuze, 1985; 1990), ensinando modos plurais de pensar, além de ele próprio ser material para o pensamento.

Marcos Napolitano (2003), por sua vez, propõe uma metodologia para guiar a utilização de filmes em sala de aula como atividade educativa em qualquer disciplina, o que também é relevante para qualificar as experiências de lazer por meio da mediação cultural. Para além do conteúdo presente nas "histórias" dos filmes, o autor chama a atenção de como eles podem abrir possibilidades mais vastas e auxiliares na construção do senso crítico dos alunos/espectadores. Há, nesse processo, um desafio inicial a ser considerado:

O problema é que os filmes se realizam em nosso coração e em nossa mente menos como histórias abstratas e mais como verdadeiros mundos imaginários, construídos a partir de linguagens e técnicas que não são meros acessórios comunicativos e, sim, a verdadeira estrutura comunicativa e estética de um filme, determinando, muitas vezes, o sentido da história filmada [Napolitano, 2003, p. 7].

Para superar limitações como essa, o autor destaca que o cinema pode ser utilizado como uma ferramenta poderosa que vai muito além da tarefa de "ilustrar" os conteúdos apresentados em diferentes espaços formativos, sejam salas de aula formais, cursos, mostras, festivais ou espaços de lazer dedicados ao audiovisual. Napolitano (2003) chama atenção para interessantes pontos de análise e desenvolve estratégias para subsidiar o uso de filmes (que também podem ser filmes comerciais) enquanto geradores de debates, pesquisas e projetos práticos, e até mesmo temas transversais e atividades complementares. Para o autor, trabalhar com o cinema em sala de aula "é ajudar a escola a reencontrar a cultura ao mesmo tempo cotidiana e elevada, pois o cinema é o campo no qual a estética, o lazer, a ideologia e os valores sociais mais amplos são sintetizados numa mesma obra de arte" (Napolitano, 2003, p. 11-12). 
As considerações até aqui desenvolvidas nos levam a indagar: De que maneira podemos desenvolver e ampliar nossas possibilidades de apreciar, interpretar e analisar filmes, qualificando nossa experiência cinematográfica? O próximo tópico será dedicado a esse tema.

\section{Instigando 0 olhar}

Para Bourdieu (2007), a capacidade de apreciar e avaliar diferentes obras cinematográficas e audiovisuais não é desenvolvida apenas assistindo a filmes, é preciso aprender a analisar bons filmes. "Bons filmes", segundo o autor, são aqueles que têm seu valor artístico e cultural reconhecidos, que contam com um roteiro bem elaborado, são bem filmados, apresentam densidade e complexidade. Muitos deles são considerados clássicos por terem reconhecido o seu valor histórico, cultural, social, político, técnico, ético e estético.

Você conhece filmes que apresentem essas características? Por constituírem um patrimônio coletivo, é interessante assisti-los, compreendê-los, aprender a apreciar seus diferentes elementos e a avaliá-los.

Um bom filme, para Pierre Sorlin (1992 apud Duarte; Alegria, 2008), desafia e provoca a inteligência do espectador para que ele não se deixe levar pelas impressões mais imediatas da narrativa. Portanto, é preciso empreender um mergulho mais denso na cinematografia.

Filmes de ficção ou documentários podem apresentar uma diversidade de elementos técnicos e criativos que vão muito além de suas tramas, ou seja, da história contada. Muitos deles escapam ao olhar do espectador porque raramente as pessoas têm acesso a esse tipo de conhecimento ao longo de sua formação. Por estarem presos à história do filme, ou seja, ao roteiro, muitos espectadores não percebem que vários outros aspectos precisam ser considerados na apreciação de uma obra audiovisual.

O cinema, como salientado anteriormente, é uma forma de arte e, como tal, possui uma linguagem específica. A experiência lúdica de "fazer cinema" precisa ser incentivada e ampliada, pois abre novas possibilidades de expressão, interpretação e transformação do mundo. O exercício de brincar com a realidade por meio do cinema requer imaginação, mas demanda também alguns conhecimentos e habilidades técnicas que não devem ser vistas como amarras ou "camisas de força" que tolhem 
a criatividade, e sim como um importante recurso para potencializar e materializar tudo isso.

Do ponto de vista técnico, a linguagem cinematográfica é constituída por planos, ângulos, movimentos de câmera, recursos de montagem/ edição, entre outros elementos.

Plano é o enquadramento do que está sendo filmado, e a sua principal referência é a figura humana. Há vários tipos de planos: plano geral, plano de conjunto, plano médio, primeiro plano, close up etc. $\mathrm{O}$ seu tamanho varia de acordo com a distância entre a câmera e a pessoa ou o objeto a ser filmado. Sua escolha depende do conteúdo dramático e material de cada cena: enquanto um plano aberto permite que o ambiente seja visto em sua totalidade, um plano mais fechado enfatiza as expressões do(a) personagem, que ficam mais nítidas. O "plano sequência" é a combinação de vários planos com o objetivo de registrar, sem cortes (ou com cortes não percebidos pelos espectadores), a ação de uma sequência completa.

O ângulo é determinado pela posição da câmera em relação ao que está sendo filmado. Essa angulação pode ser normal (na linha dos olhos), inclinada, de cima para baixo (comumente chamada de plongée) ou o contrário (contra-plongée). Cada ângulo produz um efeito específico na linguagem cinematográfica, podendo engrandecer ou rebaixar um(a) personagem, por exemplo.

Os movimentos de câmera explicitam os pontos de vista da narrativa. Exemplificando, enquanto em uma panorâmica a câmera gira em torno de seu próprio eixo sem sair do lugar (movimento de rotação), em um travelling ela se desloca sobre um trilho com o objetivo de se aproximar ou se afastar do objeto filmado, seja horizontal ou verticalmente (movimento de translação). No zoom, a câmera fica imóvel e o efeito de afastamento ou aproximação é propiciado pelas lentes da câmera. $\mathrm{O}$ que é filmado com um SteadyCam (câmera na mão) objetiva expressar desequilíbrio e instabilidade, entre outros recursos que são empregados em cada movimento da câmera. Assista a um filme e tente observar esses elementos.

Montar, no contexto da linguagem cinematográfica, significa selecionar, organizar, encaixar, juntar as imagens captadas pela câmera. O processo de montagem e edição consiste na ordenação dos planos e das cenas filmadas considerando a sequência definida no roteiro, o que demanda um cuidadoso trabalho de aprimoramento técnico e artístico 
desse material, visando produzir significação em contextos narrativos, dramáticos, visuais, sonoros etc.

Da concepção do filme à sua projeção na tela, é requerida uma série de procedimentos, que são realizados nas fases de pré-produção, produção e pós-produção da obra. A seguir, apresentamos alguns dos procedimentos adotados em filmes que envolvem grande orçamento (hollywoodianos, por exemplo), como também naqueles de custo mais acessível, como é comum no chamado cinema independente.

- Roteiro - é preparado em dois formatos específicos para o cinema. Um deles é o roteiro literário, que traz o argumento, ou seja, a história que será contada. Um filme baseado em um livro precisa ser adaptado para o audiovisual, pois roteiro literário de cinema e literatura são formas distintas de arte. $\mathrm{O}$ roteiro narra a trama e destaca os diálogos, apresenta e caracteriza cada personagem, explicita a quantidade de cenas que compõem o filme e as locações a serem utilizadas em cada uma delas. Pode seguir uma narrativa linear com início, meio e fim ou não adotar uma ordem lógica e cronológica; pode ter um desfecho específico ou instigar a imaginação do espectador com um final aberto, intencionalmente inconcluso. Todos os profissionais envolvidos com o filme precisam ter acesso ao roteiro para compreender em que consiste a narrativa. Tendo como referência o roteiro literário, $\mathrm{o}(\mathrm{a})$ diretor(a) prepara $\mathrm{o}$ roteiro técnico, que é totalmente construído com o uso da linguagem cinematográfica. Em filmes documentários é comum o roteiro ser reformulado no decorrer ou ao final do processo.

- Produção - aqui entra em cena a mão na massa. A produção é a equipe encarregada de colocar o filme escrito (roteiro) em prática, com tudo pronto para ser filmado, da forma que o(a) diretor(a) idealizou na história. A equipe de produção varia de tamanho, de acordo com o orçamento, com a proposta e as necessidades do filme (curta, média ou longa-metragem); pode simplesmente ser composta pelo(a) produtor(a) executivo(a), diretor(a) de produção e produtor(a) de base. $\mathrm{O}(\mathrm{A})$ produtor(a) executivo(a) é quem se responsabiliza pelas contratações, documentos jurídicos e fiscais, administra o orçamento do filme e assina, com o(a) diretor(a), pela inscrição de projetos em leis de incentivo. A direção de produção é 
responsável pela organização geral e operacional do filme e, com o(a) assistente de produção de base, levanta as necessidades do filme, resolvendo-as na prática. A produção planeja toda a logística e a estrutura (compra de insumos e contratação de profissionais) para as filmagens e segue até as últimas fases de um filme, que são a difusão e a exibição.

- Direção - o(a) diretor(a) do filme, ou cineasta, é responsável pelas escolhas narrativas, técnicas e estéticas do filme, e estas são muito subjetivas. Na construção da linguagem cinematográfica, cabe a esse profissional definir de que maneira a trama será materializada no audiovisual. Por isso, precisa dominar conhecimentos técnicos e estéticos que são próprios do cinema. Para desenvolver a narrativa por meio da linguagem cinematográfica, o(a) diretor(a) prepara o roteiro técnico, indicando os planos escolhidos para filmar cada cena, os ângulos e os movimentos de câmera que serão realizados. Nesse processo, define os distintivos estéticos que marcarão sua obra de arte. Tudo precisa ser bem planejado para se obter a melhor forma de expressão artística, sendo as escolhas estéticas do(a) cineasta, em alguns casos, reconhecidas como uma assinatura autoral. Ao escolher um enquadramento, o(a) diretor(a) considera o seu efeito visual separadamente e também como ele se encaixa na narrativa cinematográfica como um todo. $\mathrm{O}$ mesmo acontece com relação às músicas e áudios que irão compor a trilha sonora do filme. De modo geral, o(a) cineasta atua na linha de frente de um filme integralmente: responsabiliza-se pelas escolhas narrativas, técnicas e estéticas da obra, bem como pela sua execução de filmagem; discute com a produção sobre o orçamento e o cronograma, lidera e supervisiona o trabalho dos profissionais que compõem a equipe técnica, seleciona e orienta o elenco quanto à interpretação e performance (gestos, expressões faciais, entonações de voz e detalhes necessários para a composição de cada personagem), dirige ensaios e filmagens, conduz a montagem e a edição do filme ("decupagem") até que o produto final seja alcançado. Obviamente, para que tudo isso seja possível, é preciso contar com uma boa equipe de profissionais, cada um se encarregando de cumprir determinada função. 
- Fotografia - do ponto de vista imagético, a narrativa cinematográfica materializa-se por meio da luz, o que demanda dar asas à criatividade e instigar o olhar fotográfico, colocando todo o aparato técnico em função de câmeras, lentes, filtros, iluminação, enquadramentos, movimentos, exposição, contraste, textura e cor, por exemplo. Tudo isso é de responsabilidade da direção de fotografia, que é incumbida de criar a atmosfera do filme e potencializar seu conteúdo dramático e artístico com formas e cores, luzes e sombras, com o intuito de encantar olhos. Esse profissional precisa ter domínio de fotografia, pois as palavras escritas no roteiro literário, com as indicações do roteiro técnico, devem ser traduzidas em imagens que serão exibidas nas telas do cinema (e também de computadores, tablets, smartphones e TVs). Por isso, as locações selecionadas para as filmagens, os cenários, objetos e figurinos precisam passar pelo crivo do "olhar fotográfico". A direção de fotografia também leva em consideração as cores predominantes no filme: enquanto as mais quentes, como o vermelho, expressam emoções fortes, como paixão, agressividade ou violência, o azul, classificado como uma cor fria, transmite calma e tranquilidade, tristeza ou até frieza, entre outras sensações, dependendo da tonalidade escolhida. Esse exercício requer domínio de fotografia, conciliando experiência técnica e sensibilidade estética, além de acompanhamento dos avanços tecnológicos nesse campo, visando inovar com os conhecimentos e as ferramentas de que dispõe.

- Direção de arte - a arte de um filme engloba tudo o que está relacionado às cores, aos objetos, aos figurinos, ao cenário, à maquiagem e a outros elementos cênicos que compõem a estética cinematográfica. Como mencionado, a cor é uma questão tanto técnica quanto estética e tem a ver com os valores e as intenções do filme: ela reforça a realidade em uma obra cinematográfica mesmo quando esta é produzida em preto e branco, sendo também imprescindível na criação da atmosfera psicológica e/ou dramática. O figurino e a maquiagem correspondem ao estilo de direção, podendo ser destacados para evidenciar gestos e atitudes dos(as) personagens, conforme postura e expressão, e/ou serem mais sóbrios e naturalistas, 
para a construção dos(as) personagens. É por meio do figurino que um(a) personagem reforça um período ou uma época, podendo ser realista (para isso, documentos de época são consultados para reproduzir fielmente a indumentária, o vestuário dos(as) personagens), pararrealista (inspira-se na moda da época, mas dá lugar a uma estilização) ou simbólico (não importa a exatidão histórica, e sim a intenção dramática ou psicológica). A direção de arte também se encarrega dos cenários - sejam eles reais ou construídos, em ambientes internos ou externos - e de todos os objetos em cena, desde a locação. Tudo é minuciosamente escolhido, do mobiliário ao broche colocado no vestido de uma personagem. A direção de arte acaba sendo mais notada em filmes de época e de ficção científica, mas existem diretores de cinema que possuem características tão marcantes em suas escolhas de arte que são facilmente identificados.

- Som - pode-se dizer que o cinema é uma forma de arte concretizada pela união entre imagem em movimento e som, e esses dois elementos precisam estar em perfeita sintonia. $\mathrm{O}$ som participa da estética do cinema e é essencial na experiência cinematográfica, facilitando a compreensão da narrativa e conferindo dramaticidade às cenas. Ele é fundamental para construir determinada atmosfera psicológica para as imagens projetadas na tela - seja um clima de tensão ou um ambiente romântico -, exaltando emoções. Isso é possível por meio de sons captados da fala, dos ambientes, dos silêncios, dos efeitos sonoros, das canções e melodias. Os diálogos, os efeitos sonoros e as músicas compõem a banda sonora de um filme, incluindo os momentos de silêncio e os ruídos de objetos e animais, por exemplo. A voz off - muito comum em documentários - pode ser um interessante recurso de narração, também adotado para expressar os pensamentos e as ideias dos(as) personagens.

- Montagem e edição - diferentemente do que ocorre no momento de produção (a ordem das cenas a serem filmadas é indicada no roteiro técnico), como foi destacado anteriormente, a montagem segue o que está definido no roteiro 
literário. Construindo a duração e a fluidez de cada uma das cenas, bem como os tipos que cortes que serão feitos entre elas, a montagem e a edição implicam escolhas que podem enriquecer a narrativa cinematográfica ou promover o efeito contrário, empobrecendo-a. O andamento de cada plano e a justaposição entre eles e as cenas, entre outros aspectos, são encarregados de produzir significações. Sequências mais curtas sugerem rapidez e dinamismo, e as mais longas podem significar tédio e monotonia, por exemplo. Dessa maneira, o fluxo e a duração do tempo, no cinema, podem ser amplamente manipulados sem nenhum tipo de objeção quando isso está no contexto da narrativa, podendo ser contraídos ou dilatados para fazer referência ao presente, passado e futuro.

Os resultados de todo esse processo culminam na materialização dos filmes a que assistimos, seja no cinema ou em vários outros espaços. $\mathrm{O}$ ato de ver um filme se completa com a própria experiência do espectador. Lançando mão de sua bagagem cultural, social e política de mundo, é o espectador quem vai decifrar, compreender, gostar, analisar, criticar e empreender qualquer outra ação em relação ao filme assistido. Isso demanda uma relação ativa entre o espectador e a obra audiovisual.

Somente o espectador crítico e atento para as várias facetas da realidade dos e nos filmes - e para a realidade do mundo ao nosso redor - é que o cinema se transforma em experiência. Tomás Gutiérrez Alea (1983), na obra Dialética do espectador, chama atenção sobre como a realidade é múltipla, e da mesma forma também são os filmes. O cineasta cubano ressalta que o espectador é quem deve duvidar e questionar tudo aquilo que vê. Para ele, o cinema é um mediador do processo de compreensão e transformação da realidade. E para que essa relação viva aconteça é preciso ampliar as formas de ver, experienciar e ter acesso aos filmes. Afinal só poderemos completar as histórias a que assistimos apoiados em um universo e em visões de mundo mais amplas e diversificadas.

o cineasta elabora a narrativa, mas é o espectador que recompõe a história, que a traduz. Compreender uma obra, interpretá-la, presume uma atividade formativa, não só pela dimensão cognitiva, de pensamento, mas também por ativar a sensibilidade, a imaginação, isto é, a capacidade de dotar de sentidos a experiência vivida [AlmeidA, 2014, s/p.]. 
Segundo Rogério de Almeida (2014), um filme não tem finalidade educativa a priori, mas existe esse uso pedagógico, que consiste em tomá-lo como discurso ou representação da realidade. Seguindo essa linha de interpretação, os filmes (ou trechos deles) podem ser utilizados como recurso auxiliar para exposição de um conhecimento. Esse cuidado torna-se fundamental para que a sessão de cinema não seja um "substituto de aula, atividade diversionista sem compromisso com o trabalho reflexivo e formativo" (AlmeidA, 2014, s/p.).

Transformar o cinema em uma mera distração seria, assim,

uma forma de anestesiar o espectador, tirá-lo do seu cotidiano sem necessariamente instigar a reflexão ou o pensamento, sem lhe possibilitar questionar o próprio cotidiano em que vive. E isso porque compactua, ideológica e esteticamente, com o reforço de dadas convenções, principalmente as produtivistas, que medem o homem pelos resultados de seu trabalho, que entendem formação de maneira instrumental e veiculada à profissão e compreendem a fruição estética propiciada pelas artes como uma atividade ligada ao ócio e à distinção de classe [AlmeidA, 2014, s/p.].

Por isso é importante considerar o cinema uma experiência de fruição no lazer, além de uma possibilidade formativa de mediação cultural que clama por compreensões estéticas, como antes pontuado, e éticas também. Éticas, porque o cinema tem um enorme potencial de produzir e reproduzir valores, o que também precisa ser captado pelo nosso olhar. De acordo com Fischer (2009), alguns exercícios de imersão nas linguagens audiovisuais podem contribuir com esse propósito, o que requer o acesso a filmes que escapem aos padrões convencionais, com o propósito de sugerir a cada espectador uma elaboração ética de si mesmo.

Precisamos, cada vez mais, aproveitar o potencial do cinema para refletirmos e debatermos com mais profundidade sobre as violências físicas e simbólicas presentes em nosso cotidiano, sobre as desigualdades sociais, o consumismo e a destruição do meio ambiente, sobre as guerras, o mito do amor romântico, sobre questões existenciais, desigualdades de gênero e discriminações de raça/etnia, sobre as contradições geradas pelo avanço das tecnologias, a escassez de referências éticas altruístas, sobre nossos sonhos e utopias sociais, entre muitos outros assuntos presentes nos filmes que vemos. Como nos diz Fischer (2009, p. 97), tal exercício exige capacidade intelectual, além de uma "bagagem de informações 
com o objetivo de fazer da experiência de ver também um espaço privilegiado de transformação de nós mesmos".

\section{Considerações finais}

O cinema é um campo de interação simbólica no qual os sujeitos constroem e compartilham significados, como nos lembra Rivoltella (2005). Diversas práticas sociais se entrecruzam no cinema fazendo com que essa forma de arte seja, ao mesmo tempo, experiência de lazer, documento histórico, veículo de consciência intercultural, instrumento de difusão de costumes, formas de vida e patrimônios culturais da humanidade, bem como uma rica oportunidade de reconhecimento local. O cinema também é um agente de socialização na medida em que favorece encontros consigo mesmo, com outras pessoas, com as narrativas cinematográficas, com diferentes culturas e com imaginários sociais. Por isso, o citado autor destaca as possibilidades de educar para o cinema, com o cinema.

Muitas pessoas, em seus momentos de lazer, procuram assistir aos filmes que estão em cartaz, os quais sabemos serem majoritariamente produzidos nos Estados Unidos. Essa produção é importante, mas não é suficiente para ampliar a nossa experiência cinematográfica porque ela segue um mesmo padrão estético e narrativo: "o padrão do cinema hollywoodiano, hegemônico hoje no mercado mundial", como enfatizam Duarte e Alegria (2008, p. 75). É preciso, assim, ver filmes de origens diferentes, que apresentem diversidade estética, narrativa, geográfica e cultural; aprender a decifrar e a avaliar os filmes considerados notáveis; conhecer diretores reconhecidos pelo seu trabalho no cinema, bem como a história e os movimentos estéticos e políticos que tornaram possível a realização de determinados filmes. Nesse processo, é necessário apreciar os detalhes de cada obra audiovisual por meio de estratégias de mediação em espaços formativos, em mostras culturais ou em festivais de cinema, considerando forma e conteúdo.

Outra possibilidade interessante é aventurar-se na sétima arte "fazendo cinema": escrevendo roteiros, produzindo audiovisuais, editando filmes. Considerando o contexto de oficinas, projetos sociais e de lazer, esse exercício pode ampliar conhecimentos e experiências sobre o cinema, aguçar sensibilidades, favorecer a apropriação coletiva e criativa da linguagem cinematográfica, propiciar releituras éticas de mundo, desenvolver habilidades técnicas e o gosto estético. 
Nesse instigante exercício, a técnica precisa ser apreendida como uma parceira, o que será essencial para que as possibilidades lúdicas e criativas do cinema se manifestem e floresçam, alcançando os propósitos almejados. Isso pode ser colocado em ação com o auxílio de meios e recursos alternativos, bem como pelas câmeras cada vez mais sofisticadas de muitos aparelhos celulares. Os resultados desse processo coletivo podem ser projetados até mesmo na parede, incentivando o grupo a se aventurar e a aprimorar mais e mais a sua experiência com o cinema.

$\mathrm{O}$ que você pensa sobre as possibilidades destacadas neste texto? Esperamos que elas sejam um ponto de partida para novas reflexões, apropriações, aprofundamentos e ações sobre o cinema: essa janela que se abre para o mundo.

\section{Referências}

Almeida, R. Possibilidades formativas do cinema. Rebeca - Revista Brasileira de Estudos de Cinema e Audiovisual, [S.1.], ano 3, edição 6, jul./dez. 2014. Disponível em: <https://rebeca.socine.org.br/1/article/view/118>. Acesso em: 6 maio 2018.

Bergala, A. L'Hyphotèse cinéma: petit traité de transmission du cinéma à l'école et ailleurs. Paris: Cahiers du Cinéma, 2002.

Bourdieu, P. A distinção: crítica social do julgamento. São Paulo: Edusp, 2007.

Caixeta, R.; Guimarães, C. Pela distinção entre ficção e documentário, provisoriamente. Introdução. In: ComoLli, J.-L. Ver e poder. A inocência perdida: cinema, televisão, ficção, documentário. Belo Horizonte: Editora UFMG, 2008. p. 32-49.

Comolli, J.-L. Ver e poder. A inocência perdida: cinema, televisão, ficção, documentário. Belo Horizonte: Editora UFMG, 2008.

Costa, F. C. O primeiro cinema: espetáculo, narração, domesticação. São Paulo: Scritta, 1995.

Duarte, R.; Alegria, J. Formação estética e audiovisual: um outro olhar para o cinema a partir da Educação. Revista Educação e Realidade, Porto Alegre, v. 33, n. 1, p. 59-79, 2008. Disponível em: <http://seer.ufrgs.br/index. php/educacaoerealidade/article/view/6687/4000 >. Acesso em: 10 mar. 2018.

Fischer, R. M. B. Docência, cinema e televisão: questões sobre formação ética e estética. Revista Brasileira de Educação, Rio de Janeiro: ANPed; Campinas: Autores Associados, v. 14, n. 40, p. 93-102, jan./abr. 2009. 
Disponível em: <http://www.scielo.br/pdf/rbedu/v14n40/v14n40a08.pdf>. Acesso em: 10 mar. 2018.

Gomes, C. L. Lazer, economia criativa e indústrias culturais e criativas: onde está o social? Licere, Belo Horizonte, v. 18, p. 364-387, 2015.

Gutiérrez Alea, T. Dialética do espectador. São Paulo: Summus, 1983.

L'ARRIVÉE d'un train à la Ciotat. Direção Auguste Lumière e Louis Lumière, 1895. França, 28 dez. 1895.50 seg.

Martin, M. A linguagem cinematográfica. São Paulo: Brasiliense, 1990.

Napolitano, M. Como usar o cinema na sala de aula. São Paulo: Contexto, 2003.

Rivoltella, P. C. Il cinema luogo di educazione, tra scuola ed extra-scuola. In: Malavasi, P.; Polenghi, S.; Rivoltella, P. C. Cinema, pratiche formative, educazione. Milano: Vita \& Pensiero, 2005. p. 67-88.

Sorlin, P. Esthétiques de l' audiovisuel. Paris: Éditions Nathan, 1992. 



\title{
CAPÍTULO 2
}

\section{A FOTOGRAFIA E A POLÍTICA DO BRINCAR}

\author{
Jorge Quintão
}

As crianças não brincam de brincar. Brincam de verdade.

QUINTANA, 2005, p. 805

Brincar, ainda hoje, é uma das coisas mais importantes que faço na vida. Fui uma criança que brincou muito. Explorei cada possibilidade. Sou um adulto que brinca muito - seja com minha filha, meus sobrinhos, meus alunos. Mas brinco. Quando criança, criava inúmeros projetos imaginários ou não. Planejava, desenhava, executava e, por fim, testava. Experimentava. Nem sempre tudo saía como o planejado, mas isso pouco importava. A cada projeto, eu aprendia. E a vida deve ser mesmo assim, um aprendizado constante.

Da criança que fui ao adulto que me tornei, muitas coisas não mudaram. A começar por essa "brincadeira" ininterrupta que é o projetar. Ainda crio projetos. Com objetivos muito diferentes, óbvio. Mas, ao olhar para meus projetos hoje, consigo enxergar muito dos meus projetos da infância, principalmente no que diz respeito à experimentação.

Experimentar tornou-se algo natural na minha vida, graças as minhas brincadeiras e ao meu avô, o sr. Américo, uma espécie de "Professor Pardal", que passou quase os seus 102 anos desmontando e reconstruindo coisas. Cresci ao seu lado, e foi ao seu lado também que descobri que podia consertar qualquer objeto nesta vida e ir além: é possível ressignificar o funcionamento de qualquer coisa. Com ele, entendi também que cada objeto tem uma constante universal de funcionamento e compreensão, cuja lógica é mais ou menos assim: para você entender como algo opera, basta desmontá-lo. Desmontando e montando objetos compreendemos 
o seu modus operandi e, em um segundo momento, podemos juntar outras peças e dar a eles novas funções.

$\mathrm{Na}$ minha infância, eletrodomésticos, eletroeletrônicos, motores e utensílios danificados eram muito valiosos. Tudo se transformava nos objetos dos meus sonhos. Foi nessa fase também que aprendi a observar - observar etnograficamente. Metodologia que por sinal se tornou a minha principal ferramenta de trabalho. Com ela, compreendi que nós, adultos, geralmente fazemos o mesmo que fazíamos quando criança - o que muda na verdade é a proporção.

Quem consegue associar as brincadeiras prediletas da infância a sua atividade profissional sente uma espécie de plenitude ao lidar com o trabalho. Já aqueles que não conseguem acabam desenvolvendo algum hobby muito similar a elas, ou com o mesmo princípio. Fato é que toda a minha trajetória profissional está associada ao brincar. Por aqui, brincadeira é coisa de gente grande. Coisa séria. Coisa que deve ser levada a sério. Sempre. Coisa que precisa ser registrada. Fotografada.

\section{A fotografia como técnica}

Escolher não ingressar na faculdade logo que terminei o ensino médio foi uma decisão e tanto. Mas, afinal de contas, quem tem maturidade o suficiente para fazer uma escolha tão importante aos 17, 18 anos. Naquela época, eu não sabia em qual curso gostaria de ingressar e qual profissão desejava seguir. Logo, a escolha possível para aquele momento era trabalhar. Sem nenhuma experiência profissional, meu tão almejado primeiro emprego foi como auxiliar de contabilidade. Das idas e vindas para o trabalho, amizades foram construídas, e entre elas uma em especial fez toda a diferença no meu percurso.

Nélio era um sujeito curioso, que guardava no bolso da camisa uma pequena câmera analógica, acionada sempre que o cotidiano pulsava diante de seus olhos. Com ele, descobri que, mesmo adulto, era possível ver o mundo de uma forma diferente; aliás, era possível me reconectar com aquele meu mundo - aquele mesmo da infância, no qual tudo era leve, surpreendente, inédito, curioso.

Ao vê-lo desviar o olhar do óbvio para fotografar detalhes do dia a dia, como um tênis surrado, uma formiga carregando uma folha ou cacos de vidro no asfalto, um novo mundo também saltava aos meus olhos. A maioria das fotos produzidas por Nélio era desfocada, meio borrada. Ele 
não se preocupava com o foco, com a forma, com as regras, tampouco conhecia todas as potencialidades de sua máquina fotográfica. O que lhe interessava, na verdade, era o ato de fotografar instantes. Aquela sensação instigante de se produzir imagens.

O modo como Nélio fotografava me chamava bastante atenção, justamente porque não havia um processo sofisticado de criação e execução. Para ele, fotografar era essencialmente despretensioso e, de certa forma, até um pouco lúdico. Antagonicamente, ele sentia o tão falado estalo ao observar as fotos produzidas. O estalo é aquilo que Roland Barthes descreve como a atração ou a fascinação gratuitas ao nos deparar com imagens sem necessariamente nos interrogar sobre nossa "comoção para enumerar as diferentes razões que temos para nos interessarmos por uma foto" (BARThes, 1984, p. 35). Ainda não consigo muito bem identificar a técnica que Nélio usava, apesar de entender que existia alguma ordem ali - não da maneira como eu vislumbrava, pois ele não explorava nenhum dos recursos mais potentes da fotografia, como a luz, o enquadramento, o tempo de exposição, a composição, por exemplo. Ele não estava preocupado com o observador. Ele não se preocupava com a intencionalidade da imagem e, consequentemente, com as sensações de quem porventura pudesse observar suas fotos.

Inspirado por Nélio, eu também comecei a fotografar com uma câmera simples, analógica, mas que tinha uma peculiaridade incrível: ela duplicava a quantidade de fotos produzidas por um filme, ou seja, um filme de 36 poses podia ser utilizado como um de 72 poses. Isso era incrível, quase indescritível, para ser mais preciso. Para quem estava iniciando na arte de fotografar, tal particularidade do equipamento era fenomenal - essencial -, pois otimizava o custo da produção e, assim, permitia muito mais experimentações.

Depois de muita prática, acabei trocando meu equipamento amador por um profissional e então toda a minha relação com a fotografia foi alterada. A pesquisa tornou-se constante, a base de tudo. A prática era quase diária. Todo o aprendizado era testado imediatamente. Autodidata, ia descobrindo novas técnicas e possibilidades e aprendia muito com fotógrafos consagrados. Era imitando os grandes mestres da fotografia que eu exercitava a minha técnica.

Galimberti (2006) diria que o que estava acontecendo comigo era uma espécie de "totalitarismo da técnica", em que o seu avanço é irreversível perante ideologias superadas. Não havia possibilidade de retornar 
às imagens do meu amigo e analisá-las da mesma maneira como eu as tinha visto pela primeira vez. Nesse sentido, Vilém Flusser (2002) observa que o interesse do fotógrafo "está concentrado no aparelho e o mundo só interessa em função do programa. Não está empenhado em modificar o mundo, mas em obrigar o aparelho a revelar suas potencialidades" (Flusser, 2002, p. 23). Dessa maneira, me questiono: Afinal, quem modifica quem? A técnica modifica o homem, ou o homem modifica a técnica? De certa forma, minha câmera me transformou de Homo faber a Homo ludens (Flusser, 2002). A câmera passou a funcionar de acordo com a minha intenção, e eu articulava controles para conseguir retratar e dar a forma que eu desejava. Por isso, retornando ao modo como Nélio fotografava, penso que seu ato era meramente ingênuo e suas imagens não traziam nenhum conceito. Meu amigo e sua câmera não se entendiam. Ele podia sentir determinada emoção ao fotografar, mas sua câmera não o acompanhava, pois sua técnica limitava-se apenas a apertar o botão do disparador. A meu ver, só conseguimos retratar algo pelos nossos sentimentos quando fotógrafo e câmera são uma unidade, ou seja, quando a câmera se torna uma prótese perfeita. O olho do fotógrafo passa a ser a lente da câmera. Quando atingimos certo grau de qualificação técnica, passamos a não pensar muito para produzir uma foto. Tal afirmação pode parecer contraditória, pois meu amigo também não pensava para produzir suas fotos. A diferença está no que Barthes chama de studium, ou seja, o que nos faz "encontrar as intenções do fotógrafo, entrar em harmonia com elas, aprová-las, desaprová-las, mas sempre compreendê-las, discuti-las em mim mesmo, pois a cultura [...] é um contrato feito entre os criadores e os consumidores" (BARTHES, 1984, p. 48).

Minha fotografia tinha função, ou seja, trazia um significado em si. Só entendo isso porque, ao olhar para as imagens produzidas por Nélio, percebo que, diferentemente dele, eu buscava - e ainda busco - significado nas fotos. Isso era o que eu procurava desde o princípio, porém naquele momento ainda tinha dificuldades em compreender. De certa forma, toda essa teoria sobre o significado das imagens na instância da produção parecia funcionar perfeitamente para mim naquele momento, dando conta de um percurso baseado na observação e na experimentação.

A técnica tornou-se o primor do conceito na fotografia. Alguns anos depois não imaginava que toda essa definição cairia por terra e daria lugar prioritário ao brincar. 


\section{0 brincar como técnica}

Tudo começou de maneira despretensiosa. Eu já era fotógrafo profissional, com passagens pelo fotojornalismo, pela fotografia documental, pela sala de aula em nível superior. Já possuía ampla experiência e, sobretudo, técnica. Como referência em meu campo de atuação, fui convidado, em 2008, a ministrar aulas para crianças entre 11 e 13 anos, em uma escola municipal de Belo Horizonte localizada em um dos maiores aglomerados da cidade.

Ainda não havia tido a oportunidade de ensinar fotografia para crianças, jovens e adolescentes, e isso, certamente, foi determinante para que eu aceitasse tal convite. Na primeira aula, sentia-me feliz e extremamente seguro. Entrei em sala de aula e sem demora fui contando um pouco da minha trajetória - pessoal e profissional. Da decisão de não ter entrado logo na faculdade até a conclusão do curso superior, da especialização, do mestrado. Da guinada de engenharia para letras, e de letras para a linguagem, e, de certa maneira, do retorno à engenharia, passando pela gestão de projetos e, consequentemente, pela fotografia e pelo audiovisual. Em seguida, fui abordando noções de técnica básica para iniciantes na arte de fotografar. Em menos de vinte minutos, aqueles doze pares de olhos, que no início da conversa brilhavam, já se mostravam inquietos, entediados, completamente desinteressados. A eles não interessava como funcionava a tal relação de velocidade do obturador, relacionada à abertura da lente e à distância focal. O que aqueles olhos ávidos pediam era para sair da sala de aula e experimentar.

Compreendi que a técnica era um complicador naquele momento. Para aqueles alunos, tal processo não poderia mesmo ser algo tão atraente no primeiro momento. Sem muita alternativa, me despi de toda a minha vaidade e de todas as certezas que tinha, fiz uma breve explanação sobre como manusear uma câmera e quais os comandos necessários para se fotografar, e lá fomos todos - sem técnica nenhuma - explorar ambientes até então desconhecidos pela maioria de nós. A técnica - bem, a técnica seria utilizada sempre que um jovem sentisse alguma dificuldade em produzir a imagem que desejasse. Fora isso, a descoberta e o aprendizado aconteceriam naturalmente, no tão delicioso jogo de tentativa e erro, ou seja, na brincadeira.

Diante dessa experiência, começava a ser descontruído tudo aquilo em que eu acreditava. Foi aí que teve início um processo inverso, que perpetua até hoje, no qual eu aprendo muito mais com meus alunos que 
eles comigo. Inicialmente, as saídas fotográficas eram livres, não tinham um tema definido, mas aos poucos, e com base na observação, foram implementados três eixos básicos que direcionaram a metodologia do projeto: o eu (autorretrato), o outro (retrato) e a comunidade (paisagem e objetos). Assim, a fotografia passou a ter outra utilidade dentro de um sistema de regras, do qual eu não fazia parte. Era a primeira vez que eu ia fotografar pelos olhos dos outros.

Enquanto meus alunos fotografavam a comunidade em que viviam, exploravam cada beco, retratavam cada morador, o dia a dia do comércio e a vida na favela, eu os fotografava. Contudo, nesse processo eu não queria sentir o que já havia sentido em outras ocasiões, quando trabalhei como fotógrafo documentarista em várias regiões do país nas quais os Índices de Desenvolvimento Humano (IDH) eram extremamente baixos e eu me sentia como um ladrão, que retirava algo daqueles lugares e nunca devolvia nada, efetivamente, aos moradores.

Com essa percepção, achei que aquela seria a oportunidade de fazer com que os moradores da comunidade, pelo ponto de vista dos meus alunos, que também residiam ali, contassem suas próprias histórias por meio da fotografia.

As aulas acabaram tornando-se um projeto - o Imaginário Coletivo -, no qual pude notar de imediato que os jovens tinham dificuldade em perceber a si próprios e as suas imagens no local onde viviam, querendo ser quem eles não eram, retratando-se como não eram. Isso ficava bastante claro nas conversas sobre como eles viam a própria realidade e nas ilustrações que produziam.

Essa percepção ajudou a formatar as propostas das saídas fotográficas para que os alunos pudessem compreender a importância do olhar para aquela realidade, sem preconceitos ou associações com imagens midiáticas. A ideia era promover um descondicionamento do olhar, lançando mão de uma visão mais crítica, sem medo de mostrar a verdade ou sem interesses pessoais.

Foram propostas saídas em grupos, com cada jovem retratando como quisesse o que considerava importante na comunidade, sempre com base no tema da aula. Nesses momentos, foi possível trabalhar qualidades como liderança, capacidade de trabalho em grupo, proatividade, criatividade, organização, planejamento, entre outros. Todas as atividades eram desenvolvidas de forma lúdica, sem necessariamente que os alunos tivessem consciência disso. 
Nesse sentido e dentro de um grupo que cultivava o respeito ao outro, cada criança passou a se sentir valorizada por suas qualidades pessoais, tendo a oportunidade de aprender, por meio da fotografia e da arte, a exercitar a sua própria criatividade. Foi possível perceber uma melhora na autoestima dos jovens. Fazendo uso da imaginação, a criança podia criar outra visão daquele mundo em que vivia, trazendo esperança e desenvolvendo habilidades até então desconhecidas. $\mathrm{O}$ ponto de vista, nesse sentido, passava a ser o deles, e não o meu. Isso me trouxe grande alívio, pois as imagens produzidas não eram minhas, mas dos próprios moradores. Com isso a técnica fotográfica era pouco a pouco dominada, dado que era exercitada na experimentação das brincadeiras, na tentativa, no acerto e no erro. A fotografia passou a ser mais uma possibilidade de linguagem dentro daquela comunidade.

Compreendi também que a invisibilidade, tão característica de uma parcela da população que vive às margens da sociedade, passava a ter uma função. $\mathrm{O}$ fotógrafo precisa ser invisível para retratar uma cultura sem interferir minimamente em seu funcionamento. Assim, o jovem ali utilizava sua invisibilidade para produzir as fotografias. Com a possibilidade da experimentação, cada um tinha a chance de vivenciar situações para fotografar e, desse modo, passava a ter afinidade com algum tipo de técnica. Surgiram especialistas dentro do projeto: jovens que produziam retratos belíssimos, paisagens maravilhosas, fotografias panorâmicas, ou artistas especializados em temas específicos ou em séries fotográficas, retratando detalhes da comunidade até então despercebidos. Eles passaram a se identificar com os conteúdos e tiveram a oportunidade de aprimorar cada vez mais a sua técnica. Em fotografia, geralmente os mais tímidos preferem fotografar paisagens, e os mais desenvoltos tornam-se retratistas, pois têm a facilidade de interação com as pessoas e criam, prontamente, vínculos emocionais para a produção de retratos. Os perfis fotográficos surgem com naturalidade, como consequência do desejo do fotógrafo.

Pode parecer uma coisa simples, mas quando se decide o que quer, quando e como quer, passa-se a ter o poder de decisão, algo tão precioso para a faixa etária com a qual trabalho. E, em fotografia, decidir o que se quer registrar é um fator determinante. Ter autonomia para decidir faz com que a criança ou o jovem adquira autoconfiança no que está fazendo. Junte a isso a possibilidade de trabalhar de forma crítica, para adquirir consciência do que está retratando, e teremos uma equação poderosa 
para mudar a percepção de indivíduos sobre sua realidade. Essa forma de empoderamento, silenciosa, transforma realidades.

\section{0 jovem e a relação de poder}

Quando pensamos em favela, imediatamente surgem em nossa mente imagens de pobreza, violência, tráfico de drogas, comportamentos marginalizados e falta de infraestrutura. Tal imagem, construída ao longo dos tempos pela sociedade, muitas vezes não condiz com a realidade. Pelo fato de o Estado não se fazer presente como meio de controle, nessas comunidades alguns padrões podem não seguir as mesmas regras da sociedade organizada. Um exemplo disso é a arquitetura desordenada que se estrutura nesses espaços.

Em alguns lugares da comunidade na qual o projeto acontecia, não havia ruas, mas apenas becos, e as construções tinham sido levantadas de acordo com a necessidade e conveniência dos moradores. Ali, relações e normas não eram aplicadas. As pessoas pareciam estar confinadas em uma espécie de bolha social, mesmo rodeadas por bairros nobres e urbanizados. As oportunidades de trabalho não chegavam ali, mas, ironicamente, dali saía mão de obra qualificada, que atendia os bairros ilustres que circundavam a região.

Um fator interessante que deve ser considerado nesta análise é o papel da escola nessa comunidade especificamente, uma vez que era realizado em parceria com uma escola municipal.

Com controle de horários e atividades, a escola promove o condicionamento do indivíduo ao meio. Tal controle é necessário muitas vezes porque a estrutura familiar em que o sujeito se encontra não dá o suporte necessário para que ele se desenvolva como o indivíduo que o Estado espera que ele seja. A disciplina tem a função de criar uma submissão que Foucault (2009) chama de corpo "dócil”, organizando e pondo ordem dentro de um espaço físico delimitado pelas grades e muros da escola, e não em um sistema como um todo. Ao mesmo tempo, as atividades e a disciplina delimitam espaços. A criança passa a ter necessidade de comportar-se de maneira diferente em cada ambiente que frequenta. $\mathrm{Na}$ escola, ela está sob sérias regras de convivência, muitas vezes diferentes das que encontra em seu lar.

$\mathrm{Na}$ escola parceira do projeto, alunos de 6 a 13 anos eram conduzidos nesse regime para serem transformados e disciplinados dentro dos limites da comunidade. Dessa maneira, o espaço escolar acabava ficando 
presente na vida dos alunos e configurando-se como parte necessária ao seu desenvolvimento. Ali as crianças tinham atividades em horário integral e eram submetidas a aulas regulares na parte da manhã ou da tarde. $\mathrm{Na}$ outra metade do tempo, elas podiam escolher participar de outras atividades, como aulas de capoeira, de xadrez, balé, de esportes diversos, entre outros, e aulas de fotografia. As aulas eram ministradas sempre dentro da comunidade, em espaços específicos para cada atividade ou na rua, a céu aberto. As crianças mantinham contato entre si todos os dias úteis da semana, além de estarem sob o olhar atento de vizinhos e familiares. Aos fins de semana, na hora de realizar brincadeiras, meninos e meninas procuravam os colegas, que naquela comunidade muitas vezes eram os próprios vizinhos. Dessa maneira, as crianças acabavam criando um mundo em que mantinham contato quase diário com os colegas, estreitando as relações, pois a comunidade, por sua vez, permitia que pais, vizinhos e crianças estivessem em contato durante as atividades educativas. As ruas estavam sempre cheias de pessoas que observavam atentamente cada passo de quem por ali circulava. E isso não era diferente em relação à escola, sendo observados nos momentos de saída as crianças e o comportamento dos professores. Tal vigilância estabelecida pela comunidade e pelos moradores, que tudo observam para manter a "ordem", parece ir ao encontro do conceito do que Foucault descreve como Panopticon ${ }^{1}$. As atividades, antes na "escuridão" das salas de aula, agora estavam à mostra daqueles que detinham o poder de controle. A própria comunidade observava as atividades do projeto, realizadas ao ar livre, à luz do dia. É interessante observar que ali a inversão de papéis de poder, antes exercido pelo Estado, estava na mão de uma minoria que observava para controlar o andamento das atividades da escola. Tal imagem é muito diferente do que se observa nos noticiários das grandes redes de TV, que insistem em noticiar tragédias advindas das periferias como se isso fosse uma regra.

As imagens de espaços urbanos de comunidades, principalmente os veiculados pela mídia, são carregadas de uma aura de insegurança,

1 Construção periférica dividida em celas, cada uma ocupando toda a largura do prédio, que é na forma de U. "Essas celas têm duas janelas: uma abrindo para o interior, correspondendo às janelas da torre; outra, dando para o exterior, permite que a luz atravesse a cela de um lado a outro. [...] Devido ao efeito de contraluz, pode-se perceber da torre, recortando-se na luminosidade, as pequenas silhuetas prisioneiras nas celas da periferia. Em suma, inverte-se o princípio da masmorra; a luz e o olhar de um vigia captam melhor que o escuro que, no fundo, protegia" (Foucault, 2005, p. 210). 
de pobreza, de medo, de injustiça. Entretanto, ao entrar na realidade do morro, pode-se perceber que não é muito bem isso que acontece. As ruas lembram as pequenas cidades do interior de Minas, nas quais os visitantes são sempre bem-vindos. Para se ter acesso aos moradores de uma forma mais intimista, é necessário conquistá-los, demonstrar que você é uma pessoa de bem e que está ali para somar, e não para extrair informações ou imagens, como se retirasse um pedaço de uma cultura para levar como souvenir. As relações são mais verdadeiras e próximas, prevalecendo ainda a confiança pela palavra e pela honra.

Apesar das relações verdadeiras, os problemas sociais e de violência existem, mas mesmo assim o local parece outro mundo. Um mundo dentro de outro. De certa maneira, quando se entra no aglomerado e se observa esse espaço pela primeira vez, é natural que o medo do desconhecido tome conta. As imagens que estamos acostumados a associar a essas realidades não nos deixam confortáveis. Se nos colocássemos no lugar de um fotojornalista, que estivesse dentro de uma favela, poderíamos produzir imagens do descaso, da pobreza, do tráfico de drogas, do esgoto a céu aberto. Mas, quando deslocamos nosso ponto de vista para o olhar de uma criança que vive nesse espaço, a tarefa de fotografar parece mais adequada, pois essa criança é parte integrante da comunidade e, de certa maneira, ainda têm uma visão mais inocente desse universo. Seria como uma visão autêntica do local (se é que ela existe) e sem os "vícios de imagem" preconceituosos ou do olhar condicionado de uma sociedade elitista que mora do outro lado da avenida, que então divide os dois mundos.

Nesse sentido é que o projeto fotográfico contribuiu para que indivíduos pudessem perceber outras formas de expressão e, assim, aprender a valorizar suas qualidades e sua cultura.

É ver a comunidade pelos olhos de uma criança.

Nesse processo, percebi que alguns alunos eram capazes de produzir imagens críticas do espaço em que viviam com uma maturidade espantosa, digna de quem precisa ser mais maduro por questão de sobrevivência.

Selecionei então a produção de um dos alunos para exemplificar as atividades lúdicas desenvolvidas pelo projeto fotográfico.

Maurício ${ }^{2}$ tinha 12 anos, era um garoto tímido, disciplinado e gostava muito de animais. Seu sonho era ser biólogo e fotógrafo de natureza. Morava em uma área mais afastada da escola com a mãe e os irmãos.

2 O nome do aluno é fictício, para preservar sua identidade. 
Logo nas primeiras aulas práticas do projeto, Maurício destacou-se pela forma inusitada como fotografava, procurando ângulos diferentes da maioria dos outros alunos e por possuir um senso crítico apurado, algumas vezes transgredindo as regras estipuladas para fotografar pessoas e objetos na comunidade.

Nas aulas práticas, os alunos eram orientados a solicitar permissão verbal das pessoas antes de produzir um retrato. Logo de início, percebi que Maurício criava alternativas para burlar a regra e, mesmo sem autorização, fotografar um morador da comunidade que não queria aparecer em suas imagens. Além disso, Maurício não gostava de produzir fotos de pessoas que posavam. Ele é quem decidia como a foto deveria ser feita e como o fotografado devia se portar. Aqueles que posavam como queriam tinham a cabeça cortada pelo fotograma (Imagem 1), exibindo somente o tronco, ou, ainda, tinham a sua imagem borrada intencionalmente, desfigurando a pessoa retratada (Imagem 2).

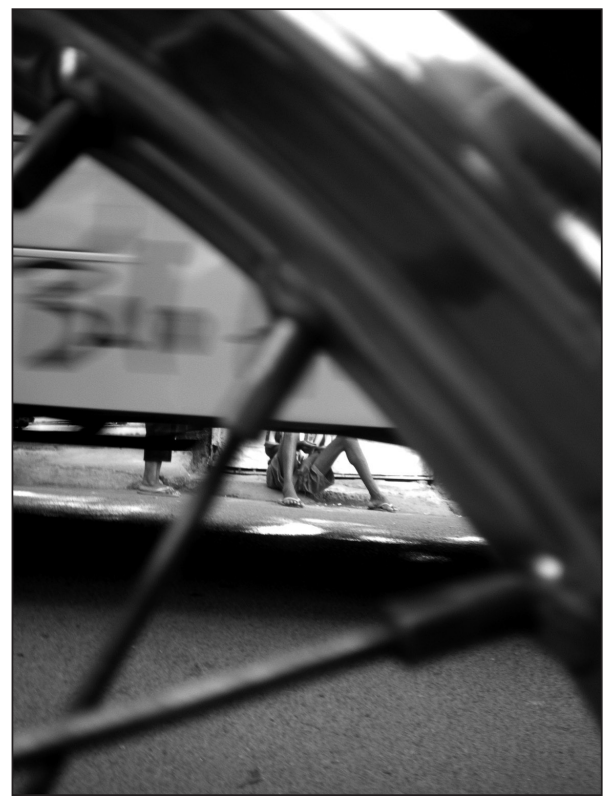

Imagem 1

Fonte: Acervo pessoal/material didático.

As imagens eram produzidas de maneira consciente por Maurício, que estabelecia uma relação de poder entre ele e o fotografado. As poses, geralmente feitas por meninas, remetiam a alguma artista da TV de 
quem Maurício dizia não gostar e com isso, para não contrariar a modelo, ele fazia a foto, mas do seu jeito (Imagem 2).

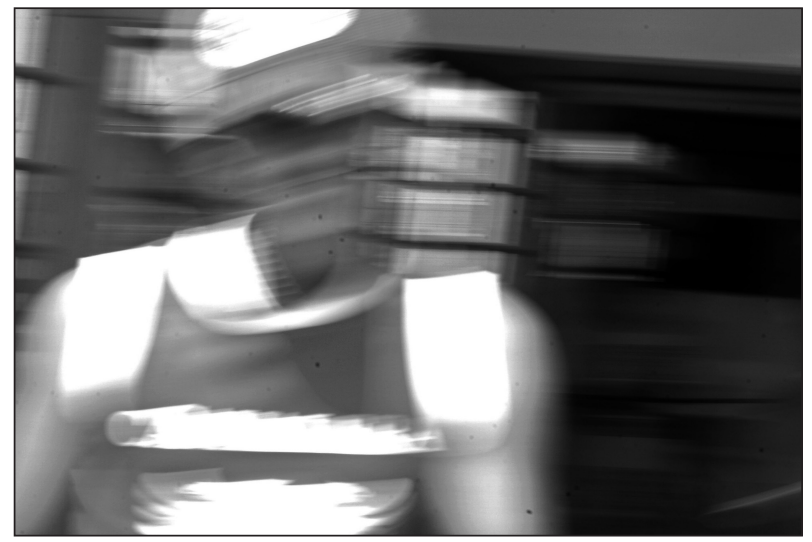

Imagem 2

Fonte: Acervo pessoal/material didático.

Maurício utilizava a câmera para expressar seus desejos sem que o fizesse de forma direta, lúdica. A câmera passara a funcionar sob sua intenção, e ele articulava controles para conseguir retratar o que desejava e da forma como desejava. Por meio da fotografia, ele podia se expressar e ter o controle da situação. Podia ter poder sobre o seu espaço e sobre as pessoas retratadas. Os seus modelos tornavam-se corpos dóceis, que podiam, pela articulação da imagem, e consequentemente da técnica, serem manipuladas conforme seu desejo.

Assim, “ao decidir que velocidade será usada na hora do 'clic', ou seja, no exato momento da 'captura' do objeto a ser fotografado, o fotógrafo o faz baseado em seus pressupostos teóricos" (CAPUTO, 2001, p. 6).

A técnica não tinha unicamente uma função estética, mas sim política. Maurício tinha o domínio da situação e o poder para decidir em suas mãos, como nunca antes experienciado.

Tal possibilidade o levou a ir além da proposta apresentada durante as aulas. A criatividade passou a ser outro elemento para a composição e para a articulação dos seus desejos. O jovem fotógrafo passou a utilizar objetos encontrados nas ruas e nos becos da comunidade para compor suas fotografias. Potes vazios de iogurte, moedas, cédulas e até mesmo o grafite estampado em uma parede, tudo, ou quase tudo, era usado para integrar suas imagens. Até os dedos (Imagem 3) eram utilizados como elemento de intervenção nas fotos, direcionando o olhar do espectador para determinado ponto na imagem. 


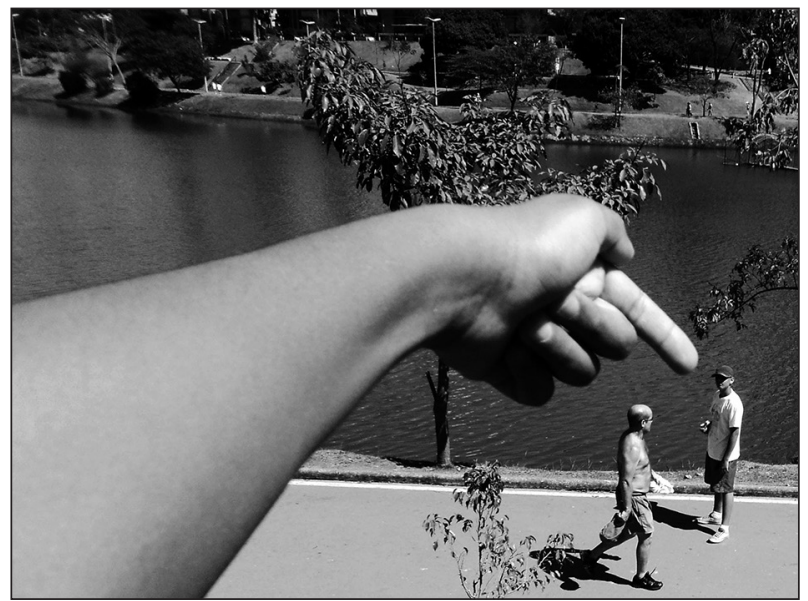

Imagem 3

Fonte: Acervo pessoal/material didático.

Na maioria das vezes, Maurício produzia suas imagens, mas em outras ocasiões dirigia a cena, composta de outros alunos, integrantes do projeto. $\mathrm{Na}$ brincadeira, apesar de tímido, exercia a liderança, a organização e o compartilhamento de informações com os colegas. Para o garoto, o fotografar passara a ser muito mais que apertar o disparador da câmera.

Como dito inicialmente, quando fotógrafo e câmera são uma unidade, ou seja, quando a câmera se torna uma prótese perfeita, o olho do fotógrafo passa a ser a lente da câmera. Além disso, quando se atinge certo grau de qualificação técnica, passa-se a não pensar mais para produzir o efeito desejado para a foto. O olhar torna-se registrável. O fotógrafo sabe que a foto é boa ou é ruim, porque tem a consciência de que, pela técnica, o objetivo final foi atingido ou não.

$\mathrm{Na}$ fotografia não existe certo e errado. O que existe é a intenção do fotógrafo. Se ela for a de borrar uma imagem ou desfigurar um retrato, para produzir um efeito consciente, a imagem está certa. Pode ser que para um observador a imagem borrada esteja tecnicamente equivocada, mas para o fotógrafo ela está certa, porque é a intenção é que dita o certo e o errado.

Foi assim que Maurício conseguiu perceber o espaço em que se encontrava, compreendendo-o, tendo o controle da técnica, podendo produzir a sua imagem crítica por meio de seu protagonismo.

A fotografia de Maurício tinha função, ou seja, trazia um significado em si, ao contrário da fotografia de alguns outros alunos, que 
simplesmente apertavam o disparador da câmera. O garoto, com 12 anos, podia, dentro de um sistema de poderes que regulava seu comportamento a todo o tempo, ditava sua forma de viver e sua condição social, ser ele mesmo, quando quisesse, bastando olhar através do visor da câmera e apertar o disparador.

Como fotógrafo, pude descobrir que havia outras possibilidades a serem exploradas enquanto produtor de imagens. Como educador, me senti absolutamente realizado, uma vez que o projeto permitiu diversos desdobramentos na percepção dos jovens integrantes.

Com o passar do tempo, foi possível propor vários tipos de atividades, deixando câmeras com os alunos para que fotografassem sua casa. Além disso, passamos a realizar atividades fora da comunidade, em espaços públicos da cidade, nos associamos a outros projetos, com outras iniciativas, tais como sugestões de oficinas de literatura e fotografia, entre outras propostas.

De forma geral, nas saídas fotográficas a organização era feita pelos próprios alunos. Eles é quem decidiam aonde ir e o que fotografar. A autonomia era progressivamente dada a eles, à medida que passavam a compreender o papel social de cada um dentro do grupo. É assim que a sensação de orgulho e satisfação toma conta dos sujeitos. Aos poucos os jovens fotógrafos conquistavam a condição de poder sair sozinhos para fotografar. Confiar a esses jovens a responsabilidade pelo equipamento é lhes dar a oportunidade de ir e voltar, em um tempo predeterminado, tornando-os aptos a serem autônomos no processo de atividades do projeto. É dividir a responsabilidade na produção das imagens e na proposta do projeto. Assim ele se torna parte do todo, tendo consciência de que, por exemplo, o zelo pelo equipamento é fundamental para que ele e outros colegas possam ter a chance de brincar e ao mesmo tempo produzir as imagens. Com isso, há um aumento significativo na autoestima do indivíduo e nas possibilidades criativas, uma vez que ele passa a sofrer cada vez menos interferência hierárquica de poder, pois têm autonomia para decidir, em várias instâncias, seja no exato momento da produção da imagem ou na organização social das saídas fotográficas. O sujeito aprende a decidir dentro de um grupo e a compreender que nem sempre a sua escolha é a melhor para todos, mas a aceita. Surge aí também o poder de articulação de propostas, baseadas em perdas e ganhos. Um dia o grupo aceita a sugestão de um jovem e, em outro, pode aceitar a proposta de outro. $\mathrm{O}$ consenso surge na compreensão do objetivo do projeto: o de fotografar brincando. 
Tomando como base essa percepção, tive a oportunidade de atuar além da sala de aula, propondo ações para a comunidade, com o foco na valorização dos moradores. Assim as atividades passaram a ser propostas de forma cíclica, isto é, ao fim de cada processo, ou oficina, uma exposição seria apresentada aos moradores. Assim havia a oportunidade de devolver as imagens produzidas para os moradores, como um todo, ampliando ainda mais a conexão afetiva.

Para fortalecer os laços identitários nas comunidades, escolhi o retrato ${ }^{3}$ como principal tema das exposições fotográficas. Para isso foram adotadas fotografias em grandes formatos, de três a cinco metros de altura, para serem exibidas, fossem penduradas em locais de grande circulação ou coladas em espaços estratégicos na comunidade.

Entendo que as fotografias em grande formato e reproduzidas em papel são perecíveis ao tempo, bem como a imagem dos moradores de uma favela. Assim, era preciso renovar a exposição, fazendo com que as imagens estivessem sempre visíveis, como reafirmação da presença de pessoas residentes das comunidades. Era uma forma de devolver as imagens retiradas e valorizar quem vivia naquele espaço.

Houve nesse trabalho um contraponto com a imagem do morador da favela, uma vez que as fotos em grande formato eram coladas nas fachadas das casas e podiam ser avistadas a longa distância, evidenciando a presença de pessoas naquele local. A longa distância não é possível avistar o morador da favela, mas as fotos, sim.

O projeto segue a sua proposta, dando voz a jovens com a promoção do conhecimento, do respeito ao outro, da contemplação e da reflexão, sempre usando a linguagem fotográfica e a brincadeira.

Há um mês tive notícias de Maurício. Agora um rapaz, casado, trabalha em uma farmácia e estuda à noite. Ele cursa biologia e o sonho de ser fotógrafo de natureza está mais vivo do que nunca.

3 Em termos técnicos de fotografia, retrato é a representação da imagem de uma pessoa, geralmente com as características de uma foto $3 \times 4$, que mostra cabeça e tronco, com corte na altura do peito. Normalmente, uma imagem posada tem certa cumplicidade com o fotógrafo. Em uma apropriação popular, retrato é qualquer foto que tenha gente. No nosso caso, é a foto de uma pessoa somente, que faz parte de uma das propostas do projeto: o eu (a selfie), o outro (fotografia de retrato) e a comunidade (fotografia de paisagem). 
E eu sigo a minha proposta, com uma alegria que não cabe no peito e a certeza de que o caminho, apesar de tortuoso, pode levar nossos jovens para onde eles quiserem ir, afinal o brincar transforma vidas.

\section{Referências}

BARthes, R. A câmara clara: nota sobre fotografia. Rio de Janeiro: Nova Fronteira, 1984.

Caputo, S. G. Fotografia e pesquisa em diálogo sobre o olhar e a construção do objeto. Teias, Rio de Janeiro, ano 2, n. 4, p. 1-10, jul./dez. 2001.

Flusser, V. Filosofia da caixa preta. Ensaios para uma futura filosofia da fotografia. Rio de Janeiro: Relume Dumará, 2002.

Foucault, M. Microfísica do poder. São Paulo: Graal, 2005.

Foucault, M. Vigiar e punir. Rio de Janeiro: Vozes, 2009.

Galimberti, U. Psique e techne. São Paulo: Paulus, 2006.

Quintana, M. Poesia completa. Rio de Janeiro: Editora Nova Aguilar, 2005. 


\title{
CAPÍTULO 3
}

\section{A EXPERIÊNCIA DE BRINCADEIRA}

\author{
Eugênio Tadeu Pereira
}

Há algo no ser humano que o leva ao jogo. Desde criança trazemos conosco esse impulso, e as pessoas do nosso entorno nos convidam a entrar nessa atmosfera que difere daquela das interações cotidianas. Nesse espaço relacional, algo acontece que nos vincula com aquele que entramos em contato. Estabelecemos um pacto ficcional, da mesma maneira que Umberto Eco (1989) descreve sobre a atitude do leitor diante do livro que está lendo.

Em muitas áreas do conhecimento humano, esse tema sempre esteve presente. $\mathrm{O}$ que farei aqui não é uma revisão bibliográfica nem uma nova tese sobre o tema. As bibliotecas físicas e digitais das universidades e a internet trazem essa infinidade de livros, artigos, vídeos, CDs e outros suportes que refletem sobre a brincadeira, descrevendo jogos para que os interessados possam se apropriar desses conteúdos e compartilhá-los ou não.

Começando por seu sentido psicológico, passando pelo social, pela arte, pela educação, pelos estudos sobre o lazer, pela tecnologia, pela economia e pela antropologia, a temática do brincar tem muitas vertentes. Há uma extensa bibliografia que aborda diferentes leituras sobre a prática da brincadeira.

Nas palavras que se seguem, pretendo refletir acerca das brincadeiras na perspectiva de suas mais genuínas características, tão bem apontadas por John Huizinga (1993) e Roger Caillois (2017). Esses dois pilares nos estudos sobre jogos, desde a década de 1930, são referências na forma de ver a brincadeira segundo alguns atributos que a torna como tal. Os aspectos que os autores descrevem já foram relatados e difundidos de maneira inequívoca. Mesmo assim, é sempre bom lembrarmos essas características, pois elas nos dão base para que possamos mostrar e tecer 
nossos modos de ver, compreender e refletir sobre esse fenômeno cultural que chamamos de jogo ou de brincadeira.

Aqui não farei distinção entre os termos jogo e brincadeira, como faz, por exemplo, Bruno Bettelheim (1988). Para esse autor, o jogo é dotado de regras mais rígidas, e a brincadeira, de regras mais brandas. $\mathrm{Na}$ língua portuguesa brasileira, esses dois termos se confundem, mas não vejo problema nisso. Para mim, ambos podem ser a mesma coisa, mas podem também trazer significados diferentes. Isso vai depender da história de vida de quem vai usar essas expressões e o ponto de vista escolhido para fazer a reflexão ou praticar essa atividade. Nesse sentido, Brougère (1998), Kishimoto (1998) e Pereira (2015) apontaram sobre o uso da palavra jogo como sendo consequência de nossas experiências anteriores no decorrer da vida. Na relação com o outro aprendemos a nomear as vivências de jogo ou de brincadeira. $\mathrm{O}$ contexto, as relações e o modo como lidamos com essas circunstâncias é que nos vão proporcionar essa nomeação. Porém, no que se refere aos estudos dessa modalidade de fazer cultural, é necessário apontar por qual perspectiva estamos usando essas palavras.

Dito isso, cabe-me retomar àquilo que Huizinga (1993) e Caillois (2017) traçam como elementos do jogo e que o distingue das atividades do dia a dia. Para esses autores, quem joga o faz de modo volitivo. Não se brinca por opressão ou por obrigação. Pode-se até jogar como meio de escape de uma situação conflituosa, mas ir em direção à brincadeira é um ato de puro desejo. $\mathrm{O}$ jogo acontece em determinado tempo e delimitado espaço. Os limites temporais e espaciais são marcos que separam o lugar do jogo do lugar da vida cotidiana. Se nos deparamos com alguém não sabedor dessa limitação, provavelmente a identificamos com algum traço de anormalidade. Huizinga chamou esse limite de temenos, palavra de origem grega que designa um lugar onde acontecem coisas extraordinárias dentro de sua circunscrição. O jogo ocorre guiado por regras. Não há uma brincadeira sequer que não tenha alguma norma, combinada entre os jogadores, que deva ser seguida e, muitas vezes, até burlada. No ato de jogar não há um produto a ser feito. Não há a intenção de fazer algo nesse sentido, pois a gratuidade impera nesse fazer. Ele é destituído de interesse material. O jogo acontece em uma esfera ficcional, transcende a realidade cotidiana. Isso lhe dá uma importante condição de existência, pois, valendo-se dessa ficção, o jogador poderá jogar o jogo quantas vezes quiser. Pode-se brincar de "morto e vivo" milhões de vezes, e nesse brincar não 
se morre de verdade. Os exemplos são muitos, basta observarmos do que já brincamos e do que as crianças brincam. Por fim, o jogo é imprevisível, uma vez que não sabemos o seu resultado. No jogo não temos nenhuma certeza. Ele não oferece segurança de acertos ou de finalização conhecidos previamente. Se há um resultado preestabelecido, isso não é jogo. Talvez seja alguma atividade dinâmica, mas jamais uma brincadeira. De mais a mais, não se sabe de antemão o que acontecerá no decorrer do jogo. Como já apontava Brougère (1998), a brincadeira acontece por uma contínua tomada de pequenas decisões que são executadas de acordo com as circunstâncias durante esse acontecimento.

Além dessas características, podemos observar nos jogos alguns outros aspectos que lhes são peculiares, tais como: a inventividade, o improviso, o vínculo, a interação, o risco, a tensão e o protagonismo. Todo jogo carrega algo de invenção - ele já é, por si, um invento. Ele exige do jogador combinar elementos para descobrir as saídas dos entraves e criar novos elementos na atividade. Mesmo com as regras dadas, há um caráter improvisacional que está presente no jogo: os jogadores inventam estratégias para continuarem no jogo. $\mathrm{Na}$ brincadeira, são criados vínculos, ainda que temporários. Até mesmo em um jogo de competição, a conexão com o outro é necessária. É preciso estabelecer vínculos com o adversário, pois sem os elos o jogo não acontece. Nesse sentido, toda brincadeira é um campo de interações, sejam colaborativas, imitativas ou competitivas. As relações entre os jogadores primam por um grau de interação que é necessário para esse acontecimento. Na brincadeira corremos riscos, temos desafios e há tensão. O jogo não é sinônimo de prazer nem de alegria somente. Na brincadeira de monstro com as crianças pequenas, por exemplo, o medo é estampado no rosto, mas, ao mesmo tempo, há um querer sentir esse medo. A brincadeira ativa algo do nosso mais profundo ser. Nisso, enfrentamos nossas fraquezas, para nos fortalecer diante de outros medos, seja no campo do imaginário ou na realidade do dia a dia. Isso não quer dizer que sairemos resolvidos, mas teremos a chance de encarar as situações de outra maneira. Por último, no jogo, cada pessoa se torna protagonista da ação; cada um, à sua maneira, entra no jogo e é um agente imprescindível para que a brincadeira aconteça. $\mathrm{O}$ jogo não tem existência própria.

Diante dessas breves explanações, cabe-me igualmente relembrar as categorias tão bem observadas por Caillois (2017) a respeito do que acontece no interior dos jogos. Nas mais variadas brincadeiras, Caillois 
percebeu alguns componentes que se assemelhavam e criavam determinados efeitos tanto na percepção como na condução das atividades. $\mathrm{O}$ autor nomeou de agón os jogos que têm como característica evidente a disputa, a competição e a luta. Vemos nos jogos de pega-pega, principalmente, essa característica bem estampada. Há uns sem-números dessa modalidade de jogo. Como se pode notar, jamais entramos em algum jogo no qual não seja exigido qualquer desafio. O jogo fácil não nos atrai, pois ele não tem graça. Por outra perspectiva, o autor notou que há aqueles jogos que prezam pela fantasia de ser o outro, de imitação e de simulacros. A essa categoria Caillois denominou de mimicry. As brincadeiras de casinha, aulinha, carrinho, entre outras, nos fazem reconhecer essa categoria. Podemos reparar que há jogos de sorte (ou azar) como o cerne de sua execução. A esse tipo de categoria Caillois chamou de aléa. $\mathrm{O}$ aleatório tem primazia no funcionamento dessa modalidade de jogo. Como exemplos, cito o "par ou ímpar" ou as brincadeiras de escolha para selecionar jogadores ou para ver quem ocupa determinada função em um jogo. Embora elas tenham um aspecto agonístico, trazem também uma forte dose de incerteza e de desconhecido. Finalmente, como quarta categoria, o autor nomeou de ilinx aqueles jogos nos quais o jogador sente vertigem, tonturas e deslocamentos na percepção. Os parques de diversões, o pular corda, o rodopiar são exemplos bastante claros dessa categoria.

Se olharmos os jogos mais de perto, podemos ver outra categoria além daquelas que Caillois apontou. Observo há algum tempo que existem jogos que são dirigidos especificamente para o uso do intelecto, da cognição e da capacidade mental. A essa qualidade de relação presente nesses jogos nomeio de aenigma. Nesse contexto, podemos encontrar as adivinhas, os jogos de descobrir palavras, os trava-línguas e toda sorte de brincadeiras que têm o uso das faculdades mentais com predominância.

É claro que não há uma categoria que se apresente sozinha na brincadeira. Elas se misturam. Ora uma é trazida à baila, ora outra. Logo adiante, essas categorias serão retomadas, pois elas nos dão pistas sobre o porquê temos interesse nos jogos.

Por outra perspectiva, mas não contraditória, o ser humano tem a potencialidade e a capacidade de ressignificar a realidade. Friedrich Schiller (1992) nos mostrou que está presente no ser humano, de um lado, o impulso sensível, no qual impera a variabilidade, o disforme e o acaso, e, de outro, o impulso formal, que preza pela invariabilidade, pela 
estruturação e pela organização. Do atrito entre esses dois impulsos nasce o impulso lúdico. Este dá forma à matéria e realidade à forma. O impulso lúdico seria, então, a configuração de dado acontecimento. Pensando assim, a brincadeira seria a materialização desse impulso. Ela é o impulso lúdico estruturado e configurado no interior de um temenos.

Diante dessa exposição, com a qual busco delimitar o modo que tenho visto as brincadeiras, passo a pensar um pouco sobre o modo como vamos ao encontro dessas atividades e o que está nelas que nos chama atenção a ponto de mergulharmos nesse universo. Tomando como referência Huizinga (1993), Caillois (2017) e Schiller (1992), podemos deduzir que o sentido de brincar é inerente ao ser humano, mas ele é alimentado pelas relações estabelecidas entre as pessoas desde tenra idade. Com certeza, onde há ser humano, há brincadeiras. Mas como elas se instauram? É sobre isso que vamos refletir a partir de agora.

\section{0 que nos move em direção às brincadeiras?}

No que venho observando, o sentido da presença da brincadeira na vida das pessoas está relacionado à busca de experimentar a realidade por outro ponto de vista. Brincamos porque não damos conta de como a realidade cotidiana se nos apresenta. Embora sejamos corresponsáveis por essa realidade, há fatores que não estão sob "nosso controle". Necessitamos de algo que nos tire da rotina e não precise de explicação para acontecer, mas que nos proporcione certas sensações que não teríamos de outra maneira. Ao brincarmos, entramos em contato com diversas camadas de nosso ser, mas isso não tem a ver com o místico ou com algo da ordem do irreal. A meu ver, buscamos na brincadeira aquilo que Caillois percebeu ao categorizar os jogos. Sendo assim, propomo-nos a praticá-la com o intuito de viver essas sensações. O nome do jogo tem importância na medida em que ele nos leva a experimentar essas sensações. Assim, o nome "pular corda" em si não é o mais importante, mas o que ele representa e a que ele nos remete é que vai ter sentido. $\mathrm{O}$ que acontece no momento dessa brincadeira é que nos atrai para executá-la. É claro que, ao nomearmos algum jogo, esse ato conota algum significado também. Portanto, as inúmeras variantes dos jogos que têm a vertigem como preponderância de percepção somente têm importância para o jogador porque elas o levam a uma alteração no modo de ver as coisas, variando, de alguma maneira, a sua consciência. Rodar, virar de 
ponta-cabeça pode estar em diferentes maneiras de brincar e ser o pano de fundo para viver a sensação de estar um pouco fora de si. Nos parques de diversão, isso é explícito. Ademais, o estar "desequilibrado" é um jeito de correr risco de maneira consciente. Vamos ao encontro dessa possibilidade pelo desejo de assim nos perceber. Para mim, esse é um dado importante, pois me leva a pensar nas composições da brincadeira, ou seja, a sua estrutura é urdida para proporcionar essas sensações.

Se em cada brincadeira há uma especificidade de comportamento e de sensações, podemos inferir que a estrutura e os modos de brincar despertam algo em cada jogador enquanto ele joga. A busca pela vertigem, pela disputa, pela incerteza, pelo simulacro e pelos desafios cognitivos são molas propulsoras para entrar na brincadeira. Somente nos atrevemos a entrar nesse universo se percebermos que aquela atividade nos dará algum tipo de sensação que vai nos deslocar de certa realidade.

Na brincadeira, o jogador vai ao encontro do agón para descobrir seus potenciais e compará-los aos dos outros. Ele entra na disputa para conquistar um espaço ou um reconhecimento diante de seus pares. Ganhar ou perder faz parte da situação, e lidar com essas forças é condição importante, pois assim lidamos com a frustração da perda e com a alegria do sucesso. Apostamos em nós mesmos quando queremos competir com alguém. É bom lembrar que esse alguém é um adversário, não um inimigo. Portanto, na disputa temos parceiros contrários aos nossos interesses, mas eles são condição básica para que o jogo aconteça, ou seja, o adversário é uma oportunidade para a interação e para o crescimento como pessoa ou aprimoramento técnico.

No que diz respeito à categoria mimicry, levamos em consideração o ser aquilo que não somos. Fantasiar-nos de algum ser que não sejamos nós mesmos nos possibilita tocar na dimensão do que seja o outro. Mesmo na tentativa de ser algo que eu não sou, tudo de mim permanece naquele que imito, quer queira ou não. Essa capacidade de arremedar funciona como um espelho daquilo que somos.

Lançar-se à sorte no jogo é um risco prazeroso. A categoria aléa nos faz sentir o calafrio da incerteza, mas também temos a segurança de que aquela situação não passa de uma brincadeira. Porém, vivemo-la de modo intenso. A cada dado jogado no tabuleiro, nossa vida está ali, representada naquele minúsculo objeto que anda de casa em casa e que, às vezes, salta uma, ou volta duas casas. $\mathrm{O}$ ir e vir nas veredas desse jogo indica que o percurso não é linear, que há vicissitudes, imprevistos, 
atropelos e também boa sorte. É uma condição de competir que muitas vezes não depende somente de nossa sapiência, pois o acaso encontra brechas para se fazer presente.

É fato que buscamos brincadeiras que nos tiram do eixo das sensações normais. O desequilíbrio torna-se um deleite e o mundo é virado de ponta-cabeça. A vertigem, mesmo nos causando um pouco de náusea, nos permite alterar a consciência, e a nossa percepção fica mais aguçada. Pulamos corda, giramos, fechamos os olhos, ficamos de cabeça para baixo, enfim, queremos ver o mundo por outro ângulo. A força do ilinx nos leva a esse estado diferenciado de olhar e escutar o mundo. Tudo se deforma aos nossos olhos. O mundo gira, as coisas saem do lugar e nos movemos desequilibradamente. Afinal, para andarmos, uma das condições é a relação entre o equilíbrio e o desequilíbrio. Se não fosse assim, não sairíamos do lugar.

Igualmente, nos aprazem aqueles jogos que nos fazem pensar e rachar a cuca. Montar o quebra-cabeça, retirar dois aros de metal, adivinhar uma daquelas “o que é o que é?", descobrir a palavra, entre outras, são situações que nos levam a exercer nossa potencialidade de refletir, de imaginar e de usar nossa cognição como meio quase que específico para que a brincadeira aconteça. Usamos nosso intelecto para decifrar códigos e enigmas. Vamos ao encontro dos jogos porque há algo de misterioso que nos atrai. Gostamos de adivinhar as charadas, encontrar as palavras. Nesses jogos está presente a categoria aenigma.

No universo dos jogos, podemos identificar cinco categorias nas quais as brincadeiras se constituem. Essas categorias são o alicerce e o tempero dos vários jeitos de brincar. Elas colorem e dão vida às brincadeiras que se apresentam. E, como os jogos não têm um resultado prévio, a incerteza, aliada às regras e à sua natureza constitutiva, possibilita ao jogador renovar sua presença no jogo a cada instante jogado.

Se olharmos mais de perto, não há nenhuma dessas categorias que se apresente em uma brincadeira de forma unívoca. Em cada jogo há um quê de cada uma delas. Aquele jogo que apresenta preponderância de uma categoria poder ser inserido em umas das cinco categorias descritas. O grau de presença das variáveis possíveis garante as diferenças no desenrolar da atividade.

Vamos ao encontro da brincadeira também porque queremos ter experiências. O jogo é um acontecimento. E é sobre isso que vamos falar na sequência. 


\section{A brincadeira como acontecimento}

Ao pensar sobre o instante no qual acontece a brincadeira, sabemos que ela não tem uma duração ad infinitum. Há um momento de início e um de término. Como já mencionei, ela tem uma delimitação temporal. Geralmente essa duração está diretamente relacionada com os acordos estabelecidos pelos jogadores. Por isso, a brincadeira é efêmera. Ela acontece uma vez e não se reproduz. $\mathrm{O}$ que repetem sãos seus ritos e suas estruturas. No instante de sua existência, microeventos acontecem e estes atravessam aqueles que brincam, deixando alguma marca e impelindo os jogadores a buscarem novas experiências. Nesse sentindo, a brincadeira é uma espécie daquilo que John Dewey (1976) chamou de continuum experiencial. Para esse autor, uma experiência leva à outra, possibilitando uma sucessão de experiências. O que foi experimentado anteriormente, de alguma forma permanece na memória daquele que foi sujeito da experiência. Esta faz mais sentido quando a brincadeira se caracterizou como algo significativo. O que foi vivido impacta no sujeito, deixando vestígios e criando uma expectativa para as próximas experiências. Uma solução encontrada, uma sensação percebida e uma possibilidade de descobertas criam um universo de perspectivas que darão impulso para as novas investidas nas atividades do jogo.

Aquilo que nos acontece, e estamos cientes desse acontecimento, nos indica que estamos vivos e que alimentamos nossa ludicidade, ou seja, deixamos brotar nossa capacidade de ressignificar a realidade, dando-lhe um toque de poesia e ficção. Isso gera em nós a experiência. No que tange ao jogo em nossa vida, essa experiência toca no âmbito da estética, e esse sentido toca nossa alma de brincante.

Como bem aponta Dewey (1980), a experiência é constituída por elementos repletos de improbabilidades. Complementando, esses elementos movem-se de acordo com as circunstâncias, conforme os desejos do jogador, as condições de realização e os eventos extemporâneos. Tudo isso se dirigindo para uma finalização recheada de imprevistos.

Ainda pensando com Dewey (2010, p. 82-83),

a experiência, na medida em que é experiência, consiste na acentuação da vitalidade. Em vez de significar um encerrar-se em sentimentos e sensações privados, significa uma troca ativa e alerta com o mundo; em seu auge, significa uma interpenetração completa entre o eu e o mundo dos objetos e acontecimentos. 
Essa relação entre o objeto - a brincadeira -, o mundo e o outro abarca inúmeros afetos, sentimentos, percepções, desejos, rejeições, preconceitos e demais significações da vida humana. Apesar de o jogo ser uma realidade ficcional, nele o ser humano não se aparta de sua essência. $\mathrm{O}$ sujeito está ali como um ser inteiro, com seus deleites e dores. $\mathrm{O}$ que ele busca é um tipo de estar no mundo que lhe mostre aquilo que a realidade cotidiana não dá conta. Isso o faz buscar por novas e intensas experiências.

Em contrapartida, o que foi vivenciado não dá a garantia de que a próxima experiência será exitosa, pois as situações são distintas. Dessa forma, uma resposta encontrada em determinada dificuldade pode ou não ser aproveitada na experiência seguinte. Aprender estratégias e delas fazer uso é uma atitude comum, porém, se a tomarmos como uma verdade imutável, fatalmente cairemos no equívoco de vestir a mesma camisa em corpos de tamanhos distintos, aludindo metaforicamente a esse exemplo. Sendo assim, o que encontramos como solução para uma situação deve ser encarado como uma opção a mais, mas que necessariamente precisa ser adaptado às novas realidades, como nos alerta Dewey (2010). É no instante da situação lúdica que devemos ver as possíveis soluções, mas estas não acontecem do nada. Elas estão calcadas em experiências anteriores que nos alimentam continuamente para enfrentarmos os novos desafios.

O brincar toca em nossos sentidos. Eles se aguçam, pois temos que olhar com mais atenção, ouvir com mais acuidade e ampliar nossos modos de estar no jogo. Caso contrário, seremos engolidos por suas entranhas. É certo que o jogo ofusca o estar presente do jogador. Porém, de modo contrário, o jogador precisa se precaver diante da brincadeira. Se ele não tomar consciência disso, o jogo o absorverá e o retirará de sua lucidez. Imagine, caro leitor, se no jogo de queimada o jogador estiver fora de si? O adversário irá, sem sombra de dúvidas, aproveitar desse ofuscamento e ganhar facilmente a partida. Estar no jogo impõe estar alerta, seja qual jogo for.

Do mesmo modo, ao abordar os sentidos na experiência artística, Dewey (2010, p. 88) afirma:

o "sentido" abarca uma vasta gama de conteúdos: o sensorial, o sensacional, o sensível, o sensato e o sentimento, junto com o sensual. Inclui quase tudo, desde o choque físico e emocional cru até o sentido em si - ou seja, o significado das coisas presentes na 
experiência imediata. [...] Os sentidos são os órgãos pelos quais a criatura viva participa diretamente das ocorrências do mundo a seu redor. Nessa participação, o assombro e o esplendor deste mundo se tornam reais para ela nas qualidades que ela vivencia. Esse material não pode ser contrastado com a ação, porque o aparelho motor e a própria "vontade" são os meios pelos quais essa participação é levada a cabo e dirigida. Não pode ser contrastado com o "intelecto", porque a mente é o meio pelo qual a participação se torna fecunda através do juízo [senso], pelo qual os significados e valores são extraídos, preservados e colocados a serviço de outras questões, na relação criatura viva com o meio que a cerca.

O brincar gera uma relação diferenciada entre os sujeitos que brincam e o meio no qual compartilham a brincadeira. $\mathrm{O}$ que os faz perceber esse meio é o aguçamento dos sentidos dirigidos ao encontro com o outro. Na brincadeira, as potencialidades de ressignificação das diversas materialidades imperam no momento em que acontece o jogo. $\mathrm{O}$ olhar atento procura por novas estratégias, novos modos de agir e estabelecer conexões baseadas nas regras acordadas e nas atitudes dos outros jogadores.

Pensando assim, a brincadeira é um acontecimento no qual os sujeitos são protagonistas de cada ação no interior da situação lúdica. Uma atrás da outra, as decisões no brincar vão em direção à consumação de uma experiência única que leva os jogadores a se disporem a novos desafios. No acontecimento da brincadeira, o brincante tem uma experiência.

\section{Brincar é estar com 0 outro}

A palavra brincar, em seu sentido etimológico, quer dizer vínculo. $\mathrm{Na}$ esfera do jogo, os laços são feitos, ainda que temporariamente. $\mathrm{O}$ contato e o convívio proposto pelos jogos vão à contramão dos tablets, smartphones, notebooks e nas ditas redes "(anti)sociais". Esses aparatos são meios importantes e ferramentas que podem auxiliar em nosso dia a dia, mas o que venho observando é que as pessoas se conectam na rede para se desconectarem de onde estão. A rede as engolfa. A convivência com o outro está se tornando uma coisa rara. Fugimos do olhar, do cheiro, da voz e do toque daquele que está diante de nós. A brincadeira, ao contrário, busca um modo de convivência que desafia as pessoas a se enfrentarem de maneira que o adversário seja seu parceiro, que o seu 
companheiro de jogo seja aquele que no instante da brincadeira lhe dá a mão e compartilha o momento.

Brincar é uma forma de estar com o outro, de se dispor a estar em relação de trocas de afetos, de desafetos, de conflitos e acertos, de alegrias e decepções. O mundo que se apresenta na brincadeira se diferencia da realidade, mas o que acontece de fato nesse espaço e tempo é uma realidade ficcional.

A experiência de brincar começa na infância. Isso não é nenhuma novidade, mas com o passar dos anos, fechamo-nos para ela e não nos permitimos entrar nessa atmosfera. Criamos preconceitos e enjaulamos nossas potencialidades lúdicas. Daí, afirmamos categoricamente: brincar é coisa de criança. Ao adulto não é permitido entrar no universo da fantasia, a não ser em determinados tipos de jogos ditos de adultos. É claro que não iremos mais brincar de casinha, de carrinho ou de algo que é de primazia de um período de nossa vida. Porém, ao nos dispormos a entrar nesse universo, aquilo que esteve presente em nossa infância ascende e acende em nossa memória e nos torna aptos a experimentar, de outro lugar, os efeitos de entrar no jogo e dele nos apropriar, com suas incertezas, desafios, tensões e alegrias.

Retomando ao princípio deste texto, entendo a brincadeira como algo que está latente em cada um de nós desde que nascemos. No contato com o outro, criamos um espaço de convívio no qual as relações ficcionais acontecem de fato e os jogadores são instigados a se desafiarem no contorno de um temenos. Os impulsos formal e sensível se incorporam no impulso lúdico, configurando-se em uma situação na qual os limites de espaço e tempo, tendo as regras como balizas, se coadunam para que o acontecimento não se esvaia. Seja pelo desejo de imitar, ter vertigem, jogar a sorte, disputar ou desafiar-se intelectualmente, o jogador vai ao encontro do jogo pela sua vontade de ali estar. Ele sabe que, para o jogo acontecer, a brincadeira precisa de seu consentimento. $\mathrm{O}$ desejo de entrar no jogo denota que o jogador está disposto a se expor e estar presente diante dos acontecimentos. A estrutura e a vontade de estar naquela situação lúdica transformam os sujeitos em jogadores. O que nos impele ao jogo é o desejo de desafio, de imaginar, de viver a tensão das incertezas sem correr riscos reais, de entrar no mundo ficcional e de alterar a nossa percepção. No temenos, esse espaço demarcado e delimitado no tempo orienta as atitudes e dá margem para a invenção. Nele, tudo pode acontecer, mas não pode acontecer qualquer coisa. Nesse acontecimento, 
aqueles que brincam interagem, se manifestam, se expressam e se relacionam entre conflitos, entendimentos, equívocos e acertos. Os brincantes escolhem as ações e declaram: "Estamos no jogo". Ou seja, estamos juntos!

\section{Referências}

Bettelheim, B. Uma vida para seu filho: pais bons o bastante. Trad. de Maura Sardinha e Maria Helena Geordane. Rio de Janeiro: Campus, 1988.

Brougère, G. Jogo e educação. Porto Alegre: Artes Médicas, 1998.

CaIllois, R. Os jogos e os homens: a máscara e a vertigem. Trad. de Maria Ferreira; rev. téc. de Tânia Ramos Fortuna. Petrópolis: Vozes, 2017. (Coleção Clássicos do Jogo).

Dewey, J. Experiência e educação. São Paulo: Companhia Editora Nacional, 1976.

Dewey, J. Experiência e natureza. Lógica: a teoria da investigação. A arte como experiência. Vida e educação. Teoria da vida moral. São Paulo: Abril Cultural, 1980.

Dewey, J. Arte como experiência. Trad. de Vera Ribeiro. São Paulo: Martins Fontes, 2010.

Eco, U. Sobre os espelhos e outros ensaios. Rio de Janeiro: Nova Fronteira, 1989.

Huizinga, J. Homo ludens. São Paulo: Perspectiva, 1993.

Kishimoto, T. M. O jogo e a educação infantil. São Paulo: Pioneira, 1998.

Pereira, E. T. Práticas lúdicas na formação vocal em teatro. São Paulo: Hucitec, 2015.

SCHiller, F. Cartas sobre a educação estética do homem. São Paulo: EPU, 1992. 


\section{CAPÍTULO 4}

\section{LETRAMENTO DIGITAL: ENTRE A APROPRIAÇÃO E A PROIBIÇÃO DAS PRÁTICAS DIGITAIS DE LAZER NA FORMAÇÃO DE ADOLESCENTES}

Guilherme Carvalho Franco da Silveira

Rafael Fortes

Jogos eletrônicos, sites de redes sociais, fanfics ${ }^{1}$, mensagens instantâneas, fotos, vídeos, filmes, música, informação, entretenimento, namoro, nudes, compras. Como afirma Buckingham (2010, p. 39), "a mídia digital - internet, telefonia móvel, jogos de computador, televisão interativa - hoje é um aspecto indispensável no tempo de lazer das crianças e dos jovens". Entretanto, apesar de haver uma tendência de considerar que as crianças, os adolescentes e os jovens conseguem dominar sozinhos, com muita facilidade, as mídias digitais, se analisarmos habilidades mais complexas, encontramos sujeitos com dificuldades importantes, as quais muitas vezes resultam de um contexto desfavorável em escolaridade, renda, relações sociais e familiares (CARvalHO, 2010). Em contraposição, há um discurso, sem fundamentação empírica significativa, sobre os perigos das práticas digitais ${ }^{2}$ para crianças e adolescentes, além de certo desprezo

1 Fanfic vem da junção, em inglês, das palavras fan (fã) e fiction (ficção), significando histórias criadas por fãs de determinado filme, seriado, romance, entre outros, e inspiradas nos personagens ou na história original.

2 Práticas digitais entendidas não apenas como aquelas que as pessoas realizam em celulares, tablets, consoles e computadores, mas também as práticas relacionadas a elas $e$ ao redor delas: conversas sobre um aplicativo ou site, troca de informações sobre um jogo eletrônico, apreciação de práticas de amigos e colegas (por exemplo, assistir, presencialmente, a um colega postar algo em uma rede social ou torcer para um amigo enquanto ele joga um jogo eletrônico) etc. 
quanto a tais práticas como atividade de lazer, remetendo a uma infância ou adolescência de um passado idealizado no qual supostamente dedicavam a brincadeiras todo ou quase todo o tempo livre 3 .

Nesse contexto, qual o papel das instituições educativas (em especial, escolas e projetos sociais) diante da atual relação entre adolescentes e mídias digitais? Repensar a (não) formação intencional desses sujeitos para viver na cultura digital parece uma tarefa urgente. Entretanto, a mera disponibilidade de computadores e de acesso à internet, como é o caso em algumas instituições, apesar de necessária, não é suficiente, sendo crucial questionar a ideia de se atribuir "uma perspectiva revolucionária ao simples acesso à tecnologia" (CARvalho, 2010, p. 31). Da mesma forma, a omissão desse debate por considerar os adolescentes "nativos digitais", que supostamente transitam natural e competentemente na cultura digital, uma vez que já nasceram imersos nela (PRENSKY, 2001), ou o enfrentamento das práticas digitais apenas no âmbito das proibições e restrições, baseadas nos possíveis efeitos negativos das mídias nesses sujeitos, também não parecem contribuir para uma apropriação lúdica, crítica e competente das práticas digitais.

Partindo da ideia de que as mídias digitais se constituem em mais uma possibilidade de desfrutar a vida cotidiana, de aprender, de construir identidades e de compreender e se relacionar com o mundo, o presente capítulo, inspirado nos dados da pesquisa de doutorado Entre celulares, tablets, consoles e computadores: práticas digitais de adolescentes numa escola pública de ensino fundamental ${ }^{4}$, busca refletir sobre as possibilidades de formação de adolescentes em diálogo com essas práticas, que preponderantemente têm se revelado como atividades de lazer. Para tanto, vamos inicialmente refletir sobre o significado de letramento digital e sobre as práticas digitais dos adolescentes para, então, pensar

3 Por exemplo, segundo Santos (1977), em 1975, em bairros de diferentes condições socioeconômicas, na cidade de São Paulo, o número de horas por dia que crianças e adolescentes de 9 a 14 anos despendiam vendo TV (4,1 horas) era maior que o tempo que gastavam brincando (menos de 1,5 hora).

4 Pesquisa realizada por Guilherme Carvalho Franco da Silveira e orientada por Rafael Fortes no Programa de Pós-Graduação Interdisciplinar em Estudos do Lazer, da Escola de Educação Física, Fisioterapia e Terapia Ocupacional da Universidade Federal de Minas Gerais (UFMG). A pesquisa é desenvolvida no Centro Pedagógico da Escola de Educação Básica e Profissional da UFMG, na qual o doutorando também atua como professor. 
possibilidades de letramento digital que possam ser incorporadas por escolas e projetos sociais.

\section{Letramento digital}

Eu não me acho entendido de tecnologia. Tem muita coisa que eu queria saber e não sei: editar vídeo, hackear para pegar wi-fi e outras coisas. Egídio, 12 anos $^{5}$

Há diferentes expressões para se referir à formação para lidar com a cultura digital: inclusão digital, letramento digital, letramento midiático, letramento na internet, letramento em novas mídias, letramento transmídia (SCOLARI, 2018). Uma vez que o conceito de inclusão, em sua versão tradicional, leva em consideração apenas o acesso puro e simples às mídias digitais (BuzATo, 2007), optamos por trabalhar, no presente texto, com o conceito de letramento digital, entendido como as "redes complexas de letramentos (práticas sociais) que se apoiam, se entrelaçam, se contestam e se modificam mútua e continuamente por meio, em virtude e/ou por influência das TIC"6 (BuzATo, 2007, p. 168).

Nessa direção, nos apropriamos da argumentação de Buckingham e Burn (2007) sobre o letramento digital em jogos eletrônicos para pensar o letramento digital de forma mais ampla em suas dimensões lúdica (aspectos relacionados à imersão, ao prazer, à sensibilidade, à sociabilidade), funcional (habilidade de operar as mídias digitais e seus respectivos softwares), crítica (análise, avaliação e crítica dos produtos e dos contextos sociais, econômicos, políticos e institucionais de produção e

5 Todos os nomes neste texto são fictícios, para resguardar a identidade dos adolescentes. Os participantes da pesquisa tinham entre 12 e 14 anos quando os dados foram coletados.

6 Tecnologias da Informação e Comunicação. Essa nomenclatura nos parece limitada, pois, para além de informação e comunicação, o prazer e o lúdico relacionados às práticas digitais (jogos eletrônicos, música, filmes, leitura, vídeos, sites de redes sociais etc.) são aspectos mais ligados à apreciação e ao entretenimento e, no mínimo, tão importantes quanto informação e comunicação. Por esse motivo, preferimos a expressão mídias digitais. 
distribuição das mídias e a compreensão de como isso afeta a vida das pessoas) e criativa (a produção cultural com as mídias).

Tendo essa concepção de letramento digital em mente, em meio a adolescentes que são potenciais "prosumidores" (produtores + consumidores), inexoravelmente envolvidos em maior ou menor grau em atividades de consumo, interpretação, criação e compartilhamento de mídias de diferentes tipos e níveis de complexidade (SCOLARI, 2018), e cujo envolvimento com as mídias digitais extrapola a (in)capacidade de lidar tecnicamente com dispositivos, softwares e aplicativos, parece-nos interessante construir uma proposta de ação inspirada em três autores:

1. Lave (1991), com sua concepção de aprendizagem situada, que é, como explica Faria (2008, p. 26), um "processo pelo qual aprendizes participam em comunidades de prática em que o domínio do conhecimento e das habilidades requer movimento em direção à participação plena nas práticas socioculturais" (em nosso caso, as práticas digitais), em uma dinâmica em que a aprendizagem é inseparável da participação social cotidiana;

2. Buckingham (2016), que sugere levar em consideração no planejamento de ações de letramento digital quatro conceitos-chave, quais sejam: representação: a ideia de que as mídias representam o mundo (em vez de o refletirem), incorporando certos valores, ideologias e interesses que precisam ser compreendidos; linguagem: como a linguagem digital é construída (sites, imagens, vídeos, textos, links etc.); produção: compreensão de quem está comunicando o que e com qual interesse (aspectos comerciais, ideológicos, políticos etc.); audiência: consciência do sujeito de sua posição como leitor ou usuário, compreendendo como as mídias são direcionadas a certas audiências e como diferentes audiências respondem a elas;

3. Melo (2006), com sua proposta de animação cultural, baseada nas seguintes possibilidades de diálogo entre arte e esporte: a utilização da arte para discutir a prática esportiva em si; a utilização da arte para uma discussão ampliada por meio do

7 Prosumers, no original. 
esporte e a utilização da arte por meio do esporte para uma educação para a arte. Pensando o letramento digital em uma perspectiva de animação cultural (e distanciando-nos do modelo bancário de educação formal), entendemos ser possível traduzir essa proposta de Melo do campo da arte e do esporte para o campo da cultura digital. Nessa tradução, partiríamos das práticas digitais dos próprios adolescentes para então refletir com eles sobre suas ações e sobre a adolescência em si no contexto da cultura digital.

É importante, ainda, fazer a distinção entre uma proposta de letramento digital como formação para se apropriar e viver em meio à cultura digital (que é o que discutimos neste texto) e outra ideia, não menos importante (e relacionada à primeira), mas diferente em suas intenções, que é a utilização das mídias digitais como recurso didático para o ensino de conteúdos do currículo da educação básica (educação física, arte, matemática, português, história, geografia, ciências, inglês), mas que não será discutida aqui.

\section{Adolescentes: nativos digitais ou brincantes digitais?}

Em pesquisa de campo, foi possível observar adolescentes em diferentes práticas digitais. Assim, podemos afirmar que cada um deles se mostrou especialista naqueles aplicativos que lhe interessavam: uma rede social em particular (Instagram, Facebook, Twitter, Snapchat, Musical. ly, WhatsApp etc.), um jogo específico (GTA, FifA, Slither.io etc.), entre outras possibilidades, mas não um nativo digital que transita competentemente por quaisquer mídias nem por todas as dimensões de letramento (lúdica, funcional, crítica, criativa) apontadas por Buckingham e Burn (2007). Se é que vale a pena criar outro rótulo para a complexa relação com as práticas digitais em que se envolvem, poderíamos afirmar que os adolescentes são brincantes digitais, uma vez que se destaca de forma admirável a dimensão lúdica da maioria de suas atividades (geralmente, associada ao desejo de sociabilidade).

Os adolescentes observados tinham muito mais habilidade de navegação no interior das mídias digitais que de interpretação crítica do que consumiam ou de produção de conteúdo novo, sendo extremamente ágeis para atividades simples, como se cadastrar em aplicativos, acessar 
as diferentes possibilidades de ação em cada um, mudar configurações, ver e compartilhar posts, localizar amigos, dar likes, entre outras. Da mesma forma, muitas vezes apresentavam dificuldade de imaginar as consequências de suas práticas digitais e de calcular o público (para além dos amigos cadastrados) que acessaria seus posts, imagens e vídeos.

Mesmo as habilidades mais simples, meramente funcionais, não eram amplamente dominadas. Quando a atividade fugia um pouco do seu domínio de interesse, muitos adolescentes da escola apresentavam sérias dificuldades. Por exemplo, ao realizarem um trabalho em computadores do laboratório de informática, vários tiveram dificuldade de trabalhar no LibreOffice Impress (os que tinham computadores em casa, utilizavam o PowerPoint e tiveram problemas em encontrar os comandos apropriados no aplicativo que desconheciam). Quando decidimos salvar todos os trabalhos no OneDrive, solicitando que os alunos transpusessem a apresentação do Impress para o PowerPoint, vários chegaram a ponto de desistir, tal a dificuldades de transpor o conteúdo de um aplicativo para outro. Da mesma forma, quando precisaram continuar a edição do documento abrindo-o no OneDrive e editando o PowerPoint on-line, mais uma rodada de lamentações teve lugar. Outro problema foi o de transpor imagens encontradas na internet para o aplicativo, uma vez que as estratégias de copiar e colar utilizadas em casa não funcionavam nos computadores da escola.

Foi muito comum também percebermos certa ingenuidade dos adolescentes ao não avaliarem criticamente as consequências de suas práticas digitais (principalmente o fato de que elas deixam rastros) e não entenderem o viés de determinados aplicativos, opiniões, notícias, como no caso de fake news, que aos olhos de alguns deles pareciam verdades absolutas, ou da reprodução acrítica de posts e vídeos preconceituosos, falsos ou discriminatórios. Os vários casos de mensagens privadas entre amigos no WhatsApp que foram compartilhadas com outras pessoas não diretamente pelos aplicativos, mas pela exibição da própria tela do celular e gerando conflitos inesperados, são mais um pequeno exemplo da dificuldade dos adolescentes em lidar com a complexidade social (e não apenas técnica) de suas práticas digitais.

Rosado e Tomé (2015, p. 22) afirmam que a geração de adolescentes e jovens contemporâneos "se mostrou nativa dos ambientes digitais pelo alto grau de participação nas redes sociais, principalmente na comunicação com os pares da mesma idade que pertencem ao convívio 
comunitário e da escola”. Entretanto, o que se deve questionar é qual o sentido que se atribui à natividade: simplesmente habitar as mídias digitais (sites de redes sociais, jogos eletrônicos, YouTube etc.) ou ser competente no uso, na apropriação crítica e na produção das mídias? Os mesmos autores apontam que, apesar da grande participação nas redes sociais on-line, jovens tendem a reproduzir e compartilhar conteúdo de terceiros mais do que produzir os seus próprios. Segundo eles, referindo-se a alunos brasileiros e portugueses, "a quantidade do que é produzido e compartilhado pelos alunos (produto autoral) se mostrou baixa, apesar da disponibilidade dos recursos próprios para gravação e edição multimídia em celulares e tablets" (RosAdo; ToMÉ, 2015, p. 19), o que denota uma participação banal e nada especial (no que diz respeito a letramento digital), corroborando o que Buckingham (2010) e esta própria pesquisa indicam.

Concordamos com Boyd (2014, p. 22), quando afirma:

o termo nativo digital é um para-raios para os intermináveis medos e esperanças que muitos adultos anexam à nova geração. As narrativas da mídia geralmente sugerem que as crianças hoje - aqueles que cresceram com a tecnologia digital - estão equipados com maravilhosos novos superpoderes. Suas habilidades multitarefa supostamente impressionam adultos quase tanto quanto suas três mil mensagens de texto por mês. Enquanto isso, os mesmos incansáveis relatos na mídia também avisam o público que essas crianças são vulneráveis a novos perigos sem precedência: predadores sexuais, cyberbullying e miríades de formas de declínio moral e intelectual, incluindo vício em internet, atenção diminuída, menor letramento, compartilhamento despreocupado, e por aí vai. [...] A chave para entender como os jovens navegam nas mídias sociais é se afastar das manchetes - tanto boas quanto ruins - e mergulhar nas realidades cheias de nuances das pessoas jovens ${ }^{8}$.

A competência digital está, certamente, ligada também a questões de desigualdade social. No universo pesquisado, havia adolescentes cujo plano de celular não era $3 \mathrm{G}$ ou $4 \mathrm{G}$. Com isso, só acessavam a internet no aparelho por meio de wi-fi, uma forma de conexão que muitas vezes não está disponível, como é o caso da escola. Isso significa uma limitação no

8 As traduções neste texto são de Guilherme Carvalho Franco da Silveira. 
uso do celular, dificultando baixar aplicativos, jogar on-line, conversar por WhatsApp, postar no Facebook etc. Outros adolescentes relataram, por exemplo, que a velocidade da internet em casa dificultava assistir a conteúdos na Netflix ("não consigo ver filmes e seriados sem que a transmissão pare”) e jogar on-line com outros jogadores. Uma adolescente às vezes ia ao laboratório de informática ao final das aulas para baixar músicas e ficava sempre surpresa com a velocidade com que conseguia fazer o download. No entanto, havia adolescentes que não só tinham internet rápida nos celulares e em casa como aproveitavam essa oportunidade para adquirir conhecimentos relativos às práticas digitais e aos conteúdos curriculares. Por exemplo, Célia relatou que aprendeu inglês quase exclusivamente assistindo a séries e filmes na Netflix. Ela chegou a frequentar um curso de inglês, mas desistiu dele e começou a assistir a séries com o áudio em inglês. Segundo a aluna, inicialmente ela deixava as legendas em português e áudio em inglês. Depois passou a deixar também as legendas em inglês e, por fim, suprimiu as legendas quando começou a entender o áudio em inglês sem necessidade de apoio das legendas. Casos como esse, entretanto, foram muito mais exceções do que a regra.

Ou seja, a não ser que em casa os adolescentes realizassem em celulares, tablets e computadores práticas espetaculares e totalmente diferentes daquelas observadas na escola, o que nos parece bastante improvável, segundo até mesmo o relato dos próprios alunos, o que se percebeu foi que a maioria deles navegava em um conjunto nada especial de práticas digitais. Estas não são muito diferentes, qualitativamente, daquelas em que os adultos se envolvem, mais focadas em seu próprio lazer, na comunicação com os pares e na autoexpressão do que em aprendizagens "sérias" ou em ações arriscadas para sua formação, tais como encontros com estranhos, cyberbullying, publicação de informações privadas, entre outras. Como afirmam Carnicelli, McGillivray e McPherson (2017, p. 223), é preciso

olhar para além de dicotomias simplistas de imigrantes digitais e nativos digitais para explorar o desequilíbrio de acesso, participação e resultados de tecnologias e plataformas digitais. Nem todos participam, e aqueles que participam o fazem de diferentes maneiras, em contínuas lutas por reconhecimento, poder e status, um aspecto de plataformas digitais, desde Facebook a FifA 16.

Entretanto, é notório que os adolescentes transitam incessantemente pelas mídias digitais, fazendo delas parte indissociável de seu cotidiano. 
No centro das práticas digitais desses sujeitos estão o lazer, o lúdico e a sociabilidade, três elementos intimamente relacionados, uma vez que entendemos a sociabilidade na perspectiva de Simmel (1983, p. 169), que a define como a forma lúdica da sociação9 e cujo alvo "não é nada além do sucesso do momento sociável e, quando muito, da lembrança dele”. A sociabilidade, nesse sentido, foi observada em diversas situações em que, mais que o jogo em si, o vídeo ou a rede social acessada, o que parecia importar era a interação "acompanhada por um sentimento, uma satisfação, pelo fato de se estar associado com outros e de que a solidão do indivíduo é convertida em união, a união com os outros" (SIMMEL, 1949, p. 255). Como manifestações de lazer que aproximam os adolescentes presencial e virtualmente, práticas digitais on-line e off-line estão absolutamente conectadas e inter-relacionadas, especialmente quando adolescentes estão próximos fisicamente uns dos outros e ao mesmo tempo acessando as mídias digitais. Nessas situações, pode-se falar de uma sociabilidade ao redor das práticas digitais, uma das características mais marcantes observadas. Foi raríssimo ver algum adolescente sozinho nos pátios, quadras, corredores e salas da escola. Em praticamente todos os espaços da escola pesquisada, os celulares faziam parte das cenas observadas, mas não eram os aparelhos em si a atração das práticas digitais dos adolescentes; eles eram, no máximo, mediadores das conversas. Fosse na sala de aula ouvindo música no celular, deitados nos corredores contando casos de crushes e de sites de redes sociais ou simplesmente próximos uns dos outros, jogando em celulares, o ponto de partida era o interesse comum entre eles, e o resultado era uma interação intensa mediada pelo prazer de estar juntos.

Esse fato corrobora a ideia de Veissière e Stendel (2018) de que o pânico moral sobre um suposto vício em smartphones (e em outras mídias, poderíamos acrescentar) desconsidera uma questão fundamental: mais do que uma propriedade viciante das próprias mídias, são as expectativas de sociabilidade e de recompensas pela interação e aprendizagem com outras pessoas que induzem e sustentam relações intensas com os

9 Para Simmel (1983, p. 166), “a sociação é a forma (realizada de incontáveis maneiras diferentes) pela qual os indivíduos se agrupam em unidades que satisfazem seus interesses. Esses interesses, quer sejam sensuais ou ideais, temporários ou duradouros, conscientes ou inconscientes, causais ou teleológicos, formam a base das sociedades humanas". 
smartphones, simplesmente porque são eles que permitem a intensificação e/ou a continuidade da sociabilidade quando ela não é possível presencialmente (seja porque não há amigos perto de casa ou porque, como muitos adolescentes relataram na pesquisa, os pais não permitem que o filho saia às ruas, com medo da violência, do tráfico de drogas e/ou de acidentes de trânsito).

Talvez isso também explique o fato de que a posse de um celular rapidamente expunha seu portador à curiosidade dos colegas ("O que você está fazendo?”, “O que está jogando?”, “Com quem está conversando?”). Parecia impossível, entre os adolescentes da pesquisa, isolar-se com um celular nas mãos quando se estava em meio aos seus pares. Essa realidade nos remete a um jogo de futebol americano observado por Boyd (2014, p. 3), quando o foco eram os adolescentes e seus aparelhos de celulares. Segunda a autora:

Os adolescentes não estavam fazendo ligações. Eles usavam seus celulares para tirar fotos e muitos enviavam mensagens freneticamente enquanto tentavam achar uns aos outros na multidão. Assim que eles se conectavam [visualmente], as mensagens geralmente paravam. Embora alguns adolescentes enviem mensagens de texto com frequência, os adolescentes ali não estavam direcionando a maior parte de sua atenção para seus aparelhos. Quando olhavam para seus telefones, eles estavam frequentemente compartilhando sua tela com a pessoa ao seu lado, lendo ou vendo algo juntos.

Assim como na situação observada por Boyd (2014), na escola pesquisada o que interessava aos adolescentes eram a comunicação, as relações e as interações entre eles, e não o celular em si. Esse foi um traço comum a quase todas as práticas digitais durante todo o tempo da pesquisa de campo. Mesmo nos momentos em que estava cada um fazendo uso do próprio celular, nos corredores da escola, os adolescentes também interagiam face a face, curtindo, comentando e compartilhando, não no smartphone propriamente, mas sim fisicamente, ao redor do uso do celular: eles curtiam o que viam na tela dos colegas; comentavam um post ou foto no site de rede social dos amigos; compartilhavam o próprio celular (para que o colega, que não tinha celular ou tinha um aparelho inferior em processamento de dados ou velocidade de conexão, acessasse redes sociais ou jogasse), compartilhavam os fones de ouvido, curtindo uma mesma música; enfim, se divertiam em interações frente a frente ao redor de práticas digitais. 
Em outras situações, on-line e off-line, os adolescentes ficavam mais claramente separados (mas não desconectados, uma vez que o on-line geralmente se refere a relações prévias off-line), como quando se está em casa, distante dos amigos, situação em que o virtual assume uma importância muito grande exatamente por suprir a ausência das relações sociais presenciais. Isso foi o que expressou Ariel, quando comentou que, sozinho em casa, eram as práticas digitais que o entretinham, mas quando elas cessavam (fosse porque um jogo acabava ou um amigo se despedia em uma rede social) ele se via diante de um mundo particular entristecido, pois não havia amigos com quem compartilhar conversas, brincadeiras, curiosidades.

Importa ainda destacar que os adolescentes, segundo eles próprios, não estavam deixando de realizar outras práticas de lazer por causa das práticas digitais ${ }^{10}$. Ao contrário, as práticas digitais ou eram atividades que intensificavam e enriqueciam os encontros presenciais (jogar juntos, conversar sobre as últimas notícias e fofocas, compartilhar segredos, registrar momentos importantes de sua vida etc.) ou eram o que lhes restava, uma vez impossibilitados de encontrar seus pares e/ou de fazer atividades que apreciavam (cinema, festas, esporte, dança, passeios etc.).

A ideia de Boyd (2014) de que, em sua maioria, os adolescentes não são menos sociáveis (nem se divertem menos!) quando se engajam intensamente com as mídias digitais foi confirmada pela riqueza de possibilidades lúdicas compartilhadas nas práticas digitais na escola pesquisada. Mais que nativos digitais, percebemos os adolescentes como brincantes digitais, sujeitos que incorporaram também as mídias digitais na perspectiva de experiências lúdicas.

A frequência e a intensidade com que as mídias digitais são apropriadas nas práticas de lazer dos adolescentes, assim como a observação, em certos momentos, do seu uso incompetente ou acrítico, da dificuldade de interpretação de informações veiculadas na internet e de situações problemáticas ao redor das práticas digitais revelam tanto a urgência de ações na direção do letramento digital (Livingstone, 2011) quanto a necessidade de compreender melhor a relação entre lazer e cultura digital na construção das identidades e do cotidiano dos adolescentes de hoje.

10 Apesar de alguns adolescentes terem afirmado perceber uma diminuição do tempo de leitura e estudo em virtude do envolvimento com as mídias digitais, algo que consideramos merecer outro estudo. 


\section{Letramento digital: da proibição à apropriação das práticas digitais de lazer na formação de adolescentes}

Medo, preocupação, proibição, controle e vigilância são categorias marcantes na relação entre os adultos e as práticas digitais dos adolescentes. Escola, projetos sociais, administradores, pais, professores e educadores (não todos, obviamente, mas muitos desses sujeitos e instituições) têm insistido na negação ou na suposta proteção dos direitos dos adolescentes. Seja a negação do acesso ao wi-fi da escola, a tentativa de proibição de certas práticas digitais até mesmo no tempo de recreio e almoço, a restrição de tempo em casa (muitas vezes não acompanhada da reflexão sobre a qualidade do uso), quando não a chantagem (Obedecer tal ordem ou ficar sem os dispositivos digitais; fazer as coisas corretamente ou ficar proibido de usar as mídias digitais) ou o tratamento das mídias como um prêmio (ou punição) ao bom (mau) comportamento (Apresentar boas notas, cumprir as obrigações, para ficar autorizado a ter acesso às mídias; ao cometer um erro, ficar afastado de práticas digitais por tanto tempo), a pesquisa desvelou uma série de ações de adultos cujo sentido é interditar as práticas digitais dos adolescentes sem um correspondente diálogo sobre os motivos e o sentido de tais restrições.

Tensionando essas restrições, foram marcantes e frequentes na pesquisa a observação e os relatos de diferentes formas de burlar proibições ou obstáculos às práticas digitais. Essas burlas acabavam empurrando uma série de práticas digitais para situações de dissimulação e encobrimento, ou seja, os adolescentes apenas escondiam tais práticas dos adultos, mas não deixavam de realizá-las. Assim, quando não se permite a abertura de uma prática digital, o fato é que muitas daquelas que os adultos imaginam proibir ou restringir continuam a ser realizadas pelos adolescentes, seja na casa de um amigo, no celular de um colega ou irmão, pelo wi-fi hackeado ou mesmo em casa ou na escola, escondidos dos adultos. Se concretamente as práticas proibidas continuam a ser realizadas, não seria melhor reconhecer tal evidência e pensar em possibilidades de formar os adolescentes para lidar com mais autonomia com o que os adultos consideram impróprio ${ }^{11}$ ?

11 Tal postura dos pais e/ou responsáveis pode estar ligada à arraigada cultura restritiva e proibicionista, isto é, o insistente "exercício de poder para enfrentar o que não se entende" (Dores, 2003, p. 11). Na sociedade brasileira, práticas amplamente dissemi- 
Entendemos que os processos de letramento digital devem conjugar esforços com aquilo que Valkenburg et al. (2013) chamam de estratégias de mediação para a autonomia (em que se reflete, com os adolescentes, sobre a qualidade, as possibilidades e riscos e as consequências das práticas digitais), em contraste com estratégias de restrição ou proibição de cunho autoritário que desconsideram o diálogo com adolescentes quanto ao uso das mídias digitais.

Uma vez que as práticas digitais dos adolescentes são tão fortemente relacionadas ao lazer e à sociabilidade, ações de formação que partem da relação lúdica com as mídias digitais nos parecem apropriadas. Independentemente da escola e dos projetos sociais, os adolescentes aprendem com as práticas digitais, mas entendemos que essas instituições não se podem furtar à responsabilidade de também participar da aprendizagem com e sobre as mídias digitais. Como pensar então, concretamente, essas ações de formação?

Em primeiro lugar, propomos iniciar-se com momentos em que os adolescentes, com professores/educadores, possam se envolver em suas práticas digitais cotidianas para que se compreendam quais e como elas são e as relações on-line e off-line nelas estabelecidas. A apreciação e o desfrute de práticas digitais em escolas e projetos sociais podem soar estranhos a professores e educadores, pois, como afirma Scolari (2018), os protocolos educativos das escolas (e de muitas famílias e de certos projetos sociais) costumam distanciar-se da vida dos adolescentes, que por sua vez circulam, atualmente, ao redor de um conjunto diversificado de mídias digitais e de novas práticas sociais. Entretanto a pesquisa demonstrou que compartilhar tais práticas com os adolescentes, estar ao redor das práticas digitais deles e conversar sobre o que se vê e o que se faz é um promissor primeiro passo. Isso porque, como a pesquisa permitiu desvelar, lazer, ludicidade e sociabilidade estão no centro das práticas digitais dos adolescentes, então partir daquilo que tem sentido para eles significa maior probabilidade de sucesso em uma aproximação. Sejam práticas

nadas seguem proibidas, tais como abortar, fumar maconha, apostar no jogo do bicho, em competições esportivas e casar (no caso de casais de Lésbicas, Gays, Bissexuais, Travestis, Transexuais ou Transgêneros - LGBT). O descumprimento de tais proibições é numeroso e diário. Contudo, a ineficácia das proibições (e a insistência nelas como única forma de lidar com a questão) não leva a um debate público amplo, aberto e racional sobre tais práticas e as consequências do proibicionismo. 
digitais dos próprios adolescentes ou dos professores/educadores, como jogos eletrônicos em celulares, conversas em redes sociais, vídeos no YouTube etc., sejam experiências oferecidas pelos adultos, tais como jogos e consoles aos quais os adolescentes não têm acesso, aplicativos e sites desconhecidos por eles, oficinas de produção de mídias, como edição de vídeos, construção de aplicativos, robótica, enfim, aquilo que estiver ao alcance da instituição para ampliar os horizontes de práticas digitais dos adolescentes, são momentos que recriam o ambiente informal do cotidiano e nos quais os adolescentes mais se expressam. Essa perspectiva de formação partindo das práticas digitais de lazer significativas para os sujeitos é central na proposta que aqui apresentamos.

Com essas experiências, podemos, então, compreender melhor questões como: $\mathrm{O}$ que mais interessa aos adolescentes e que sites de redes sociais são mais acessados? Quem são os amigos on-line? Quais são os assuntos das conversas quando acessam? Quais são os jogos eletrônicos preferidos, com quem se joga, em que plataforma se joga? Quais aplicativos e sites são mais utilizados para ouvir música, ver vídeos e filmes, ler e escrever fanfics, fazer pesquisas etc.? O que acontece ao redor de suas práticas digitais: sociabilidade, compartilhamento, isolamento? Por que procuram as práticas digitais em diferentes espaços sociais? O que buscam, aprendem e estudam nas práticas digitais? Quais são as oportunidades e os riscos das práticas digitais observadas? Quais as diferenças entre as práticas digitais dos adolescentes e dos adultos? Quais são as oportunidades ainda não apropriadas pelos adolescentes tendo em vista questões socioeconômicas ou culturais?

Para se ter acesso ao que pensam os adolescentes sobre essas questões, bem como às suas habilidades, dúvidas e dificuldades, mais do que fazer longos interrogatórios, é interessante estabelecer uma relação de confiança, envolvimento e diálogo, de maneira que eles percebam que as informações que são compartilhadas enquanto se realizam as práticas digitais não serão utilizadas para estigmatizá-los, prejudicá-los ou constrangê-los. De modo geral, na pesquisa os adolescentes mostraram-se muito dispostos a contar suas histórias, desde que entendessem que não haveria riscos para eles, como afirmou certa vez a aluna Solange (12 anos): "Professor, eu só conto minhas histórias e mostro o que faço na internet para você e para minha tia. Eu não conto para meus pais porque eles não me entendem". 
Nos grupos de práticas digitais, nas rodas de conversa e nas oficinas, o problema quando nos aproximávamos não era a falta de assunto, pelo contrário, era o enorme desejo dos adolescentes de contarem suas histórias, o que geralmente significava que o tempo que passávamos juntos era curto demais para que todos se expressassem. Enfim, parafraseando Geertz (1989, p. 17), a proposta de letramento digital que aqui delineamos sugere, como ponto de partida, conquistar acesso ao mundo social e conceitual no qual vivem os adolescentes, "de forma a podermos, num sentido um tanto mais amplo, conversar com eles".

Uma vez estabelecido um ambiente de confiança e de troca de experiências inspirado na ideia de comunidade de práticas (LAVE, 1991), conforme forem surgindo histórias, conflitos, dúvidas, desejos, necessidades na relação com os adolescentes e com suas (assim como com as nossas) práticas digitais, podemos alimentar a reflexão com o adolescente tomando como base quatro aspectos conceituais do letramento digital: representação, linguagem, produção e audiência (BUCKINGHAM, 2010), além da proposta de animação cultural e da centralidade do lazer na cultura digital adolescente (MELo, 2006). A proposta de letramento digital pensada com base nessas concepções e dados da pesquisa que realizamos é sintetizada no Quadro 1.

Quadro 1 - Proposta de letramento digital

\begin{tabular}{|c|c|c|}
\hline \multirow[b]{2}{*}{ Perspectivas } & \multicolumn{2}{|c|}{ Compartilhar mídias e práticas digitais com os adolescentes para } \\
\hline & $\begin{array}{l}\text { a) Refletir sobre as mídias } \\
\text { e as práticas digitais e sua } \\
\text { relação com o mundo }\end{array}$ & $\begin{array}{l}\text { b) Refletir sobre a adolescência em } \\
\text { si tomando como base as práticas } \\
\text { digitais }\end{array}$ \\
\hline Representação & $\begin{array}{l}\text { Qual a representação de mundo } \\
\text { das mídias acessadas pelos } \\
\text { adolescentes? }\end{array}$ & $\begin{array}{l}\text { Como as mídias representam a } \\
\text { adolescência? Como os adolescentes } \\
\text { representam a si mesmos nas mídias? O } \\
\text { que os adolescentes aprendem com e nas } \\
\text { mídias? Como analisar criticamente as } \\
\text { mensagens das mídias? }\end{array}$ \\
\hline Linguagem & $\begin{array}{l}\text { Que tipo de linguagem é } \\
\text { utilizada nas mídias digitais } \\
\text { dos/para adolescentes? Que } \\
\text { tipo de linguagem é utilizada } \\
\text { nas mídias acessadas pelos } \\
\text { adolescentes? }\end{array}$ & $\begin{array}{l}\text { Que mídias e linguagens midiáticas } \\
\text { o adolescente domina? Por quais se } \\
\text { interessa? Como dominar outras mídias e } \\
\text { linguagens? Como o componente afetivo é } \\
\text { utilizado para vender ideias e produtos? }\end{array}$ \\
\hline Produção & $\begin{array}{l}\text { Quem produz as mídias e com } \\
\text { quais interesses? }\end{array}$ & $\begin{array}{l}\text { Como se pode produzir as próprias mídias? } \\
\text { Com quais interesses? }\end{array}$ \\
\hline
\end{tabular}


(...continuação)

\begin{tabular}{|l|l|l|}
\hline Audiência & $\begin{array}{l}\text { A quem se direcionam as } \\
\text { diferentes mídias? }\end{array}$ & $\begin{array}{l}\text { Que audiência os adolescentes imaginam } \\
\text { atingir? Quais audiências não imaginadas } \\
\text { acessam as produções dos adolescentes? } \\
\text { Como gênero, classe social e meio urbano/ } \\
\text { rural influenciam o consumo digital? }\end{array}$ \\
\hline $\begin{array}{l}\text { Relação com as } \\
\text { mídias e com } \\
\text { outros sujeitos }\end{array}$ & $\begin{array}{l}\text { Quais os sentidos das } \\
\text { práticas digitais? Quais são as } \\
\text { sociabilidades nas e ao redor } \\
\text { das mídias digitais? }\end{array}$ & $\begin{array}{l}\text { Qual a relação dos adolescentes com as } \\
\text { mídias? Qual a relação dos adolescentes } \\
\text { com outros adolescentes com e sem as } \\
\text { mídias? Qual a relação dos adolescentes } \\
\text { com adultos e crianças por meio das } \\
\text { mídias? }\end{array}$ \\
\hline Lazer & $\begin{array}{l}\text { Qual a relação entre lazer e } \\
\text { práticas digitais? }\end{array}$ & $\begin{array}{l}\text { De que forma os adolescentes estão } \\
\text { apropriando-se de práticas digitais como } \\
\text { práticas de lazer? Qual a relação entre } \\
\text { práticas digitais e outras práticas de lazer? }\end{array}$ \\
\hline $\begin{array}{l}\text { Oportunidades e } \\
\text { riscos }\end{array}$ & $\begin{array}{l}\text { Quais oportunidades e riscos } \\
\text { as mídias oferecem para os } \\
\text { adolescentes? }\end{array}$ & $\begin{array}{l}\text { Como os adolescentes lidam com } \\
\text { oportunidades e riscos das práticas digitais? } \\
\text { Como é possível ampliar oportunidades e } \\
\text { diminuir riscos? Que outras oportunidades } \\
\text { podem ser criadas? }\end{array}$ \\
\hline
\end{tabular}

Elaboração dos autores.

Em um constante vaivém entre práticas digitais e questões para reflexão, as perguntas orientadoras levantadas seriam uma exposição conceitual (flexível) utilizada para orientar as conversas com os sujeitos em formação. Prática e reflexão não seriam, então, dois momentos separados no tempo, mas interligados e simultâneos. Insistimos que tais reflexões seriam sempre ancoradas na imersão em experiências divididas com e entre os adolescentes na instituição educativa ou narradas por eles, evitando-se discussões abstratas, trazidas artificialmente pelo professor/ educador e sem vínculo com o cotidiano e com as práticas sociais dos adolescentes. As respostas às questões apresentadas no quadro (e outras, nascidas dos próprios adolescentes ou das práticas compartilhadas) são múltiplas e, considerando-se a enorme probabilidade de se ter diferentes graus de intimidade com as mídias digitais e de conhecimento de mundo, surgirão pontos de vista conflitantes, enriquecendo o debate, mas também levando à necessidade, em alguns momentos, de sínteses, que podem vir dos adolescentes, dos adultos ou do confronto com a produção acadêmica sobre o assunto.

Com práticas digitais e reflexões compartilhadas, histórias, conflitos, dúvidas e desejos revelados, é possível imaginar demandas vindas 
dos adolescentes por novos temas para conversas, novas práticas e/ou oficinas de aprendizagem, como operação de softwares e aplicativos, dimensão técnica dos dispositivos, edição de vídeos, estudo de fake news, criação de aplicativos e jogos, experimentação de práticas desconhecidas, entre outras. Ao mesmo tempo, pode-se investir na produção de sites, vídeos, grupos em sites de redes sociais etc. que permitam compartilhar as experiências vividas e os conhecimentos construídos por aquele grupo. Essas oficinas de aprendizagem e práticas de produção devem, sempre que possível, ser orientadas por adolescentes da própria instituição, uma vez que provavelmente haverá alguns deles com habilidades especiais em relação às mídias digitais. Esse movimento de construção de conhecimento pelas habilidades distintivas dos próprios pares, ou de outros adolescentes, jovens e adultos da comunidade, é importante por empoderar não só os adolescentes, mas também a comunidade em que vivem.

\section{Considerações finais}

Neste texto, fundamentados em dados de pesquisa, defendemos a ideia de que, mais que nativos digitais, os adolescentes são brincantes digitais, bem menos letrados ou fluentes nas mídias digitais do que se tem assumido e não muito distantes qualitativamente dos interesses, habilidades e práticas digitais dos adultos que os cercam (BUCKINGHAM, 2006).

Nesse sentido, apresentamos uma proposta de letramento digital que, partindo das experiências nas quais os adolescentes estão imersos, pode contribuir para formar cidadãos mais capazes de, ao mesmo tempo em que se apropriam lúdica, criativa e criticamente das mídias digitais em práticas de lazer, ampliar as oportunidades e reduzir as limitações e os riscos associados a essas práticas. Entendemos que é extremamente relevante o enfrentamento, pela família e pela sociedade (incluídas as políticas públicas) e, em particular, por escolas e projetos sociais, da questão do letramento digital no intuito de possibilitar aos adolescentes aprenderem não só a lidar tecnicamente com as mídias digitais, mas também a usufruir, analisar, criticar e agir conscientemente perante as situações sociais criadas pelas práticas digitais. Algumas dessas medidas vêm sendo defendidas pelos movimentos sociais ligados aos direitos humanos e à democratização da comunicação (ARBEx JR., 2003).

Inspirados em Albury (2017), defendemos a ideia de que, seja em relação a jogos, sites de redes sociais, fake news, busca de informações, 
produção midiática ou qualquer outra prática digital, precisa-se investir mais na valorização das oportunidades e dos direitos digitais na perspectiva do letramento digital, ou seja, direito a acessar e aproveitar o máximo da cultura digital, seja como consumidor ou produtor de bens e cultura, além de também questionar a insistência em um modelo negativo de abordagem da relação entre adolescentes e práticas digitais. Condenar, proibir, negar, dificultar ou ignorar as práticas digitais dos adolescentes parece um caminho equivocado na formação de sujeitos intensa e inevitavelmente imersos na cultura digital.

\section{Referências}

Albury, K. Just because it's public doesn't mean it's any of your business: adults' and children's sexual rights in digitally mediated spaces. New Media and Society, Chicago, v. 1, n. 13, p. 713-725, 2017.

Arbex JR., J. Uma outra comunicação é possível (e necessária). In: MoraEs, D. (Org.). Por uma outra comunicação: mídia, mundialização cultural e poder. Rio de Janeiro: Record, 2003. p. 385-400.

Boyd, D. It's complicated: the social lives of networked teens. New Haven: Yale University Press, 2014.

Buckingham, D. Is there a digital generation? In: Buckingham, D.; Willett, R. (Eds.). Digital generations: children, young people and new media. New Jersey: Erlbaum, 2006.

Buckingham, D. Cultura digital, educação midiática e o lugar da escolarização. Educação e Realidade, Porto Alegre, v. 35, n. 3, p. 37-58, set./dez. 2010. Disponível em: <http://www.ufrgs.br/edu_realidade>. Acesso em: 15 nov. 2015. Buckingham, D. Defining digital literacy: what do young people need to know about digital learning. Nordic Journal of Digital Literacy, Norway, n. 4, p. 21-34, 2016.

Buckingham, D.; Burn, A. Game literacy in theory and practice. Journal of Educational Multimedia and Hypermedia, Waynesville, v. 16, n. 3, p. 323, 2007.

Buzato, M. E. K. Entre a fronteira e a periferia: linguagem e letramento na inclusão digital. 2007. Tese (Doutorado) - Universidade Estadual de Campinas (UnicAmP), Campinas, 2007.

Carnicelli, S.; Mcgillivray, D.; Mcpherson, G. Concluding remarks. In: Carnicelli, S.; Mcgillivray, D.; Mcpherson, G. (Eds.). Digital leisure cultures: critical perspectives. New York: Routledge, 2017.

CARvalho, O. B. M. Jogar, encontrar amigos ou espalhar o currículo por aí: uma etnografia na lan house e no Telecentro. 2010. 180p. Dissertação (Mestrado) - Universidade Federal Fluminense, Niterói, 2010. 
Dores, A. P. Proibicionismo e anomia: uma apresentação do conceito estados-de-espírito. Lisboa: Instituto Universitário de Lisboa, 2003. (Prova de Agregação). Disponível em: <https://repositorio.iscte.pt/handle/10071/6799>. Acesso em: 28 abr. 2018.

FARIA, E. L. A aprendizagem da e na prática social: um estudo etnográfico sobre as práticas de aprendizagem do futebol em um bairro de Belo Horizonte. 2008. 229f. Tese (Doutorado em Educação) - Universidade Federal de Minas Gerais, Belo Horizonte, 2008.

Geertz, C. A interpretação das culturas. Rio de Janeiro: LTC, 1989.

LAVE, J. Situating learning in communities of practice. In: Resnick, L. B.; Levine, J. M.; Teasley, S. D. (Eds.). Perspectives on socially shared cognition. Washington, DC: American Psychological Association, 1991. p. 63-82.

LiVINGSTONE, S. Internet literacy: a negociação dos jovens com as novas oportunidades on-line. Matrizes, São Paulo, ano 4, n. 2, p. 11-42, jan./jun. 2011.

Melo, V. A. A animação cultural. Campinas: Papirus, 2006.

Prensky, M. Digital natives, digital immigrants, part II: Do they really think differently? On the Horizon, United Kingdom, v. 6, p. 1-9, dez. 2001.

Rosado, L. A. S.; Tomé, V. M. N. As redes sociais na internet e suas apropriações por jovens brasileiros e portugueses em idade escolar. Revista Brasileira de Estudos Pedagógicos, Brasília, v. 96, n. 242, p. 11-25, 2015.

Santos, S. O. O escolar e a televisão. 1977. Dissertação (Mestrado) Universidade de São Paulo (USP), São Paulo, 1977.

SCOlari, C. A. Transmedia literacy in the new media ecology: white paper. Barcelona: Universitat Pompeu Fabra; Departament de Comunicación, 2018. Disponível em: <repositori.upf.edu>. Acesso em: 2 abr. 2018.

Simmel, G. The sociology of sociability. American Journal of Sociology, Chicago, v. 55, n. 3, p. 254-261, 1949.

Simmel, G. Sociabilidade: um exemplo de sociologia pura ou formal. São Paulo: Ática, 1983. p. 165-181.

Valkenburg, P. M. et al. Developing and validating the perceived parental media mediation scale: a self-determination perspective. Human Communication Research, [S.1.], v. 39, n. 4, p. 445-469, 2013.

Veissière, S. P. L.; STENDEL, M. Hypernatural monitoring: a social rehearsal account of smartphone addiction. Frontiers in Psychology, Lausanne, v. 9, n. 141, p. 1-10, fev. 2018. 



\title{
HIP-HOP \& EDUCAÇÃO: UMA BATALHA QUE SE VENCE COM DIVERSÃO
}

\author{
Cristiane Correia Dias (b-girl Cris) \\ Daniel B. O. Tejera (Daniel Garnet) \\ Elaine Cristina Moraes Santos
}

A primeira vez que estive com alunos(as) da Zona Leste para minha primeira aula de hip-hop foi uma experiência traumática, principalmente pelo modo como os(as) professores(as) reagiam ao caos iminente na sala de aula. Todos estavam muito exaltados, e o máximo que eu consegui fazer foi observar a cena desastrosa que ali se apresentava da realidade escolar. Minha memória trouxe a recordação de quando eu estava no $7^{\circ}$ ano do ensino fundamental. Aprendi a ler e a escrever bem cedo, mas desisti de tirar boas notas depois de ter sido acusada muitas vezes pelos(as) meus(minhas) professores(as) de colar na prova. Lembrei que nessa fase fui uma adolescente rebelde e só retomei meu gosto pela leitura quando, um dia, fiquei de castigo, separando os livros que iriam compor a nova biblioteca da escola. Na saída, roubei um livro, pois me vi atraída pela capa, mas como a linguagem era difícil e meus pais eram analfabetos não consegui acessar aquele conhecimento. Essa lembrança me fez retornar para meu segundo dia de trabalho com aqueles(as) alunos(as) de uma outra forma. Preparei uma atividade chamada Game over: entre jogar e pesquisar ${ }^{1}$, pois a primeira impressão que me deu, quando vi o olhar daqueles(as) professores(as)

1 Atividade criada para que a pesquisadora entrasse em contato com o universo da classe, pois a aula anterior era na sala de informática e havia muita dificuldade de mudar de espaço, então a decisão foi iniciar seu projeto por meio de pesquisa nas redes sociais. 
e alunos(as), foi de como se todos estivessem em um jogo perdido. Então vi a sala de informática como uma possibilidade "de passar de fase e enfrentar o chefão" e deixei isso claro: "Vocês sabiam que estão em um jogo, né? Pois bem, nesse jogo eu não quero perder, vocês querem?". Talvez naquele momento eles não soubessem exatamente de que jogo eu estava falando, mas gostaram da ideia de pesquisar na internet a história do hip-hop. Embora cada conhecimento novo adquirido virtualmente disputasse com o desejo dos(as) alunos(as) em se manterem fixados em suas redes sociais, aos poucos, cada novo elemento e curiosidade daquela cultura ia dando um novo sentido para a sala de aula. Eles(as) entraram em contato com uma musicalidade que nomeava aquele jogo perverso que os colocava na condição de perdedores e, consequentemente, encontraram no corpo um novo modo de enfrentar aquela batalha.

Cristiane Correia Dias

B-girl e hip-hopper/ Mestranda da Faculdade de Educação da Universidade de São Paulo (FE-USP) Projeto Breaking e suas origens ${ }^{2}$

Eu não imaginava que o desejo de juntar profissão e lazer seria tão literal a ponto de eu me tornar professor de rap no ensino fundamental! Cheguei na classe rimando. Eles ouviram estáticos, nem pareciam os mesmos que estavam minutos antes gritando e trocando ofensas. Após as palmas, me apresentei e disse que a partir dali trabalharíamos dentro de uma nova proposta: iríamos tanto estudar textos que eram letras de rap, como usar os textos tradicionais para produzir novas letras com direito a um fundo musical. Um dia marcante foi quando, durante os estudos de uma obra infantojuvenil, cada grupo ficou responsável por criar um rap sobre um personagem do texto. A apresentação foi uma batalha de rima, cada grupo cantou sua produção, a classe foi à loucura! Senti que era o

2 Hiphopnagô: letramentos rítmicos e sonoros. São Paulo, 2018. 17min. Disponível em: $<$ https://youtu.be/UP1AV56NWN8>. Acesso em: 12 maio 2018. Trata-se da continuidade do trabalho com alunos do $8^{\circ}$ ano do ensino fundamental. Essa docência compartilhada aconteceu entre a disciplina de língua portuguesa, com a professora Rosana Divino, a mestranda e professora de breaking Cristiane Dias e a mestranda e musicista Maria Teresa Loduca, na Emef Saturnino Pereira. 
momento de introduzir a nova temática, parágrafos viraram versos, leituras passaram a ser declamações, e apresentações se transformaram em performances. Alunos(as) que até então não produziam passaram a escrever e a se expressar. Para cada estrofe que encontrava uma batida, saltos e sorrisos aconteciam expressando a alegria de quem atingiu um objetivo proposto com muito esforço e dedicação, alegria compartilhada por uma classe ansiosa para ver os amigos se superando, dando literalmente um show, a literatura infantojuvenil passou a dar lugar para o conhecimento sobre outras histórias afro-brasileiras, terminando na autobiografia individual de cada aluno. Contar a própria história nunca foi uma atividade tão coletiva, pois, fora as conhecidas mazelas dos não dominantes, aprendemos juntos a nos reconhecer como parte de uma história de luta. A vergonha de ser subalternizado por anos deu lugar ao orgulho de ter resistido por séculos. Todos nós estávamos mais do que contando a nossa história individual, estávamos contanto e cantando uma única história coletiva, porém agora com nome, data, endereço, cultura, motivações e sonhos. Debatemos controvérsias de histórias contadas ao inverso, cantando e ampliando nosso universo, dando vida às nossas conversas, com versos.

Daniel Garnet MC e hip-hopper/ Pesquisador da Fundação de Amparo à Pesquisa do Estado de São Paulo (FAPESP)/FE-USP Projeto Conversas com versos ${ }^{3}$

No dia em que pedi aos(às) alunos(as) que assistissem ao clip Serviço de preto, de Daniel Garnet e Peqnoh, pela primeira vez em sala de aula foi possível perceber a inquietação de corpos e mentes daqueles(as) jovens, as cabeças se movimentando conforme o som e o ritmo da canção. Trabalhamos essa música durante algumas atividades e, nesse processo, tivemos a oportunidade de explorar os limites e as possibilidades que a internet proporciona em termos de

3 Conversas com versos: o rap na disciplina de história como meio de estudo autobiográfico. São Paulo, 2018. 18min. Disponível em: <https://youtu.be/Gco8UXnemAA>. Acesso em: 12 maio 2018. Trata-se de um vídeo síntese do projeto de docência compartilhada realizado em parceria com o professor de história Sidnei na Escola Roberto Mange, com alunos do $7^{\circ}$ ano. 
experiência compartilhada para que pudéssemos tratar da questão étnico-racial e fomentar reflexões críticas sobre o uso dos aparelhos. Em parceria com um dos compositores da música, Daniel Garnet, os(as) adolescentes tiveram a oportunidade de estabelecer uma comunicação virtual e presencial com o rapper. Primeiramente, ele foi estabelecendo um diálogo com os(as) alunos(as) através de um vídeo, contando a história da música e o processo de criação da letra, e no final do módulo chamamos o rapper para uma aula presencial. Na medida do possível, tentamos explorar os sentimentos despertados em cada experiência, buscando fazer com que eles(as) discernissem que o vídeo gravado e a presença real do rapper na sala de aula eram meios de se estabelecer uma comunicação, mas que não era a mesma coisa e não produzia o mesmo efeito. No contato feito virtualmente, eles(as) ficaram surpresos(as) ao ver o rapper se dirigir diretamente à turma, dedicando um pouco de seu tempo para gravar um vídeo especialmente preparado para eles(as). Isso contribuiu para que os(as) alunos(as) quisessem saber mais sobre o cantor. Entretanto, esse primeiro contato não se compara com a interação estabelecida no dia em que o rapper apareceu na sala de aula. Os(As) alunos(as) ficaram encantados ao terem à sua frente um músico que eles(as) tinham aprendido a admirar. Foi uma experiência interessante na qual os(as) adolescentes puderam perceber as possibilidades reais e virtuais de se aproximar de pessoas ou conteúdos diversos.

Elaine Cristina Moraes Santos Psicóloga/Doutoranda (FE-USP) Projeto Griot Digital ${ }^{4}$

Os relatos anteriores referem-se a diferentes experiências de docência compartilhada ${ }^{5}$ desenvolvida durante três anos entre professores(as),

4 GRIOT Digital: ressignificando a ancestralidade na educação. São Paulo, 2018. $11 \mathrm{~min}$. Disponível em: <https://youtu.be/E2B8XjLXp0c>. Acesso em: 12 maio 2018. Trata-se de um vídeo síntese do projeto de docência compartilhada realizado em parceria com a professora Vilma Nardes na Escola Roberto Mange com alunos do $8^{\circ}$ e $9^{\circ}$ anos.

5 A docência compartilhada foi o modelo pedagógico adotado nesta pesquisa, baseado na pedagogia hip-hop de Marc L. Hill (2014), que consistia em uma aula ministrada conjuntamente por dois professores(as), de maneira que pudesse estabelecer novas estratégias de ensino lançando mão do diálogo entre culturas populares urbanas e o 
arte-educadores(as) e pesquisadores(as). Essa vivência deu-se em duas escolas da periferia de São Paulo, no âmbito de uma pesquisa em políticas públicas intitulada $O$ ancestral e o contemporâneo nas escolas: reconhecimento e afirmação de histórias e culturas afro-brasileira (FAPESP, 2015/50120-8 $)^{6}$, coordenada pela professora doutora Mônica Guimarães Teixeira do Amaral, da FE-USP. Lançando mão de diferentes abordagens metodológicas, construímos com os(as) professores(as) e alunos(as) uma série de abordagens didáticas inovadoras que pôde ser incluída no currículo escolar - envolvendo música, dança, teatro, capoeira, hip-hop e outras manifestações estéticas de matriz afro-brasileira - com base nas Diretrizes Curriculares Nacionais para a Educação das Relações Étnico-Raciais e para o Ensino de História e Cultura Afro-Brasileira e Africana.

Procuramos contemplar as diretrizes curriculares nacionais para a educação básica relacionadas à efetivação da lei n. 10.639/20037 , que tornou obrigatória a inclusão da história da África e das culturas afro-brasileiras no currículo das escolas públicas e privadas de ensino fundamental e médio. Nosso propósito foi construir uma experiência educacional possível de articular os saberes dos(as) alunos(as) com os conhecimentos historicamente acumulados pela cultura negra, para que houvesse uma formação étnica, ética e estética baseada em valores e atitudes que pudessem reverberar no conjunto da sociedade.

Contudo, embora nossas experiências tenham procurado dialogar com o currículo escolar existente, valorizando seus avanços e

ensino formal. No caso particular desta pesquisa, um(a) professor(a) responsável pela disciplina ministrada dividia o espaço com um(a) pesquisador(a) e/ou artista, cujo objeto de trabalho estava relacionado de alguma forma com manifestações culturais africanas e/ou afro-brasileiras, como o teatro negro, a capoeira, o maculelê etc. Este capítulo teve como base a parceria de pesquisadores(as) do hip-hop, da cultura negra e de suas possíveis articulações com as mídias digitais, em parceria com professores(as) de história, português, educação física, leitura e informática.

6 Entre as pesquisas anteriores realizadas por Mônica Guimarães Teixeira do Amaral em escolas públicas de São Paulo, temos o Programa de Melhoria do Ensino Público, sob o título Culturas juvenis x cultura escolar: como repensar as noções de tradição $e$ autoridade no âmbito da educação? (FAPESP, 2006/2008) e a pesquisa de políticas públicas sob o título Rappers, os novos mensageiros urbanos na periferia de São Paulo: a contestação estético-musical que emancipa e educa (FAPESP, 2010/2014).

7 A lei n. 10.639/2003 foi promulgada pelo Governo Lula, como resultado das lutas de movimentos sociais, alterando a lei n. 9.394/1996, referente às diretrizes e bases dos documentos nacionais de ensino. 
reformulações, nossa proposta metodológica pautou-se por uma epistemologia atenta à realidade local, individual e coletiva, em particular da juventude afrodescendente. Levando em consideração os marcadores sociais que definem as diferentes "juventudes" em identidade, gênero, sexualidade, raça e classe, esta pesquisa traz à tona a gramática existente no contexto da periferia, com seus hibridismos e deslocamentos.

Desse modo, buscamos ancorar as vivências individuais e coletivas de cada integrante em um processo investigativo e interpretativo que explora as potencialidades narrativas da cultura popular como algo que possibilita apontar para um novo registro da história que se encontra além do conhecimento normalmente apresentado nos livros didáticos. Nesse sentido, o tipo de letramento enfatizado pela cultura ocidental ganha outra dimensão quando passa a incorporar o corpo, o ritmo, a musicalidade, a memória, a oralidade, a imagem e outros elementos que ressignificam a experiência dos povos subalternizados historicamente. Entre as mais diversas abordagens culturais e artísticas trabalhadas por nosso grupo de pesquisa, gostaríamos de ressaltar a eficácia evidenciada na metodologia hip-hop, enquanto uma proposta educativa capaz de mobilizar o coração, a mente e o corpo da juventude periférica (AMARAL et al., 2018).

O movimento hip-hop surgiu na década de 1970 com a iniciativa de jovens negros e imigrantes caribenhos, moradores da periferia de Nova York, Estados Unidos, em um contexto urbano de desemprego, crise industrial e aumento da violência. Esse movimento emergiu em meio ao caos e ao abandono social no sul do Bronx, quando então a juventude enfurecida se reunia para acerto de contas após o assassinato do jovem Black Benjy, um dos líderes da gangue Guetto Brother. Em 1971, esse conflito culminou em um dos maiores tratados de paz que a cidade de Nova York já havia presenciado, ao passo que a sociedade, o governo e a mídia aguardavam um massacre juvenil. Um dos acordos feitos entre a comunidade foi permitir a circulação dos(as) jovens entre os bairros demarcados pelas gangues, transformando a violência entre eles em disputas sadias. A proposta era substituir os conflitos por confrontos lúdicos, com dança, música, poesia, arte plástica e reflexão. Em 1973, o DJ Kool Herc organizou para sua irmã Cindy Campbell uma grande festa de aniversário, considerada como o primeiro evento de hip-hop. Herc tornou-se um dos principais organizadores de festas de rua, mais conhecidas como block parties. Ele foi responsável por contribuir para que 
as "rixas" se convertessem em duelos envolvendo diferentes expressões artísticas reunidas pelo DJ Afrika Bambaataa. Os elementos dessa cultura atualmente são: o MC, o DJ, o breaking, o grafitti, a moda hip-hop, o empreendedorismo do hip-hop, o beatbox e o conhecimento, que dá "liga" a todos os outros e produz sentido a cada seguimento artístico dentro do hip-hop, proporcionando o engajamento político, sociocultural e histórico que motiva os participantes a pensar e executar ações em busca de sentido para a vida.

O potencial de socialização da cultura hip-hop expandiu-se a partir de 1980, passando a orientar boa parte da nova geração com seus movimentos estéticos e práticas corporais, que traduzem uma nova identidade e uma nova leitura de mundo. Seu significante global e local tem sido capaz de conectar pessoas em diversos lugares e espaços mediante mútuas identificações relativas à classe, cor e outras questões que trazem à tona vozes e corpos, antes em condição anônima e silenciada nas periferias.

Asante (1980) apresenta uma teoria sobre afrocentricidade valendo-se da revolução desenvolvida pelo hip-hop que conecta culturas de expressão negra com um discurso subversivo que remete, por sua vez, à diáspora africana. Experiências, memórias e tradições de pessoas comuns ligam-se àquilo que Bakhtin chama de "o vulgar - o popular, o informal, o lado baixo, o grotesco" (apud Hall, 2006, p. 152). Com um discurso de afirmação étnico-racial, a manifestação dessa cultura aparece no Brasil entre as décadas de 1980 e 1990, difundindo-se em todos os estados e, principalmente, em suas periferias como uma manifestação popular, juvenil, sociocultural, política e também educacional. Em um jogo de desafio e de disputa presente em cada uma de suas expressões artísticas, trabalham-se perigos imaginários, medos reais, prazer, tristeza e alegria. Muitas dessas sensações, em grande parte reprimidas no cotidiano, encontram um espaço e momento protegidos pela esfera do lazer para se expressarem, conforme aponta Marcellino (2002). De acordo com esse autor, o lazer advém de um contexto urbano desenvolvido na sociedade moderna, pela diferenciação entre trabalho e descanso. No entanto, a relação entre lazer e sociedade é dialética e ultrapassa a dimensão da diversão e da pausa. A experiência que pode ser adquirida nesses espaços provoca rupturas morais e culturais na estrutura que determinou a ordenação espaço-temporal da sociedade contemporânea.

O sociólogo Dumazedier (1972) traz a sua teoria "3D", atribuindo ao lazer três perspectivas de atividade: divertimento, descanso e 
desenvolvimento. Na esteira desse pensamento, inúmeras possibilidades podem ser pensadas nesse tripé. Embora o sistema educacional, na maior parte das vezes, ainda não reconheça a potência desse entrelaçamento, os espaços de lazer têm progressivamente evidenciado de maneira espontânea, crítica e criativa o desenvolvimento de uma juventude, em sua maioria negra, envolvida no processo de ruptura e denúncia contra sua condição de marginalização histórica. As inovações tecnológicas também propõem um novo modo de pensar o lazer, já que a dimensão do descanso vem assumindo, cada vez mais, uma nova configuração que mescla o tempo produtivo com o tempo ocioso. $\mathrm{O}$ acesso permanente aos cativantes recursos audiovisuais, canais interativos e navegadores virtuais, coloca-nos diante de um imperativo social de mobilidade e conexões. Por isso o modelo tradicional escolar, ainda preso a um tempo determinado por intervalos em um lugar delimitado por paredes, grades e fechaduras, entra em choque com um novo modelo de subjetividade juvenil.

Para Chaui (2003), formação significa promover uma relação com o tempo, ou seja, introduzir no aluno o passado de sua cultura, despertando-o para questões que esse passado engendra no presente. Assim, a manifestação artística do hip-hop é capaz de promover um tipo de conhecimento que se relaciona com a realidade existente nas periferias, e sua história mostra uma diversidade de movimentos de transformação que dão destaque e possibilidade de reconhecimento ao(à) jovem da favela. Conforme Diaz (2015, p. 174), “a cultura e mídia do hip-hop no currículo pode servir como catalisador e ferramenta para fortalecer o educar", garantindo o diálogo entre a educação, a cultura e o lazer como uma estratégia pedagógica que desperta o interesse e o engajamento da juventude dentro do universo escolar.

Nessa perspectiva, pretendemos demonstrar, em concordância com Hill (2014, p. 39), "como as identidades de estudantes são renegociadas, quando a cultura hip-hop se torna parte do currículo oficial da sala de aula”. O hip-hop permite que os(as) educadores(as) reconheçam a origem e a importância dessa juventude em seu habitat, enquanto um espaço geopolítico criado para afastar a população negra e pobre dos grandes centros econômicos denominado por Sabotage de "Um bom lugar":

8 "Um bom lugar" é o título de uma canção do rapper Sabotage, lançada no álbum Rap é compromisso, em 2000. 
Pisca e clack, enlouquece, breck

Só de arma pesada, inferno em massa

Vem violentando a minha quebrada, basta!

Eu registrei, vim cobrar, sangue bom

Boa ideia quem tem, não vai tirar a ninguém

Meditei, mandando um som com os irmãos da Fundão

Volta ao Canão se os homens vim disfarça o grandão

Rap é o som, embora lá no morro, só louco,

A união não tem fim...

[SABotAGe, 2000]

Sabotage era MC e ativista do hip-hop. Nasceu em São Paulo e morava na favela do Canão, no Brooklin, Zona Sul de São Paulo, um lugar cheio de tensões, dividido entre a miséria extrema da favela e a riqueza dos prédios e casas de luxo ao redor. Foi entre o lixo e o luxo que cresceu o jovem negro Mauro Mateus dos Santos, posteriormente apelidado de Sabotage. As contradições e tensões retratadas em suas músicas foram convertidas na trilha sonora de sua vida, que terminou aos 29 anos, quando o rapper finalmente começava a ser reconhecido e respeitado profissionalmente no meio artístico. Sabotage foi atingido por quatro tiros em um cenário que apresenta exatamente aquele que inspirava suas canções: a favela. Considerado atualmente como um dos maiores ícones do rap nacional, sua identidade continua sendo reverenciada com características próprias que inspiram inúmeras outras comunidades cujas realidades se conectam de alguma forma com a sua história. No entanto, o contraste na vida de Sabotage, músico que encontrou espaço de voz nas mídias, no cinema, na arte e na televisão para falar do perigo iminente vivenciado na favela, é precocemente silenciado por uma violência óbvia, retratada em números, relativa a uma guerra que pode ser identificada pela cor e pelo gênero. De acordo com Meirelles e Athayde (2014), no levantamento estatístico realizado pelo Mapa da violência, entre os anos de 1980 e 2014, a maior parte das vítimas assassinadas por arma de fogo foram homens e negros entre 14 e 29 anos. A média nacional atingiu o percentual de $94,3 \%$ e a participação de jovens afro-brasileiros nestes crimes foi de $50 \%$.

A luta pela sobrevivência é constante na favela e em ambientes que ficam à margem da sociedade, por isso as expressões juvenis manifestadas nesses contextos nos ensinam a como enfrentar o campo de batalha vivenciado atualmente nas escolas. Um jovem da favela que cresce com 
uma arma de fogo apontada para a sua cabeça e, mesmo assim, torna-se protagonista nesse cenário, reinventando um novo modo de ser, viver e empreender, nos oferece algumas pistas sobre como podemos enfrentar os desafios de uma educação pensada para o século xxi. A Carta Internacional de Educação para o Lazer enfatiza a importância de se pensar espaços interativos e cativantes dentro do currículo em todas as disciplinas como forma de atrair a atenção dos(as) alunos(as) às matérias e aos conteúdos formais da educação. Segue o que está documentado em seu item 2.2 (WLRA, 1993):

I. Detectar o potencial para o conteúdo de lazer que existe em cada matéria, currículo e atividades extracurriculares.

II. Incluir matérias apropriadas e relevantes para o estudo de lazer, tanto direta como indiretamente. Cada matéria deve ser enriquecida com conteúdo de lazer.

III. Incorporar o lazer em todas as atividades educacionais e culturais, dentro e fora da escola.

A carta tem como meta garantir a qualidade de vida também por intermédio do lazer, e como grande parte do nosso desenvolvimento se dá dentro de uma unidade escolar, esse espaço não pode ser desestimulante e penoso. Por isso, transformar os espaços educativos em um ambiente atrativo implica a inclusão de atividades lúdicas que despertem o interesse de aprender dos(as) jovens. Nesse sentido, propiciar experiências culturais de lazer dentro do currículo formal, com uma arte engajada politicamente, como é o caso do movimento hip-hop, pode redimensionar a formação pela perspectiva do prazer, que joga o sujeito no "coração da ação", com "atos de linguagem" evidenciados no corpo e na fala (Amaral; Dias; Tejera, 2018, p. 123). Nas batalhas de rima ${ }^{9}$, por

9 Duelo tradicional da cultura hip-hop, cujo rapper ou MC ataca o seu oponente verbalmente, criando versos elaborados de improviso, com base em seu conhecimento prévio, bem como aquilo que está acontecendo em tempo real, enquanto a batalha é travada. O filme 8 Mile (2002), teve uma grande importância na difusão dessa prática no Brasil, que a partir da organização de batalhas, como a Batalha do Real (Rio de Janeiro), a Batalha do Santa Cruz (São Paulo) e o Duelo de MC's (Belo Horizonte), passaram a ser vistas como um evento independente da cultura hip-hop, ou seja, passou a ser uma modalidade de evento de grande público, em que não necessariamente seus participantes são adeptos e/ou conhecedores do hip-hop como cultura e estilo de vida. 
exemplo, diferentes sentimentos podem ser evocados e às vezes colocados em contraste, dinamizando uma permissão imaginária que sugere a diversão, desencadeando atividades miméticas que se vão transformando em um processo de desenvolvimento e aprendizagem capaz de promover uma elaboração crítica da vida real.

No texto "A doutrina das semelhanças", Benjamin (1996) aproxima-se do pensamento aristotélico relacionando a mímesis ao jogo e ao aprendizado que desperta o conhecimento e o prazer de conhecer. $\mathrm{O}$ autor considera que há dois momentos de atividade mimética humana: o de reconhecimento e o de produção de semelhanças. Ambos os processos podem ser identificados nas brincadeiras infantis, quando a criança reage ao mundo mediante a criação e a imaginação lúdica sobre o que já existe. A capacidade mimética seria a possibilidade de transformar o que já existe com base em uma mediação simbólica, que não se reduz à imitação. Desse modo, a mímesis seria uma dimensão essencial do pensar, que se aproxima de maneira não violenta do objeto, ou seja, de uma forma que não o submete, explorando as possibilidades lúdicas em prol de um conhecimento que se baseia na experiência de cada indivíduo (GAGNebin, 1993).

$\mathrm{Na}$ tradição ateniense, uma das propostas educativas era cuidar da alma recorrendo a atividades artísticas, que de modo geral tinham uma representação mimética. Porém, Platão tentava domar a força das imagens impondo-lhes normas éticas e políticas, fazendo distinção entre realidade e ilusão, verdade e mentira, inaugurando a censura para tudo o que não se apresentava como autêntico. A concepção mimética do pensamento platônico está relacionada com a tradução e a reprodução de um paradigma ideal que exclui tudo o que é "demoníaco" ou "contaminado" (GAgnebin, 1993). Para Platão, a verdade era uma só, e a mímesis seria uma espécie de aparência que imitava o original, sob o risco de o representado substituir o representante (MATOs, 2001). Já na contramão de seu mestre, Aristóteles enfatizava a mímesis como parte da natureza e do aprendizado humano. Sua preocupação não era o que deveria ser representado, mas como era representado. Ainda que haja uma lógica normativa no pensamento aristotélico, o foco está na relação entre a imagem e o objeto como um momento de prazer, e não como uma possibilidade de perigo desviante da essência, conforme observara Platão. O lúdico, nesse caso, é introduzido como algo que estimula e encoraja o processo de conhecimento, mediante o reconhecimento de imagens que representam 
a realidade em sua aparência. Contrariando a ideia ocidental de aparência, enquanto um adjetivo negativo de superficialidade, que se opõe à qualidade da essência como aquilo que remete ao ser humano "profundo e verdadeiro", o jornalista e sociólogo brasileiro Muniz Sodré (2005) coloca a aparência como uma característica intrínseca às manifestações advindas da cultura negra. O “aparecer”, pelo viés manifesto em muitas culturas africanas, não significa oposição à essência ou algo relacionado à falsidade, mas sim à crença de uma verdade que não é única e absoluta. Nesse sentido, o termo é utilizado pelo autor com uma nova possibilidade de cultura e representa uma recusa à concepção universal da verdade veiculada pela cultura dominante.

Quase todas as sociedades humanas - se não todas - possuem atividades lúdicas equivalentes ao que chamamos de lazer, tais como: danças, confrontos simulados, exibições acrobáticas, musicais e cerimônias diversas, ou seja, atividades sociais que proporcionam uma espécie de renovação emocional com o equilíbrio em contraposição aos esforços e às pressões da vida cotidiana, com suas lutas e desafios reais, incluindo seus perigos, riscos e constrangimentos (Elias; DunNing, 1985).

Em “O mal-estar na civilização", Freud (1996) afirma que os homens são criaturas formadas por pulsões de vida e de morte, sendo esta última dotada de uma relevante dose de agressividade, também chamada de pulsões destrutivas, então dificilmente passíveis de serem interditadas e reprimidas, a não ser quando contidas pelo fortalecimento das pulsões de vida, o Eros. Isso quer dizer que é ingenuidade acreditar que uma organização social pode ser sempre pacífica ou livre da brutalidade humana; entretanto, também não significa afirmar que podem ser consentidas determinadas configurações de violência como fazendo parte das formações sociais. Nesse contexto, é importante registrar que a cultura/ civilização produz modos de eliminar e/ou limitar as moções agressivas e o embate lúdico presente nos elementos do hip-hop.

O hip-hop e suas expressões artísticas (breaking, DJ, MC e grafitti) evocam diferentes estados emocionais que são sentidos primeiramente no corpo. A relação do corpo com esse movimento cultural juvenil tem origem na reparação de uma atmosfera perigosa e agressiva que atingiu primeiramente os afro-americanos, hispânicos e imigrantes no contexto norte-americano. A festa de rua foi o espaço criado para transformar essas pulsões de morte em um hibridismo cultural urbano, caracterizado por música, dança, pintura e outras manifestações artísticas que permitiam 
"mexer os quadris" em um movimento corporal de contestação e diversão. O corpo do hip-hopper, ou seja, aquele que tem o hip-hop como parte integrante do seu habitus ${ }^{10}$, é um corpo que tem ritmo musical até no caminhar, é um corpo que, muitas vezes, mesmo fora das festas de rua anda com swing. O caminhar parece "balanceado" e o braço tem uma maneira específica de se mover, o modo de ficar em repouso e de sentar também tem um jeito despojado.

Além de se legitimarem pela maneira de vestir-se, de falar, entre outros modos, os jovens se reconhecem e se identificam com o outro por meio de gestos corporais. Assim, o dialeto corpóreo dos países que trazem em sua história a barbárie da diáspora do Atlântico e que sofre as marcas desse passado violento e racista carrega consigo um corpo impróprio, que encontra um lugar de reconhecimento e de igualdade dentro da cultura hip-hop. Nesse sentido, esse corpo torna-se um elemento ressignificador de uma afro memória que recorre a experiências ancestrais e contemporâneas no interior do que Osumaré (2015) denomina de marginalidades conectivas do hip-hop. Segundo a autora, esse processo se dá a partir de quatro significantes compartilhados - classe, cultura, opressão histórica e construção discursiva do status periférico - que se ligam a um conjunto de representações e elementos estéticos africanistas, simbolizados pelas culturas afro-americanas e latinas de uma população historicamente marginalizada, em busca de reconhecimento e igualdade. McLaren (1997) apresenta as lutas históricas dos afrodescendentes urbanos como verdadeiras zonas de contestação às práticas discursivas dominantes - e com a difusão dos meios de comunicação esse movimento de contracultura alcançou tamanha evidência como nunca antes imaginado. A velocidade com que suas danças, trajes, artes e músicas são compartilhadas e o alcance global que esses elementos exercem, mais do que indiscutíveis, são espantosos. Em 2015, um dos aplicativos de música

10 Falamos de habitus com base na definição de Bourdieu (2001), que é a incorporação de disposições que moldam o corpo como consequência de condições culturais e materiais, socializando o corpo ao seu grupo pertencente. Essas disposições são duradouras, geram e estruturam práticas incorporadas e inconscientes, consequentemente regularmente produzidas. A noção de habitus engloba o corpo. 
mais utilizados mundialmente, o Spotify, declarou o gênero rap como o mais ouvido no mundo na ocasião ${ }^{11}$.

No livro Um país chamado favela, Meirelles e Athayde (2014) apresentam uma pesquisa quantitativa denominada "Radiografias das favelas brasileiras", coordenada pelos mesmos autores, com realização pelo Instituto Data Favela em 35 cidades brasileiras. O resultado mostra um trabalho de campo que ouviu duas mil pessoas de 63 favelas no ano de 2013, servindo para mensurar o investimento econômico circulante nesses espaços, pela análise de seus comportamentos enquanto consumidores. $\mathrm{O}$ consumo apontado nesses espaços movimenta 63 bilhões de reais por ano. Segundo Meirelles e Athayde (2014, p. 12-13):

Os jovens e não apenas eles, as mulheres e não só elas, assumiram inédito protagonismo, inventando novas linguagens, transformando profundamente os templos herdados e os templos legados. A revolução religiosa está em curso, com muitas contradições, mas com inegável força renovadora. O funk está aí, as redes sociais estão ligando lan house, celulares, indivíduos e novas comunidades. Os sentidos de participação cidadã estão em efervescência constante. De tal modo, que o que hoje talvez seja permanente e comum às "favelas" são a impermanência e a desigualdade, o dinamismo e os surpreendentes protagonismos, com suas diferentes linguagens, disseminando uma nuvem bélica, febril, excitante, às vezes inquietante e perturbadora, tornando o futuro incerto, imprevisível, na exata medida em que a liberdade introduziu-se no processo, por meio de sujeitos que assumiram seu inusitado senso de cidadania criativa. Não há mais sossego. Não mais haverá o sossego que provém da paz dos cemitérios e da naturalização das desigualdades, dos estigmas e do racismo.

De acordo com Meirelles e Athayde (2014, p. 94), "78\% dos(as) jovens entre 16 e 29 anos são internautas" e estão multiconectados com seus notebooks, tablets, celulares e smartphones. Nota-se que o crescimento sociocultural e econômico das favelas por meio do protagonismo e da visão empreendedora e criativa de sua população desmitifica a visão

11 "Rap é o gênero mais ouvido do mundo, segundo Spotify". Billboard Brasil, São Paulo, 15 jul. 2015. Disponível em: <http://billboard.uol.com.br/noticias/rap-e-o-genero -mais-ouvido-do-mundo-segundo-spotify/>. Acesso em: 10 maio 2018. 
de um lugar violento e de gente desocupada, como retratado muitas vezes pelas autoridades, pela mídia e pelas redes sociais. A utilização dos meios de comunicação pela juventude periférica promove uma ressignificação ancestral em nossa sociedade, com uma conscientização da negritude de nosso país. Segundo Osumaré (2015, p. 25):

os hip-hoppers jovens herdaram o século xxı com sua independência e tecnologia como jamais aconteceu no passado. O tráfico da cultura negra tem existido desde o tráfico de escravos no Atlântico, mas agora a juventude de hoje promove, em ritmo acelerado, uma conscientização que continua a invocar as práticas culturais do passado da África negra, fazendo da diáspora um solo fértil para novas soluções de velhos problemas com a cultura hip-hop.

As fronteiras dissolvidas pelo processo de globalização e difusão tecnológica põem em questão velhas certezas e hierarquias de identidade, ainda que permeadas pelo excesso de consumo e mercantilização. Hall (2006) recorre ao conceito de "deslocamento" de Laclau (1990) para dizer que nossa sociedade está o tempo todo sendo movida por forças que deslocam o que está no centro para experimentar uma pluralidade de centros de poder. E o lado positivo desse deslocamento é que esse processo desarticula as identidades estáveis do passado, abrindo-se para novas possibilidades. A ampliação dos horizontes promove uma conexão mundial entre os negros, que se tornaram visíveis por meio da difusão dos meios de comunicação e da publicidade. A possibilidade de qualquer anônimo produzir conteúdos digitais, por exemplo, permite uma abertura mais democrática para a cultura da margem e da periferia para ocupar espaços que antes não eram possíveis. Conforme Arce (1999, p. 147):

As identidades sociais são complexos processos relacionais que se formam na interação social. Existem diferentes formas de identificação, cujos limites de adscrição são estabelecidos principalmente pela posição dos outros e não por uma definição grupal compartilhada que tende ganhar seus próprios espaços de reconhecimento. Desse modo, existem setores e grupos estigmatizados, para os quais a força do estigma muitas vezes acompanha a possibilidade de formar processos apropriados de identificação, apesar das respostas da sociedade global dominante.

Portanto, para que o desenvolvimento da população afro-brasileira seja, de fato, promovido dentro e fora do espaço escolar, precisamos 
reconhecer que essa sensação de game over tem de ser superada. Nossa sociedade experimenta uma nova configuração da violência, muito semelhante à que se apresentou no Bronx, em Nova York, há mais de trinta anos, e que, em uma dimensão maior, apenas manifesta um dilema mal resolvido que remete a uma América traumatizada por dores terríveis da colonização e do processo de escravatura.

\section{Conclusão}

Este estudo buscou apresentar um material teórico-empírico que pudesse trazer a dimensão educativa da cultura hip-hop, valorizando sua contribuição na formação da juventude afro-brasileira. Os relatos apresentados logo no início demonstram que o potencial dessa manifestação cultural é capaz de despertar no(a) aluno(a) o interesse pelo conhecimento oferecido pela escola pública no contexto da periferia.

Nos espaços de lazer, o hip-hop manifesta inúmeras possibilidades criativas de enfrentar a batalha vivenciada no ensino formal, na qual, muitas vezes, professores(as) e alunos(as) se sentem em uma guerra perdida. Assim como a rua, a escola também pode ser um ambiente divertido e, ao mesmo tempo, formativo. As diferentes expressões artísticas da cultura hip-hop conseguem promover um conhecimento que se articula com a linguagem e a realidade dos(as) jovens moradores(as) da favela e ainda permitem uma elaboração crítica da vida real. O enfrentamento, que muitas vezes é direcionado para a figura do(a) professor(a), pode deslocar-se para uma ação mais consciente, crítica e criativa em relação ao meio. Nesse sentido, o(a) aluno(a) precisa enxergar a escola como um espaço imaginário protegido, no qual ele(a) se sinta à vontade para transformar toda a sua rebeldia em potência criativa.

Para fazer da escola um espaço de desenvolvimento e diversão, é preciso reconhecer outros atributos e possibilidades que fogem da lógica escolar tradicional, abrindo-se para referências que não estão nos livros didáticos. Assim, é possível ampliar as possibilidades de identificação dos(as) alunos(as), permitindo que reconheçam habilidades e aptidões que vão muito além da escrita e da leitura, considerando também o corpo, o ritmo, a fala, o improviso e outros elementos fundamentais para o conhecimento. É como se o hip-hop representasse uma poderosa "arma" que dispara novos modelos de identificação e aprendizagem. Na mão do(a) professor(a), se essa "arma for bem manuseada", as mudanças vão surgindo paulatinamente: na sutileza de uma pergunta que expressa o 
despertar da curiosidade, no olhar atento que faz desaparecer o desinteresse pelas aulas e no comportamento dos(as) alunos(as), que aos poucos vão deixando de lado a postura reativa para assumir um posicionamento mais colaborativo e engajado.

Portanto, inspirados nesse processo de transformar a sala de aula em um ambiente educativo potente e prazeroso, concluímos esta reflexão com o depoimento de alguns participantes da pesquisa aqui apresentada.

No começo houve resistências, mas vários(as) alunos(as) que ficavam no canto hoje estão participando da produção das coreografias. Alunos(as) com dificuldade de aprendizagem, que tinham dificuldades para fazer a busca na internet, foram estudando os videoclipes e conseguiram construir um conhecimento sobre a cultura hip-hop. A evolução do processo é nítida em uma turma que tinha muita dificuldade de aprendizagem. Eles(as) estão tendo acesso aos elementos que são característicos da cultura negra, os movimentos de luta e de resistência, discutindo também diversidade, respeito, racismo, dentro de um trabalho rico e significativo para a formação desses(as) alunos(as), que pela prática e pela teoria tem enriquecido nosso repertório cultural.

(Professora Fernanda Moraes, educação física)

Com o rap, a gente percebe que o(a) aluno(a) cria, que o(a) aluno(a) tem o texto dentro dele(a), talvez ele(a) ainda não tenha amadurecido o suficiente para expressar da maneira formal, mas o processo de cada aula tem sido legal, porque mesmo o(a) aluno(a) mais difícil às vezes é o(a) aluno(a) que tem mais ritmo, tem mais facilidade, às vezes tem mais criatividade, então é bacana porque de alguma maneira atinge a autoestima desse(a) aluno(a), e com a autoestima um pouco mais valorizada esse(a) aluno(a) se sente um pouco mais à vontade para de repente conquistar outras coisas na escola também.

(Professor Sidnei Gomes Leal, história)

Após participar desse projeto, eu mudei quase que totalmente o meu conceito sobre as nossas origens, sobre a cultura e o passado afro-brasileiro. No começo eu não me importava muito com o projeto, pois não me parecia interessante. Isso mudou depois de 
algumas aulas, pois vi que o projeto era muito legal e importante. Agora eu mudei de escola e pensei em dar continuidade ao projeto aqui, desenvolvendo algo parecido para que mais pessoas conheçam nossa cultura do passado. Agradeço a Elaine e a sua equipe, que sempre estavam dispostos a nos ensinar. Agradeço a cada palavra dita por eles, por cada lição de vida que levaremos para sempre, algo que ninguém pode pegar da gente, agradeço a cada saída educativa, que com o pessoal do projeto se tornava algo divertido, envolvente e descontraído. Aprendi muito com isso, nunca mais vou esquecer vocês.

(Aluno Felipe Santos Teodolino, 14 anos)

\section{Referências}

8 Mile - Rua das ilusões. Direção: Curtis Hanson. Roteiro: Scott Silver. Elenco: Eminem, Kim Basinger, Brittany Murphy, Mekhi Phifer, Anthony Mackie. Califórnia: Universal Pictures, 2002.

Amaral, M. G. T.; Reis, R.; Santos, E. C. M.; Dias, C. C. (Org.). Culturas ancestrais e contemporâneas na escola: novas estratégias didáticas para a implementação da lei 10.639/03. São Paulo: Editora Alameda, 2018. (no prelo).

Amaral, M. G. T.; Dias, C. C.; Tejera, D. B. O. Do cinema de vanguarda ao videoclipe dos Racionais MC’s: uma discussão a partir de Vilém Flusser, Walter Benjamin e T. W Adorno. Revista Tempos e Espaços em Educação, São Cristóvão, Sergipe, v. 11, n. 24, p. 111-126, jan./mar. 2018. Disponível em: <http://dx.doi.org/10.20952/revtee.v11i24.7643>. Acesso em: 3 maio 2018.

Arce, J. M. V. Vida de barro duro: cultura popular juvenil e grafite. Rio de Janeiro: Editora UFRJ, 1999.

Asante, M. K. Afrocentricity: the theory of social change. Buffalo: Amulefi Publishing Company, 1980.

Bakhtin, M. A cultura popular na Idade Média e no Renascimento: o contexto de François Rabelais. Trad. de Yara Frateschi Vieira. São Paulo: Hucitec; Brasília, DF: Editora Universidade de Brasília, 2008. p. 4.

Benjamin, W. A doutrina das semelhanças. In: Benjamin, W. Magia e técnica, arte e política. São Paulo: Editora Brasiliense, 1996. (Obras escolhidas, v. 1).

Bourdieu, P. O poder simbólico. Rio de Janeiro: Bertrand Brasil, 2001. 
Brasil. Lei n. 9.394, de 20 de dezembro de 1996. Estabelece as Diretrizes e Bases da Educação Nacional. Diário Oficial da União, Brasília, DF, 23 dez. 1996.

Brasil. Lei n. 10.639, de 9 de janeiro de 2003. Altera a lei n. 9.394, de 20 de dezembro de 1996, que estabelece as diretrizes e bases da educação nacional, para incluir no currículo oficial da Rede de Ensino a obrigatoriedade da temática "História e Cultura Afro-Brasileira", e dá outras providências. Diário oficial da União, Brasília, DF, 10 jan. 2003.

BRASIL. Diretrizes Curriculares Nacionais para a Educação das Relações Étnico-Raciais e para o Ensino de História e Cultura Afro-Brasileira e Africana. Brasília, DF: Ministério da Educação, 2004.

Chaui, M. A universidade pública sob nova perspectiva. Revista Brasileira de Educação, Rio de Janeiro, n. 24, p. 5-15, 2003.

Chaui, M. As manifestações de junho de 2013 em São Paulo. Teoria e Debate, São Paulo, ed. 113, 2013. Disponível em: <https://teoriaedebate.org. br/2013/06/27/\%ef\%bb\%bfas-manifestacoes-de-junho-de-2013-na-cidadede-sao-paulo/>. Acesso em: 4 maio 2018.

Diaz, M. Renegados: os empreendedores sociais do hip-hop liderando o caminho para a mudança social. In: Amaral, M.; CARriL, L. O hip-hop e as diásporas africanas na modernidade: uma discussão contemporânea sobre cultura e educação. São Paulo: Alameda, 2015. p. 165-188.

Dumazedier, J. Vers une civilization du loisir? Paris: Editions du Seuil, 1972. Elias, N.; Dunning, E. A busca da excitação. Lisboa: Difusão Editorial, 1985.

Freud, S. O mal-estar na civilização. In: Sigmund Freud. Obra completa. Rio de Janeiro: Imago, 1996 (Edição Standard das obras psicológicas completas de Sigmund Freud, v. XXI).

Gagnebin, J. M. O conceito de mímesis no pensamento de Adorno e Benjamin. São Paulo: Perspectivas, 1993.

Hall, S. A identidade cultural na pós-modernidade. 11. ed. Rio de Janeiro: DP\&A, 2006.

Hill, M. L. Batidas, rimas e vida escolar: pedagogia hip-hop e as políticas de identidade. Rio de Janeiro: Editora Vozes, 2014.

Kohn, N. M.; Silva, M. L.; Abud, C. C. (Org.). O racismo e o negro no Brasil: questões para a psicanálise. São Paulo: Perspectiva, 2017.

LAClaU, E. New reflections on the revolution of our time. London: Verso, 1990. 
Marcellino, N. C. Estudos do lazer: uma introdução. 3. ed. Campinas: Autores Associados, 2002.

Matos, O. A narrativa: metáfora e liberdade. Revista História Oral, Rio de Janeiro, v. 4, p. 9-24, 2001. (Dossiê Narrativas e narradores).

Mclaren, P. Multiculturalismo crítico. São Paulo: Cortez, 1997.

Meirelles, R.; Athayde, C. Um país chamado favela: a maior pesquisa já feita sobre a favela brasileira. São Paulo: Editora Gente, 2014.

Osumaré, H. Marginalidades conectivas do hip-hop e a diáspora africana: os casos de Cuba e do Brasil. In: Amaral M.; CarriL, L. (Org.). O hip-hop e as diásporas africanas na modernidade: uma discussão contemporânea sobre cultura e educação. São Paulo: Alameda, 2015. p. 63-92.

Sabotage. Um bom lugar. Intérprete: Sabotage. In: SAbotage. Rap é compromisso. São Paulo: Cosa Nostra Fonográfica, 2000. 1 CD. Faixa 3 (5:38 min.).

Silva, J. C. G. Arte e educação: a experiência do movimento hip-hop paulistano. In: Andrade, E. N. A. (Org.). Rap e educação, rap é educação. São Paulo: Summus, 1999. p. 23-38.

SoDré, M. A verdade seduzida. 3. ed. Rio de Janeiro: DP\&A, 2005.

WLRA - World Leisure and Recreation Association. Carta Internacional de Educação para o Lazer. In: SEMINÁRIO INTERNACIONAL DE EDUCAÇÃo PARA O LAZER. Jerusalém: WLRA, 1993. Disponível em: <http://www.saudeemmovimento.com.br/conteudos/conteudo_exibe1.asp?cod_noticia=195>. Acesso em: 14 abr. 2018. 


\title{
CAPÍTULO 6
}

\section{PROJETOS SOCIAIS E DANÇA: LAZER, EDUCAÇÃO E MEDIAC̣ÃO CULTURAL}

\author{
Elisângela Chaves \\ Gustavo Pereira Côrtes \\ Juliana Araújo de Paula
}

Ao sermos convidados para a escrita deste texto, nos vimos desafiados a uma profunda reflexão sobre as continuidades e mudanças pelas quais a dança vem sendo impactada na contemporaneidade. A dança é uma forma de expressão complexa que se comunica envolvendo valores, aspirações e insatisfações, crenças e linguagens, como uma manifestação legítima da produção humana. Dessa forma, a dança traduz um fenômeno social que abrange elementos importantes como a diversidade e o pluralismo cultural. "A compreensão de como movimentos dançados contam histórias, apresentam problemas ancestrais, míticos ou mesmo de origem urbana contemporânea, implica dominar o código cultural no qual ela se insere" (Siqueira, 2006, p. 72). Perante a diversidade de movimentos produzidos e reproduzidos ao longo da história da humanidade, indivíduos e grupos atribuem sentidos e significados múltiplos para a vivência e expressão da dança na vida social, incluindo aí as práticas de lazer, de educação e de produção artística.

Neste texto, focados em reflexões acerca da educação para o lazer, nos debruçaremos sobre os desafios do ensino da dança em um território em expansão, de poucas diretrizes e muitas variações: os projetos sociais. Estamos elegendo neste ensaio como projetos sociais as iniciativas vinculadas aos governos e/ou a organizações da sociedade civil, que de diferentes formas, intencionalidades e objetivos têm nas práticas esportivas e/ ou artísticas suas principais ferramentas de intervenção social. Diversas 
experiências apresentam, nesse sentido, pontos em comum, como cita Victor Melo (2008, p. 2):

a) apresentam-se como alternativas de promoção de inclusão social, tendo em vista o quadro de desigualdade que grassa em nosso país;

b) com isso, adotam o discurso de vinculação com a ideia de construção de cidadania, ainda que muitas vezes tratem do conceito de forma genérica e imprecisa;

c) normalmente são iniciativas organizadas para ocupação do tempo livre dos frequentadores, ainda que alguns tenham algum grau de relacionamento com a escola (por exemplo, oferecendo também reforço escolar/explicadores, ou exigindo a frequência nas salas de aula, alguns até mesmo certo grau de desempenho, para a manutenção da participação dos envolvidos nas atividades);

d) majoritariamente contam com a participação de organizações não governamentais (ONGs), seja como líderes exclusivas do projeto (responsável pela estruturação e operacionalização, a partir de financiamento de fontes privadas diversas, como as advindas de fundações internacionais ou nacionais), seja conduzindo o projeto fazendo uso de recursos públicos distribuídos em editais (como os lançados pela atual gestão do governo federal no âmbito dos ministérios do Esporte e da Cultura) ou mesmo sendo convocadas pelo próprio poder público para em seu nome desempenhar determinadas ações.

Entre as diversas linguagens artísticas compreendidas enquanto atividades de lazer, a dança está intensamente presente em projetos sociais, com diferentes abordagens que se desenvolvem nos espaços escolares e comunitários em parcerias várias com governos, organizações não governamentais (ONGs), entidades filantrópicas e de inciativa privada mediante editais e recursos públicos. Tal fato redimensiona as reflexões sobre o ensino da dança no Brasil e nos provoca a estar constantemente atentos à necessidade de reflexões teóricas e práticas acerca das intervenções e abordagens metodológicas construídas nesses contextos. Importante destacarmos que a proposta de um projeto social organizado em comunidades pobres, ou oferecido à população em situação 
de vulnerabilidade, por si só não garante que ele seja "social", e muito menos de qualidade, inclusivo e crítico. $\mathrm{O}$ acesso da população a essas práticas na perspectiva de suas experiências locais possibilita a realização de uma mediação cultural, estabelecendo diálogos teóricos entre experiências desenvolvidas nos projetos e aspectos simbólicos representativos das relações culturais, entre o singular e o coletivo. Bernard Lamizet (1998) aponta uma definição ampla que sinaliza a importância da mediação cultural nos processos de representação do indivíduo na sociedade:

A mediação representa o imperativo social essencial da dialética entre o singular e o coletivo, e da sua representação em formas simbólicas. A sociedade pode existir apenas se cada um dos seus membros tem consciência de uma relação dialética necessária entre a sua própria existência e a existência da comunidade: é o sentido da mediação que constitui as formas culturais de pertença e de sociabilidade dando-lhes uma linguagem e dando-lhes as formas e os usos pelos quais os atores da sociabilidade apropriam-se dos objetos constitutivos da cultura que funda simbolicamente as estruturas políticas e institucionais do contrato social [LAMIZET, 1998, p. 9].

De acordo com o conceito proposto pelo autor, pensar a mediação cultural lançando mão de trabalhos com a dança em projetos sociais implica redimensionar matrizes de significação na cultura vinculadas à ludicidade, à tradição, à atividade física, à arte e à educação como desenvolvimento individual e transformação social.

Os projetos sociais têm marcado a expansão de espaços para o ensino da dança de forma contundente no Brasil, o que outrora se limitava a escolas, academias, clubes e associações filantrópicas. Nas relações da vida cotidiana e na organização e planejamento de cada projeto há um pluralismo de métodos, estilos, técnicas e intencionalidades. Entretanto, a maioria das experiências traz em comum a perspectiva de que a dança organizada e praticada em tais projetos é potencialmente transformadora de realidades várias, gerando ações e reflexões na convivência coletiva, nas mais diversas trocas de experiências no lazer em práticas sociais. Muitas ações desenvolvidas em projetos sociais têm gerado reflexões a respeito da prática e das potências teóricas na construção de novos conhecimentos que buscam qualificar o acesso da população às práticas de lazer, com diálogos apoiados em suas experiências locais para uma nova 
compreensão simbólica das relações sociais. Refletir acerca desse aspecto amplia o olhar dos estudos para uma relação dialética existente entre as ações sociais desenvolvidas por projetos institucionalmente constituídos em escolas e os estudos sobre o lazer. Essa expansão no ensino da dança trouxe o aumento de locais de prática, número de alunos e diversidade nas produções artísticas em dança, especialmente relacionadas aos mais diversos estilos. Mas o que isso reverbera na formação dos indivíduos praticantes na educação para e pelo lazer?

\section{Reflexões sobre a dança, a educação e a mediação cultural}

O ensino da dança inserido na educação formal vem historicamente enfrentando desafios, resistências e rejeições da organização curricular escolar no Brasil. Seja como subárea das artes ou como conteúdo da educação física, a dança na escola constitui-se de forma precária, compondo mais uma manifestação coreográfica em datas comemorativas do que propriamente uma área de conhecimento estabelecida nos currículos de formação do ensino infantil, fundamental e médio. Por mais produção de conhecimento que se acumule sobre seus benefícios e possibilidades educativas, as limitações na formação de professores, os preconceitos que envolvem o tema e as disputas na esfera formal escolar ainda não permitiram que o ensino da dança fosse compreendido para além da visão simplista de utilidade performática. $\mathrm{O}$ ensino institucional da dança é pulverizado entre a distribuição de carga horária, conflitos de área e a continuidade de métodos tradicionais na supervalorização da formação intelectualizada em detrimento de uma formação integral, reflexiva e crítica.

Na busca da superação de dificuldades educacionais, principalmente para a população em situação de vulnerabilidade, alternativas no campo da educação não formal têm sido um campo fértil de experimentações de propostas outras que atendam a diferentes objetivos, considerando aí a complementação da formação, a retirada dos jovens das ruas, além de ações filantrópicas, educação profissionalizante e práticas de lazer.

No contexto atual da educação pública, o que se percebe é a franca expansão de propostas que visam a uma formação mais diversificada aliada à ampliação da jornada escolar. Em grande parte, isso se deve à criação do Programa Mais Educação pelo Ministério da Educação (MEC), em 2007. Especialmente a partir de 2015, o programa passou 
a ser chamado de "Novo Mais Educação" e, de acordo com Mendonça (2017, p. 169), “deixa de ser uma política indutora de Educação Integral e passa a ser uma política de extensão de jornada para a melhoria da aprendizagem dos conteúdos escolares de português e matemática". Trata-se de uma estratégia indutora para a implantação de uma política de educação integral no país que conta com o suporte técnico e financeiro dos sistemas de ensino municipais e estaduais para ampliar a jornada escolar. Apesar da mudança de foco do governo atual em relação ao programa original, ainda é possível reconhecer a permanência de ações e práticas voltadas para a ampliação das oportunidades de aprendizagem, para além da matemática e do português. Esse programa trouxe como concepção de educação integral o entendimento de que os processos educativos devem ser potencializados não apenas no interior da escola, mas também em outros espaços. Além disso, opera com a lógica da ampliação de tempos de aprendizagem aliada a uma formação do sujeito igualmente ampliada.

Essa perspectiva, no entanto, não é um consenso. "Alguns educadores adeptos da escola de tempo integral defendem a ideia de que mais tempo para desenvolver a matriz curricular é a principal razão de ampliação do tempo escolar" (LEITE et al., 2015, p. 37). A ampliação do tempo de permanência na escola atende a uma demanda muito específica de afastamento das crianças de situações de risco e vulnerabilidade: estar na escola significa estar protegido da violência social. Esse, no entanto, é apenas um aspecto de uma discussão que é muito mais ampliada, cujo tema da educação integral situa-se constantemente em espaços de disputa ideológica. Assim, o debate acadêmico sobre a educação integral tem sinalizado preocupação com a qualidade da utilização do tempo que é oferecido às crianças e jovens nas atividades, para além do que é oferecido pela educação formal. Arroyo (2012, p. 33) levanta uma importante questão: "uma forma de perder seu significado político será limitar-nos a oferecer mais tempo da mesma escola, ou mais um turno - turno extra - ou mais educação do mesmo tipo de educação". Nessa mesma linha, Cavaliere (2007, p. 1.021) defende que "a ampliação do tempo de escola somente se justifica na perspectiva de propiciar mudanças no caráter da experiência escolar, ou melhor, na perspectiva de aprofundar e dar maior consequência a determinados traços da vida escolar".

A educação integral, nessa perspectiva, tem a possibilidade de impulsionar e ressaltar aprendizagens historicamente relegadas a segundo 
plano ou, quando muito, valorizadas quando associadas àquelas já tradicionalmente reconhecidas. Nesse sentido, a dança, mesmo estando presente nos componentes curriculares Arte e Educação Física na nova proposta da Base Nacional Comum Curricular (BNCC) de 2018, ganha maior expressividade e legitimidade no processo de formação dos estudantes nas ações desenvolvidas nas propostas da educação integral. $\mathrm{O}$ mapeamento e a análise de diversas experiências de educação integral do Brasil, realizados pelo estudo Educação integral/educação integrada e(m) tempo integral: concepções e práticas na educação brasileira (BRASIL, 2009) ${ }^{1}$, apontaram a expressiva presença de oficinas de danças em escolas com jornadas ampliadas.

Em nível nacional, observamos, ainda, que 65\% das experiências identificadas pela pesquisa apresentam o esporte como uma atividade privilegiada na jornada ampliada. Na sequência, constatamos o desenvolvimento de aulas de reforço - implementadas por $61,7 \%$ das experiências; a música $(57,1 \%)$ e a dança $(54 \%)$, seguidas pelo teatro $(46,4 \%)$, pela informática $(45,6 \%)$ e pelas oficinas temáticas $(44,9 \%)$, afora o artesanato $(40,5 \%)$ e as tarefas de casa $(40,2 \%)$, entre outras [BRASIL, 2009, p. 25-26].

No contexto de Belo Horizonte, identificamos com grande projeção social a educação integral que se efetiva nos programas Escola Integrada (PEI) e Escola Aberta (PEA). Assim como no contexto nacional, a dança tem forte presença nesses programas, o que abre possibilidades para reflexões sobre a forma como é desenvolvida a construção de cidadania nesses espaços e qual o discurso adotado para esse fim, bem como observar o aproveitamento da ocupação do tempo livre dos frequentadores com uso de recursos públicos para realizar determinadas ações.

1 Essa pesquisa foi realizada por um grupo de universidades públicas federais a pedido do MEC. Realizada em duas etapas, quantitativa e qualitativa, apresentou como objetivos: "mapear experiências de ampliação de jornada no ensino fundamental em curso no Brasil; analisar as experiências mapeadas a partir da construção de critérios que evidenciassem suas concepções e práticas; e, ainda, subsidiar a proposição de políticas públicas voltadas para a implementação de educação integral, em nível nacional” (BRASIL, 2009, p. 6). 


\section{A dança nos programas Educação Integral e Escola Aberta em Belo Horizonte}

Os programas PEI e $\mathrm{PEA}^{2}$ compõem a política de educação integral da rede municipal de Belo Horizonte. $\mathrm{O}$ funcionamento do PEI no cotidiano da escola ocorre conforme a oferta, no contraturno escolar, de oficinas e aulas-passeio. O PEA, por sua vez, é realizado nos finais de semana e atende, além dos estudantes, toda a comunidade escolar. Atualmente, o PEI conta com um total de 170 oficinas de dança em 129 das 173 escolas que desenvolvem o programa. Isso representa $74 \%$ de escolas oferecendo oficinas de dança. No PEA são realizadas 174 oficinas de dança em 100 escolas das 171 contempladas com o programa ${ }^{3}$. É possível afirmar que nesses programas coexiste uma diversidade de estilos de danças trabalhados nas oficinas. Em ambos, entretanto, destaca-se a presença das oficinas de dança contemporânea e dança de rua, conforme descrito nos Gráficos 1 e $2^{4}$.

Gráfico 1 - Distribuição dos estilos de dança no Programa Escola Integrada

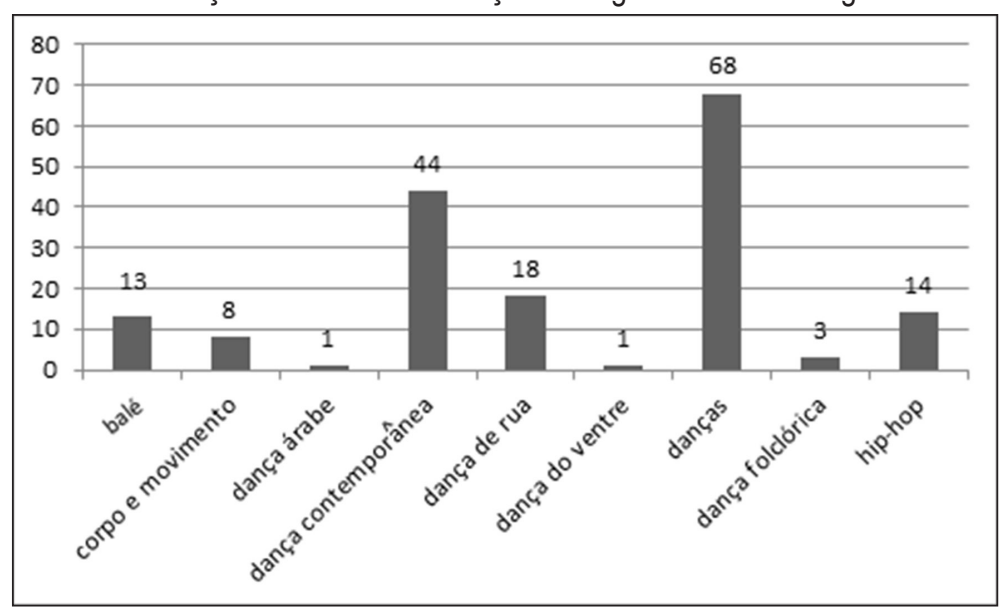

Fonte: Sistema de Gestão do Programa Escola Integrada - SMED.

2 O Programa Escola nas Férias, realizado nos períodos de férias escolares, também compõe essa política.

3 Dados referentes ao mês de fevereiro de 2018, disponibilizados pela Secretaria Municipal de Educação (SMED) conforme seu sistema de gestão.

4 A nomeação das oficinas é o que nos auxilia a identificar o estilo de dança trabalhada, e é uma atribuição das escolas. No Programa Escola Integrada, identificamos 68 denominações de "danças", sem identificação do estilo, o que nos sugere que as oficinas denominadas como "danças" referem-se às práticas não vinculadas a um estilo específico, ou com variação de estilos, sem determinação precisa. 
Gráfico 2 - Distribuição dos estilos de dança no Programa Escola Aberta

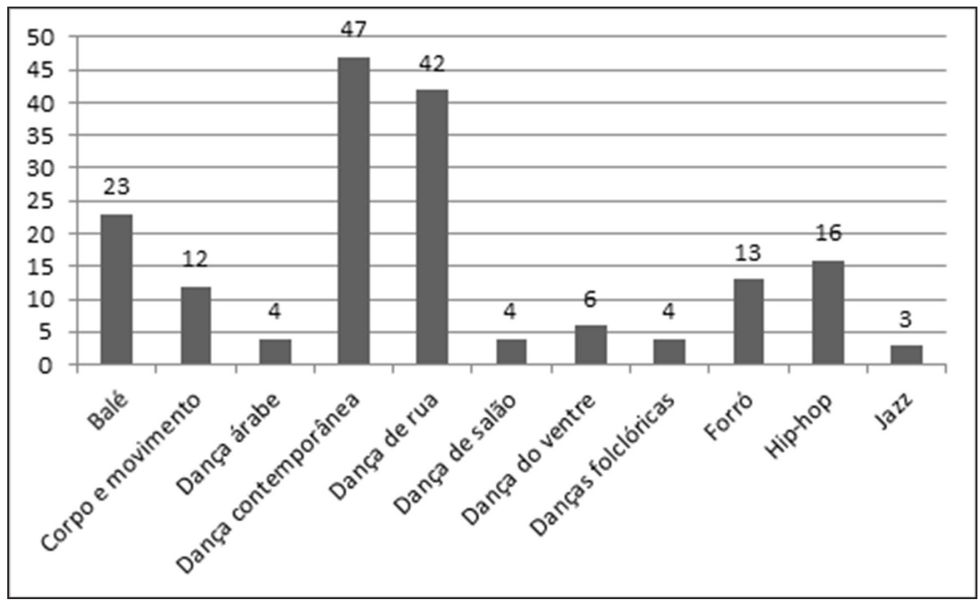

Fonte: Sistema de Gestão do Programa Escola Aberta - SMED.

A dança, nesse contexto, tem presença marcada não somente nos momentos de oficina no cotidiano de realização dos programas. Como afirma Paula (2017, p. 19):

São possibilitadas diferentes oportunidades de apresentações em diferentes situações, como festivais, seminários e eventos culturais da cidade. Dessa maneira, o estudante que participa da dança tem a chance de vivenciar contextos que fazem parte dessa prática e que, por isso, são também contextos de aprendizagem.

Além de vivenciarem a experiência de subir ao palco e apresentar trabalhos artísticos, os participantes desses programas também ocupam o lugar de plateia e de apreciadores da arte. O PEI e o PEA têm como diretriz a articulação de diversos setores da sociedade, de forma que participam e colaboram para o processo de formação dos envolvidos. "Essas ações oportunizam aprendizagens nas áreas pedagógica, cultural, esportiva, artística, de lazer e formação cidadã, ofertando atividades nos diferentes lugares e espaços para além dos muros da escola, além das viagens pedagógicas dentro e fora de Belo Horizonte" (Belo Horizonte, 2015, p. 24).

O contorno desses programas educativos e a maneira como a formação é pensada de forma ampliada abrem possibilidades para uma análise teórica no campo de estudos do lazer. Para além dos processos 
evidentemente educativos e aliados a uma lógica escolar, como o que acontece nas oficinas, nos referidos programas a formação dos sujeitos ultrapassa os muros e as perspectivas estritamente escolares. Nesse contexto, "a presença de saberes, até então fora da cultura escolar, trouxe para dentro da escola novos educadores - agentes culturais, oficineiros, monitores; em sua maioria jovens que participam de movimentos e ações nas suas comunidades, em especial aqueles ligados às vivências culturais" (LeITE et al., 2015, p. 46). Há, com isso, maior possibilidade de compreender-se a aprendizagem da dança com um olhar ampliado para as aprendizagens que ocorrem na escola, tendo em vista que estas dialogam diretamente com aquelas que também ocorrem fora dela, em um processo de mediação cultural.

\section{Dança e projetos sociais: educação para e pelo lazer}

Ao analisarmos os dados e as experiências das ações do PEA e da educação integrada, refletimos que as relações entre dança, cultura e lazer são indissociáveis nessas perspectivas de mediação de saberes, vivências e produções. Ao trazermos as experiências desses programas desenvolvidos em Belo Horizonte, partimos para uma reflexão sobre a sua importância para uma educação "para e pelo lazer". O acesso ao lazer e ao esporte é um direito social dos brasileiros, estipulado na lei fundamental e suprema de nosso país, a Constituição Federal, promulgada em 1988. Compreender o lazer também como possibilidade de uma experiência estética, que não se confunde com o que é proposto apenas pela indústria do entretenimento, é mais um desafio para a formação de profissionais que trabalham nesses programas. Baseados nas reflexões de cada experiência, visualizamos como essas propostas e ações fundadas e referenciadas no campo da educação dialogam e constituem processos de mediação cultural para as experiências de lazer.

Na relação entre programas educacionais e estudos sobre o lazer, a mediação cultural pode ser analisada por conceitos forjados na linguística, como uma atividade de produção de sentido, por meio da língua, no entorno das experiências compartilhadas das obras de arte (LAMIZET, 1998). Segundo Costa (2009, p. 1), há uma "profusão/confusão de termos para distinguir as atividades profissionais na área cultural que ocorre tanto na França quanto no Brasil. Termos como 'mediação cultural' tentam organizar um campo de trabalho, mas para isso precisam dialogar 
com outras nomenclaturas como a animação sociocultural”. A animação cultural inclui a mediação em sua definição, e as diferenciações entre ambas parecem mais terminológicas que conceituais em relação ao cerne do debate. Para Melo (2006, p. 28-29):

Animação Cultural como uma tecnologia educacional (uma proposta de intervenção pedagógica), pautada na ideia radical de mediação (que nunca deve significar imposição), que busca contribuir para permitir compreensões mais aprofundadas acerca dos sentidos e significados culturais (considerando as tensões que nesse âmbito se estabelecem) que concedem concretude a nossa existência cotidiana, construída a partir do princípio de estímulo às organizações comunitárias (que pressupõe a ideia de indivíduos fortes para que tenhamos realmente uma construção democrática), sempre tendo em vista provocar questionamentos acerca da ordem social estabelecida e contribuir para a superação do status quo e para a construção de uma sociedade mais justa.

Animar ou mediar parecem definições muito próximas e pertinentes para fundamentar nossas reflexões sobre a potencialidade dos projetos e programas sociais que elencam a dança como uma prática capaz de promover transformações nos modus vivendi de indivíduos e comunidades nas mais diferentes faixas etárias e condições de vida. Podemos ainda problematizar questões como apresentaram Galvão Souza, Pereira e Melo (2006, p. 146), ao indagarem se "os projetos sociais" de dança estão preocupados em educar a sensibilidade de seu público-alvo para o consumo ativo e crítico dos espetáculos coreográficos. Refletindo sobre a questão, acreditamos que as ações desenvolvidas nos projetos possibilitam tornar os indivíduos produtores de cultura, não só quando promovem a consciência de que podem dançar de formas diferenciadas, mas também ao despertá-los para a possibilidade de dialogar criticamente com a apreciação artística baseados em sua experiência corporal com a dança.

Nesse sentido, existe uma perspectiva ampliada de educação e cultura considerando o ato de dançar como expressão e comunicação humana na construção social do indivíduo. Conforme Siqueira (2006, p. 73), "A dança é um texto cultural que reflete as condições, elementos e experiências culturais, tecnológicos e temáticos da sociedade. É uma forma de comunicação, uma linguagem que contém elementos universais e particulares ou específicos de uma dada cultura”. 
É nessa conexão cultural que dança, educação e lazer nos possibilitam a percepção de conflitos, tensões, contradições e complexidades. De manifestações tradicionais a inovações, do conformismo à resistência, encontramos na ambiguidade dos corpos dançantes a possibilidade da interpretação crítica da ordem social por intermédio da dança, da arte e do lazer. Como nos explicita Gomes (2014, p. 15),

o lazer como necessidade humana e dimensão da cultura que se constitui na articulação de três elementos fundamentais: a ludicidade, as manifestações culturais e o tempo/espaço social. Tal necessidade pode ser satisfeita de múltiplas formas, segundo os valores e interesses dos sujeitos, grupos e instituições em cada contexto histórico, social e cultural. Nessa linha de interpretação, o lazer é uma prática social complexa que abarca uma multiplicidade de vivências culturais lúdicas contextualizadas e historicamente situadas.

Ludicidades e representações por intermédio da arte, da educação e do lazer envolvem diferenças étnicas, de gênero, raça, classe social e econômica. O reconhecimento da pluralidade e da diversidade cultural, também para dança, é um tema relevante para as propostas políticas e educacionais que combatam as discriminações e exclusões, em um processo de aceitação e tolerância das diferenças para fortalecer e perpetuar os direitos sociais, as políticas públicas, as identidades culturais e as liberdades de expressão. Uma educação que englobe o respeito e a acessibilidade à diversidade cultural deve ser entendida como premissa de orientação para a mediação cultural.

Destacamos o estudo realizado em Belo Horizonte, no qual Ribeiro (2018, p. 123), ao analisar o Projeto Anjos da Rua5, reforça que "A articulação entre arte, cultura e educação mostrou-se, na experiência analisada, não só um caminho possível, mas, ainda, integração entre educador e educandos, na construção do conhecimento em ação e sua significativa construção no coletivo". Tal discussão corrobora nossa reflexão de que

5 O Projeto Anjos da Rua se denomina como uma ação social de educação não escolarizada que atende crianças e jovens com aulas de dança, dedicado à formação de bailarinos, principalmente em danças urbanas, com práticas da cultura hip-hop. Concebido em 2002, desde de 2012 foi integrado ao PEA na cidade de Belo Horizonte. Em quinze anos de projeto, foram atendidas mil pessoas, e atualmente conta com aproximadamente 530 alunos. O projeto tem uma trajetória de participação e vitórias em competições pelo Brasil (RIBEIRO, 2018). 
o indivíduo tem a possibilidade de conhecer e valorizar a pluralidade de expressões artísticas em projetos sociais ao usufruir dos equipamentos e dos espaços disponíveis para as práticas educacionais e lúdicas. A perspectiva de compreender a cidadania como participação social e política, no exercício de direitos e deveres sociais, civis e políticos, revela a amplitude de significados que os projetos adquirem com a ampliação de atividades com dança. Os temas trabalhados nas coreografias, em sua diversidade de concepções e particularidades, comunicam ideários contemporâneos e refletem uma sociedade em processo de mudança com situações diversificadas, que deixam a narrativa em aberto no diálogo entre o dançarino e o público, tornando a dança um espaço de interação entre o indivíduo e a sociedade.

Entendemos, enquanto sujeitos construtores da história de nosso tempo, que essas propostas podem atuar criticamente contra os modelos e as práticas discriminatórias em relação à classe social, raça, religião, gênero, idade, territorialidade etc. A efetivação da presença contundente da dança nos projetos e programas em Belo Horizonte nos possibilita refletir acerca da pluralidade de expressões, técnicas, estilos e significados que o ato de dançar oferece como fenômeno social. Melo (2006) destaca que tais propostas ajudam na valorização da arte como produção cultural na sociedade, na construção de diálogos entre os diferentes grupos sociais.

A arte cumpre sua função social quando permite ao indivíduo exercer sua possibilidade de crítica e de escolha; quando amplia, ao incomodar, as formas de ver a realidade; quando educa para a necessidade de olhar cuidadosamente (tão importante em um mundo de signos e símbolos); também quando desencadeia vivências prazerosas (embora estas não devam ser consideradas como único padrão de julgamento: por vezes não é essa a intencionalidade do artista). Quando cumpre esses papéis, a arte extravasa sua existência para além da manifestação em si. Quando não, as obras podem não passar de algo amorfo para alguns, privilégio de uma minoria [MeLo, 2006, p. 36-37].

Importante destacar que ao se organizarem propostas sociais é fundamental que as questões anteriormente citadas sejam abordadas com base na necessidade da própria comunidade, cujo papel não pode ser entendido como parte passiva na organização e no planejamento das ações. Durante todo o processo é fundamental o diagnóstico da comunidade e 
a fala dos atores. As propostas com o olhar de "fora" precisam do confronto com os olhares "de dentro" das comunidades. Desde a criação, implementação e avaliação dos programas e projetos, as ações precisam ser mediadas entre os agentes que compõem a cena durante todo o processo de execução do trabalho. Fazer parte de todo o planejamento gera o sentimento de pertencimento, de identidade que ocupa espaço na vida, na memória, nas orientações e nas escolhas no tempo presente e futuro. Assim, os responsáveis pelo ensino da dança nas propostas educacionais devem mediar as relações entre todos os atores, auxiliando na construção da linguagem artística do intérprete e criando possibilidades do fazer coletivo na formação do grupo. Entre os benefícios proporcionados pela prática de danças nas atividades de lazer em projetos existentes nas comunidades, existe um grande potencial social, que une as pessoas e promove a valorização da arte e da cultura.

A relação da dança com a educação tem recebido investimentos em pesquisas como conhecimento das artes e da educação física, especialmente. Como estudo no campo do lazer, os debates envolvendo o assunto ainda são incipientes. Para concluir, reforçamos a necessidade de serem promovidas reflexões críticas acerca da temática, pois existe uma clara expansão do ensino da dança nos projetos sociais em todo o país. A lente reflexiva das experiências em Belo Horizonte, na pluralidade e na diversidade de ações desenvolvidas nos programas sociais da cidade, revelam possibilidades crescentes dos estudos da presença da dança em projetos sociais, em que a mediação cultural pode ser refletida na ação transformadora de uma educação para e pelo lazer.

\section{Referências}

Arroyo, M. G. O direito a tempos-espaços de um justo e digno viver. In: Moll, J. (Org.). Caminhos da educação integral no Brasil: direito a outros tempos e espaços educativos. 1. ed. Porto Alegre: Penso, 2012. p. 33-45.

Belo Horizonte. Secretaria Municipal de Educação. Gerência de Educação Integral, Direitos Humanos e Cidadania. Educação integral: diretrizes político-pedagógicas e operacionais. Belo Horizonte, 2015.

BRAsIL. Ministério da Educação. Educação integral/educação integrada e $(m)$ tempo integral: concepções e práticas na educação brasileira. Mapeamento das experiências de jornada escolar ampliada no Brasil. Brasília, DF, 2009. Disponível em: <http://www.ufmg.br/online/>. Acesso em: 4 jan. 2016. 
Brasil. Programa Mais Educação: passo a passo. Brasília, DF, 2011. Disponível em: <http://portal.mec.gov.br/dmdocuments/passoapasso_maiseducacao.pdf $>$. Acesso em: 27 jun. 2015.

Cavaliere, A. M. V. Tempo de escola e qualidade na educação pública. Educação \& Sociedade, Campinas, v. 28, n. 100 Especial, p. 1.015-1.035, out. 2007. Disponível em: <http://www.cedes.unicamp.br>. Acesso em: 12 maio 2018.

Costa, L. F. Um estudo de caso sobre a mediação cultural. In: EnEcult Encontro de Estudos Multidisciplinares em Cultura, 5., 2009, Salvador. Anais... Salvador: UFBA, 2009. p.1-12.

Galvão Souza, M. I. ; Pereira, P. G.; Melo, V. A. Dança e animação cultural: "improvisações". Pensar a Prática, Goiânia, v. 6, p. 139-156, nov. 2006. Disponível em: <https://www.revistas.ufg.br/fef/article/view/60>. Acesso em: 3 maio 2018.

Gomes, C. L. Lazer: necessidade humana e dimensão da cultura. Revista Brasileira de Estudos do Lazer, Belo Horizonte, v. 1, n. 1, p. 3-20, 2014.

LAmizet, B. La médiation culturelle. Paris: L'Harmattan, 1998.

LEITE, L. H. A. et al. A educação integral como direito: concepções e desafios. In: Guimarães, M. B. et al. Educação integral: contribuições da extensão da UFMG. Belo Horizonte: Editora UFMG, 2015. p. 33-52.

Melo, V. A. A animação cultural: conceitos e propostas. Campinas: Papirus, 2006. p. 144.

Melo, V. A. "Projetos sociais" de esporte e lazer: reflexões, inquietações, sugestões. Quaderns d'Animació i Educació Social, Valencia, España, n. 7, enero 2008. Disponível em: <http:quadernsanimacio.net>. Acesso em: 3 maio 2018.

Mendonça, P. M. O direito à educação em questão: as tensões e disputas no interior do Programa Mais Educação. 2017. 179f. Tese (Doutorado em Educação) - Faculdade de Educação, Universidade Federal de Minas Gerais, Belo Horizonte, 2017.

PAula, J. A. "Isso dá para aprender!": a dança na educação integral. 2017. 89f. Dissertação (Mestrado em Educação) - Faculdade de Educação, Universidade Federal de Minas Gerais, Belo Horizonte, 2017.

Ribeiro, B. C. R. O. O ensino da dança em um projeto social do Programa Escola Aberta: questões para a construção do conhecimento e currículos pelo viés da educação somática. 2018. Dissertação (Mestrado em Educação) Faculdade de Educação, Pontifícia Universidade Católica de Minas Gerais, Belo Horizonte, 2018. 
Siqueira, D. C. O. Corpo, comunicação e cultura: a dança contemporânea em cena. Campinas: Autores Associados, 2006. 



\title{
CAPÍTULO 7
}

\section{RÁDIO, FUTEBOL E LAZER: A EXPERIÊNCIA DO ÓBVIO ULULANTE NA RÁDIO UFMG EDUCATIVA}

\author{
Elias Santos \\ Thiago José Silva Santana \\ Felipe Vinícius de Paula Abrantes \\ Marina de Mattos Dantas \\ Silvio Ricardo da Silva
}

Há no meio acadêmico uma dita polêmica em relação ao surgimento do lazer (Gomes, 2004, p. 133). Uns apontam que esse modo de vivência já existia em civilizações antigas; outros defendem que o lazer é fruto das mudanças trazidas na relação com o mundo do trabalho, pela Revolução Industrial. Outra polêmica diz respeito ao "tempo do lazer", ou seja, quando ele acontece. Estudos como os de Dumazedier (1979), referendados em pesquisas mais antigas, em sociedades menos dinâmicas, apontam que o tempo do lazer é separado do tempo do trabalho, é o tempo livre das obrigações cotidianas, é o tempo do final de semana, das férias ou da aposentadoria. Acompanhando as mudanças sociais que vieram com o passar dos anos e os avanços tecnológicos, estudiosos do lazer passaram a pensar esse momento como uma manifestação cultural acontecendo em uma relação dialética com o trabalho produtivo (Gomes, 2004, p. 125).

O lazer se expressa cotidianamente e das mais diferentes formas. Sua vivência (praticada ou fruída) tem relação estreita com o contexto cultural em que está inserido. As artes, os espetáculos, os esportes, as festas, os jogos, entre outras, são possibilidades de experiências de lazer. As escolhas dessas práticas sociais sofrem influências de vários agentes culturais, bem como também os influencia. Cabe destaque ao papel exercido pelos meios de comunicação nessa mediação cultural. Jornais, emissoras de 
rádios, canais de TV e a internet vêm sendo pensados, ora enaltecidos, ora criticados pela função de mediadores sociais e culturais que desempenham historicamente.

No Brasil, inicialmente tivemos os jornais cumprindo esse papel de mediador, porém de maneira tímida, até por conta do baixo número de pessoas alfabetizadas existentes no final do século XIX e início do século xx. A partir dos anos de 1930, o rádio iniciou uma trajetória de influenciador cultural que perdura até os dias atuais. Décadas depois, foi a chegada da TV e, mais recentemente, da internet, que impactou nossa sociedade na escolha de opções de lazer. Conforme aludido anteriormente, esses agentes de mediação cultural merecem sim a atenção do meio acadêmico, pois estimulam na sociedade posições diversas, que transitam entre a crítica ferina e a adoração. Neste texto, analisaremos o papel exercido pelo rádio e, mais especificamente, vamos falar de sua relação com o futebol, além de apresentar a experiência de um trabalho cultural e educacional desenvolvido por uma rádio universitária. O rádio é parte do lazer do brasileiro e está presente não só no tempo da desobrigação, mas também no tempo das obrigações, configurando-se talvez como um dos primeiros exemplos de vivência de lazer em uma relação dialética com o trabalho.

Durante boa parte do século xx pensou-se o rádio por uma única definição: veículo de comunicação de massa que transmite mensagens padronizadas para o ouvinte. $\mathrm{O}$ rádio seria também fruto da indústria cultural de massa, baseado exclusivamente em um paradigma informacional da comunicação no qual o emissor envia uma mensagem para ser decifrada pelo receptor. Assim, o rádio poderia caber em uma equação simples, de mão única, por vezes autoritária, pois permitia poucas manifestações culturais, sem diversidades e sem grandes possibilidades efetivas de interação. Considerado uma forma de lazer simples e pronta para a população, ou, como diria o pesquisador Tinhorão (1981, p. 70), o rádio seria "o teatro dos pobres dos grandes centros urbanos".

Porém a nossa proposta é pensar o rádio de forma mais ampla e complexa, apoiados em um paradigma interacional de comunicação, portanto, um paradigma mais contemporâneo e que trabalhe com uma interação maior entre emissores e receptores. Esse paradigma permite que as mensagens percorram um caminho mais circular e menos linear, com fissuras e ruídos próprios do processo cultural da comunicação. Desse modo, as diversas manifestações culturais constroem o rádio sem 
uma hegemonia e cabem dentro da concepção de lazer mais complexa, permeada por diversas práticas sociais. A ideia é trabalhar o rádio como um dispositivo multidimensional e formado por textos diversos, como explicaremos mais adiante. Mas o que seria um dispositivo?

A princípio propomos pensar o dispositivo como um lugar material ou imaterial independente, no qual os textos se inscrevem e são moldados - textos podem ser áudios, vídeos, fotografias, gráficos, textos escritos etc. Recorremos então ao conceito de dispositivo de Mouillaud e Porto (1997). Apesar de terem trabalhado com a análise de jornal em sua primeira definição de dispositivo, os autores ampliam a ideia: "os dispositivos são lugares materiais ou imateriais nos quais se inscrevem (necessariamente) os textos (despachos de agências, jornal, livro, rádio, televisão etc...)” (Mouillaud; Porto, 1997, p. 34). Assim, os dispositivos não são apenas suportes, mas matrizes fortes que influenciam diretamente nos textos. Podemos concluir que, a partir da inserção do dispositivo rádio nas redes sociais, os textos ganham uma dimensão mais ampla. Dispositivos e textos estão relacionados entre si, apesar de ambos existirem de forma independente um do outro. A relação é sempre dinâmica e tensa, a pressão do texto pode alterar fortemente o dispositivo, como também as mudanças no dispositivo podem influenciar na produção do texto. É dessa relação, constantemente em construção e tensionada, que nasce o sentido com sensações e significações abertas. Os sentidos também se podem abrir se levarmos em conta a relação entre diferentes dispositivos coexistentes, afinal um dispositivo não elimina o outro; os dispositivos podem até mesmo se encaixar, além de cada um poder trazer em si as marcas das condições de textualidade alteradas de outros dispositivos, ampliando mais uma vez os sentidos. Diante disso, podemos pensar que um dispositivo, mesmo independente, relaciona-se com outros dispositivos independentes, com a possibilidade de também neles se encaixar. $\mathrm{O}$ dispositivo independente é também capaz de convergir e transformar as diferentes textualidades moldadas, lembrando o conceito de mediamorfose de Roger Fidler (1997). Nesse conceito, o autor propõe pensarmos que os meios são capazes de se adaptar às novas mudanças tecnológicas (ideia de metamorfose), defendendo assim a complementaridade desses próprios meios, levando a reconfiguração de suas textualidades, e não a extinção de um meio pelo outro. No princípio há uma convergência, depois uma transformação, e assim os meios reconfigurados garantem sua sobrevivência e independência. A televisão não acabou com o rádio, 
mas alterou o rádio. A internet não vai acabar com a televisão, mas esse novo dispositivo está alterando a televisão e também o próprio rádio. Os dispositivos podem se alterar e ao mesmo tempo manter suas independências, provocando uma expansão nos sentidos dos textos.

Outra questão importante é pensar o dispositivo de uma forma multidimensional, considerando três dimensões que se relacionam: tecnologia, linguagem e sociedade. Com essa formulação, Mouillaud e Porto (1997) nos permitem ver o dispositivo como uma espécie de acoplamento estrutural formado pelas relações dessas três dimensões que se expressam nos processos de comunicação. $\mathrm{O}$ dispositivo não pode ser pensado apenas em sua dimensão tecnológica, pois a evolução técnica, a construção de textualidades e as relações sociais não estão separadas. Portanto, ao estudar um dispositivo, precisamos levar em conta, além dos textos e suas textualidades, o contexto histórico e sociocultural no qual estão inseridos dispositivos e textos.

Pensar um dispositivo independente e multidimensional é pensá-lo como um modo de relações materiais e imateriais nas quais os textos se apresentam. Sendo resultado da relação das entidades que o constituem, o texto deve ser compreendido como um todo, não como um conjunto de partes autônomas. Porém é preciso cuidado, porque um texto não deve ser entendido fechado nele mesmo, é preciso sair dele, é necessário perceber o texto e seus sentidos. As entidades que formam um texto não têm significado quando fechadas nelas mesmas, uma vez que precisam ser mobilizadas por um agente de comunicação, e a intenção dessa comunicação está tanto no emissor/autor quanto no receptor/leitor/ouvinte - aliás, um leitor/ouvinte ativo que participe interativamente na criação do texto. Aqui vale destacar que o humor e o riso, características tão marcantes não só do rádio como também do teatro de revista e do circo, são gestos comunicacionais e culturais que ampliam os sentidos dos textos, são ações do sujeito sobre o mundo e sobre o interlocutor, são gestos que pedem a esse interlocutor uma ação sensata sobre os textos, como propõe Ricouer (1991). Os textos nos auxiliam na construção do sentido da nossa experiência no mundo, e a comunicação é parte dessa experiência. A comunicação pode ser pensada como algo que está em nosso dia a dia, em nossos sentidos, em nossa compreensão e desfrute da vida cotidiana, em nossa percepção sensível do mundo, em nossa experiência de vida. A comunicação é ação, é a intervenção do sujeito no mundo, é o lugar da ação social e cultural entre os sujeitos, da reciprocidade, do 
diálogo, da interação, do ouvinte que em casa torce, retorce, diverte-se, se enfadonha, ri, chora, revolta-se com o programa de rádio.

Como um dos elementos constitutivos da cultura da mídia, o rádio está presente no Brasil desde a década de 1920. Naquela época, as primeiras emissoras de rádio foram implantadas no país e o veículo era considerado refinado e elitizado, voltado à veiculação da chamada alta cultura, ou melhor, da cultura erudita de origem europeia. Os estudos de José Ramos Tinhorão (1981) e Elias Saliba (2002) apontam essa característica e destacam que, durante a década de 1940, a programação do rádio brasileiro começaria a mudar: deixaria de ser cultural-elitista para tornar-se popular, jocosa e calorosa, baseada no humor anárquico oriundo do sucesso do teatro de revista e dos folhetins brasileiros. Esse riso provocado no ouvinte vinha de esquetes humorísticos, da apresentação de piadas no ar, das paródias musicais, dos jingles engraçados, das radionovelas de gêneros diversos, do show de calouros e de um lugar que misturava tudo isso: os programas de auditório. Esses quadros humorísticos tiveram sua origem principalmente nas peças do teatro de revista (influenciadas, por sua vez, pelas operetas europeias), que traziam em suas textualidades duas formas marcantes: o humor e a música. Mas tudo isso de forma ágil, pois, como aponta Saliba (2002), as salas de teatro da época apresentavam um ligeiro esquete humorístico, com música/dança antecipando as aguardadas projeções fílmicas. Daí a denominação de cineteatro para essas salas, espaços que os produtores culturais conseguiam viabilizar economicamente em sua manutenção, embora ainda elitizados. Eram algumas características desses esquetes que depois seriam aproveitadas para os programas de rádio: fala coloquial, humor rápido fruto de textos ligeiros mais músicas curtas, repetição de formatos, agilidade nas narrativas para dar dinamismo à apresentação. É por isso que os programas de rádio se tornariam espaços de encontros e sociabilidade das camadas mais populares brasileiras. Interessante notar que tal estratégia baseada no humor ainda perdura até hoje em diferentes estilos de rádio: populares, jovens, educativas e até mesmo nas atuais rádios de notícias vinte e quatro horas (BandNews e $\mathrm{CBN}$ ), que têm adotado cada vez mais um tom coloquial e irônico na locução.

Assim, o rádio começaria a consolidar-se no Brasil de forma majoritariamente comercial, vivendo nos anos de 1940/1950 a sua "era de ouro". Os ouvintes da época começaram a visitar as emissoras de rádio para conhecer de perto seus artistas e radialistas prediletos. Quem era o 
dono daquela voz que entrava na casa dos ouvintes, tornava-se íntima e cravava um diálogo mental com toda a família? Os produtores perceberam que a presença física dos ouvintes nas emissoras trazia calor à programação e gerava adesão do público, ou seja, a audiência aumentava consideravelmente. E ainda hoje os ouvintes querem ver e acompanhar o perfil dos radialistas nas redes sociais e, se possível, visitar as emissoras de rádios em seus momentos de lazer. Dessa maneira, as emissoras de rádio passaram a investir em atrações mais interativas e divertidas, que dessem ao ouvinte a sensação de proximidade com o meio fazendo uso de uma linguagem simples, coloquial e oral. Foram criados programas de auditório, radionovelas, revistas de variedades, programas de debate de diversos assuntos, e outros mais que pudessem abrigar as diversas manifestações culturais brasileiras e entreter o ouvinte.

A música é um dos elementos sonoros importantes na construção das textualidades dos diversos programas de rádio, e na televisão não foi diferente. Porém as textualidades não são estáticas, há uma dinâmica de mudanças e transformações dos textos, expandindo sempre os seus sentidos. Segundo o pesquisador Luiz Tatit (2004), a televisão brasileira pode ser considerada uma mixórdia (mistura desordenada de coisas diversas, uma confusão), que de certa forma reflete uma característica da cultura brasileira de assimilação. Se em um incipiente primeiro momento, nos anos de 1950, os programas de auditório da televisão foram chamados por Tinhorão (1981) de "rádio filmado", sem grandes inovações, nos anos de 1960 a televisão começaria sua consolidação no Brasil, que em parte aproveitaria o momento de explosão da música brasileira na própria televisão, culminando com os novos programas de auditório musicais criados para TV, como Jovem Guarda (Roberto Carlos), O Fino da Bossa (Elis Regina e Jair Rodrigues), Festivais da Canção (Excelsior, Record e Globo), entre outros. A música continuaria fazendo parte dos programas de auditório, mas de forma diferente, pois a música brasileira trazia novidades, como o movimento Tropicalista. Segundo Tatit (2004), um dos pontos importantes desse movimento para a canção brasileira estaria na ideia da mistura, da geleia geral, da assimilação de estilos diversos, de dizer não à exclusão. Assim, ocupar os diversos espaços seria essencial, entre eles os programas de auditório da televisão, do irreverente Chacrinha ao novo Jovem Guarda, com polêmicas passagens pelos Festivais da Canção e discussões com Flávio Cavalcanti. Os tropicalistas apostavam suas fichas na diversidade cultural multicolorida e multissonora do Brasil; e os 
programas de auditório, desde a época do rádio e com as influências do teatro de revista e do circo, traziam essa diversidade e esse excesso como características marcantes.

\section{Futebol e rádio}

Na relação entre os esportes e os meios de comunicação, o futebol está fortemente presente desde o início do século $\mathrm{xx}$, notadamente nos noticiários dos jornais impressos. Ainda naquele iniciante período do futebol no Brasil, havia jornais e jornalistas entusiastas desse esporte, mas havia também aqueles que atacavam essa nova prática dizendo que ela não "pegaria" no Brasil. Porém, como sabemos, o futebol "pegou", e essa relação "simbiótica" futebol-mídia parece estar a cada dia mais forte.

Após o advento do rádio no Brasil, esse meio de comunicação de massa se aproximou e apropriou-se do futebol enquanto conteúdo. Nos anos de 1930, o futebol já havia conquistado certa popularidade no país e o processo de profissionalização do esporte começou a se desenrolar nessa mesma época. É também nesse período que tivemos o início das transmissões das partidas de futebol pelo rádio. Vale ressaltar que os noticiários e a falação esportiva (Eco, 1984) já ocorriam antes mesmo das transmissões das partidas. Segundo Tota (apud SoAres, 1994), as transmissões com essa abordagem do futebol começaram na década de 1920. No que se refere a transmissões de partidas de futebol, atribuiu-se a Rádio Educadora Paulista a primeira transmissão de uma partida, feita por Nicolau Tuma em 1931 (SoAREs, 1994). O estilo de narração de Tuma caracterizava-se por impor um ritmo acelerado descrevendo todos os lances da partida, o que mais se aproximaria das formas atuais de narrar o futebol. Essa característica teria lhe rendido o apelido de speaker metralhadora (SoAREs, 1994). Além desse marco, é importante destacar que houve uma combinação de fatores que fizeram com que a "tabelinha" entre futebol e rádio se consolidasse. Como afirmado, a profissionalização do futebol era um processo em andamento, e o rádio e suas transmissões alcançavam naquela época cada vez mais pessoas, de modo que os dirigentes dos clubes viram esse meio como um importante fator de divulgação e difusão do futebol no Brasil. Em relação à importância do rádio para a difusão do futebol, um emblemático exemplo é o da Rádio Nacional. Sediada na cidade do Rio de Janeiro, então capital federal, a Rádio Nacional era a emissora que tinha o maior 
alcance dentro do território brasileiro, e assim as transmissões futebolísticas chegavam aos mais distantes rincões do Brasil. Como a emissora se localizava no Rio de Janeiro, as transmissões eram dos jogos de clubes cariocas, e a evidência dessa força do rádio para a difusão e divulgação do esporte se traduz hoje no grande número de torcedores desses clubes em regiões bastante afastadas Brasil afora.

Contudo, inicialmente alguns dirigentes não enxergaram esse benefício, pois com a profissionalização do futebol os clubes teriam mais despesas envolvidas e a bilheteria das partidas era a principal fonte de renda. Existia o receio de a transmissão radiofônica das partidas contribuírem para a diminuição do número de pessoas presentes nos estádios. Com esse temor, houve a tentativa de proibição das transmissões, mas logo se percebeu que o papel do rádio era exatamente o oposto: o de contribuir para a difusão do futebol e, consequentemente, para a presença cada vez maior de torcedores nos campos (DiAs; Lima, 2011).

Principalmente a partir dos anos de 1970, o rádio deixou de ser a principal forma midiática de transmissão de partidas e de programas esportivos. Naquele período, a televisão começou a ocupar um lugar de protagonismo. Contudo o rádio nunca deixou de ser um importante veículo midiático, promovendo e propagando o futebol para várias regiões e pessoas, pois, como apontado anteriormente, na mediamorfose alguns dispositivos de comunicação não deixam de existir diante da hegemonia de outros, mas transformam suas formas de fazer comunicação.

Dessa maneira, o próprio rádio passou por transformações que o colocaram e o mantiveram como uma relevante ferramenta de comunicação até os dias atuais. Um exemplo disso são as web rádios e os podcasts. Apesar de não serem componentes das tradicionais emissoras, uma vez que é pela internet que são promovidos, recorrem fortemente aos modelos das rádios tradicionais. Outro aspecto interessante desse novo formato de emissão de áudio é a possibilidade de popularização e democratização na produção do conteúdo a ser consumido, colaborando até mesmo na difusão das rádios tradicionais. Em relação ao futebol, muitas dessas web rádios e podcasts são produzidos por torcedores e outros comunicólogos independentes, trazendo um protagonismo a eles nunca antes observado.

Assim, uma das razões do sucesso do rádio parece estar em sua capacidade de estabelecer interlocução com as pessoas, retrabalhando elementos de sua vida ordinária, ao mesmo tempo em que dela participa 
permitindo momentos de lazer por meio de um desfrute da vida cotidiana. Muitas vezes os programas de rádio parecem brincar (e, às vezes, caricaturar) a realidade cotidiana, sendo que, ao fazê-lo, reiteram valores, práticas sociais, normas e padrões estéticos profundamente enraizados. Os programas de rádio podem dizer tanto de nós mesmos como da nossa relação com o mundo, por isso eles são objetos de estudos importantes sobre a dimensão da nossa experiência humana, como lembra Silverstone (2002) em sua proposta de por que devemos estudar a mídia. O esporte, o lazer e a música são manifestações culturais que fazem parte da nossa relação cotidiana com o mundo, portanto marcam nossa experiência humana, daí a importância da presença desses elementos na programação de uma emissora de rádio. Essas manifestações culturais transformaram-se em produtos altamente rentáveis para as emissoras de rádio, mas invariavelmente dentro de abordagens padronizadas e comerciais. O público sempre mostrou grande interesse por tais expressões da cultura, mas é necessário abordar o assunto como algo não padronizado, afinal de contas a experiência humana no mundo é muito rica e diversa, e isso não é diferente com o esporte, o lazer e a música. Diante disso, seria possível abordar, por exemplo, o futebol de maneira educativa, diferente e leve? Caberia dentro da programação de uma rádio universitária pública educativa um espaço para esse tipo de abordagem? Acreditamos que sim, e esse desafio mostrou-se enorme e necessário.

Em 6 de setembro de 2005 entrou no ar a Rádio UFMG Educativa FM 104,5, um canal educativo de rádio operando na região metropolitana de Belo Horizonte, por meio de uma parceria inédita entre a antiga Radiobrás (atual Empresa Brasil de Comunicação - EBC) e a Universidade Federal de Minas Gerais (UFMG). Segundo o Ministério das Comunicações, uma rádio educativa é um serviço de radiodifusão sonoro destinado à transmissão de programação educativo-cultural. Por meio desse modelo de rádio, se oferecem serviços de natureza educacional, cultural, pedagógica e de orientação profissional. No entanto essa é uma definição muito ampla e vaga para trabalhar, e foi necessário elaborar conceitos mais consistentes para construir uma linha editorial formada por um tripé que definisse melhor aquilo que se pretendia.

Em primeiro lugar, era preciso que a emissora desse visibilidade à UFMG. Dentro da ideia de que o trabalho acontecia em uma universidade pública, era preciso mostrar para a sociedade os projetos de pesquisa, ensino e extensão que compunham a missão da instituição e 
também o que a universidade tinha a dizer sobre os assuntos do nosso cotidiano. Muitas vezes as universidades têm pouco espaço na grande mídia (vestibulares, resultados de grandes pesquisas, escândalos, greves mais extensas etc.), e isso dificulta uma melhor compreensão por parte da sociedade da importância de uma universidade pública. A Rádio UFMG Educativa entendeu desde a sua formação que a visibilidade serve tanto para a divulgação de projetos quanto para certa prestação de contas com a sociedade, ainda mais se considerarmos o momento difícil pelo qual estão passando as instituições públicas do nosso país. Nesse meio de comunicação, o objetivo não era falar da UFMG durante vinte e quatro horas, daí a importância do respeito aos critérios de noticiabilidade, pertinência e interesse público - era preciso respeitar também as características do dispositivo rádio e as formas de recepção com as quais o ouvinte está acostumado a lidar, ou seja, com certo modo de ouvir rádio.

Em outro ponto do tripé encontrava-se a possibilidade de a rádio servir como espaço de formação complementar dos alunos, professores e funcionários da universidade. É fácil perceber essa dinâmica com relação aos alunos dos cursos de comunicação e engenharia; no entanto, em plena sociedade dita da informação, acreditava-se que todos os cidadãos deveriam conhecer um pouco melhor os processos dessa construção utilizados pelos meios de comunicação, assim teríamos um público mais crítico e com melhores ferramentas para selecionar a avalanche de informações a que está sujeito na sociedade contemporânea. Um cidadão pleno também deve saber exercer seu direito de selecionar e criticar as informações que recebe, independentemente de sua área de atuação. Acertando formatos, conteúdos e horários diferentes, procurou-se adequar às demandas que surgiam montando nossa grade de programação sempre respeitando o personagem principal de todo esse processo: o ouvinte.

Para finalizar nosso tripé, um conceito não menos importante: era necessário que a emissora oferecesse ao público ouvinte de rádio da região metropolitana de Belo Horizonte uma programação alternativa à de outras emissoras locais. É fundamental que um canal educativo de rádio, ligado a uma universidade pública, ouse criando formatos diferentes, fale de assuntos nunca tratados, experimente locuções e paisagens sonoras alternativas. Não era objetivo da rádio falar apenas da UFMG, e também não estava nos planos da emissora ser experimental em toda a 
sua programação, uma vez que haveria momentos para isso, além de se acreditar que o ouvinte é capaz de selecionar o seu "cardápio".

Nesse contexto, tendo como base a vertente editorial previamente definida, entrou no ar, em 20 de maio de 2010, um programa de futebol promovendo intenso debate de ideias, produzido em parceria com o Grupo de Estudos sobre Futebol e Torcidas (GEFuT) da Escola de Educação Física, Fisioterapia e Terapia Ocupacional da UFMG.

Com o nome de Óbvio Ululante, o programa nasceu como um projeto de extensão do GEFuT, produzido em parceria com a Rádio UFMG Educativa e realizado desde o ano de 2010. A sua idealização data do segundo semestre do ano de 2009, quando a Rádio UFMG, interessada em realizar um programa que abordasse o futebol de maneira diferenciada daquela utilizada pela mídia tradicional, convidou o GEFuT para produzi-lo.

O nome é uma homenagem a Nelson Rodrigues (1993), que entendia o futebol como um fenômeno complexo, ao contrário daqueles por ele chamados de "idiotas da objetividade", que tratavam o futebol por uma lógica exclusivamente racional. Dessa forma, o que o programa veio com a proposta de pensar o futebol para além da busca de respostas prontas e provocar questionamentos e reflexões, "Porque no futebol nada é tão óbvio assim”, como diz seu slogan (Melo et al., 2012).

Ao longo dos anos, o programa mudou a forma e o dia de sua transmissão, que inicialmente era gravado, passando a ser ao vivo no ano de 2011. Nos dias atuais, o programa vai ao ar semanalmente, às quartas-feiras, a partir das 18h10, com duração de cinquenta minutos. O formato conta com quatro blocos nos quais são realizados os quadros temáticos e seus comentários. Há participação de colunistas mensais, discussão de assuntos atuais do futebol e entrevistas com convidados. Os blocos são intervalados por anúncios institucionais.

A produção do programa é realizada voluntária e coletivamente pelos pesquisadores do GEFuT que trabalham diretamente com o projeto. Cada programa é preparado pela equipe responsável e discutido em grupo no aplicativo WhatsApp e em uma lista de e-mails em que as pessoas envolvidas podem opinar sobre a temática e saber quais quadros serão produzidos pela equipe.

Os quadros possuem uma ementa pensada coletivamente e servem de norte para a produção dos pesquisadores, que têm a liberdade de criar textos extrapolando, eventualmente, o formato preestabelecido pelas 
ementas. A cada semana, três pesquisadores são responsáveis por produzir os quadros que farão parte do roteiro semanal do programa.

Os temas abordam diversas dimensões do futebol, como sua história, personagens e personalidades de dentro e de fora dos gramados, estádios, fatos e casos curiosos do esporte, o futebol nas diversas artes, dicas de filmes, eventos e exposições na cidade, bem como a produção acadêmica a respeito do futebol - em particular a realizada no campo das ciências humanas.

Além dos quadros, há duas colunas mensais intituladas "Mulheres em campo" e "Hat trick". A primeira trata de questões correlatas ao futebol praticado por mulheres e a segunda aborda de forma sucinta três eventos atuais relacionados ao universo do futebol. Eventualmente o programa também conta com entrevistas com pessoas que possuem diversas ligações com o futebol. Já foram entrevistados(as) jornalistas, ex-jogadores(as), torcedores(as), pesquisadores(as) do futebol, entre outros(as). Além disso, a fim de ressaltar o caráter do futebol enquanto fenômeno cultural, são reproduzidas no programa músicas de variados estilos que tratam desse esporte em suas letras.

O programa tem um âncora que é responsável pela organização dos roteiros. Ao longo dos anos, essa função foi exercida por estudantes do curso de comunicação da universidade. Além disso, a Rádio UFMG Educativa disponibiliza o estúdio e o apoio de seus técnicos em comunicação para que o programa possa ser realizado ao vivo, no rádio e na internet.

O Óbvio Ululante também está presente para além das ondas do rádio. A partir de 2015 foram criadas páginas e perfis nas principais redes sociais (como Facebook, Instagram, Twitter e WhatsApp) ${ }^{1}$ para divulgar e criar um canal mais dinâmico e interagir com o público do programa. Essa convergência de dispositivos tecnológicos (o rádio e a internet) são ferramentas importantes que possibilitam melhor comunicação com o público, permitindo que as mensagens percorram um caminho mais circular e menos linear, tal qual foi apontado anteriormente, estabelecendo diálogos entre emissores e receptores envolvidos no processo.

1 Os endereços das redes sociais do programa são: <https://www.facebook.com/ ObvioUlulanteUFMG >; $<$ https://www.instagram.com/obvioululanteufmg/ $>$; $<$ https:// twitter.com/ObvioUFMG >; e o número disponível para o aplicativo WhatsApp: (31) 97577-8713. 
Em sua página no Facebook, o programa é transmitido em vídeo ao vivo, combinando a imagem, que a princípio seria um recurso próprio da televisão, com um programa produzido no rádio.

O Óbvio Ululante busca se diferenciar dos programas esportivos da mídia comercial lançando mão de uma abordagem particularizada do futebol e da democratização da informação por meio da divulgação científica. Ao se diferenciar da mídia comercial, o programa busca afastar-se do que Eco (1984) define como falação esportiva, que se restringe a abordar aspectos pontuais do futebol, como elabora Betti (2001). O que, segundo o autor, faz com que boa parte da mídia esportiva priorize a forma em detrimento do conteúdo, tornando a cobertura do esporte superficial e factual - embora Betti (2001) também pondere que, em virtude das limitações de cada mídia e das funções que desempenham, não seja possível abordar o esporte em todas as suas dimensões.

Na produção dos quadros ou em seus comentários, procura-se relacionar de maneira objetiva o tema tratado com a produção acadêmica, sem contudo tornar a discussão entediante. Com isso, por considerar o futebol e o rádio como importantes formas de lazer no Brasil, o programa busca, pela sua dimensão educativa, tratar o futebol em sua dimensão cultural e trazer, com leveza e humor, questões sociais imbricadas nas diversas formas de se relacionar com esse esporte.

Dessa forma, o programa objetiva dar visibilidade para outros temas que não encontram tanto espaço na mídia comercial, tratar de questões que trazem grupos marginalizados, como a população LGBT, problematizar o machismo no futebol, contribuir para a ampliação da visibilidade do futebol praticado por mulheres, entre outros. Assim, o Óbvio espera poder tirar o público ouvinte do lugar comum ao trazer questões que possam provocar reflexões sobre outros temas pouco visados pela mídia comercial no contexto do futebol.

Ademais, como dito anteriormente, o fato de o programa ser produzido no contexto de uma universidade pública faz com que também tenha como finalidade contribuir com a democratização da ciência, o que faz ao levar aos seus ouvintes o resultado de pesquisas desenvolvidas no âmbito da universidade, sejam elas realizadas por integrantes do GEFuT ou por outros grupos de pesquisa que tematizam o futebol no âmbito das ciências humanas.

Cabe ressaltar que a divulgação científica é aqui entendida como "a veiculação em termos simples da ciência como processo, dos princípios 
nela estabelecidos, das metodologias que emprega" (REIS, 2002, p. 76). Albagli (1996, p. 398), ao refletir sobre as motivações da divulgação científica, afirma que entre estas está o esclarecimento da sociedade a respeito dos impactos sociais da ciência e tecnologia. A importância da divulgação científica é tratada também por Werneck (2002) ao ressaltar que a população brasileira é escassamente informada sobre as atividades dos pesquisadores e instituições. Diminuir a distância entre o conhecimento produzido pela universidade e os demais setores da sociedade é importante para ampliar o suporte social dado às universidades e instituições científicas e o Óbvio Ululante visa contribuir para isso.

Dessa maneira, a ação de divulgação científica que o Óbvio Ululante realiza está em consonância com o conceito de extensão universitária descrito na Política Nacional de Extensão Universitária (Forproex, 2012, p. 28), que afirma:

A Extensão Universitária, sob o princípio constitucional da indissociabilidade entre ensino, pesquisa e extensão, é um processo interdisciplinar, educativo, cultural, científico e político que promove a interação transformadora entre Universidade e outros setores da sociedade.

Em adição a esse conceito, é pertinente relembrar os pilares da Rádio UFMG Educativa, que são a oportunidade de formação complementar aos alunos, professores e servidores da UFMG por meio de uma programação alternativa e diversificada e a divulgação da produção acadêmica, científica e de serviços.

Buscamos apresentar aqui a experiência do GEFuT em parceria com a Rádio UFMG Educativa por intermédio do projeto de extensão e programa de rádio Óbvio Ululante. O futebol e o rádio são marcantes na história do Brasil, já que os dois tiveram uma importante participação na constituição da ideia de nação e ainda nos dias atuais são importantes formas de lazer. Considerando o potencial educativo do rádio e o futebol enquanto fenômeno cultural, que é veiculado pelos diversos meios de comunicação, entendemos o programa Óbvio Ululante como uma ferramenta de mediação cultural que leva a seus ouvintes e seguidores nas redes sociais uma abordagem diferenciada sobre o futebol. 


\section{Para além do Óbvio Ululante}

Do início do século xx para o início do século XxI, o rádio como dispositivo de comunicação passou por diversas transformações, adaptando-se, mas também reinventando os tempos pelos quais atravessou. Falar em rádio na atualidade é levar em consideração uma comunicação dinâmica, em que emissores e receptores se confundem, estabelecendo uma relação mais horizontal que as estabelecidas em seus primórdios.

Nesse sentido, as relações entre rádio e lazer na atualidade se constroem também nesse diálogo ativo, como exposto neste capítulo, retrabalhando elementos da vida dos ouvintes ao mesmo tempo em que estes também contribuem na construção desse dispositivo de lazer.

Se as relações entre rádio e meios de comunicação se modificaram no passar do tempo cronológico, muito em razão das transformações também ocorridas nesse esporte, podemos afirmar que nem tudo é sempre tão óbvio que não possa ser (re)pensado. E é reconhecendo que o óbvio que ulula tem suas construções calcadas em realidades políticas, históricas, culturais e sociais (nas quais o futebol também se inclui) que o programa Óbvio Ululante da Rádio UFMG Educativa faz o exercício de romper com a suposta imparcialidade do jornalismo esportivo tradicional. Evitamos, dessa maneira, repercutir as polêmicas esvaziadas de sentido, para propor reflexões que estabeleçam interlocuções entre pesquisas acadêmicas e o cotidiano do jogar e do torcer (e de outras formas de se viver o futebol), saindo do futebol para além da bola rolando e mirando nas construções sociais que o permeiam nessa difícil tarefa de fazer da construção do conhecimento algo que possa ser agradável.

A isenção das demandas comerciais das quais as rádios universitárias são isentas colaboram com uma satisfatória liberdade na seleção, elaboração e exposição do conteúdo apresentado aos e às ouvintes, nos permitindo "rolar a bola" em campos socialmente delicados, como os dos racismos, construções de gênero, e também abordar outras desigualdades e diferenças que no futebol se fazem presentes e para as quais temos nosso olhar atento.

Esse é um exercício transdisciplinar para tratar de temáticas sociais que não somente se refletem no futebol, mas também emergem dele e das relações que as pessoas estabelecem entre si e com o esporte nessa "tabelinha" entre o futebol, o lazer e o rádio. 


\section{Referências}

Albagli, S. Divulgação científica: informação científica para cidadania. Ciência da Informação, Brasília, v. 25, n. 3, p. 396-404, set./dez. 1996.

Betti, M. Esporte na mídia ou esporte da mídia? Revista Motrivivência, Florianópolis, ano XII, n. 17, p. 1-3, set. 2001.

DiAs, E. S.; Lima, C. G. Da emoção à descrição: a história da narração esportiva no rádio. In: Encontro Nacional De História Da Mídia, 8., 2011, Guarapuava. Anais... Guarapuava: Unicentro, 2011.

Dumazedier, J. Sociologia empírica do lazer. São Paulo: Perspectiva, 1979.

Eco, U. Viagem na irrealidade cotidiana. Rio de Janeiro: Nova Fronteira, 1984.

FIDleR, R. Mediamorphosis: understanding new media. Londres: Sage Publications, 1997.

Forproex - Fórum de Pró-Reitores das Instituições Públicas de Educação Superior Brasileiras. Política Nacional de Extensão Universitária. Manaus: Forproex, maio 2012.

Gomes, C. L. (Org.). Dicionário crítico do lazer. Belo Horizonte: Autêntica Editora, 2004.

Massarani, L. A divulgação científica no Rio de Janeiro: algumas reflexões sobre a década de 20. Dissertação (Mestrado) - Universidade Federal do Rio de Janeiro, 1998.

Melo, M. A.; Anjos, L. A.; Lages, C. E. D. M.; Braga, L. G. G.; Abrantes, F. V. P. A escola e o rádio como possibilidades de construção de conhecimentos e de diálogo com a sociedade tendo o futebol como eixo os projetos de extensão do GEFuT. In: Silva, S. R.; Debortoli, J. A. O.; Silva, T. F. (Org.). O futebol nas Gerais. Belo Horizonte: Editora UFMG, 2012.

Mouillaud, M.; Porto, S. D. O jornal: da forma ao sentido. Brasília, DF: Paralelo, 1997.

Reis, J. Ponto de vista: José Reis. In: Massarani, L.; Moreira, I. C.; Brito, F. (Org.). Ciência e público: caminhos da divulgação científica no Brasil. Rio de Janeiro: Casa da Ciência - Centro Cultural de Ciência e Tecnologia da Universidade Federal do Rio de Janeiro, 2002. (Fórum de Ciência e Cultura).

Ricouer, P. Do texto a acção: ensaios de hermenêutica II. Porto: Res, 1991.

Rodrigues, N. O Óbvio Ululante: primeiras confissões crônicas. São Paulo: Companhia das Letras, 1993. 
SAliba, E. T. Raízes do riso: a representação humorística na história brasileira - da Belle Époque aos primeiros tempos do rádio. São Paulo: Companhia das Letras, 2002.

Silverstone, R. Por que estudar a mídia? São Paulo: Edições Loyola, 2002.

SoAres, E. A bola no ar. São Paulo: Summus, 1994.

TAtit, L. O século da canção. Cotia: Ateliê Editorial, 2004.

Tinhorão, J. R. Música popular: do gramofone ao rádio e TV. São Paulo: Ática, 1981.

Tota, A. P. A locomotiva no ar: rádio e modernidade em São Paulo. São Paulo: PW Gráficas e Editores; Secretaria de Cultura do Estado de São Paulo, 1990.

Werneck, E. F. E por falar em ciência... no rádio! In: Massarani, L.; Moreira, I. C.; Brito, F. Ciência e público: caminhos da divulgação científica no Brasil. Rio de Janeiro: Casa da Ciência; Centro Cultural de Ciência e Tecnologia da Universidade Federal do Rio de Janeiro, 2002. (Fórum de Ciência e Cultura). 



\section{CAPÍTULO 8}

\section{O ESPORTE COMO CONTEÚDO DE PROJETOS SOCIAIS}

Juan Carlos Pérez Morales

Gilmar Tondin

Luciano Pereira da Silva

\section{Esporte, educação e projetos sociais}

O esporte é atualmente um fenômeno universal, que ultrapassa barreiras físicas e imaginárias, movimenta o mercado financeiro e desperta paixões. Celebrado em grandes eventos esportivos, como os Jogos Olímpicos de Verão e de Inverno, também está presente no cotidiano da população que vê competições na televisão, acompanha o dia a dia do seu ídolo esportivo e tem como hábito de lazer, por exemplo, jogar uma pelada nos fins de semana. Além disso, o esporte também está nas escolas como um dos principais conteúdos da educação física escolar e ainda compõe com frequência as atividades oferecidas por projetos sociais, sobretudo aqueles direcionados à juventude.

$\mathrm{O}$ esporte pode ser entendido como uma atividade corporal do movimento humano, de caráter competitivo, surgido em meio à cultura europeia por volta do século XVIII (BRACHT, 1989). Nasceu pela transformação de elementos da cultura corporal do movimento, aqui envolvidas as classes populares e a nobreza inglesa. Surgido na Inglaterra, foi considerado um produto da ascensão da nova forma da organização social capitalista (GoNZÁLEZ, 2006).

O desenvolvimento e a ascensão dos esportes ingleses como uma prática de lazer foram bem acolhidos pela sociedade à época porque incentivavam o espírito competitivo (LuCENA, 2001). Assim, a vontade de vencer nas práticas esportivas deveria estar presente também na vida, 
características estas próprias do processo de industrialização, então iniciado na Inglaterra.

Nesse período, os jogos tradicionais ligados às festas (religiosas, colheitas, estações do ano, entre outras), seguindo uma tendência hegemônica, esportivizaram-se, como a ginástica e o judô (BRACHT, 1989), e estão avançando cada vez mais em terrenos nos quais antes não se imaginaria que andassem, como a yoga competitiva - esta mais recentemente criada.

Desde seu surgimento nas public schools da Inglaterra, destacou-se o caráter educacional do esporte. Ao longo dos anos, o potencial formativo do esporte tem sido apregoado em muitas instâncias sociais com diversos objetivos: formar corpos fortes e adestrados, forjar o caráter, afastar dos vícios. Atribui-se ao fenômeno esportivo poderes quase ilimitados, como se a simples presença da vivência esportiva em qualquer ambiente já garantisse uma série de benesses.

Sem duvidar do potencial educativo do esporte, acreditamos ser importante ressaltar que os ganhos que sua prática pode trazer dependem necessariamente de como ele é trabalhado. Como afirmou Parlebas (1997, p. 12), “o desporto não possui nenhuma virtude mágica. Ele não é em si mesmo nem socializante nem antissocializante. É conforme: ele é aquilo que se fizer dele. A prática do judô ou do rugbi pode formar tanto patifes como homens perfeitos preocupados com o 'fair-play". Nessa mesma lógica, Belbenoit (1976, p. 54) defende que "o esporte não é educativo a priori. É o educador que precisa fazer dele ao mesmo tempo um objeto e um meio de educação".

Nesse sentido, direcionamos o principal argumento deste texto: a importância de aquele que trabalha com atividades esportivas em ambientes educacionais formais (como escolas, clubes, projetos sociais) adotar propostas pedagógicas adequadas. Tal conhecimento pedagógico irá traduzir-se em conteúdos e procedimentos intencionalmente escolhidos para o alcance de determinados objetivos.

A pedagogia, de modo geral, trata das condições e possibilidades do processo educativo. Especificamente, a pedagogia dos esportes aborda referências teórico-práticas que subsidiam o processo de ensino-aprendizagem das modalidades esportivas.

Na produção acadêmica sobre políticas públicas de esporte, manifesta-se o debate sobre as dimensões desse fenômeno no intuito da defesa de qual delas deve ser privilegiada pelas ações públicas. A partir do final dos anos de 1990, esse debate passa a ser balizado pela Lei Pelé 
(lei n. 9.615/1998), que reconhece, em seu artigo $3^{\circ}$, que o esporte pode ter as seguintes manifestações:

I - desporto educacional, praticado nos sistemas de ensino e em formas assistemáticas de educação, evitando-se a seletividade, a hipercompetitividade de seus praticantes, com a finalidade de alcançar o desenvolvimento integral do indivíduo e a sua formação para o exercício da cidadania e a prática do lazer;

II - desporto de participação, de modo voluntário, compreendendo as modalidades desportivas praticadas com a finalidade de contribuir para a integração dos praticantes na plenitude da vida social, na promoção da saúde e educação e na preservação do meio ambiente;

III - desporto de rendimento, praticado segundo normas gerais desta Lei e regras de prática desportiva, nacionais e internacionais, com a finalidade de obter resultados e integrar pessoas e comunidades do País e estas com as de outras nações [BRAsIL, 1998].

Nesse debate, é relevante destacar que nossa Constituição estabelece que os recursos públicos devem ser investidos prioritariamente na manifestação educacional do esporte, apesar de percebemos que na prática não é isso o que acontece.

É claro que em um primeiro momento é necessário distinguir essas diferentes manifestações, pois em parte elas possuem dinâmicas específicas. Por exemplo, de acordo com Korsakas e Rose Junior (2002), a implementação de uma pedagogia do rendimento retira do esporte seus aspectos lúdicos e infantis, pois o foco está nos possíveis futuros atletas profissionais, e não nas crianças que brincam. O objetivo então é "transformar a criança que joga brincando em um atleta que rende jogando" (Korsakas; Rose Junior, 2002, p. 87).

O ensino do esporte nos ambientes formais de educação, como a escola, ou nos espaços extraescolares, como os clubes, exige do profissional que lida com esse conteúdo uma preparação que vai muito além do domínio dos gestos técnicos, ou das condições para que eles sejam executados/reproduzidos. Dizer que a aprendizagem esportiva baseia-se no gesto técnico é o mesmo que dizer que a aprendizagem em geral baseia-se na obtenção de informação. De acordo com Freire (2005), ensinar não é transmitir conhecimento, é criar as condições para sua construção e adequada aplicação. 
A pedagogia do esporte, segundo Barbanti (2003), pode ser definida como uma relação entre o esporte e a educação, para a oportunização de adequados processos que visam desenvolver habilidades e capacidades físicas, técnicas, táticas, cognitivas e emocionais, além de melhorar a qualidade de vida do ser humano.

Os métodos de ensino dos esportes coletivos comumente são classificados em tradicionais e inovadores. Tais métodos se baseiam, respectivamente, no ensino das técnicas inerentes a cada modalidade e na aprendizagem tática.

Os métodos tradicionais são denominados de tecnicistas, em que a aprendizagem (repetição) dos gestos técnicos de cada modalidade constitui o objetivo e o núcleo central de cada aula ou sessão de treinamento. Já os métodos inovadores visam à superação da simples repetição dos movimentos. Entre os métodos inovadores, é comum a busca pela formação de um aluno inteligente, criativo e autônomo, que reflete taticamente sobre o jogo, superando uma aprendizagem mecânica.

Ao pensarmos em uma pedagogia para o esporte, sobretudo com foco na aprendizagem esportiva, acreditamos que os conteúdos e procedimentos a serem adotados em escolas, clubes e projetos sociais aproximam-se, pois em todos esses cenários almeja-se a formação integral de seus participantes, o que envolve o conhecimento do esporte em sua complexidade. Entretanto, em virtude da tendência de se compreender as dimensões educacional e de rendimento como manifestações antagônicas, muitas vezes os projetos sociais acontecem em locais em que a prática esportiva desconsidera muito do que já foi desenvolvido sobre a pedagogia do esporte, baseando suas atividades em vivências recreativas de esporte.

Diante do contexto apresentado, este capítulo discute as interfaces e as relações entre algumas das teorias gerais da aprendizagem e o processo de aprendizagem esportiva que, a nosso ver, podem subsidiar a pedagogia do esporte nos projetos sociais. É importante evidenciar que o aqui exposto não esgota as possibilidades pedagógicas para o esporte nesse ambiente ${ }^{1}$. Assim, destacamos as propostas da Escola da Bola (KrögER; Roth, 2002) e da Iniciação Esportiva Universal (Greco; BendA, 1998). Posteriormente, na última seção do capítulo, serão apresentadas

1 Para outras propostas pedagógicas, ver Machado, Galatti e Paes (2015). 
atividades voltadas para o ensino dos esportes que podem compor o repertório a ser desenvolvido em projetos sociais.

\section{Processo de ensino-aprendizagem dos esportes: teorias de aprendizagem e sua relação com os modelos de instrução}

O processo de ensino-aprendizagem dos esportes da iniciação ao alto nível de rendimento apoia-se no adequado planejamento de conteúdos e atividades que favoreçam o desenvolvimento de capacidades, habilidades e competências, visando à interação e à complementaridade desses elementos na realização da ação esportiva. Entendemos a ação no esporte como uma relação de valência e competência entre a pessoa, o ambiente e a tarefa, regulada pelo sistema cognitivo, emocional e automático (Nitsch, 2009). Nesse sentido, é essencial que o professor planeje e estruture cuidadosamente os conteúdos e as atividades que comporão a aula, sessão ou treinamento de determinada modalidade esportiva, isto é, que possibilite o alcance dos objetivos propostos por meio do planejamento dos conteúdos e das atividades da modalidade esportiva em questão. Portanto, torna-se fundamental entender a importância da escolha do modelo de instrução nesse processo (MetZler, 2011). A compreensão das teorias de aprendizagem em que se apoiam os diferentes modelos de instrução, das principais características e dos procedimentos para o desenvolvimento dos conteúdos, permite que o professor faça uma escolha consciente sobre o modelo de instrução mais adequado para o atendimento das necessidades dos alunos ou atletas, conforme o momento pedagógico que estão experimentando.

Metzler (2011) define modelo de instrução como um plano coerente, que estabelece as diretrizes e os procedimentos para que o professor de educação física possa desenvolver adequadamente o processo de ensino-aprendizagem. A escolha de determinado modelo de instrução por parte do professor de educação física deve considerar o contexto em que esse modelo ou modelos será aplicado. Um dos fatores determinantes para a eficácia do ensino é o nível de conhecimento e de domínio que o professor tem sobre o modelo ou modelos de instrução selecionados. Por fim, Metzler (2011) ressalta as vantagens da utilização dos modelos de instrução para o adequado desenvolvimento de processos de ensino-aprendizagem dos esportes tanto no contexto escolar quanto fora dele. $\mathrm{O}$ processo de ensino-aprendizagem mediante modelos de instrução 
permite que o professor siga um plano geral para direcionamento dos objetivos, metas e estratégias de ensino e contribui para o desenvolvimento cognitivo, psicomotor e afetivo do aluno. Além disso, os modelos de instrução apoiam-se em evidências científicas e possibilitam a mensuração do nível de aprendizagem dos alunos.

No que se refere às teorias de aprendizagem que sustentam os diferentes modelos de instrução, Pérez-Gómez (2007) as agrupa em dois grandes grupos. O primeiro compõe-se das teorias associacionistas, de condicionamento e de estímulo-resposta, em que se distinguem a corrente do condicionamento clássico e a do instrumental ou operante. $\mathrm{O}$ segundo grupo compreende as teorias mediacionais, representado pelas correntes da aprendizagem social e condicionamento por imitação de modelos, as teorias cognitivas e as teorias de processamento de informação. Na perspectiva das teorias mediacionais, Pérez-Gómez (2007) destaca a teoria da gestalt, psicologia genético-cognitiva, psicologia genético-dialética e de processamento de informação, em virtude dos aportes que cada uma delas fez para a construção de uma teoria geral da pedagogia.

Com base nessa classificação, é preciso compreender que as teorias associacionistas, de condicionamento e de estímulo-resposta consideram a aprendizagem um processo cego e mecânico de associação de estímulos e respostas determinado pelas condições externas. Explicam-se a influência das contingências externas sobre a conduta observável e sua manipulação para produzir os comportamentos desejados, desconhecendo a dinâmica interna do indivíduo que pretende aprender. No que tange às teorias mediacionais, entende-se a aprendizagem como um processo de conhecimento e compreensão de relações nas quais as condições externas atuam mediadas pelas condições internas, isto é, a subjetividade cumpre um papel essencial para a aquisição do conhecimento (PÉrEZ-Gómez, 2007).

As teorias cognitivas gradativamente foram percebendo a importância de considerar o ser humano em sua relação com o ambiente. Estudos de Gibson $(1966,1979)$ sobre a psicologia ecológica possibilitaram identificar uma estreita relação indivíduo-ambiente por meio da percepção, porém sem criar uma representação mental do objeto. Além da psicologia ecológica, o surgimento da teoria da ação (NiTsCH, 2009) possibilitou estabelecer uma relação na qual o processo de aprendizagem no indivíduo é resultado da interação entre a pessoa, o ambiente e a tarefa. 
Evidencia-se na prática metodológica da educação física e do esporte a aplicação dos princípios inerentes às teorias de aprendizagem associacionista, da gestalt, de processamento de informação e cognitivas. Na perspectiva da teoria associacionista, derivam-se os modelos de instrução direta, no contexto da teoria da gestalt, especificamente nos jogos esportivos coletivos, nos quais se destaca a utilização do princípio de confronto direto, analítico-sintético e global funcional (Greco, 2001).

Outra obra marcante é a proposta desenvolvida por Bayer (1986), La enseñanza de los juegos deportivos colectivos, em que o autor apresenta uma reorganização do processo de ensino-aprendizagem para os jogos esportivos coletivos, fundamentado na teoria global funcional e pelos elementos comuns nessas modalidades esportivas (bola, adversário, campo de jogo, árbitro, entre outros).

No que se refere às teorias cognitivas, destacam-se duas propostas apoiadas em processos de ensino formal e de aprendizagem incidental. Na proposta de Bunker e Thorpe (1982) e de Thorpe, Bunker e Almond (1986), denominada Teaching Games for Understanding (TGfU), bem como a formulada por Griffin, Mitchell e Oslin (1997), denominada Tactical Awareness Approach (TAA), observam-se características de ensino e aprendizagem intencional. A corrente de aplicação da aprendizagem incidental inicia-se com os trabalhos do grupo da Universidade de Heidelberg e materializam-se na proposta da denominada Escola da Bola (KRÖGER; Roth, 2002).

Por sua vez, na Universidade Federal de Minas Gerais (UFMG) concretiza-se a proposta da Iniciação Esportiva Universal, formulada pelo Grupo de Estudos em Cognição e Ação, sob a coordenação dos professores Greco e Benda (1998), na qual se prioriza o resgate do desenvolvimento das capacidades táticas, bem como uma sistematização do processo de aprendizagem motora mediante o desenvolvimento das capacidades coordenativas. Na proposta são enfatizadas as atividades que resgatam as brincadeiras de rua, os jogos populares como forma de oportunizar comportamentos criativos.

Os jogos esportivos coletivos, a exemplo de basquetebol, futebol, futebol americano, futsal, handebol, rugby, voleibol, entre outros, são atividades que contribuem para o processo de socialização, de construção de identidade e para as relações sociais permeadas pelas condições de gênero, idade, etnia e cultura e nível socioeconômico de crianças, adolescentes, jovens e adultos (GraçA, 2013). Nessa perspectiva, torna-se 
relevante que o professor de educação física direcione o processo de ensino-aprendizagem dessas modalidades por meio da utilização de modelos de instrução que contribuam para a construção do conhecimento tático (declarativo e processual) ${ }^{2}$, assim como para a formação multidimensional do ser humano. Portanto, nas duas próximas seções apresentaremos uma breve descrição do modelo de instrução apoiado na aprendizagem explícita, ou seja, o TGfU (Bunker; Thorpe, 1982; Thorpe; Bunker; Almond, 1986). Na perspectiva da aprendizagem implícita, abordaremos a proposta da Escola da Bola (KRÖGER; Roth, 2002) e da Iniciação Esportiva Universal (Greco; BendA, 1998).

Considerando que o modelo de TGfU estabeleceu as bases conceituais e metodológicas da abordagem centrada no aluno e na compreensão da lógica do jogo (Mesquita, 2013), entendemos ser pertinente apresentar uma breve descrição dessa proposta e, assim, reconhecermos o seu aporte para a pedagogia do esporte. Por fim, entendemos que tanto a proposta de Iniciação Esportiva Universal quanto a da Escola da Bola apresentam-se como uma alternativa viável para a iniciação esportiva aos jogos esportivos coletivos evitando a especialização precoce (Greco et al., 2015a). Por esse motivo, consideramos oportuno apresentar de forma breve cada uma dessas propostas metodológicas no intuito de oferecer uma alternativa para o ensino-aprendizagem dos esportes dentro e fora da escola, especificamente no contexto recreativo e do lazer. Objetivamos, assim, apresentar alternativas metodológicas que visem ao desenvolvimento das capacidades, habilidades e competências do praticante.

2 O conhecimento tático declarativo no esporte refere-se ao conhecimento de regras, funções dos jogadores, estratégias ofensivas e defensivas básicas e compreensão da lógica tático-técnica do jogo (saber o que fazer) (Thomas; French; Humphries, 1986). O conhecimento tático processual refere-se ao desempenho e criação de movimentos (técnicas) para saber o que e quando fazer, selecionando as ações mais adequadas de acordo com diferentes situações de competição (French; Thomas, 1987). Entende-se o conhecimento tático como um sistema complexo de produção sobre a situação atual e eventos passados (conhecimento tático declarativo), combinado com a habilidade de aprendizado do jogador durante o processo de aquisição da técnica (conhecimento processual) (Thomas; French; Humphries, 1986). 


\section{Ensino dos jogos para a compreensão}

O modelo TGfU, traduzido para o português como "Ensino dos Jogos para a Compreensão" (BUNKer; THORPE, 1982; THORPE; BUNKER; Almond, 1986), surge como resposta ao ensino tradicional dos jogos esportivos coletivos, em que a atenção estava direcionada para o desenvolvimento das habilidades básicas do jogo e para o ensino das técnicas isoladas. Basicamente, o TGfU procura o desenvolvimento da capacidade de jogo por meio da compreensão da lógica tática da modalidade esportiva em questão. Trata-se de oferecer o jogo como um momento para a resolução de problemas, e não como um meio para a aplicação de técnicas, em que o aluno é o centro do processo de ensino-aprendizagem e ator fundamental para a construção do seu próprio conhecimento. Isto é, apresenta-se um processo de ensino-aprendizagem pela descoberta guiada e dando preferência ao desenvolvimento do conhecimento declarativo (Graça; Mesquita, 2007; Thorpe; Bunker; Almond, 1986).

O TGfU considera em sua estrutura didática o oferecimento de formas de jogo adaptadas conforme o nível de compreensão e capacidade de intervenção dos alunos na partida. Essas formas de jogo adaptadas são concebidas considerando quatro princípios pedagógicos referentes à modalidade esportiva, da sua modificação por representação (formas de jogo reduzidas representativas das formas adultas do mesmo jogo), modificação por exagero (manipulação das regras de jogo, do espaço e do tempo no intuito de que os alunos se defrontem com determinados problemas táticos) e ajuste da complexidade tática (adaptação dos problemas táticos para provocar no aluno a capacidade de compreender e atuar no jogo) (GraÇA; Mesquita, 2007).

$\mathrm{O}$ jogo adaptado apresenta-se como ponto de partida e fator determinante que condiciona as atividades propostas na aula e as intervenções do professor. Nesse sentido, o modelo apresenta seis fases cíclicas que se concretizam por meio do jogo ou forma de jogo, apreciação do jogo, consciência tática, tomada de decisão, execução motora e desempenho (Bunker; Thorpe, 1982; Thorpe; Bunker; Almond, 1986). A forma de jogo selecionada deve respeitar a idade e a experiência dos alunos, além de considerar o espaço, o número de participantes e material esportivo disponível. Procura-se planejar cuidadosamente os problemas do jogo levando em consideração as possiblidades de finalização ou de 
atacar o alvo quando o espaço é negado pela defesa ${ }^{3}$. A apreciação do jogo refere-se à compreensão de suas regras, e as diferentes alterações ou ajustes nas regras determinarão o repertório das habilidades requeridas e as táticas a serem empregadas. A consciência tática possibilita o conhecimento dos procedimentos táticos utilizados no momento de criar ou negar espaços no ataque e na defesa. A tomada de decisão possibilita a identificação de "o que fazer" e "como fazer" nas diferentes situações-problema do jogo. Isto é, o aluno, por meio da atenção e da percepção, identifica os sinais relevantes ou pistas que auxiliam no processo de tomada de decisão (o que fazer). A partir da identificação do problema tático e da tomada de decisão mais adequada, procede-se a seleção da técnica mais adequada (como fazer). A execução motora refere-se à análise dos elementos constitutivos da técnica que permitem a adequada realização do gesto técnico, isto é, propiciar o entendimento da aplicação da técnica no contexto do jogo. Por fim, o desempenho apresenta-se como a fase em que o professor consegue avaliar o alcance dos objetivos propostos mediante a realização das fases anteriores.

Conforme exposto, o TGfU é um modelo que, por suas características e procedimentos pedagógicos e metodológicos, permite o ensino do esporte e em especial dos jogos esportivos coletivos tanto no ambiente escolar quanto fora dele. Possibilita ainda a abordagem do esporte em quaisquer de suas manifestações, ou seja, escolar, recreação, saúde, reabilitação, rendimento, profissional ou alto nível de rendimento.

\section{Modelos de ensino-aprendizagem incidentais}

O modelo de Iniciação Esportiva Universal (Greco; BendA, 1998) e de Escola da Bola (Kröger; Roth, 2002) se apoiam na aprendizagem implícita (Reber, 1989). O modelo de Escola da Bola surgiu na Alemanha com o objetivo de ofertar um processo de ensino-aprendizagem dos esportes para crianças de até 10 anos (KRÖGER; Roth, 2002; Roth; KRÖGER; Memmert, 2017; Roth; Memmert; Schubert, 2016). No que se refere ao modelo de Iniciação Esportiva Universal, constata-se na literatura

3 Essa proposta pode ser utilizada, por exemplo, para esportes coletivos de invasão (basquetebol, futsal, futebol, handebol etc.), rebatida (beisebol, cricket), rede (voleibol), raquete (tênis, tênis de mesa, badminton), parede (squash), entre outros. Por esse motivo, o modelo aborda princípios gerais no intuito de possibilitar a aquisição do conhecimento tático e habilidades esportivas (técnica). 
vários ensaios no intuito de apresentar e divulgar a proposta como uma opção metodológica viável que contribui para o adequado processo de iniciação esportiva nos jogos esportivos coletivos no Brasil (GRECo et al., 2015a; Greco; Benda, 1998; Greco; Silva; Santos, 2009).

O modelo da Escola da Bola apoia-se em três pilares básicos denominados de A, B e C, ou seja, capacidades táticas (A), capacidades coordenativas (B) e habilidades técnicas ou famílias de habilidades esportivas $(\mathrm{C})$. Desse modo, apresenta-se um ABC para iniciantes nos jogos em que as crianças, em primeiro lugar, aprendem a jogar com liberdade, reconhecer e perceber situações de forma adequada e compreendê-las na perspectiva tática (KRÖGER; RoTH, 2002).

O desenvolvimento do ABC segue uma série de princípios pedagógicos, quais sejam: do geral ao específico, do desenvolvimento adequado às idades, do desenvolvimento das competências táticas básicas (inteligência de jogo e criatividade), de jogar ao jogar e exercitar, da aprendizagem implícita à explícita (Greco, 2013).

No que se refere ao modelo de Iniciação Esportiva Universal, o jogar para aprender e aprender jogando favorece a construção da biografia de movimento da criança por meio da aquisição de experiências de jogo, em primeiro lugar de forma implícita (jogar para aprender) e posteriormente de forma explícita (aprender jogando). Contudo, ressaltamos que tanto o jogo quanto o processo de treinamento da coordenação continuam a ser desenvolvidos nessa fase de aprendizagem explícita (GRECO, 2013; Greco; Benda, 1998).

Importante saber que os conteúdos ofertados no modelo de Iniciação Esportiva Universal priorizam as formas de aprendizado implícito, entretanto o professor deve estruturar os conteúdos de forma explícita. Nesse sentido, demanda-se do professor planejamento, sistematização, avaliação e ajuste constante do processo de ensino-aprendizagem (Greco, 2013).

No que se refere aos conteúdos, o modelo de Iniciação Esportiva Universal caracteriza-se pelo equilíbrio entre o desenvolvimento dos processos de aprendizagem tática e da aprendizagem motora, os quais se relacionam por meio da oferta dos denominados jogos de inteligência e criatividade tática. Nessa perspectiva, sugere-se que a estruturação das aulas e dos processos de ensino-aprendizagem apresentem primeiramente atividades referentes à aprendizagem tática antes da aprendizagem motora. Trata-se de priorizar o jogo antes dos exercícios direcionados 
relacionados com o desenvolvimento das capacidades coordenativas e habilidades técnicas ou famílias de habilidades (Greco, 2013).

No aporte de Greco et al. (2015a), postula-se a integração dos modelos de Iniciação Esportiva Universal e Escola da Bola como alternativa pedagógica para a formação em longo prazo. Essa afirmação justificase pelos aspectos comuns que ambos os modelos apresentam na perspectiva do conceito da aprendizagem implícita e do ABC de princípios pedagógicos que as duas propostas compartilham. Esses princípios são:

- jogar para aprender e aprender jogando;

- oportunizar ambientes criativos de experimentação motora;

- jogo como exercício e exercício como jogo.

Ressalta-se que a proposta de integração de ambos os modelos objetiva a proposição de uma referência de ensino-aprendizagem que ofereça a oportunidade de desenvolver capacidades, habilidades e competências para todas as crianças e iniciantes nos esportes, em especial nos jogos esportivos coletivos.

Para tal, Greco et al. (2015a) reforçam o conceito do ABC referente às três estruturas do processo pedagógico de desenvolvimento das capacidades, habilidades e competências em longo prazo, isto é: estrutura substantiva (A), estrutura metodológica (B) e estrutura temporal (C). A estrutura substantiva refere-se ao processo de desenvolvimento das capacidades táticas e coordenativas inerentes à realização das ações esportivas, das habilidades técnicas ou famílias de habilidades que emergem como requisitos prévios para a futura aquisição da técnica de determinada modalidade esportiva e, por fim, ao desenvolvimento das competências, ou seja, do saber o que fazer e como fazer. A estrutura metodológica corresponde ao processo de aprendizagem tática por meio do jogo (saber o que fazer), ao processo de aprendizagem motora por meio do desenvolvimento das capacidades coordenativas e famílias de habilidades (Figura 1). Nessa estrutura também se apresenta o treinamento tático-técnico, isto é, o processo de consolidação do processo em longo prazo visando à prática de uma modalidade esportiva específica. Por fim, na estrutura temporal apresenta-se a definição de três estágios que determinam o processo de ensino-aprendizagem em longo prazo: estágios de formação, transição/fixação e decisão. 
A proposta de integração entre o modelo Iniciação Esportiva Universal e Escola da Bola consolida-se pela estrutura de alfabetização esportiva ou um ABC da Iniciação Esportiva Universal (Greco et al., 2015a). Nessa perspectiva, o “A” corresponde aos conteúdos que estabelecem o percurso que o aprendiz faz da aprendizagem tática ao treinamento tático-técnico; o "B" refere aos conteúdos que estabelecem o percurso que se inicia na aprendizagem motora e vai até o treinamento tático-técnico; e o "C" estabelece o processo de treinamento tático-técnico. Por fim, os denominados jogos de inteligência e criatividade tática são conteúdos que se apresentam em cada um dos elementos constitutivos do ABC da alfabetização esportiva. A principal função dos jogos de inteligência e criatividade tática é relacionar e contribuir para o desenvolvimento dos conteúdos próprios do $\mathrm{ABC}$. Trata-se de jogos tradicionais ou da cultura popular brasileira que possibilitam a vivência de diversas exigências táticas e motoras que consolidam o processo de ensino-aprendizagem em longo prazo. Estimula-se com a prática dos jogos de inteligência e criatividade tática as formas de pensamento convergente e divergentes, atenção, percepção e tomada de decisão, por meio da utilização das habilidades motoras básicas.

Cada uma das supracitadas estruturas (ABC da Iniciação Esportiva Universal) apresenta conteúdos específicos e que se apresentam na Figura 1. A estrutura denominada "A", da aprendizagem tática ao treinamento tático-técnico, oferta um conjunto de jogos orientados para o desenvolvimento das capacidades táticas básicas propostas por Kröger e Roth (2002):

- acertar o alvo;

- transportar a bola para o objetivo;

- jogar coletivamente ou jogar em conjunto;

- reconhecer os espaços;

- oferecer-se;

- $\quad$ orientar-se (sair da marcação);

- criar superioridade numérica; e

- $\quad$ superar a ação do adversário.

Objetiva-se assim a compreensão da lógica dos jogos esportivos coletivos, por meio da oferta de jogos orientados para cada um desses parâmetros táticos. Outro conteúdo que faz parte do "A" são as denominadas 
estruturas funcionais gerais e direcionadas. As estruturas funcionais gerais objetivam a aprendizagem de comportamentos táticos comuns aos jogos esportivos coletivos, sem a intenção de abordar uma modalidade esportiva específica. Portanto, oferecem-se jogos em diferentes configurações, isto é, superioridade numérica $(2 \times 1)$, utilização do curinga $(1 \times 1+1,2 \times 2+1,3 \times 3+1)$ e igualdade numérica $(2 \times 2,3 \times 3,4 \times 4)$. Nas estruturas funcionais direcionadas objetiva-se a abordagem de um jogo esportivo coletivo específico, a exemplo de basquetebol, futebol, futsal, handebol, hóquei, rugby, voleibol, entre outros. Procura-se a aprendizagem de comportamentos táticos individuais e de grupo específicos da modalidade esportiva em questão, porém mantendo as configurações referentes à proposição de jogos em superioridade numérica, ação do curinga (+1) e igualdade numérica (Greco, 2013; Greco et al., 2015a; Greco; BendA, 1998).

Continuando com o ABC da Iniciação Esportiva Universal, os conteúdos propostos para a estrutura " $\mathrm{B}$ ", da aprendizagem motora ao treinamento tático-técnico, apoiam-se em dois conteúdos:

1. capacidades coordenativas e

2. famílias de habilidades esportivas.

No que se refere às capacidades coordenativas, o seu processo de desenvolvimento perpassa pela oferta inicialmente de exercícios e depois de formas jogadas. A fórmula proposta para o desenvolvimento da coordenação motora estabelece a utilização de habilidades simples (por exemplo, correr, saltar, lançar, empurrar etc.), mais exigências aferentes (recepção de informação visual, auditiva, tátil, sinestésica e vestibular) e, por fim, acrescentar os condicionantes da motricidade:

- $\quad$ pressão de tempo;

- precisão;

- $\quad$ organização ou simultaneidade;

- complexidade ou sequência;

- carga; e

- $\quad$ variabilidade.

Recomenda-se a maior variabilidade possível de movimentos e utilização de materiais (bola, bastão, bambolê, patins, entre outros) na 
realização dos exercícios e formas jogadas. Realizar o mesmo exercício com mãos, pés, raquetes ou bastões. Por fim, a sequência sugerida é de se apresentarem exercícios inicialmente com a utilização de um elemento, depois com dois elementos até chegar à utilização de três elementos. Os exercícios devem permitir a interação com o colega, ou seja, coordenar com o outro (GRECO, 2013).

As famílias de habilidades esportivas apresentam-se como um conjunto de habilidades necessárias à realização de técnicas. Trata-se de ofertar atividades em que o aprendiz experimenta movimentos ou famílias de movimentos que se aproximam das técnicas específicas dos esportes. Essas habilidades, conforme Kröger e Roth (2002), são:

- $\quad$ organização dos ângulos;

- controle (regulação) da força;

- determinar o tempo de passe e da bola;

- determinar linhas de corrida e tempo da bola;

- $\quad$ preparar-se para a realização da ação;

- $\quad$ antecipar a direção e a distância do passe;

- $\quad$ antecipação da posição defensiva; e

- observar deslocamentos.

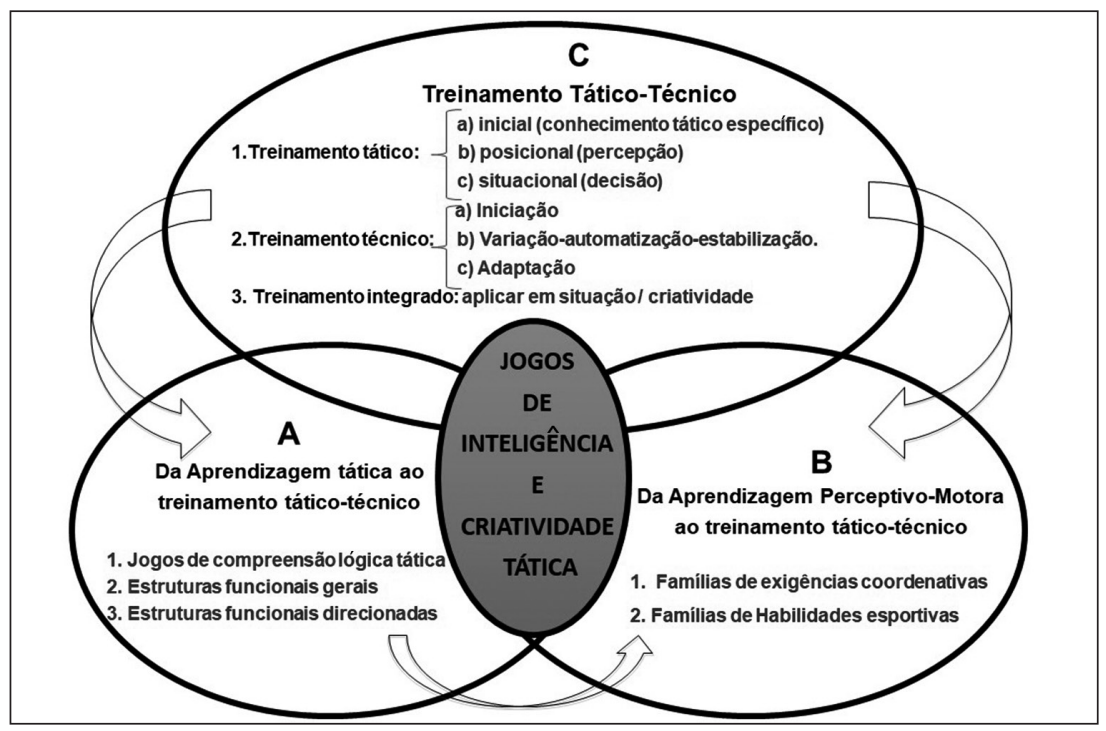

Figura 1 - A estrutura metodológica da Iniciação Esportiva Universal.

Fonte: Greco et al. (2015a, p. 343). 
A estrutura referente ao treinamento tático-técnico "C" apresentase como um modelo pendular para o planejamento e a sistematização desse conteúdo. Nesse sentido, o treinamento tático decorre em três momentos denominados de tático-coordenativo, tomada de decisão e tático-técnico. O treinamento técnico também apresenta três momentos: automatização, estabilização da técnica e variação. Tanto no treinamento tático quanto no treinamento técnico a atenção cumpre um papel fundamental ao se requisitar seu desvio no momento tático-coordenativo e tático-técnico no treinamento tático, bem como no momento de automatização e variação no treinamento técnico. Ao mesmo tempo, requisita-se a focalização da atenção no momento da tomada de decisão (treinamento tático) e de estabilização (treinamento técnico). Sugere-se que o treinamento tático-técnico se inicie a partir da fase de direção (14 a 16 anos), conforme os preceitos do sistema de formação e treinamento esportivo (Greco et al., 2015b; Greco; BendA, 1998).

A proposta de Iniciação Esportiva Universal e Escola da Bola são modelos de ensino-aprendizagem que contribuem para a formação multidimensional do ser humano. Trata-se de oferecer conteúdos que permitam o desenvolvimento das capacidades, habilidades e competências do aprendiz. Por meio do jogo e dos exercícios ou formas jogadas propostos nos modelos de Iniciação Esportiva Universal e Escola da Bola é possível atender aos objetivos específicos da dimensão atitudinal, procedimental e conceitual na formação do ser humano. Pretende-se com isso estabelecer uma cultura do esporte que ofereça as mesmas oportunidades para todos e a possibilidade de praticar o esporte em todas as suas manifestações, isto é, como meio para o lazer, saúde, reabilitação, formação, profissional, rendimento e alto nível de rendimento.

\section{Implicações para a prática}

Nessa parte do texto serão apresentados alguns exemplos de atividades que podem compor o repertório a ser utilizado em projetos sociais de esporte. Mesmo ainda muito distantes do esporte formal, trata-se de brincadeiras e jogos que estimulam o desenvolvimento de habilidades importantes para a prática das modalidades esportivas. As cinco primeiras atividades apresentadas estimulam o desenvolvimento do controle de corpo em deslocamentos, necessário para a prática de toda modalidade esportiva. Por meio de brincadeiras populares são estimuladas as ações de: sair rápido, parar bruscamente e/ou mudar de direção. Além disso, o 
professor/técnico pode inserir o elemento drible (quicar uma bola) nas atividades. Já a atividade 6 é um exercício de passe.

\section{Atividades}

1. Nunca três: o grupo de alunos é dividido em duplas de mãos dadas, paradas, espalhadas pelo espaço disponível para a atividade. Dois alunos ficam sem formar dupla, e um deles será o pegador e o outro o fugitivo. Quando o aluno que está fugindo segura a mão de alguém que está em dupla, o aluno da ponta deixa o trio (nunca três) e passa a fugir. Posteriormente, pode-se usar a variação de quem sai do trio passa a pegar, e quem estava pegando passa a correr.

2. Salve-se com um abraço: pega-pega no qual o pique é estar abraçado a um colega.

3. Amigo, amigo da onça: pega-pega no qual o pique é estar abraçado a um colega (amigo); porém, se um aluno abraça alguém que já está abraçado, ele é amigo do mais próximo (aquele que foi abraçado) e amigo da onça do mais distante (aquele que não foi abraçado), que perde o pique e deve sair correndo para não ser pego.

4. Canavial (Rua e Avenida): os alunos estão dispostos em filas de mãos dadas e braços esticados, formando uma barreira; combina-se a posição dos alunos conforme o comando do professor (exemplo: quando o professor disser "rua", os alunos ficam de frente para ele; quando o professor disser "avenida”, os alunos ficam de lado com o ombro direito na direção do professor, sempre formando a barreira). Assim, os alunos criam corredores entre si, nos quais irão passar um ou mais alunos pegando e um fugindo, não podendo quebrar a barreira. Variação: o próprio aluno que está fugindo dá o comando de "rua" ou "avenida".

5. Pega-pega no círculo: Os alunos são dispostos em um círculo voltados para o seu interior, e dentro dele haverá um pegador e um fugitivo. O pegador deve encostar a mão no fugitivo antes que ele troque de posição com alguém que está parado no círculo. Se isso não acontecer, quem estava no círculo e trocou de posição passa a ser o fugitivo. Variações: quem estava no círculo passa a ser o pegador; ter mais de um fugitivo e de um 
pegador (nesse caso, eles devem ser identificados por pares de camisas com cores diferentes).

Observação: todas as atividades descritas ( 1 a 5 ) podem ter a variação de incluir o uso de bolas. Assim os alunos (pegadores e fugitivos) se deslocam driblando ou conduzindo a bola.

6. 3x2 (passes): cinco alunos são distribuídos em um espaço delimitado. Três são atacantes e dois, defensores. O jogo resume-se à troca de passes. Quem ataca fica parado; quem marca deve encostar a mão em um jogador quando este está com a posse de bola. Quando isso acontecer, os jogadores trocam de posição. Variação: 4x3, 5x4.

A seguir serão apresentadas sugestões de atividades para o processo de ensino-aprendizagem dos jogos esportivos coletivos, estruturadas conforme as diretrizes do modelo de ensino-aprendizagem de Iniciação Esportiva Universal (Greco; Benda, 1998) e Escola da Bola (Kröger; Roth, 2002). Todas as atividades foram adaptadas do Manual de práticas para a iniciação esportiva no Programa Segundo Tempo (Greco; Conti; PÉrez-Morales, 2013). As atividades descritas a seguir referem-se aos denominados jogos de inteligência e criatividade tática e estruturas funcionais gerais. Entendemos que essas atividades podem ser aplicadas no contexto do esporte recreativo e inclusivo.

Todas as atividades sugeridas neste apartado deverão ser realizadas fazendo uso das mãos, dos pés e do bastão e seu intuito é contribuir para o entendimento da lógica tática dos jogos coletivos de invasão pela realização dos jogos de inteligência e criatividade tática e das estruturas funcionais. A utilização de mãos, pés e bastão em cada um dos jogos propostos possibilita o desenvolvimento da percepção e da atenção, bem como o desenvolvimento das capacidades coordenativas e habilidades motoras básicas.

\section{Jogos de inteligência e criatividade tática}

Nome: Gol na faixa

Número de Participantes/Material: mínimo de 8 participantes; 1 bola, pratos demarcatórios e coletes.

Descrição: em um campo de 30m x 15m (o tamanho do campo pode ser proporcional ao espaço com que o professor conta e o número de alunos), duas equipes procuram ter a posse de 
bola. Cada equipe deve defender um setor de 3 metros de largura, que está localizado no fundo da quadra e fora do campo no qual disputam a posse de bola. O objetivo é fazer com que um companheiro de equipe receba a bola dentro da faixa defendida pela equipe adversária, obtendo-se assim um ponto.

Desenho:

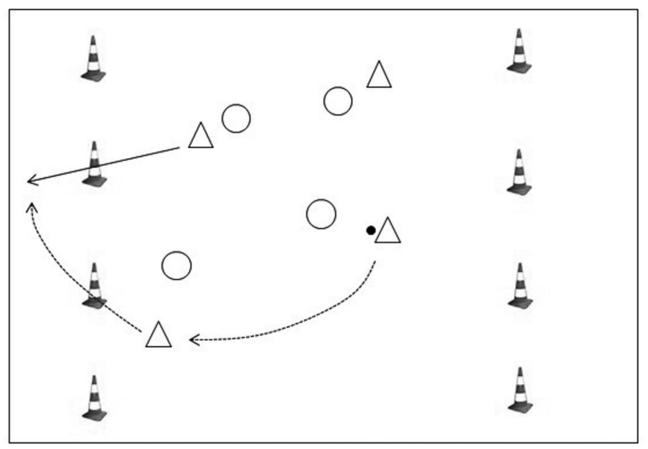

Variações conforme a faixa etária:

8-10 anos: incluir um curinga $(+1)$ no ataque para cada time. $\mathrm{O}$ jogo será na configuração de $4 \times 4+1$. Cada curinga deverá estar posicionado em uma das linhas laterais do campo. $\mathrm{O}$ curinga não poderá marcar o ponto, isto é, dar o passe para o colega de time que está posicionado na faixa para receber o passe. Para marcar o ponto, o curinga deverá ser acionado pelo menos uma vez. O curinga deverá atuar apenas no ataque e se deslocará apenas pela linha lateral, ou seja, não poderá entrar no campo de jogo.

10-12 anos: limitar o número de toques na bola por participante (2-3 toques). Recomendar a marcação individual. Utilizar o curinga $(+1)$ dentro do campo.

13-14 anos: estabelecer um tempo limite (3 segundos) para permanência do participante dentro das faixas no fundo do campo; 15-16 anos: o participante que receber a bola na faixa no fundo do campo deve conseguir devolvê-la para um colega fora 
do setor para obter o ponto. Fixar um participante em cada setor no fundo do campo, sendo que eles só podem dar um toque na bola.

Nome: Quatro gols

Número de participantes/Material: mínimo de 8 participantes; 1 bola, 8 cones, pratos demarcatórios e coletes.

Descrição: em um campo de jogo se posicionam 4 gols espalhados de maneira que não fiquem um perto do outro. Duas equipes de 4 participantes cada uma disputam a posse de bola. A equipe no ataque, isto é, com a posse de bola, deve realizar um passe por entre os gols que estão posicionados no campo de jogo. No momento do passe, um colega de time deverá posicionar-se por trás do gol para receber o passe e dessa maneira marcar o ponto.

Desenho:

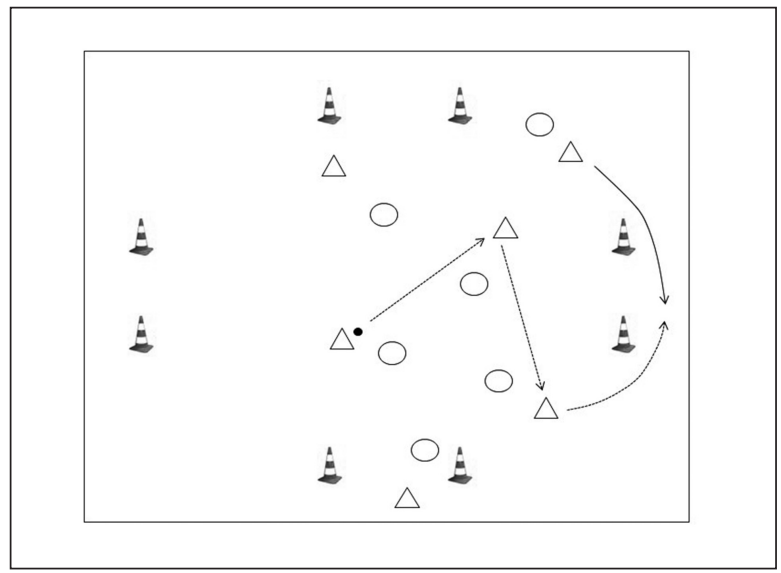

Variações conforme a faixa etária:

8-10 anos: incluir um curinga $(+1)$ no ataque para cada time. O jogo será na configuração de $6 \times 6+1$. O curinga ajudará na troca de passes do time no ataque, sendo que não poderá marcar o ponto. Para marcar o ponto, o time no ataque deverá acionar o curinga, isto é, dar o passe para ele, pelo menos uma vez. O curinga ajudará os dois times no ataque. 
10-12 anos: manter o curinga e proibir a marcação de dois gols consecutivos no mesmo gol.

13-14 anos: numerar os gols, ficando uma equipe com os gols "pares" e a outra com os gols "ímpares".

15-16 anos: alternar o número de toques permitidos na bola por participante a cada 2 passes (toques livres, toque de primeira, toques livres, toque de primeira e assim sucessivamente).

Outras variações ou sugestões: para se jogar com a mão, o ponto deverá ser marcado se o passe for realizado no meio dos gols, isto é, o passador deverá estar de um lado do gol e o receptor do lado contrário. Para marcar o ponto, o receptor terá que dominar a bola. Para se jogar com o bastão, utiliza-se o mesmo procedimento do jogo com o pé.

\section{Estruturas funcionais}

Nesta seção será sugerida a organização do espaço e dos alunos de forma que possa possibilitar a vivência das estruturas funcionais gerais valendo-se de várias configurações, ou seja, possibilitar que os alunos joguem desde $1 \times 0$ até $\mathrm{o} 3 \times 3$, transitando pelas várias possibilidades táticas que só as estruturas funcionais oferecem.

A atividade a seguir foi pensada para uma turma de 40 alunos com idade entre 10 e 12 anos de diferentes níveis de habilidade e experiência nos jogos esportivos coletivos de invasão. Em primeiro lugar, organiza-se a turma em grupos de 6 componentes, ou seja, para uma turma de 42 alunos teremos 7 grupos de 6 componentes. Divide-se a quadra de forma que seja possível estabelecer várias quadras de diferentes tamanhos (Figura 2). Conforme coloca Greco (2013), é importante que durante a realização das estruturas funcionais o professor planeje as variações referentes ao espaço (variar o tamanho da quadra), tempo (diminuir ou aumentar o tempo de duração do jogo), regras (mudar a forma de pontuar ou limitar as ações do atacante ou do defensor), número de jogadores (igualdade numérica, superioridade numérica, inferioridade numérica e curinga), técnica (estabelecer o tipo de técnica utilizada para o passe, a condução, a finalização, entre outras), tática (realizar tabelas, cruzamentos, ponte aérea, jogo na largura ou profundidade) e número 
de decisões (aumentar o número de alvos, permitir a pontuação em vários alvos ao mesmo tempo, entre outras alternativas).

A configuração recomendada para a realização das estruturas funcionais é de $3 \times 3$. Essa configuração possibilita a realização de outras configurações e proposição de diferentes objetivos táticos, por exemplo: em um dos espaços destinados para a realização das estruturas funcionais, os alunos podem jogar futsal na configuração $2 \times 2$ com goleiro móvel; em outro espaço, outro grupo poderá jogar voleibol na configuração de 3x3; em outro espaço, será a vez de jogar handebol na configuração de $2 \times 2$ com goleiro fixo. Outro espaço da quadra poderá ser utilizado para jogar basquetebol na configuração de $2 \times 2+1$ com apenas uma tabela. Caso a quadra não conte com as tabelas de basquetebol, sugerimos utilizar a mesma configuração $(2 \times 2+1)$, porém o ponto será marcado quando um dos jogadores no ataque receba o passe do colega de time atrás da linha de fundo que delimita o espaço de jogo.

A Figura 2 apresenta uma sugestão de organização do espaço e dos alunos para a realização das estruturas funcionais.

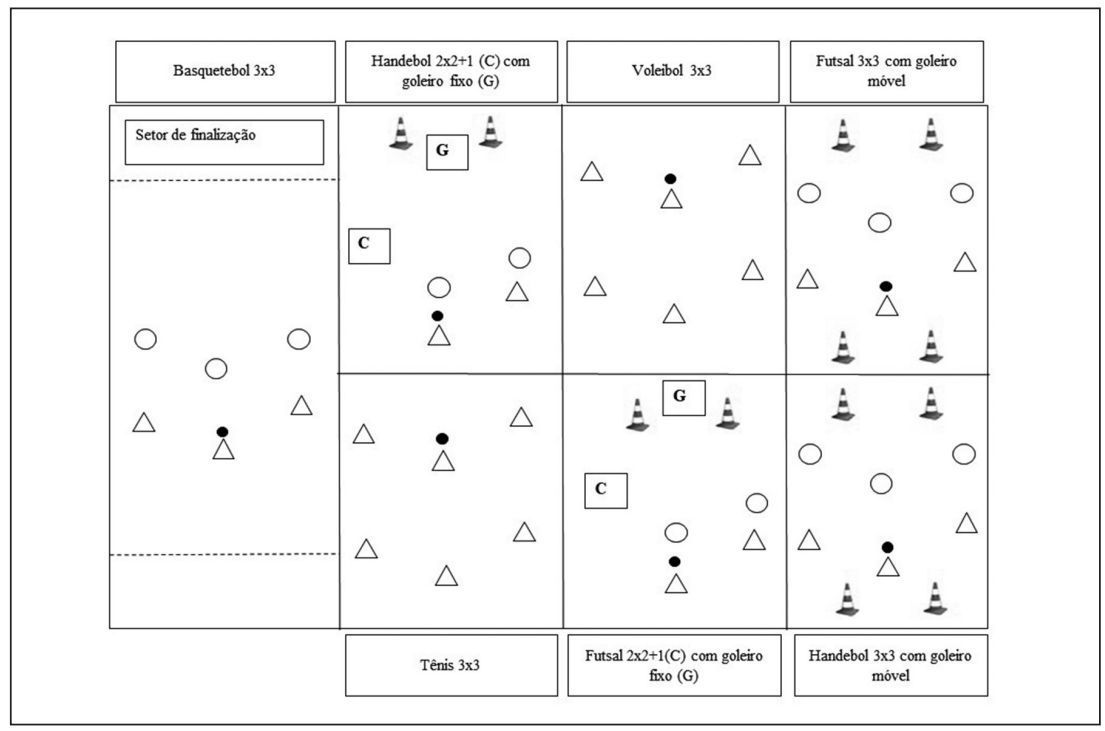

Figura 2 - Organização dos alunos, do espaço e das atividades para realização das estruturas funcionais. 
Na Figura 2 observa-se que o espaço disponível para a aula está dividido em 7 espaços. No caso do espaço para jogar basquetebol, a finalização será pela recepção do passe no denominado setor de finalização. Ressalta-se que a letra " $G$ " refere-se ao goleiro e a letra " $C$ " à curinga $(+1)$. As linhas tracejadas nos espaços estabelecidos para jogar tênis e voleibol correspondem à rede, que para esse caso poderá ser substituída por um elástico ou fileiras de cones maiores dispostos em linhas retas. O professor poderá estabelecer uma duração de 5 a 10 minutos para todos os jogos. Após a finalização do jogo, o professor solicitará que apenas 3 jogadores se desloquem para a quadra à esquerda mais próxima. Espera-se que com esse sistema de rodízio os jogadores realizem confrontos com trios diferentes, o que permite maior variabilidade nas situações do jogo.

\section{Referências}

Barbanti, V. J. Dicionário de educação física e esporte. São Paulo: Manole, 2003.

BAyer, C. La enseñanza de los juegos deportivos colectivos. Barcelona: Hispano-Europea, 1986.

Belbenoit, G. O desporto na escola. Lisboa: Estampa, 1976.

Bracht, V. Esporte-Estado-Sociedade. Revista Brasileira de Ciências do Esporte, Porto Alegre, v. 10, n. 2, p. 69-73, jan. 1989.

BRASIL. Lei n. 9.615, de 24 de março de 1998. Institui normas gerais sobre desporto e dá outras providências. Diário Oficial da União, Brasília, DF, 25 mar. 1998.

Bunker, D. J.; Thorpe, R. D. A model for the teaching of games in secondary schools. Bulletin of Physical Education, Yorkshire, v. 18, n. 1, p. 5-8, 1982.

Freire, P. R. N. Pedagogia da autonomia: saberes necessários à prática educativa. São Paulo: Editora Paz e Terra, 2005.

French, K.; Thomas, J. The relation of knowledge development to children's basketball performance. Journal of Sport Psychology, Washington, v. 9, p. 15-32, 1987.

Gibson, J. J. The senses considered as perceptual systems. Boston: Houghton Mifflin, 1966.

Gibson, J. J. The ecological approach to visual perception. Boston: Houghton Mifflin, 1979. 
González, F. J. Projeto curricular e educação física: o esporte como conteúdo escolar. In: Rezer, R. (Org.). O fenômeno esportivo: ensaios crítico-reflexivos. Chapecó: Argos, 2006. p. 69-109.

GraçA, A. Os contextos sociais do ensino e aprendizagem dos jogos desportivos coletivos. In: Nascimento, J. V.; Ramos, V.; Tavares, F. (Eds.). Jogos desportivos: formação e investigação. Florianópolis: UDESC, 2013. p. 79-102.

Graça, A.; Mesquita, I. A investigação sobre os modelos de ensino dos jogos desportivos. Revista Portuguesa de Ciências do Desporto, Porto, v. 7, n. 3, p. 401-421, 2007.

Greco, P. J. Métodos de ensino-aprendizagem-treinamento nos jogos esportivos coletivos. In: Silami Garcia, E.; Moreira, K. L. (Eds.). Temas atuais IV. Belo Horizonte: Health, 2001. p. 48-72.

Greco, P. J. Capacidade de jogo e aprendizagem tática nos modelos de ensino-aprendizagem incidental. In: NAscimento, J. V.; Ramos, V.; TaVares, F. (Eds.). Jogos desportivos: formação e investigação. Florianópolis: UDESC, 2013. p. 485-512.

Greco, P. J. et al. Iniciação esportiva universal: o jogo do "ABC” na alfabetização esportiva. In: Lemos, K. L. M.; Greco, P. J.; Pérez-Morales, J. C. (Eds.). In: Congresso Internacional dos Jogos Desportivos, 5., 2015, Belo Horizonte. Anais... Belo Horizonte: EEFFTO/UFMG, 2015 a. p. 335-360.

Greco, P. J. et al. A cognição em ação: proposta de um modelo de treinamento tático- técnico da tomada de decisão nos jogos desportivos coletivos. In: Lemos, K. L. M.; Greco, P. J.; Pérez-Morales, J. C. (Eds.). In: Congresso Internacional dos Jogos Desportivos, 5., 2015, Belo Horizonte. Anais... Belo Horizonte: EEFFTO/UFMG, 2015b. p. 311-334.

Greco, P. J.; Benda, R. N. Iniciação esportiva universal: da aprendizagem motora ao treinamento técnico. Belo Horizonte: UFMG, 1998.

Greco, P. J.; Conti, G.; Pérez-Morales, J. C. Manual de práticas para a iniciação esportiva no Programa Segundo Tempo. Maringá: Editora da Universidade Estadual de Maringá, 2013.

Greco, P. J.; Silva, S. A.; Santos, L. R. Organização e desenvolvimento pedagógico do esporte no programa segundo tempo. In: Oliveira, A. A. B.; Perim, G. L. (Eds.). Fundamentos pedagógicos do Programa Segundo Tempo: da reflexão à prática. Maringá: Editora da Universidade Estadual de Maringá, 2009. p. 163-206. 
Griffin, L. L.; Mitchell, S. A.; Oslin, J. L. Teaching sport concepts and skills: a tactical approach. Londres: Champaign, 1997.

KIRK, D.; MacPhaIL, A. Teaching games for understanding and situated learning: Rethinking the Bunker-Thorpe model. Journal of Teaching in Physical Education, United States, v. 21, p. 177-192, 2002.

KorsaKas, P.; Rose Junior, D. Os encontros e desencontros entre esporte e educação: uma discussão filosófico-pedagógica. Revista Mackenzie de Educação Física e Esporte, v. 1, n. 1, p. 83-93, 2002.

Kröger, C.; Roth, K. Escola da bola: um ABC para iniciantes nos jogos esportivos. São Paulo: Phorte, 2002.

LuCEnA, R. F. O esporte na cidade: aspectos do esforço civilizador brasileiro. Campinas: Autores Associados; CBCE, 2001.

Machado, G. V.; Galatti, L. R.: Paes, R. R. Pedagogia dos esportes e projetos sociais: interlocuções sobre a prática pedagógica. Movimento, Porto Alegre, v. 21, n. 2, p. 405-418, abr./jun. 2015.

Mesquita, I. Perspectiva construtivista da aprendizagem no ensino do jogo. In: Nascimento, J. V.; Ramos, V.; Tavares, F. (Eds.). Jogos desportivos: formação e investigação. Florianópolis: UDESC, 2013. p. 103-132.

Metzler, M. Instructional models for physical education. 3. ed. Scottsdale, AZ: Holcomb Hathaway, 2011.

Nitsch, J. R. Ecological approaches to Sport Activity: a commentary from an action-theoretical point of view. International Journal Sport Psychology, Italy, v. 40, p. 152-176, 2009.

Parlebas, P. Problemas teóricos y crisis actual en la educación física. Lecturas de Educación Física y Deportes, Buenos Aires, ano 2, n. 7, oct. 1997.

Pérez-Gómez, A. I. Os processos de ensino-aprendizagem: análise didática das principais teorias da aprendizagem. In: Gimeno SACRIsTÁn, J.; Pérez-Gómez, A. I. (Eds.). Compreender e transformar o ensino. Porto Alegre: Artmed, 2007. p. 28-52.

Reber, A. S. Implicit learning and tacit knowledge. Journal of Experimental Psychology: General, United States, v. 118, n. 3, p. 219-235, 1989.

Roth, K.; Kröger, C.; Memmert, D. Escola da bola: jogos de rede e raquete. São Paulo: Phorte Editora, 2017.

Roth, K.; Memmert, D.; Schubert, R. Escola da bola: jogos de arremesso. São Paulo: Phorte Editora, 2016.

Thomas, J. R.; French, K. E.; Humphries, C. A. No title. Journal of Sport Psychology, Washington, n. 8, p. 259-272, 1986. 
Thorpe, R. D.; Bunker, D. J.; Almond, L. Rethinking games teaching. Loughborough: UK: University of Technology; Department of Physical Education and Sport Science, 1986. 


\section{CAPÍTULO 9}

\section{AS LUTAS COMO POSSIBILIDADES DE LAZER ${ }^{1}$}

Junior Vagner Pereira da Silva

Rodrigo Barbosa Terra

A articulação dos temas lutas e lazer como objetos de discussão e merecedores de espaço em uma obra sobre o lazer mostra-se oportuna, haja vista que ambos receberam (e por vezes ainda recebem) tratamentos pejorativos por parte de autoridades políticas, refletindo sobremaneira na percepção da população a respeito desses conteúdos e influenciando nas decisões de ocupação do tempo social.

No que se refere ao lazer, por vezes o que predominou no imaginário de parte da sociedade - e não raramente ainda predomina - é que o que dignifica a humanidade não é o lazer, mas sim o trabalho, pois seria nesse tempo social produtivo que o sujeito demonstraria suas virtudes.

Se o trabalho é o que dignifica o homem, por oposição o uso do tempo disponível com experiências de lazer seria perdição, "coisa de vagabundo" e momento em que prospera o profano. Seria o lazer então um tempo de preguiça, improdutivo, desperdiçado, perdido. Por tratar-se de um tempo perdido, logo traria prejuízos ao desenvolvimento de uma sociedade produtiva.

Compreensões como essas se encontram fundamentadas em um modelo de sociedade pretendida, que no Brasil foi delineada com base na percepção médica higienista do início no século $\mathrm{xx}$, que tinha como projeto o controle corporal visando a um indivíduo contido, disciplinado e civilizado. Para lograr êxito nesse projeto, ações de lazer eram tratadas como vadiagem e relacionadas à delinquência, assumidas como criminalidade (MARCASSA, 2002).

1 Este texto compõe parte do material produzido para o curso de Educação a Distância "Formação em programas sociais: PELc e Vida Saudável”, módulo Lutas, Esporte e Lazer. 
É com a disseminação dessa concepção moralizante do lazer que parte da sociedade construiu sua percepção sobre o uso do tempo disponível, fazendo com que, por vezes, não houvesse interesse em se ocupar com experiências de lazer, não lhe atribuindo seu valor real, tampouco creditando valor formativo.

Não diferente foi a visão construída historicamente a respeito das lutas, sobretudo da capoeira, que mesmo sendo originalmente brasileira, no início do século $\mathrm{xx}$ foi inserida no contexto das atividades de controle corporal da população brasileira, obtendo o rótulo de atividade vinculada à malandragem e à vadiagem, estando seus praticantes sob o risco de serem presos (MARCASSA, 2002).

Isso representava não só uma preocupação com os usos "ilícitos" do tempo livre, mas também a intervenção sobre o ócio e a alteração dos hábitos e tipos de divertimentos tradicionais. A ociosidade, entendida como produtora de violência, da criminalidade, da capoeiragem, da vagabundagem, dos vícios, das doenças e das epidemias, seria a principal atividade do cotidiano familiar a ser questionada, enquadrada e combatida [MARCAssa, 2002, p. 64].

Acontecimentos como esses corroboraram historicamente não apenas para a capoeira sofrer estereótipos e preconceitos, mas sim as lutas de maneira geral, pois, por sua dinâmica envolver constante contato físico e suas técnicas e estratégias estarem pautadas no desequilíbrio, na contusão, imobilização e exclusão do oponente de uma área, de forma generalizada lhes foram atribuídas o rótulo de atividades violentas, fazendo com que nem sempre os pais se sintam à vontade em permitir que seus filhos se envolvam com esse tipo de experiência de lazer.

Desde a infância, quando brincadeiras lúdico-agressivas (brincadeiras de lutinhas) são coibidas pelos adultos por interpretá-las como prejudiciais às crianças, pois estariam estimulando a violência.

Estereótipos sobre as lutas são ainda mais reforçados quando praticantes de alguma modalidade se envolvem em ações desviantes, como brigas e agressões, pois em vez da conduta ser atribuída a questões morais, temperamentais e pessoais do sujeito envolvido, o ato é concebido como decorrente do vínculo com as lutas.

Diante do ranço criado em relação às lutas como lazer, em que seus praticantes são concebidos como arruaceiros e vagabundos, parte considerável da população acaba não despertando atenção e interesse por 
essas atividades, colaborando para que, além de pouco fazerem parte da vida cotidiana, não estejam no bojo de suas reivindicações.

Em relação à presença das lutas no lazer da população brasileira, pesquisa desenvolvida pelo Ministério do Esporte identificou que pequena parcela da população se envolve com esse tipo de prática corporal no tempo de lazer - caratê $(1,4 \%)$, capoeira $(1,2 \%)$, boxe $(0,4 \%)$, jiu-jítsu $(0,3 \%)$, MMA $(0,2 \%)$, muay thai $(0,2 \%)$ e judô $(0,1 \%)$. Estudos realizados com populações regionalizadas observaram que, em algumas ocasiões, as lutas nem aparecem entre os esportes citados, como observado com crianças de Florianópolis, Santa Catarina (Costa; Assıs, 2011), adolescentes de Fortaleza, Ceará (Freitas et al., 2010), adultos de São Paulo, São Paulo (Zanchetta et al., 2010) e idosos de Campinas, São Paulo (ZAitune et al., 2007).

Em nossa análise, o tempo de lazer não se configura como oposição ao tempo de trabalho, mas sim ambos constituem elementos que se inter-relacionam e se complementam, uma vez que perfazem o tempo social e devem dispor da mesma relevância em nossa vida. Se pautar a vida tão somente no trabalho não é desejável, limitá-la ao lazer nos parece entediante.

Quanto às lutas, embora todas envolvam um enfrentamento físico entre oponentes em ações que visam ao desequilíbrio, à contusão, imobilização e exclusão do adversário de uma área delimitada, ao contrário do que permeia o imaginário de parte da população, compreendemos que essas possibilidades de lazer não figuram, por si só, como promotoras de violência, uma vez que são pautadas em filosofias ligadas a questões históricas e culturais de diferentes países, em que seus seguidores zelam pelo seu cumprimento e disseminação, sendo os discípulos intimamente vinculados aos mestres, os quais exercem influência sobre o comportamento dos praticantes, fazendo desse processo uma relevante oportunidade formativa.

Torna-se importante então que atores políticos envolvidos com o lazer, respeitando a diversidade cultural, façam de suas intervenções um processo duplamente educativo: educação para o lazer e educação pelo lazer, que poderão corroborar na superação de percepções de que as lutas são atividades violentas, assim como a ideia de que o lazer se configura como atividade de pessoas desocupadas, vagabundas, violentas e promotoras de arruaças. 


\section{Lutas como possibilidade de educação pelo lazer e para o lazer}

A educação para o lazer pode se dar com a iniciação da população nos diversos conteúdos culturais, entre eles o físico-esportivo, no qual as modalidades de lutas se encontram inseridas, o que, a partir de experiências exitosas, contribuiria para que os envolvidos passassem a dar mais valor a esse tipo de atividade, como também a buscar ocupar seu tempo disponível com o lazer.

Educar para o lazer pode colaborar para que a população tenha acesso aos diferentes movimentos corporais que compõem os golpes de uma luta. Pode auxiliar ainda na compreensão de que o aproveitamento do tempo disponível com esse tipo de experiência vai além de oportunidades veiculadas pela mídia. Contribuiria, ainda, para que a população entenda que existe um rol diversificado de possibilidades de ocupação do tempo disponível que, além dos tratados como produtos e comercializados pela indústria cultural, também se fazem presentes no contexto de sua comunidade, estando vários deles vinculados à cultura local, carregando a identidade desse contexto.

No que tange ao interesse físico-esportivo, em específico as lutas, objeto deste texto, torna-se essencial que diferentes vertentes (capoeira, judô, tae kwon do, caratê, jiu-jítsu, boxe, sumô, muay thai, kung fu, entre outras) sejam disseminadas, facilitando para que a dinâmica e a filosofia de cada uma delas sejam conhecidas, favorecendo a superação de interpretações equivocadas e preconceitos. Contudo, ao incentivar e disponibilizar um rol de possibilidades de vivência de lutas, faz-se necessário respeitar o interesse da comunidade em optar por participar ou não.

Além de inseridos em diversos conteúdos culturais e vertentes de lutas, faz-se imperioso também que haja um processo pedagógico conduzido por metodologias que promovam a atuação dos envolvidos em níveis críticos e crítico-criativos, chamando atenção para os condicionantes sociais aos quais as oportunidades de lutas encontram-se submetidas e não se limitando a aprendizagem das técnicas básicas que as compõem.

De acordo com Marcellino (2001), além de inserir a população nos seis interesses culturais do lazer (educação para o lazer), é necessário que experiências de lazer também estejam pautadas na superação de níveis menos elaborados (conformistas) para níveis mais elaborados e complexos, em que a criticidade e a criatividade favoreçam a percepção dos condicionantes sociais aos quais o lazer se encontra envolvido e contribuam para o desenvolvimento pessoal e social da população. 
Isso significa que não é suficiente apenas a prática dos movimentos técnicos que compõem uma luta, reflexões críticas que busquem identificar diferentes aspectos relacionados a ela, assim como a superação tradicional da vivência dessa prática, também se fazem necessárias. Além disso, é importante um posicionamento crítico-criativo que, além da identificação dos fatores condicionantes, busque possíveis soluções para que transformações ocorram.

A possibilidade de materialização de um processo duplamente educativo no lazer pode ocorrer pela utilização de metodologias diversificadas no ensino dos movimentos, como a metodologia do ensino de lutas em jogos de oposição. Outra possibilidade consiste na tematização das lutas, em que diferentes dimensões sociais relacionadas a essa prática sejam trabalhadas.

\section{0 ensino das lutas por meio de jogos de oposição}

Sobre o tratamento pedagógico do ensino de lutas, tanto em projetos sociais como em outros estabelecimentos de prática, o que temos percebido em nossos estudos e experiências profissionais é que o processo ensino-aprendizagem tem sido pautado em "metodologias tradicionais". Tais metodologias caracterizam-se pelo excesso de repetições e uma exagerada cobrança na execução perfeita dos movimentos que estão sendo vivenciados.

Nesse tipo de metodologia, frequentemente as atividades apresentadas para o praticante consiste na reprodução fiel dos movimentos (muitos de difícil execução) específicos de cada modalidade de luta. Fato que em vários casos pode levar ao praticante a sensação de incapacidade e, por consequência, a falta do prazer necessário na vivência das atividades voltadas ao lazer.

Em que pesem as contribuições dessa metodologia no processo ensino-aprendizagem das lutas, defendemos a possibilidade da utilização de outras metodologias de ensino, que possam oferecer a oportunidade ao praticante de conhecer e vivenciar um conjunto de atividades que lhe tragam, para além do desempenho técnico esportivo, novas e exitosas experiências de diversão e aprendizado.

Vislumbramos essa possibilidade no uso de metodologias pautadas no ensino das lutas por meio de jogos de oposição, o que pode figurar como uma alternativa, pois os jogos permitem que as características básicas das lutas (imprevisibilidade, regras, oposição direta ao adversário, 
entre outras) sejam preservadas. O uso dos jogos de oposição como método para ensinar as lutas tem sido tema de estudos realizados ultimamente no Brasil. São muitos os professores que encontraram nessa metodologia de ensino uma forma de vivenciar o aprendizado propiciando uma experiência lúdica para seus participantes.

Ainda, a utilização dos jogos como estratégia metodológica para o ensino das várias modalidades de lutas torna-se mais viável para um número maior de professores. Tal fato se deve porque no ensino tradicional é necessário um profundo conhecimento específico do que cada modalidade exige, o que invariavelmente demanda muito tempo de formação, e isso nem sempre é possível para parte dos profissionais envolvidos com a temática.

Além do mais, a partir da utilização dos jogos de oposição como método de ensino, o professor, mesmo sem ter um conhecimento específico aprofundado de cada tipo de luta, pode proporcionar em suas aulas a oportunidade de os alunos vivenciarem experiências variadas de diversas modalidades em um mesmo espaço de aprendizado. Ou seja, o professor pode, de forma lúdica e agradável, proporcionar momentos de aprendizagem de conteúdos da capoeira, do judô e/ou do caratê, entre outras, usando, para tanto, os jogos de oposição como estratégia metodológica de ensino.

Darido e Rufino (2015, p. 57) compreendem a oposição dentro dos esportes de lutas: "A característica de oposição talvez seja um dos elementos mais visíveis que compõem os aspectos universais das lutas corporais. De maneira geral, há determinado nível de oposição em qualquer modalidade de luta, independente de seus objetivos e regras".

$\mathrm{O}$ que estamos chamando de jogos de oposição neste texto tem como principais características o ato de confrontação direta contra o oponente, que pode acontecer entre duplas, trios ou até mesmo em grupos. Seus objetivos principais são: subjugar o adversário por meio de técnicas e estratégias de ataque e defesa; impor-se fisicamente ao oponente, contudo, respeitando às regras e, acima de tudo, garantindo a segurança do praticante durante o desenvolvimento das atividades.

No decorrer do desenvolvimento dos jogos de oposição, deve-se considerar certos cuidados para garantir a participação com a maior segurança possível. Com isso, propor limitação na duração de cada jogo e delimitar o espaço de desenvolvimento da ação constituem alguns cuidados a serem tomados. Outra providência a ser pensada, com o intuito de manter a segurança na atividade, é os praticantes não 
utilizarem acessórios, como anéis, brincos, colares e outros que possam ferir um dos participantes. Retirar sapatos ou tênis quando necessário é outra cautela que pode ajudar a manter a segurança dos participantes da atividade.

Está presente nos jogos de oposição, além de questões cognitivas, sociais e afetivas, o desenvolvimento de ações motoras comuns a diversas formas de lutas. Podemos citar como exemplos dessas ações os atos de empurrar, puxar, desequilibrar, esquivar, cair, rolar, agarrar, chutar e socar.

A seguir, apresentamos exemplos de jogos que, quando executados, desenvolvem conteúdos presentes em diversas modalidades de lutas. Lembramos que os exemplos de atividades são apenas para ilustrar a temática e, principalmente, para o incentivo à pesquisa de outros jogos de oposição que poderão ser utilizados no desenvolvimento de ações na prática das lutas.

Lembramos também que as atividades apresentadas podem ser modificadas de acordo com as necessidades de cada local ou momento em que será desenvolvida. Para tanto, usaremos como base de consulta uma adaptação dos estudos de Darido e Silva (2014) para as atividades de A a D. Já as atividades E e F foram construídas ao longo de nossa experiência, no convívio com o ensino das lutas.

\section{Atividades}

A. Pega-pega das lutas: os praticantes devem pendurar na roupa que estiverem usando, em sua cintura, uma fita (de pano, TNT, plástico ou outro material) de aproximadamente $30 \mathrm{~cm}$. O objetivo da atividade é conquistar o maior número de fitas das outras pessoas, sem com isso perder a sua própria fita. Os participantes podem proteger suas fitas, impedindo com as mãos ou usando esquivas. As pessoas que forem perdendo as fitas podem continuar na atividade buscando ainda conquistar o maior número de fitas possível. Ganha a atividade quem, ao final do tempo estipulado, tiver conseguido o maior número de fitas. Explique para os participantes que o objetivo é retirar com as mãos algo preso na outra pessoa, ou seja, o foco é o outro e é móvel, aspecto que encontramos de modo geral nas lutas. 
B. Luta das bexigas: cada participante deve receber uma bexiga e enchê-la. Inicialmente, os participantes devem realizar movimentos relacionados às lutas, como socos, chutes, joelhadas, entre outros, sem deixar a bexiga cair ao chão (não pode segurar a bexiga, somente tocá-la). Em seguida, a atividade deve ser praticada em duplas: cada participante deve concentrar-se em não deixar a sua bexiga cair e tentar retirar a bexiga do outro, mantendo as duas no ar utilizando apenas movimentos de luta.

C. Lutando por território: dividir os participantes em duplas. Cada dupla precisa ter um arco ou bambolê para desenvolver a atividade. Uma das pessoas deve entrar no arco, ficando a outra do lado de fora. As duplas começam a se enfrentar: o objetivo de quem está do lado de fora é empurrar com as mãos aquele que se encontra dentro do arco, fazendo-o desequilibrar e/ou sair (pisar fora do espaço delimitado pelo arco). Os participantes da atividade somente podem se tocar usando a palma das mãos. Em um segundo momento, os participantes devem trocar de lugar.

D. Jogo de imobilizar: em duplas, com os participantes sentados, um de costas para o outro. Eles devem entrelaçar os braços e apoiar cada um nas costas do outro. O objetivo é que os participantes consigam se desvencilhar um do outro. Para tanto, primeiro um participante apenas se concentra em manter a outra pessoa presa, enquanto esta deve tentar fugir. Em seguida, as atividades são trocadas e quem estava na condição de ficar imobilizado passa a tentar fugir.

E. Luta do tapinha: dividir os participantes em duplas, que devem ficar em pé, um de frente para o outro e em forma de guarda (com os braços e antebraços semiflexionados, com as mãos na altura dos ombros). O objetivo da atividade é que uma pessoa toque (execute um tapinha) com a palma das mãos nos ombros do oponente, não permitindo, com esquivas e movimentos de bloqueio com as mãos, que o oponente faça o mesmo em seus ombros. Em um segundo momento, os toques podem ser liberados também para a região do tórax (peito e barriga). Ganha a atividade quem conseguir executar 
o maior número de toques nas regiões permitidas durante o tempo estipulado previamente.

F. Estourando bexigas: em duplas, com uma bexiga amarrada por um barbante de aproximadamente $30 \mathrm{~cm}$ em cada um dos pés. O objetivo da atividade é que cada participante tente estourar as bexigas do oponente chutando ou pisando nela, não permitindo, com esquivas, que o adversário consiga estourar as suas bexigas. Ganha a atividade quem primeiro conseguir estourar as duas bexigas do adversário.

\section{Tematização das lutas e possibilidades educativas no lazer}

As lutas, seja por meio de sua prática, de sua contemplação em eventos esportivos televisionados (ou presencialmente nos espaços de competições), ou seja pelo estudo de aspectos conceituais sobre o tema ou análise dos valores envolvidos em sua vivência, mantêm íntima relação com diversas dimensões sociais da vida, entre elas o gênero, a ética, a violência, as mídias, as telecnologias e o mundo virtual, sendo a criação de possibilidades para vivênciá-las em programas de fomento do esporte e lazer um importante mecanismo para o desenvolvimento pessoal e social.

Ao articular lutas e lazer, esperamos que os atores envolvidos exerçam a função de transformadores da realidade que permeia a vida da população foco das intervenções, colaborando para que as experiências advindas do lazer não ocorram como mecanismo de evasão dos transtornos cotidianos, mas sim que figure como um tempo/espaço que contribua para a emancipação dos envolvidos.

Para exemplificar, optamos por apresentar algumas reflexões sobre atuações possíveis diante da tematização das questões afetas a lutas e gênero.

Historicamente, as mulheres têm sofrido preconceitos e discriminação em diversos setores da sociedade, pois, além de ter sido construída uma percepção equivocada sobre seu papel social, isto é, de esposa, mãe e dona do lazer, interpretações como essas também foram extendidas ao âmbito esportivo. Por muito tempo às mulheres foi permitida tão somente a participação/prática em modalidades tidas como estéticas e belas, não envolvendo grandes esforços e contatos físicos.

Mesmo que avanços tenham ocorrido diante dos históricos enfrentamentos travados contra preconceitos, percepções estereotipadas sobre 
a participação feminina datam antes mesmo dos Jogos Olímpicos da Antiguidade, perpassando pelos Jogos Olímpicos da Era Moderna e mantendo-se em diversas ocasiões esportivas na sociedade contemporânea, pois, se em sua versão original as mulheres foram proibidas até mesmo de assistirem a esses eventos, na versão da Era Moderna, datada de 1896, Barão de Coubertin ressaltava que no contexto esportivo a participação das mulheres deveria limitar-se ao coroamento dos vencedores, pois, segundo ele, envolvê-las nas competições contrariaria a lei da natureza.

No que tange às lutas, percepções como essas corroboraram para que a integração feminina em provas de lutas nos Jogos Olímpicos ocorresse muito tempo após a inserção dos homens, pois, tomando o boxe como exemplo, há uma distância de 108 anos, sendo as mulheres inseridas apenas em 2012.

Construções sociais sobre ações cotidianas (trabalho, jogo, lazer) tratadas diferentemente como apropriadas a homens ou mulheres colaboraram para que as mulheres que buscam sua inserção em esportes que exigem maior contato físico e aplicação de força, características tidas como violentas, sofram preconceitos e discriminação, sendo frequentemente julgadas como atividades exclusivas para homens. Tal compreensão faz com que as mulheres que se envolvem com esse tipo de lazer sejam estereotipadas como masculinizadas e, por vezes, concebidas como lésbicas.

Entre os esportes nos quais as mulheres são subjugadas com interpretações preconceituosas, discriminatórias e estereotipadas em relação ao gênero, podemos citar as lutas em suas diferentes vertentes: boxe, judô, caratê, jiu-jítsu, MMA, tae kwon do, entre outras.

Essa condição foi observada em estudo desenvolvido por Cardoso, Sampaio e Santos (2015) com lutadoras de boxe. Na ocasião, as lutadoras sinalizaram que, além de não obterem apoio social familiar para a prática do esporte, muitas pessoas as viam como lésbicas, o que, segundo Cardoso et al. (2012), ocorre por não estarem em consonância com uma cultura de esporte tradicional, que vislumbra na mulher um ser frágil, meigo e dócil, que não deve submeter-se a ações que envolvem aplicação de força física.

A submissão da mulher a julgamentos preconceituosos e discriminatórios, assim como as dificuldades que elas enfrentam ao tentar adentrar ao mundo das lutas, encontra-se retratada no filme Menina de ouro (2004), que tem como protagonista Hilary Swank (Maggie Fitzgerald). Quando analisado tomando como base uma percepção crítica e criativa 
do lazer, esse filme configura-se como veículo pedagógico para a emancipação por intermédio de oportunidades contemplativas.

Maggie tinha o sonho de tornar-se uma lutadora profissional de boxe. Contudo, inicialmente, além de dispor de pouca habilidade técnica para esse esporte de alto rendimento, seus recursos econômicos eram escassos, tornando sua vida ainda mais difícil. A fim de alcançar seus sonhos, contacta Frankie Dunn, técnico de diversos campeões na modalidade, tentando conseguir com isso seu apoio e adesão como treinador. No entanto, ao contrário do que Maggie esperava, Frankie dirige-se a ela com frases que sinalizam sua percepção sobre a questão: "Sempre que você o toca [referindo-se ao puching ball], você prejudica o meu negócio"; "Vai perder seu tempo porque é velha demais"; "Você não vai chorar, né?". Ou seja, ao buscar apoio de um treinador, Maggie é submetida a diversos constrangimentos, preconceitos e discriminações, uma vez que o treinador entendia que o boxe era um esporte destinado apenas para homens, recusando-se, a princípio, a treiná-la.

Debater o espaço ocupado pelas mulheres nas lutas constitui-se em um importante mecanismo de educação para e pelo lazer, promovendo maior conscientização sobre a questão ao possibilitar a reflexão crítica e crítica-criativa pela vivência prática ou contemplativa das lutas.

\section{Considerações finais}

Ao longo deste texto debatemos sobre como historicamente as questões relacionadas ao lazer e às lutas foram tratadas de modo estereotipado, o que contribuiu para que a ocupação do tempo social com esses tipos de atividades por parte da população fosse restrita.

Considerando a importância de uma vida equilibrada, com o preenchimento do tempo social com diversas atividades, entre elas a de lazer, assim como a importância da vivência do lazer em níveis médios (crítico) e elevados (crítico-criativo), advogamos a relevância de um duplo processo educativo nas experiências de lazer, as quais poderão ocorrer com a utilização de metodologias diferenciadas de ensino de lutas, como a pautada nos jogos de oposição, assim como por meio da proposição de temas, como gênero e lutas.

Por fim, sinalizamos que as reflexões aqui apresentadas figuram apenas como possibilidades, devendo novas propostas serem elaboradas e apresentadas à comunidade acadêmica e profissional a fim de promover 
a ampliação da inserção da população nas oportunidades de vivência das lutas no lazer.

\section{Referências}

Cardoso, B. L. C.; Assumpção, L. O. T.; Silva, J. V. P.; Sampaio, T. M. V. Mulheres no boxe: percepções sociais de uma luta sem luvas e fora dos ringues. Motricidade, Ribeira de Pena, Portugal, v. 8, n. 2, p. 259-268, 2012.

Cardoso, B. L. C.; Sampaio, T. M. V.; Santos, D. S. Dimensões socioculturais do boxe: percepção e trajetória de mulheres atletas. Movimento, Porto Alegre, v. 21, n. 1, p. 139-154, 2015.

Costa, F. F.; Assis, M. A. A. Nível de atividade física e comportamentos sedentários de escolares de sete a dez anos de Florianópolis/SC. Revista Brasileira de Atividade Física e Saúde, Florianópolis, v. 16, n. 1, p. 47-54, 2011.

DARIDo, S.; Rufino, L. O ensino das lutas na escola: possibilidades para a educação física. Porto Alegre: Penso, 2015.

DARIDO, S.; SiLva, L. Práticas corporais e a organização do conhecimento: lutas, capoeira e práticas corporais de aventura. Maringá: Editora UEM, 2014.

Freitas, R. W. J. F.; Silva, A. R. V.; Araújo, M. F. M.; Marinho, N. B. P.; Damasceno, M. M. C.; Oliveira, M. R. Prática de atividade física por adolescentes de Fortaleza, CE, Brasil. Revista Brasileira de Enfermagem, Brasília, v. 63, n. 3, p. 410-415, maio/jun. 2010.

Marcassa, L. A invenção do lazer: educação, cultura e tempo livre na cidade de São Paulo (1888-1935). 2002. 204f. Dissertação (Mestrado em Educação) - Universidade Federal de Goiás, Goiânia, 2002.

Marcellino, N. C. Estudos do lazer: uma introdução. 3. ed. Campinas: Editora Autores Associados, 2001.

Menina De Ouro. Produção de Albert S. Ruddy, Paul Haggis e Tom Rosenberg. Direção de Clint Eastwood. Estados Unidos: Warner Bros, 2004.

Zaitune, M. P. A.; Barros, M. B. A.; César, C. L. G.; Carandina, L.; Goldbaum, M. Fatores associados ao sedentarismo no lazer em idosos, Campinas, São Paulo, Brasil. Cadernos de Saúde Pública, Rio de Janeiro, v. 23, n. 6, p. 1.329-1.338, 2007.

Zanchetta, L. M.; Barros, M. B. A.; César, C. L. G.; Carandina, L.; Goldbaum, M.; Alves, M. C. G. P. Inatividade física e fatores associados em adultos, São Paulo, Brasil. Revista Brasileira de Epidemiologia, São Paulo, v. 13, n. 3, p. 387-399, 2010. 


\section{CAPÍTULO 10}

\section{CAPOEIRA E JOGOS CORPORAIS}

Coriolano P. da Rocha Junior

Romilson Augusto dos Santos

Capoeira, palavra que na língua portuguesa assume diversos sentidos. Entre eles, podemos indicar alguns: "área de mato cuja vegetação anterior foi roçada e/ou queimada para cultivo ou outros fins, e que se está renovando; arte marcial de ataque e defesa introduzida no Brasil por escravos bantos; capoeiragem"'.

Essas definições ganham sentido ou ficam vazias, depende daquilo que se busca ou da forma como se vê o termo, ou seja, é preciso mais que uma explicação isolada, é preciso olhar o contexto. Nesse sentido, concordamos com Koselleck (1992, p. 135), quando afirma "que cada palavra remete-nos a um sentido, que por sua vez indica um conteúdo". Ou seja, para consolidar nosso modo de interpretar capoeira, entender seu significado é uma ação importante e necessária.

Melo (2010, p. 69), em um diálogo com o mesmo Koselleck, apresenta-nos a concepção de que "uma experiência histórica específica gera a necessidade de um termo que a conceitua[e]; esse termo/conceito torna possível (inclusive enquadrando, mas também apontando desdobramentos) a experiência histórica”.

Em nosso caso, nos interessa neste estudo a capoeira vista como uma prática corporal, uma atividade que traz em si significados, interpretações e valores que carregam sentidos, que podem ser diversos. Para além das diferentes compreensões registradas em dicionários, importanos analisar aquilo que expressa a capoeira e que nela se manifesta.

1 Dicionário Eletrônico Houaiss da Língua Portuguesa. Disponível em: < https://houaiss. uol.com.br/pub/apps/www/v3-3/html/index.php\#1>. Acesso em: 23 abr. 2018. 
Sobre a interpretação de práticas corporais, Rocha Junior e Pinto Junior (2011, p. 105) afirmam que essas são "atividades humanas construídas ao longo da história e valorizadas culturalmente, com forte representação e significação em cada comunidade e que são expressas em atividades artísticas, físicas e esportivas".

Assim, tomando a capoeira como uma prática corporal, a nossa motivação concentra-se em interpretar o fenômeno, suas formas de atividade, suas possibilidades de vivência, que aparecem no bojo da sociedade e que ganham expressão em virtude dos sentidos a ela atribuídos, dos espaços de ação, das intencionalidades de quem com ela lida, ou seja, queremos melhor observar a experiência e a diversidade nela contida, para pensar proposições de intervenção no campo do lazer.

Em suas raízes, a atividade da capoeira encontra-se visceralmente identificada com a população negra no Brasil, sendo uma manifestação corporal que expressa formas de cultura popular. Com base em um viés histórico, podemos entender que a capoeira, ao longo dos tempos, manteve-se sob diferentes olhares e reações da sociedade e do poder instituído.

Com raízes africanas e brasileiras, que em sua constituição dialogaram e ainda dialogam com a realidade de uma parcela da população e da própria condição do país, a capoeira, vista como uma prática que tem base nas dinâmicas culturais do povo negro no Brasil, também representa em sua organização social um tempo, uma possibilidade de sociabilidade dessa gente, que em sua condição de brasileiros natos ou para cá trazidos à força, para viverem em condição de escravidão, sempre se viu colocada à margem da sociedade, de ideais condições de vida, exposta à humilhação e violência de toda espécie.

Mesmo sob circunstâncias de violação de direitos, de condição humana, essa população resistiu e criou meios de sobrevivência no espaço nacional. Entre essas formas, as práticas culturais, incluindo a capoeira, foram modos de afirmação de sua identidade, de sua posição e condição de valor para o país.

Melo (2007), ao analisar a capoeira, assevera que essa cultura traz consigo polêmicas acerca de suas origens, ou seja, que não há como se definir se suas bases são rurais ou urbanas. Independentemente de afirmar sua base geográfica, e mesmo considerando desnecessário, já sabemos que sua raiz social está na população negra brasileira e/ou africana, ou melhor, afro-brasileira.

Como uma manifestação típica da parcela negra que habitava o país, em suas origens a capoeira acabou sendo alvo de um processo 
discriminatório e de perseguições policiais, políticas e judiciais, isso já no século XIX, quando por um olhar preconceituoso estava "muito relacionada à criminalidade e a arruaças" (Melo, 2007, p. 25).

Ainda no que se refere a essa questão, Oliveira (2004), em uma análise sobre a capoeira na Bahia nas décadas iniciais do século $\mathrm{xx}$, identifica que essa expressão estava inserida em um universo de criminalidade, reforçando a tese de que a sua prática e seus praticantes, por razões de repressão e discriminação, eram deixados à margem da sociedade organizada.

Em contrapartida, ao reconhecermos o jugo das estruturas de poder instaladas em relação à capoeira e a quem a praticava, como forma de controle social, devemos entender que a atividade, justo por representar a identidade de um povo, era - e continua sendo - uma forma de resistência que se mobilizava pelo reconhecimento e valorização cultural de suas tradições.

Ao reconhecermos que no Brasil as bases sociais da capoeira estão assentadas entre os séculos XIX e Xx, devemos também identificar que nesse mesmo período as cidades brasileiras passavam por um processo de modernização, ou ao menos havia a tentativa.

Nessa época existiu um discurso propagando que o ser humano e as cidades deveriam ser modificados, para adequarem-se ao que era tido como moderno e ideal. Assim, o novo homem deveria ter uma nova saúde, exibir corpo saudável, mais adaptado ao calor do trópico, em uma tendência na qual as práticas seriam construtoras de outra constituição corporal. No entanto, não deveria ser a capoeira a permitir isso, mas sim os esportes, uma nova forma de atividade que se instalava no país com base no que fora visto em países europeus, sendo isso mais uma ação do ideal modernizante.

Nessa linha, Rocha Junior (2011) nos mostra que esses projetos de modernidade não se assentavam apenas em tentativas de remodelação da estrutura urbana das cidades, mas sim era também preciso mudar comportamentos, moldar hábitos, modelar as práticas sociais e culturais, fazendo-as se identificarem com padrões europeus, distante do modelo de formação da sociedade brasileira, na qual a presença negra sempre se fez, mesmo que sob forte e expressiva violência.

A tentativa de instalação de uma modernidade europeizante buscava criar espaços sociais nos quais a elite política e econômica pudesse fazer-se presente, desfilar suas vestes e os modos tidos como chiques. Para tanto, era necessário renegar toda uma população e seus hábitos, no 
caso a negra, e com ela a capoeira. Entretanto, tal ação não se deu sem que houvesse uma reação, que foi acima de tudo cultural. Para Rocha Junior (2011, p. 22),

o processo modernizador não se deu sem que houvesse uma ação de oposição dos rejeitados, que, mesmo sob as forças do poder central e sofrendo as agruras de seu deslocamento e as violências contra seu modo de cultura, souberam agir. [...] Ou seja, vê-se mesmo uma reação popular às investidas de controle cultural por parte da elite, lutando para manter vivas suas manifestações, mas também buscando apreender as que eram vividas pela elite.

Nesse mesmo sentido, Carvalho (2009, p. 41) afirma que "o mundo subterrâneo da cultura popular engoliu aos poucos o mundo sobreterrâneo da cultura das elites". Se as iniciativas por modernidade nas cidades tentaram instalar um padrão homogêneo, entendemos, em acordo com Rocha Junior (2011, p. 23), que "a cultura foi um foco das ações modernizadoras; é nela que se apoiaram as perspectivas de mudanças do cotidiano das cidades, para além das paredes dos prédios e das vias públicas".

Da mesma forma, a cultura foi um espaço para a população marginalizada se posicionar na sociedade, uma forma de resistir e fazer valer seus interesses e modos de organização, e no caso, com a capoeira, iniciando-se na rua, já que esse ambiente era o cenário de prática, constituição e existência dessa atividade. Segundo Oliveira (2004, p. 30), a capoeira e quem vivia a sua prática "eram elementos das ruas, pois nela está seu sustento e o seu lazer. Era um personagem do cotidiano urbano que tinha de respeitar as regras que o subordinava e lhe era subordinado, o mundo das ruas".

É sabido que essa condição cultural marginal, em diferentes períodos históricos de nosso país, acabou por tornar a capoeira e sua prática atividades ilegais, conforme previa o Código Penal Brasileiro, isso desde o século XIX. Essa situação só foi revertida a partir da década de 1940, mas essa circunstância não impediu a atividade de prosseguir existindo, de criar meios de "sobrevivência", estando imbricada na sociedade, em seus vários estratos, continuando a viver como uma dinâmica social que a dava potência e a fazia, mesmo que aos poucos, ganhar relevância social.

No desenrolar dos tempos, a capoeira foi ganhando espaço e projeção, saindo de uma imposta invisibilidade e marginalização até se tornar uma atividade de interesse e com circulação em variados espaços, com 
diferentes proposições. Chegou-se a aventar a possibilidade de a capoeira tornar-se um método ginástico brasileiro. Tal proposição foi pensada com base na interpretação de que essa atividade assumia ares verdadeiramente nacionais, podendo ser representativa de um modelo de prática corporal que deveria ser incorporado pela nação, em prol do bom desenvolvimento do homem e da nação. Castro Júnior (2010) e Melo (2007) asseveram que essa idealização foi pensada pela primeira vez, em 1907, no Guia do capoeira ou gymnastica brazileira, e depois retomada em 1928, época em que a atividade ainda era reprimida legalmente, mas também relatam que mais tarde, com Inezil Penna Marinho ${ }^{2}$, a proposta foi com mais veemência defendida sem, contudo, ser efetivada.

A primeira iniciativa de sistematização do método de ginástica brasileira foi o guia Capoeira ou Ginástica Brasileira, no ano de 1907, cujo autor identificava-se pelas iniciais de ODC. Seu seguidor foi Anibal Burlarmaqui, que retomou, em 1928, com o seu trabalho Ginástica Nacional (Capoeiragem) Metodizada e Regrada, a tentativa de fazer da capoeira a ginástica nacional. Contudo, foi o professor Inezil Pena Marinho o grande organizador, com sua obra Subsídios para o Estudo da Metodologia da Capoeira do Treinamento da Capoeiragem, cujo objetivo era transformar a capoeira em uma prática esportiva para afirmar um projeto de sociedade que utilizava os elementos da cultura popular na constituição de uma identidade voltada para os mecanismos do nacionalismo através do patriotismo [CASTRO JúNIOR, 2010, p. 92].

A solidificação da capoeira, como uma atividade para além da condição marginal da rua, contou com grande contribuição de seus mestres, pessoas que em sua prática e vivência, além de exímios praticantes, tornaram-se referências, "professores" da atividade, no sentido mais pleno da palavra, ou seja, com a preocupação de formar não apenas praticantes, mas sim pessoas que soubessem reconhecer as tradições, a própria história e o valor social da capoeira.

Entre esses nomes, dois podem ser apontados como fundamentais: mestre Bimba e mestre Pastinha. Ambos foram responsáveis pela criação

2 Professor da Escola Nacional de Educação Física e Desportos, da Universidade do Brasil. Pensador e intelectual da educação física, com extensa lista de obras publicadas e relevante contribuição para a área. 
de uma linha de prática da atividade, que, mesmo assumindo interpretações e dando sentidos diversos à capoeira ${ }^{3}$, o que resultou em modelos que assumiram nomes específicos, a capoeira angola e a capoeira regional, foram, sem dúvida, baluartes da experiência social que é a capoeira.

Valendo-nos de um olhar acerca da constituição da capoeira, de seu valor e mérito, interessa-nos, sobremaneira, interpretá-la sob o viés do lazer como uma atividade possível nesse tempo social.

Reconhecemos que a capoeira, com seus arranjos de organização, suas tradições e sua multiplicidade de linguagem, pode assumir, no lazer, lugar especial como interesse de prática. Para melhor organizar nossa construção, primeiro trazemos uma compreensão sobre lazer. Segundo Dumazedier (2001, p. 34), o lazer é um:

conjunto de ocupações às quais o indivíduo pode entregar-se de livre vontade, seja para repousar, seja para divertir-se, recrear-se e entreter-se ou, ainda, para desenvolver sua formação desinteressada, sua participação social voluntária, ou sua livre capacidade criadora, após livrar-se ou desembaraçar-se das obrigações profissionais, familiares e sociais.

Ainda sobre lazer, outra compreensão é a trazida por Camargo (1986, p. 97), que afirmar que esse é:

conjunto de atividades gratuitas, prazerosas, voluntárias e liberatórias, centradas em interesses culturais, físicos, manuais, intelectuais, artísticos e associativos realizados num tempo livre roubado ou conquistado historicamente sobre a jornada de trabalho profissional e doméstico.

Nessa esteira, podemos aqui compreender o lazer como:

uma ação humana, desenvolvida a partir de práticas culturais, que congregam variados interesses, acontecendo e ganhando sentido no tempo do não trabalho, no tempo disponível, livre das mais diversificadas obrigações do homem [Rocha Junior; PINTo Junior, 2011, p. 109].

3 Não nos cabe neste texto debater as diferenças entre capoeira angola e capoeira regional, e nem queremos assumir defesa de uma ou de outra, até pelo fato de lidarmos aqui com a prática como um todo. A intenção foi apenas a de situar a existência de modelos que em si possuem variação quanto à prática e seus ideais. 
Pela perspectiva do lazer e com a compreensão da capoeira como uma prática corporal, que se manifesta sob diferentes sentidos e expressões, em Dumazedier (1980) encontramos uma construção denominada de interesses culturais do lazer. Também outros autores brasileiros, como Camargo (1986), Marcellino (1996) e Melo e Alves Junior (2003), tratam os interesses culturais em suas obras, sempre tendo Joffre Dumazedier como referência.

É dessa maneira que a capoeira, justo por sua multiciplicidade de manifestações e expressões, ganha sentido como interesse cultural do lazer, que na verdade não pode ser enquadrada em uma linha, pois nela cabem sentidos variados, que a fazem ganhar valor e justificar-se como atividade de lazer.

Sendo assim, adiante apresentaremos a capoeira como uma forma e experiência de lazer, trazendo possibilidades de trato com sua prática e vivência. Entendendo o sentido de experiência aqui para além de visões preconceituosas, estigmatizantes, normatizadoras e coisificadas dos saberes e conhecimentos que levam a compreensões e percepções, como se fossem epifenômenos, conforme argumenta Macedo (2015, p. 17):

Tomando a centralidade dos nossos argumentos, sabemos que o contexto da valorização socioeconômica dos conhecimentos científicos e acadêmicos vem estigmatizando e normatizando os saberes da experiência, bem como criou um ethos e um habitus pelos quais esses saberes são percebidos como epifenômenos, sem valor explicitativo ou mesmo um perigo para o esclarecimento de realidades humanas. Com isso, criou-se um certo desprezo preconceituoso pelas contribuições heurísticas desses saberes. À medida que os saberes experienciais vêm aos poucos sendo reconhecidos e vem se criando um cenário de respeito e acolhimento, tanto epistemológica quanto heurística e profissionalmente para esses saberes, percebemos um empoderamento técnico e cultural em relação à sua valoração, ao lado de um parasitismo neocolonialista que ainda persiste em ficar e em algumas situações se amplia.

Ainda sobre o sentido de experiência, Castro Júnior (2010, p. 33) nos ajuda a pensar:

a experiência implica a singularidade do despertar, do criar e do fazer; é o lugar da interdeterminação do que ainda não é, em termo definitivo. Na verdade, a cultura dos capoeiras é um conjunto 
múltiplo, polifônico e polirrítmico de fluxos de sentidos, de matérias e de expressões que interagem permanentemente, carregando em si a potência da diferença, do enigma, do silêncio, do inventivo e da irrupção que incorpora o contraditório, o conflito e as intensas lutas de poder que vamos denominar de duplagem cultural.

Nesses termos, devemos pensar a experiência de lazer como possibilidade formativa, que ao mesmo tempo forma os sujeitos e transforma as realidades em que vivem, sentem, agem e praticam a experiência ou as experiências escolhidas no tempo/espaço disponível para sua prática. Nas experiências de lazer encontramos subjetividades, singularidades, ambivalências, contradições, porém encontramos também "campos" fecundos de sociabilidades e de desenvolvimento pessoal, dando sentidos e significados às vivências e práticas realizadas.

Dessa forma, compreender a capoeira enquanto experiência de lazer significa ampliar as possibilidades de olhares sobre essa atividade, sem estabelecer uma ação judicativa em relação às práticas corporais, em cenários de organização e expressão de culturas populares e eruditas. Importa aqui compreender a capoeira para além do já posto, reconhecendo-a em seu processo histórico-cultural, mas ao mesmo tempo dando potência e lugar de empoderamento em campos de visibilidade, fecundidade e possibilidades de intervenção no lazer. Nesses campos, encontramos os jogos de linguagem, o gestual, o jogo de simbologias, os corporais e rítmicos, os jogos rituais e as festas, que se materializam na prática e na vivência da capoeira enquanto lazer.

Reportamos a campos de visibilidade como algo que não deve ser compreendido como fixo; eles são móveis, flutuantes no espaço e no tempo. O campo é território das festas populares, das rodas nas escolas de capoeira, das salas de cinema e das exposições de arte, visto que a cidade de Salvador vinha se modernizando, mas é, também, a linguagem de expressão e de conteúdo do corpo na narrativa dramática. Portanto, o território é formado por esse trânsito, por essa permeabilidade generalizada, por esse sistema de interação. Esse campo é o lugar indeterminado onde o visível é uma qualidade de uma textura, a superfície de uma profundidade. Lugares capazes de transformar a linguagem dos corpos-capoeira numa trama de referências de múltiplas passagens [CASTRO JÚNIOR, 2010, p. 20].

Nesses termos, a capoeira e os jogos corporais configuram-se e materializam-se enquanto prática e vivência do lazer na vida cotidiana dos 
que brincam, jogam, lutam, dançam, apreciam e vivem tais expressões e vibrações culturais presentes nessa atividade. Ela ganha potência enquanto interesse cultural do lazer no espaço/tempo da festa, do jogo, da dança, da arte, da música, da literatura, ou seja, nos espaços/tempo de criação, recriação e de fruição dessas experiências culturais e formativas, em um ato dialógico e dialético entre o ser no lazer e o lazer no ser.

Quando buscamos compreender o ser no lazer e o lazer no ser, estamos partindo do pressuposto que existe um sujeito que pensa, age, interage e reivindica tempos e espaços, para emergir-se em seu processo de devaneio pelo devaneio, subjetividades e abstrações fora das obrigações (trabalho, família, religião, etc.) e que, portanto, devem se constituir em possibilidades para viver e realizar experiências significativas, onde imaginação e memória apareçam em um complexo indissolúvel, na vida do sujeito aprendente, brincante, trabalhador, amante, dentre outros. Consideramos também que tais reivindicações e interações se constituem em um ato dialético e dialógico entre a imaginação e a memória [SANTOs, 2011, p. 52-53].

Na compreensão do "ser no lazer e o lazer no ser", Santos (2011, p. 57) busca explicar o sentido e o significado atribuído por ele a essa sentença:

Aqui se constitui o ser no lazer e o lazer no ser na sociedade contemporânea, ou seja, por um lado, constitui-se o sujeito na ação e dialogicamente teremos a ação no sujeito. O sujeito na ação é aquele que escolhe e se permite vivenciar as diversas experiências e vibrações em forma de expressões culturais em seu sentido pleno, implicado, engajado em seu próprio tempo livre, tais como: dançar, ouvir música, ir ao cinema, ao teatro, etc. A ação no sujeito se configura das mudanças que advirão dessa ação vivida pelo sujeito em seu tempo livre e no seu cotidiano. Para exemplificar, tomemos a seguinte afirmativa: após o sujeito ouvir uma música, ou dançar, ou ir ao cinema, ou ao teatro, ele terá vivido a experiência e as vibrações daquela expressão ou ação cultural e, consequentemente, sofrerá as influências e interferências da experiência vivida, seja ela de natureza qualquer. Portanto, há aqui uma interdependência, um entrelaçamento entre o ser no lazer e o lazer no ser, a partir da sua escolha e veiculação das suas culturas de lazer em seu tempo livre. Envolve o aguçamento de todos os sentidos (visão, audição, tato, paladar, olfato), necessita uma implicação das percepções sensitivas 
plenas, até alcançarmos a transcendência, o estado de "ek-stase" no Ser entre o visível e o invisível.

Ainda Santos (2011), em seus estudos sobre as práticas de lazer das culturas juvenis contemporâneas, utiliza-se de etnométodos para compreender o que esse grupo diz e pensa sobre lazer, educação e formação. A centralidade dos estudos são questões e argumentos heurísticos relativos ao lazer, educação e culturas juvenis e suas relações formativas. Os resultados de suas investigações apontam para a compreensão de que os grupos culturais em seu tempo disponível criam e recriam suas práticas de lazer, principalmente das culturas juvenis contemporâneas em espaços e cenários de organização com suas experiências e vivências culturais, o que o autor vai denominar de etnolazer.

Etnolazer é conceito em construção e, portanto, permite um diálogo aberto para sua formulação. Aqui entendido como um campo de estudo dos grupos culturais, em seus éthos formativos, através de expressões, vibrações, vivências e experiências culturais, desenvolvidas pelos sujeitos em seus cotidianos, realizadas em seu tempo livre, buscando privilegiar o aspecto ontocultural do lazer, em seu sentido pleno de licitude. Ao ter a ideia de cunhar este termo, tomamos como base os etnométodos pelos quais as pessoas criam e recriam suas próprias culturas de lazer [SANTOS, 2011, p. 39].

Assim, nossas análises e compreensões sobre a capoeira e os jogos corporais levam em consideração, além dos aspectos históricos, o aspecto ontocultural do lazer e suas possibilidades de intervenção e mediação social e cultural, no tempo/espaço de sua prática e vivência. Entendendo que a capoeira e os jogos corporais se materializam por meio de práticas, principalmente nos tempos/espaços de experiência do jogo, da dança, da luta e das expressões culturais e da arte, cabe-nos elucidar possibilidades de intervenção no campo do lazer apresentando possibilidades formativas para uma educação plural e cultural.

Nos centros de formação de capoeiristas, bem como nas ruas, festas populares e espaços de sociabilidade, o mestre é quem dá o tom de como será a aula ou jogo da capoeira. Ele convida seus alunos/discípulos/seguidores/aprendizes a se aproximarem do "círculo sagrado", para os jogos corporais, pois terá início a formação da roda e, consequentemente, o jogo de capoeira. Assim se inicia o ritual de interação, que é também formativo. Entre os elementos que compõem a capoeira, fazem-se presentes: os capoeiristas ou capoeiras, os instrumentos musicais 
(berimbau, atabaque, pandeiro, reco-reco e agogô), que assumem uma relação visceral entre corpo sujeito e corpo-objeto, uma relação entretecida de corpos-capoeira, formando a orquestra-coro da capoeira e dos jogos corporais, conforme nos explica Araújo (2015, p. 98):

Uma vez definidas as pessoas que irão compor a orquestra, todas as demais passam a compor o coro. Ou seja, deverão responder ao canto entoado por um dos integrantes da orquestra, ou ainda por alguém que esteja posicionado, na roda, numa das extremidades dos instrumentos. Esta regra indica a necessidade do estabelecimento de uma harmonia comunicacional entre o "puxador" do canto e a orquestra, entre o solo e o coro.

Cada instrumento tem uma função dentro da orquestra, e a roda se inicia com o chamado rítmico emitido pelo berimbau maior e mais grave, chamado gunga, que, ao iniciar um toque (geralmente o toque de Angola), convida o berimbau seguinte, chamado médio, a responder-lhe o chamado através de outro toque que inverta o anterior (geralmente o toque de São Bento Pequeno). Esta inversão tem formato de negação/complementação. Já o terceiro berimbau, chamado de viola ou violinha, entra em seguida e com total liberdade para apresentar-se em variações por estas chamadas de dobrados, fazendo reiteradas variações entre, sobre e com os berimbaus anteriores.

Nesse cenário, que é o ritual de interação, predominam os elementos que determinam e são fundantes para a prática e a vivência da capoeira e dos jogos corporais, que são o berimbau e a musicalidade, que darão o tom do jogo corporal e das expressões e vibrações que compõem a beleza estética, formativa e cultural dessa manifestação das culturas populares. Para uns, isso é lazer; para outros, isso é dever, é obrigação; para outros, ainda, é pura ancestralidade. Para nós, formação humana no tempo/espaço disponível. Aqui se dá a interação social, aqui se dá um encontro de sociabilidades, de mediação cultural e social, com possibilidades de intervenções pelo/no lazer.

Nessa relação de interação social, o toque do berimbau definirá o ritmo do jogo/dança/luta/arte na roda de capoeira. Se o jogo vai ser lento ou rápido, se o jogo vai ser forte ou fraco, vai depender da relação entre quem toca o berimbau e os demais capoeiristas que cantam e jogam, e igualmente pelas deliberações do mestre, que dará as devidas orientações para o bom andamento do jogo/luta na arte de "capoeirar", com a sutileza do seu "toque" também na arte de ensinar e aprender capoeira. 
Trata-se de uma relação formativa e pedagógica que advém, em primeira instância, do ensino-aprendizagem pela via da oralidade, constituída nas culturas populares e que depois se ampliam para outras formas de ensinar/aprender a capoeira e os jogos corporais, por mediação cultural e social. Um verdadeiro processo pedagógico que só os “toques dos mestres" podem ter.

Para compreendermos os "toques dos mestres" com suas sutilezas pedagógicas, é importante considerar dois elementos fortes e incisivos nas manifestações oriundas da diáspora africana. O primeiro está relacionado com a força da cultura oral presente no universo simbólico da capoeira, aquilo que Antônio Bahia chamou de enunciado verbal ao se referir à comunicação do professor com os alunos em uma determinada atividade, e aqui é recolocar como enunciado oral, [que] tem a ver com a força da oralidade na transmissão do conhecimento, nos toques dos mestres, nas suas histórias, nos seus contos, nos seus discursos, nos conselhos dados, nas explicações de como as coisas funcionam, ou seja, toda potência do corpo-voz reverberando nos corpos dos aprendizes [CASTRO JúnIOR, 2010, p. 41].

Depois que o berimbau toca, os jogos corporais se iniciam e nessa relação corpo-capoeira-musicalidade, tendo ainda como suporte outros instrumentos musicais percussivos (atabaque e pandeiro), aumenta a potência da vibração da roda, dando o devido sentido e significado ao termo "ladainha". Apesar de pandeiro, agogô, reco-reco e atabaque auxiliarem na potência dos jogos corporais na capoeira, quem definirá o fim da roda será o berimbau, em um ato ritualesco e ancestral de iniciar e finalizar o jogo/dança/luta na arte da capoeiragem.

A ladainha é a primeira parte do canto onde, após o brado do termo “iêe!", passa-se à narrativa de um acontecimento, cuja motivação pode vir de um pedido de auxílio, de uma proposta de luta, de uma declaração de amor, de tristeza, etc. Normalmente é executada por uma pessoa que detenha respeitabilidade na roda. Esta pessoa tanto pode estar posicionada na orquestra tocando um dos três berimbaus, como um dos capoeiristas que deverão iniciar o jogo, assim que chegar o momento oportuno.

este brado de "iê!" pode ser usado na roda, de maneira forte e prolongada ("iêêê...") quando antecede o canto0 da ladainha, ou ainda forte e curto ("iê!") quando para interromper e/ou finalizar a roda. Durante os treinamentos, fora da roda propriamente dita, serve 
para indicar a necessidade de que todos parem e voltem suas atenções para aquele que estiver conduzindo alguma atividade, pois trata-se de necessidade de manifestar algum acontecimento para qual todos devem estar atentos [ARAújo, 2015, p. 99-100].

Vale dizer que o canto da capoeira e dos jogos corporais, em sua construção ritualesca, traz, além da ladainha, a chula e o corrido. A chula corresponde à segunda parte do canto após a ladainha e tem em sua configuração rítmica e do jogo ritual o momento de saudações, sejam elas sagradas, a mestres, a convidados, aos capoeiristas do grupo e àqueles que visitam o grupo. O "canto corrido", ou apenas a expressão "corrido", apresenta-se "como a maioria dos cantos da capoeira, podendo variar no número de trovas, que (tanto) pode ser de uma estrofe" (Araújo, 2015, p. 101).

Nos cenários de organização e de expressão cultural nos quais tem predominância a capoeira e os jogos corporais, podemos perceber que ambas as práticas se dão em contextos de formação e de cultura, seja no campo formal ou não formal e em um tempo/espaço disponível para o desenvolvimento pessoal e social de quem as pratica ou vivencia. Ambas trazem em suas essências elementos sociológicos, antropológicos, pedagógicos, estéticos, eróticos, artísticos, lúdicos e formativos, que constituem a tessitura para um fazer/viver que transcende o olhar daqueles que se debruçam em compreender e interpretar as nuances e singularidades que a capoeira e os jogos corporais detêm.

É preciso um olhar criterioso para tentar compreender essas expressões e vibrações culturais enquanto campo de estudo, de vivência e de prática, fecundo de experiências formativas, que em sua maioria vão materializar-se no tempo disponível, portanto no tempo de lazer. Lazer este que, pensado em uma perspectiva crítica, requer mediação e intervenção. Mediação no sentido de contribuir para pensarmos formas de construir ações que elevem a compreensão da capoeira e dos jogos corporais para além das visões simplistas, preconceituosas, e como epifenômenos sobre tais expressões e vibrações das culturas populares. E intervenção como possibilidade de se constituir um lazer possível de empoderamento das matrizes africanas em sua história e memória, bem como conscientizar aqueles sujeitos que ainda folclorizam a cultura do outro, tornando-a episódica e efêmera.

Nesses termos, pensar a intervenção no campo do lazer, com a capoeira e os jogos corporais, passa por uma visão de mundo que tem em seu escopo principal a emancipação humana. Requer um aprender diário. O cinema, a arte, as exposições, as aulas de capoeira, os jogos corporais, 
a poesia, a luta, o jogo, a dança, a festa, devem todos compor um grande mosaico de troca de saberes e de tecnologias sociais que se possam constituir parte da vida cotidiana das pessoas, em que a escola da vida e a escola formal venham configurar-se em uma grande teia entretecida para a garantia do acesso aos bens culturais do lazer, enquanto vivência e prática diária. Esse é o nosso grande desafio pelo/no e com o lazer.

Pensando na multiplicidade de experiências com a capoeira e na linha de entendê-la como uma prática corporal, um interesse cultural do lazer, agora, como ação final, trabalharemos com a construção de modos de experimentação com essa atividade no lazer.

\section{A roda}

Tendo em vista o grupo participante da atividade, deve-se, em um primeiro momento, pensar a roda e suas formas de constituição. Assim, antes de formá-la, o condutor da atividade, o mestre, pode:

- Chamar o grupo e lançar as questões: Como podemos organizar a roda de capoeira? Qual será a distribuição dos participantes nesse espaço? Qual a posição ideal para os instrumentos? Que sentido e significado tem a roda no ambiente da capoeira?

- Feito o debate inicial, o mestre pode chamar a montagem da roda e assim desenvolver toda a dinâmica da atividade, no tempo/espaço ideal, e, ao final das atividades, iniciar um novo debate, que permita avaliar as questões iniciais e ainda apontar outras perguntas essenciais: Qual o valor da roda para o desenvolvimento das atividades? Como o grupo se sentiu ao construir o processo de jogo da capoeira de forma coletiva? $\mathrm{O}$ que diferencia a construção individual da construção coletiva? O que significa pertencer a determinado grupo?

- Após refletir sobre o sentido e o significado da roda e de grupo, o mestre pode lançar novas reflexões ao grupo sobre o instituinte e o instituído na roda de capoeira e nas relações sociais, a exemplo: $\mathrm{O}$ que significa dominar o jogo de capoeira na roda? Quem gostaria de ser dominado? Quem gostaria de ser o dominador? Por que querer dominar ou ser dominado? Quem nos domina na sociedade? Por que nos deixamos dominar? O que é ser oprimido? O que é ser opressor? O que devemos fazer para mudar esse processo de dominação, tanto na roda de capoeira como na sociedade em geral? Qual é o papel do líder (mestre) no caso da capoeira? 


\section{A música e os instrumentos}

- Em um primeiro momento, o grupo faz a montagem da roda tomando como base os debates iniciais. Com isso, a música e seus instrumentos passam a ganhar centralidade na atividade. Durante a roda, o mestre e os participantes que tocam os instrumentos podem promover a variação de ritmo e de velocidade de execução do toque, de maneira proposital, sem anunciar ao grupo, para que ao final, em uma conversa, seja debatido sobre o papel da música na roda, como ela pode ser tocada e as diferenças nos movimentos em virtude das variações.

- Na mesma linha, todo o grupo de capoeiras pode, em determinado momento, ser chamado a experimentar o toque dos instrumentos, para assim reconhecer sua estrutura, a composição de seus materiais, as possibilidades rítmicas que cada um oferece, e até mesmo explorar as formas de construção de cada um.

- Seguindo essa lógica, com o auxílio do mestre, o grupo pode lançar novas questões: Qual a importância dos instrumentos musicais na roda de capoeira? Por que a música e os instrumentos musicais são tão importantes para a roda? Qual a origem das músicas e dos instrumentos musicais que compõem o conjunto da obra na capoeira?

\section{A ginga}

Elemento essencial da atividade capoeira, a ginga pode ser pensada para além da demonstração e da repetição de seus gestos. Assim, podemos pensar em:

- Dividir os participantes em duplas e, com tempo determinado, deixar que experimentem, de acordo com suas experiências e saberes, aquilo que concebem como o movimento da ginga. Na dupla, enquanto um executa, o outro acompanha e analisa para, depois, conversarem sobre aquilo que cada um viu e como pensa o movimento. Nessa linha, pode-se, em tempos marcados, promover uma mudança de duplas no intuito de permitir a construção de vivências e de diferentes leituras sobre o movimento.

- Passado esse tempo, a roda pode ser composta e as mesmas duplas iniciais, de forma espontânea, põem-se a executar a 
ginga dentro do círculo. Após todo o grupo ter vivido a experiência, pode-se promover um debate sobre a ginga, sua execução e papel na roda. Outra possibilidade acerca da ginga é provocar uma conversa sobre como o movimento de corpo pode equilibrar e desequilibrar o jogo, perguntando: $\mathrm{O}$ que me faz equilibrar no jogo? O que devo fazer se eu perder o equilíbrio? Por que tenho que gingar olhando no olho do meu oponente e não para os movimentos dos seus pés? No meu dia a dia, como devo me movimentar para manter o equilíbrio nas tarefas que desenvolvo? O que me desequilibra na vida cotidiana?

\section{A capoeira e sua construção histórica}

- Em determinado dia, previamente marcado, em vez de já se iniciar com as atividades, a roda pode, em um primeiro momento, trazer para visualização e debate materiais gráficos diversos que tenham a capoeira como base, tais como: fotografias, pinturas, desenhos, caricaturas. Assim, ao mesmo tempo em que se trabalha o papel da arte, também se dá aos presentes a possibilidade de contato com fontes diferentes de imagens e, ainda, pode-se tentar analisar as formas com que a capoeira é tratada.

- Essa mesma dinâmica pode ser feita com o recurso de músicas, filmes (curtas ou longas e documentários), sempre começando com a exibição, mas também trazendo o debate e a vivência. Vale aqui reconhecer que esse exemplo visa trabalhar a formação cultural e a aproximação com linguagens artísticas na roda, com a capoeira no centro de tudo.

- Outra possibilidade é convidar o grupo para visitar museus, escolas de capoeiras, visita a exposições sobre o tema, ir ao cinema com o grupo para assistir a filmes relacionados à identidade cultural, racismo, empoderamento, africanidade, entre outros temas que possam emergir coletivamente no grupo.

- O mestre, com o grupo, pode construir um calendário anual de ações ligadas às aulas de capoeira e suas interfaces, com os interesses culturais do lazer, tais como: festivais, encontros, roda de conversas, oficinas de construção de instrumentos musicais (berimbau, pandeiro, caxixi etc.), oficinas 
percussivas, oficinas de samba de roda, conversas com mestres antigos portadores de saberes e fazeres da cultura popular (os griôs), esquetes teatrais, oficina culinária (gastronomia afro-brasileira), sarau afro-brasileiro (poesia, rap, repente, literatura de cordel e literatura clássica), entre outras ações que o grupo considerar pertinentes e possíveis de se materializarem no tempo/espaço de lazer.

Enfim, buscamos aqui promover uma leitura sobre a capoeira em suas bases históricas e sociais, para ainda a vincular a possibilidades de lazer, como atividade nesse tempo, além da tentativa de construirmos exemplos, sabendo que eles são apenas situações pontuais, mas que muitas outras podem ser elaboradas e vivenciadas, sempre tendo por base as condições concretas que cada realidade apresenta. No entanto, interessou-nos, sobretudo, mostrar e reconhecer o valor social e educativo que a capoeira assume nos contextos da sociedade brasileira.

\section{Referências}

Araújo, R. C. (Mestra Janja). É preta, Kalunga: a capoeira angola como prática política entre os baianos: anos 80-90. Rio de Janeiro: MC\&G, 2015.

Camargo, L. O. L. O que é lazer. São Paulo: Brasiliense, 1986.

Carvalho, J. M. Os bestializados: o Rio de Janeiro e a República que não foi. 3. ed. São Paulo: Companhia das Letras, 2009.

Castro Júnior, L. V. Campos de visibilidade da capoeira baiana: as festas populares, as escolas de capoeira, o cinema e a arte (1955-1985). Brasília, DF: Ministério do Esporte, 2010. ( $1^{\circ}$ Prêmio Brasil de Esporte e Lazer de Inclusão Social).

Dumazedier, J. Valores e conteúdos culturais do lazer. São Paulo: SESC, 1980. Carvalho, J. M. Lazer e cultura popular. 3. ed. São Paulo: Perspectiva, 2001. Koselleck, R. Uma história dos conceitos: problemas teóricos e práticos. Revista Estudos Históricos, Rio de Janeiro, v. 5, n. 10, p. 134-146, jul./dez. 1992.

Macedo, R. S. Pesquisar a experiência: compreender/mediar saberes experienciais. 1. ed. Curitiba: CRV, 2015.

Marcellino, N. C. Estudos do lazer: uma introdução. Campinas: Autores Associados, 1996. 
Melo, V. A. Dicionário do esporte no Brasil: do século XIX ao início do século xx. Campinas: Autores Associados; Rio de Janeiro: UFRJ, Centro de Ciências da Saúde, 2007.

Melo, V. A. Esporte e lazer: conceitos. Rio de Janeiro: Apicuri, 2010.

Melo, V. A.; Alves Junior, E. D. Introdução ao lazer. São Paulo: Manole, 2003.

Oliverra, J. P. Pelas ruas da Bahia: criminalidade e poder no universo dos capoeiras na Bahia Republicana (1912-1937). 2004. Dissertação (Mestrado em História) - Faculdade de Filosofia e Ciências Humanas, Universidade Federal da Bahia, Salvador, 2004.

Rocha Junior, C. P. Esporte e modernidade: uma análise comparada da experiência esportiva no Rio de Janeiro e na Bahia nos anos finais do século XIX e iniciais do século XX. 2011. Tese (Doutorado em História Comparada) - Instituto de História, Universidade Federal do Rio de Janeiro, Rio de Janeiro, 2011.

Rocha Junior, C. P.; Pinto Junior, F. D. Cidadania e lazer a partir do Programa Escola Aberta. Revista ARQuivos em Movimento, Rio de Janeiro, v. 7, n. 1, p. 104-115, jan./jun. 2011.

SAntos, R. A. Educação, lazer e cultura juvenil: investigando práticas de lazer em cenários de organização e expressão de culturas juvenis urbanas contemporâneas e suas relações com os "atos de currículo". 2011. Tese (Dourado em Educação) - Faculdade de Educação, Universidade Federal da Bahia, Salvador, 2011. 


\title{
FESTAS, MODOS DE VIDA E PATRIMÔNIO CULTURAL: EXPERIÊNCIAS DE LAZER NOS RITUAIS DO TEMPO E DO TERRITÓRIO
}

\author{
Joyce Kimarce do Carmo Pereira \\ Karla Tereza Ocelli Costa \\ Sônia Cristina de Assis \\ José Alfredo Oliveira Debortoli
}

Neste texto buscamos compartilhar alguns estudos, temas e desafios que temos enfrentado no âmbito da pós-graduação em estudos do lazer ${ }^{1}$. Em uma perspectiva etnográfica, propomos compreender os contextos coletivos nos quais as pessoas tecem suas relações, considerando que em suas corporalidades revelam-se sentidos e processos de organização, estruturando como vivem e significam o tempo e o território comum em que habitam. Temos observado que os sentidos do lazer emergem do envolvimento com o território, entrelaçando experiências singulares de produção cotidiana da vida.

1 O grupo de pesquisa Núcleo de Estudos sobre Aprendizagem na Prática Social (NAPrática), coordenado pelos professores José Alfredo Oliveira Debortoli, da Escola de Educação Física, Fisioterapia e Terapia Ocupacional da Universidade Federal de Minas Gerais (EEFFTO/UFMG), e Eliene Lopes de Faria, do Colégio Técnico (Coltec/UFMG), tem como objetivo realizar estudos sobre a aprendizagem em diferentes práticas socioculturais, enfatizando a relação educação, cultura, corpo e arte. A aproximação de pessoas e grupos sociais, em seus contextos, tem nos provocado a constituir um quadro teórico que possibilite descrever/analisar/compreender experiências culturais de maneira articulada a questões pertinentes ao campo da educação e do lazer, abrindo caminho para produções compartilhadas de conhecimento no processo de participação coletiva na vida social. 
Assim, estamos atentos às relações e aos sentidos que coletivamente as pessoas denotam em seus engajamentos. Buscamos reconhecer experiências em que, nos processos de participação comunitária, potencializam a consciência, a construção e a transformação de suas realidades. Entendemos que as práticas sociais revelam uma riqueza de experiências culturais, nas quais se constituem as pessoas.

Aproximando-nos do sentido proposto por Manuel Cuenca Cabeza (2007), interessa-nos problematizar os modos "como vivemos juntos", observando os processos singulares e diversos de produção humana e social. Neste texto, enfatizamos as festas no âmbito de suas histórias e rituais, fluindo em uma riqueza expressiva de práticas sociais fundadas no tempo e no território, que se expressam em músicas, danças, ritmos, técnicas corporais, artefatos, celebrações e narrativas.

Com esse sentido, as festas estabelecem fronteiras entre a arte e a vida, sendo a própria vida apresentada com elementos característicos da representação. Por meio do acontecimento das festas buscamos realçar o lazer não por uma definição dada a priori, mas como uma concepção, um princípio. Uma lente que tem nos possibilitado focar, aproximar e nos envolver com processos de produção da vida que vão além de nossa condição humana instrumental e objetiva, em direção a processos sociais pautados em ricos caminhos de expressão e de partilha ética e estética.

\section{Os saberes das Festas de Reinado e Reisado}

A palavra festa, em sua etimologia em latim, deriva de festum, que designa dias dedicados a festejos religiosos. Mikhail Bakhtin (1999), inspirado na obra de Rabelais, mostra como as festas pertencentes à esfera particular da vida cotidiana são um sistema primordial e marcante da civilização humana. Além de serem consideradas um produto das condições e finalidades do trabalho coletivo, as festividades se expressam como conteúdo essencial e profundo de uma concepção de mundo.

Dessa perspectiva, em um de nossos percursos de pesquisa, compartilhamos uma experiência do festejar tendo como contexto a Irmandade Folia de Reis São Francisco de Assis (Assis, 2016) e a Irmandade do Rosário de São Benedito ${ }^{2}$, ambas situadas na cidade de Carmo do Cajuru,

2 Pós-doutorado de Sônia Cristina de Assis, em andamento, no Programa de Pós-Graduação em Estudos do Lazer na EEFFTO/UFMG, intitulado Música e dança no Reinado Mineiro e suas contribuições como repertório para educação musical. 
Minas Gerais. Antes de apresentarmos essas irmandades, expomos as palavras daqueles que dão movimento e vida a essas festas, no caso a fala do capitão da Guarda de Congo de São Benedito: "Festa é uma comemoração de liberdade, um grito de liberdade. Ela traduz uma coisa alegre, representa um conteúdo bom. A festa, em si, traz todo o ato festivo do Reinado".

Pautados no diálogo entre os campos do lazer, da música e da antropologia, enfatizamos o ritual da festa destacando a centralidade nas habilidades, nos cantos e nos instrumentos musicais. Dentro das comunidades festivas, especificamente na esfera do Reinado e do Reisado, percebemos um local familiar em que cultura, tradições e hábitos são cultivados, experimentados e compartilhados. Nesse território, as raízes prevalecem considerando histórias, músicas, danças e materialidades, que são elementos implícitos e significativos. Na busca desse viver junto, em comunidade, estabelecem-se a troca e a segurança, que atendem às necessidades afetivas e sociais, viabilizando a força pela vida. A manutenção dessas práticas acontece em virtude do comprometimento, com seus mantenedores sendo representados por mãe, pai, avô, avó, padrinho, madrinha, tio, tia e primos. O papel dos condutores está em disponibilizar os segredos e as histórias do reino, que constituem um conjunto de saberes que são apreendidos desde o nascimento, para aqueles que se fizerem escolhidos.

A aprendizagem de tais saberes é um ato importante dentro dessas comunidades, exigindo o compromisso sagrado com a sua continuidade. É importante ressaltar que a história do Reisado ${ }^{3}$ tem fortes ligações com a história do Reinado ${ }^{4}$. Ambos trazem em comum uma afirmação da identidade negra de resistência cultural, de sobrevivência e conquistas de um povo reprimido e violentado pela escravatura, que utilizou de estratégias de preservação para dar continuidade a suas práticas culturais e religiosas.

$\mathrm{Na}$ Festa de Reisado da Irmandade Folia de Reis São Francisco de Assis comemora-se o nascimento do menino Jesus, sendo as ruas da cidade de Carmo do Cajuru o lugar dos encontros e das jornadas, entrelaçadas por experiências e vivências musicais (Assıs, 2016). No Reinado, comemora-se a Festa de Nossa Senhora do Rosário e, com uma linguagem própria de se expressar na sociedade, utiliza-se também a música, a dança e o

3 Reisado, Folia de Reis ou Festa de Santos Reis é uma manifestação cultural religiosa do ciclo natalino, a partir do dia 25 de dezembro até o dia 6 de janeiro.

4 O Reinado de Nossa Senhora do Rosário, manifestação cultural e religiosa afro-brasileira, é composto de reis, rainhas e seus respectivos ternos. 
canto. É composto de ternos de Congo, Moçambique, Marujo e Catopés, cada um com expressividade própria de narrativa. A história de vida do Reinado se garante pela participação de crianças e jovens que desde cedo se movem ao som do ritmo das caixas, reco-recos, pandeiros, patangomes e gungas ${ }^{5}$.

Saber tocar, dançar e cantar, nessas práticas, perpassa por um envolvimento e participação no grupo. Jean Lave (2015), por meio dos estudos sobre a teoria da aprendizagem situada, tem nos possibilitado identificar os processos de aprendizado utilizado nessas práticas sociais. De início, explicitamos que no âmbito da prática musical e ritual das festas dessas irmandades, para que a aprendizagem aconteça, é essencial que se aprimorem a escuta ativa, o ver e imitar os mais experientes. Os envolvidos na Folia de Reis São Francisco de Assis ou no Reinado de São Benedito, sendo eles instrumentistas, cantores ou dançarinos, desenvolvem habilidades participando, dialogando, observando, escutando e executando a performance musical. Como destaca Ingold (2010), uma redescoberta do conhecimento que não está fora das pessoas, mas que se desponta pelas habilidades e inserção no ambiente. Aprender perpassa pelo ato imitativo de copiar aquele que orienta, que possui maior habilidade e experiência. Diferentemente, segundo Ingold (2010, p. 21), "de uma transcrição automática de conteúdo mental de uma cabeça para outra, em vez disso, uma questão de seguir o que as outras pessoas fazem".

Para compreendermos esses processos, focamos no campo da apresentação musical. Na Folia de Reis São Francisco de Assis existem três acordeões que são considerados guias na prática musical, sendo eles de 8 , 48 e 120 baixos. $\mathrm{O}$ acordeão de oito baixos é tocado por um folião que acompanha a folia desde criança. Segundo ele, o acordeão de oito baixos foi introduzido na irmandade por seu avô e depois passou para seu pai. A aprendizagem do instrumento aconteceu em casa, com os familiares, como também na prática musical da Folia de Reis. O engajamento desse folião na folia com o acordeão lhe possibilitou ser o responsável por mediar a prática musical durante as jornadas. $\mathrm{O}$ tocador de oito baixos é o encarregado de iniciar e finalizar as músicas da Folia de Reis, uma tarefa difícil nesse instrumento, pois, ao abrir o fole soa uma nota e ao

5 Patangome: instrumento de percussão feito de lata redonda e com esferas dentro. Gungas: cilindros de folhas de zinco ou de latas de conservas, presos em uma tira de couro e amarrados nas pernas do dançarino. 
fechar, outra. O tempo de experiência na folia permite ainda que foliões mais experientes auxiliem outros inexperientes durante a performance, $\mathrm{e}$ assim a prática de aprendizagem nesse contexto, além de promover conhecimento, fortalece o grupo musicalmente.

A música nos territórios de Reinado e Reisado torna-se indissociável da concepção religiosa, filosófica, cosmológica e educacional. $\mathrm{Na}$ Irmandade de São Benedito, segundo os capitães, ela é utilizada para educar as pessoas. Para entendermos esse processo, destacamos o papel dos capitães das guardas. Para tornar-se capitão, é imprescindível uma aquisição de experiências, como ser conhecedor dos fundamentos do Reinado, saber conduzir a guarda, conhecer os ritos e cantos. Na hierarquia do Reinado, depois dos reis e rainhas, os capitães experientes são aqueles que detêm os saberes e, em meio ao ritual, criam músicas como um modo de educar. Na Guarda de Congo da Irmandade de São Benedito, o capitão explica como a aprendizagem, por meio dos versos cantados, surge no momento da performance musical. Quando algo errado está acontecendo dentro da guarda, ou em um ritual específico, uma música é enviada pelo capitão para comunicar os congadeiros. Portanto, se no Reinado de São Benedito um congadeiro não está cumprindo corretamente o ritual, o capitão cantará um verso notificando-o. Um bom congadeiro precisa seguir todos os ritos quando se chega à casa de um rei. No ritual há uma preparação, tem que saber chegar, saudar e coroar. Se algum congadeiro não estiver participando adequadamente do ritual, o capitão canta um verso assim:

Toma cuidado menino

Com aquilo que está fazendo

Pois eu vou contar pro seu pai

Seu avô vai ficar sabendo

Capitão: Tudo gira, nós fazemos tudo, mas quando fala do nosso avô que é a margem principal, todo mundo se curva diante dessa situação. Quando se fala do avô, aquele que não está errado vai procurar quem está errado. No mínimo ele irá consertar a roupa dele.

O aprender está imbricado de ancestralidade, de performance ritualística, de ritos sagrados, ou seja, de uma estrutura organizacional complexa. Podemos perceber que os versos cantados, tidos como veículos de comunicação, dentro das guardas educam e alertam seus integrantes. Esses cantos compõem uma tessitura discursiva aliada ao som, ao ritmo 
do corpo e ao gesto, unindo harmonicamente música e dança. Saber cantar e o que cantar, segundo Leda Martins (1997), produz a eficácia no canto, na voz, nos gestos e na produção de sentido. Tornar-se um integrante das guardas de Moçambique, Catopés ou Congado é um aprendizado que perpassa por uma preparação ao longo da vida, uma busca de aprimoramento no âmbito relacional, espiritual e emocional. É recriar um saber filosófico banto, ligando presente e passado em conexão com a ancestralidade e o sagrado.

\section{As festas como processo identitário ${ }^{6}$}

Tendo presente o debate antropológico em torno do termo identidade, é fundamental concebê-lo em uma perspectiva complexa ${ }^{7}$, como sistema multidimensional que integra e articula várias dimensões do ser humano, de uma forma dinâmica, na tensão dialógica entre conservação e transformação. A luta política pela identidade ocorre em uma zona de tensão pela busca de conservação de uma ancestralidade. Esse olhar torna-se relevante ao romper com visões lineares e homogêneas que tentam fixar a identidade na "mesmidade".

Para Sodré (1999), a identidade de um sujeito ou de um grupo classifica sua ação em uma situação interativa, permitindo-lhe assim agir como ator social. Ela não é "um caminho pronto para se andar, mas um caminho que surge com e ao se andar" (Sodré, 1999, p. 37). Segundo esse autor, o pertencimento é "recíproca escuta na diferença", e a identificação é o "comum-pertencer" dinâmico, que mobiliza pulsões, afetos, escolhas. É uma identidade que não busca ser igual, mas igualdade, acolhendo todas as diferenças; uma identidade que afirma a singularidade não como forma de comparação; uma identidade que ao se afirmar foca na alteridade, na "efetiva partilha do território" (Sodré, 1999, p. 262). Maturana et

6 Pesquisas de mestrado e de doutorado Karla Tereza Ocelli Costa $(2013,2017)$ buscando compreender as festas dentro de duas comunidades quilombolas mineiras, Arturos/Contagem e Carrapatos da Tabatinga/Bom Despacho, realizadas no Programa de Pós-Graduação em Estudos do Lazer na EEFFTO/UFMG.

7 Complexidade, segundo Morin (2013), como princípio dialógico que propõe a convivência entre antagonismos e oposições.

8 Mesmidade, conforme Sodré (1999), valendo-se do conceito do filósofo francês Paul Ricoeur, refere-se a "coisas idênticas". 
al. (2014) também se referem a essa dialética entre conservação e transformação ao conceberem a identidade como um processo dinâmico que se produz em um sistema vivo, no qual as relações acontecem.

Para Zerbo (1982), a construção da identidade é importante para o sujeito, visto que será apoiado nela que ele se sentirá o agente de sua história. O autor afirma que não se pode amar aquilo que não se conhece. Só é possível formar uma identidade com aquilo que se conhece. Também, para Munanga (2002), a identidade cultural se constrói com base na tomada de consciência das diferenças provinda das particularidades históricas, culturais, religiosas, sociais, regionais etc. Delineiam-se assim, no Brasil, diversos processos de identidade cultural revelando certo pluralismo entre negros, brancos etc. Todos tomados como sujeitos históricos e culturais, e não como sujeitos biológicos ou raciais.

A identidade não é assim fechada, imune ao contato, alheia aos movimentos das relações cotidianas. Ela é plural, sendo afetada por essas relações. Constituí-la pressupõe um reconhecer-se tomando como base seus pares, o outro e o que emerge dessas relações. No que diz respeito às populações tradicionais, é fundamental que se compreendam as implicações das práticas culturais vivenciadas no processo de construção de suas identidades (Costa, 2013). A afirmação de uma identidade étnica não perpassa, como visto, pelos caminhos dos critérios biológicos, raciais, culturais e linguísticos, mas sim, como afirma Barth (1998), pela noção de pertencimento mediante afiliação e exclusão no que diz respeito a "fronteiras contrastivas". A relação entre pertencimento e diferenciação sempre medeia os processos identitários.

Para Maroun (2013), as identidades se constroem com base em processo plural e permanente, no contato com o outro, na troca, no conflito e no diálogo. A autora ainda afirma que a identidade negra vai além dos códigos de uma identidade singular, mas "contextualiza o caráter coletivo de pertencimento e representação do indivíduo a esse grupo" (MAROUN, 2013, p. 49). A identidade coletiva quilombola tem marcada no corpo as dificuldades e os desafios enfrentados pelo grupo, o que expressa uma história secular de marginalização e de forte ligação com a terra, símbolo de identidade coletiva, resistência ao sistema opressor e fonte de cultivo de suas tradições.

A construção da identidade étnica perpassa pela reflexão do que essa individualidade representa em um país marcado pelas diferenças sociais, como é o caso do Brasil, e também pela discussão de processos 
que engendram, naturalizam e imobilizam. Jogar luz sobre o que é aparentemente posto nos modos de ser, ver, pensar, vivenciar e interagir é importante para compreendermos os processos que naturalizam as desigualdades, não como algo dado, biológico, mas pertencente a uma rede social e culturalmente construída. Portanto, refletir sobre tais processos e sobre a participação neles no âmbito das práticas corporais também é fazer discussão política (Costa, 2013).

Para compreendermos o movimento de constituição identitária desses sujeitos, é fundamental a percepção atenta das estratégias elaboradas por e na construção e reconstrução do seu processo identitário e, consequentemente, de sua sobrevivência coletiva. Nas comunidades congadeiras quilombolas, a família é, ainda hoje, o primeiro local de aprendizado. A criança tem nos pais e na lembrança dos antepassados o espelho no qual se mirar. A educação das crianças apresenta-se como um dos pontos mais profícuos para o entendimento da estrutura social dessas comunidades, pois em casa ela aprende desde pequenina a linguagem do corpo, por intermédio das danças do Congado, e na escola ela deve aprender a "disciplinar o seu corpo". Mesmo entendendo a dificuldade de se prever o resultado dessa duplicidade vivida, é no confronto entre a cultura oficial aprendida na escola e a cultura repassada por seus antepassados que a criança vai formando-se como sujeito. Isso nos possibilitou observar que as crianças vivenciam nas festas a reatualização da presença de seus antepassados. Nas brincadeiras do cotidiano, a figura do mais velho como referência está sempre presente, seja ensinando uma cantiga, seja contando uma história. E essa presença não é vista como uma intromissão, mas como peça fundamental do jogo.

Para entender em que medida a Festa do Reinado de Nossa Senhora do Rosário e o participar dela potencializam a continuidade de suas raízes culturais, suas implicações para a afirmação positiva da identidade racial e para a vinculação e o pertencimento à comunidade, é preciso estar atento às sutilezas do passado histórico do povo negro e a como foram construídos, tijolo atijolo, os alicerces de sua resistência, compreendendo qual significado os integrantes das comunidades congadeiras dão às suas festas e quais relações estabelecem com sua identidade étnica.

$\mathrm{O}$ aniquilamento da memória cultural foi um dos mais perversos mecanismos de opressão impostos ao escravo, pois um homem sem referência no passado dificilmente se sente preparado para olhar o futuro. As matrizes que possibilitam dar ao homem do presente ferramentas para 
recriar e enriquecer sua identidade, orientando-o no mundo, estão depositadas na vivência de seus antepassados. E assim a consciência de um passado de submissão estimula os congadeiros a lutarem contra a opressão atual. A resistência e a liberdade de seus ancestrais, comemoradas nas festas, são suportes que os fortalecem na luta diária para fazer valer seus direitos. Reativando a memória combativa de seus antepassados por meio de seus cantos, eles se reatualizam como atores de sua própria história, respondendo com força às estocadas do sistema opressor.

Segundo Gomes e Pereira (2000), o Congado é uma festa, mas também um desafio. Chama para reza e para luta. Ser dançante do Congado é disponibilizar seu corpo para que nele ocorram as forças da ancestralidade. Os corpos que se movem dançando o Congado resgatam a caminhada dos negros, os fragmentos da história material e psicológica dos escravos. A africanidade ali se faz presente: o dançar e o cantar tornam-se uma oração.

A Festa do Rosário abre um intervalo no tempo do trabalho cotidiano e instaura um espaço-tempo mítico no qual para sempre vivem os ancestrais. O festejar do Reinado do Rosário deixa de ser um simples representar, tornando-se um meio de afirmar o ser. Essa tradição, herdada e reelaborada cotidianamente, é o anteparo e a força promotora de sua própria identidade. Para Gomes e Pereira (2000), o homem religioso que festeja retorna às suas origens, reencontra sua plenitude. Alimentando-se da fonte primordial, agrega em si forças de seus ancestrais e, quando retorna ao tempo profano, reintegra-se fortalecido ao cotidiano. Quando essa força se esvanece, uma nova festa acontece, permitindo-lhe munir-se de novas energias.

Cada membro da comunidade é um elo na corrente de Maria. A solidez dessa corrente demonstra as resistências religiosas dos negros, tornando-se o santuário sagrado dos anseios de sua gente. $\mathrm{O}$ reinadeiro é filho da África, herdeiro da Terra-Mãe, que participando da festa se sente reconduzido a ela, por intermédio da cultura de seus ancestrais. Ao dançar e cantar para a Mãe do Rosário, os reinadeiros se fazem filhos e irmãos na fé. Os movimentos, a palavra, o toque dos tambores, o som das gungas os aproximam de Deus. Nas irmandades de Reinado, cada um se sente partícipe do grupo porque dança junto, reza junto, cumpre cada ritual com disciplina, valorizando cada detalhe do vestuário, dos instrumentos, da dança, do canto. A festa para os reinadeiros é a exteriorização do sagrado. 
O modo de ser dos reinadeiros se expressa, fundamentalmente, nas manifestações artístico-culturais e nas celebrações do sagrado que a comunidade preserva e recria. Essa festa para os reinadeiros é "fator de aliança e elemento agregador da comunidade" (Gomes; Pereira, 2000, p. 215). Assim a análise do calendário festivo dos reinadeiros nos possibilita perceber a dimensão da importância dessas festas para a comunidade, principalmente a do Reinado de Nossa Senhora do Rosário, na qual a religiosidade da comunidade transborda e seus integrantes se transmutam em filhos do Rosário.

\section{Patrimônio: "A comunidade é a melhor guardiã de seu patrimônio" ${ }^{9}$}

Desde os primórdios dos tempos, o patrimônio está alicerçado na ideia de bens materiais familiares transmitidos como heranças para seus descendentes. Assim, os bens produzidos pelos seres humanos, além de perdurarem com o passar dos anos, acabaram transformando-se em "elementos venerados e valorizados" (BALlarT, 1997, p. 78). Segundo essa perspectiva, segundo Ballart (1997), por meio desses objetos é possível compreender os costumes, as crenças e a cultura dos sujeitos. Nesse ínterim, de maneira geral, patrimônio nada mais é que um "conjunto de objetos que uma sociedade herda de seus descendentes para possuí-los efetivamente e fazer uso que mais lhes convenha" (BALLART, 1997, p. 78).

Entretanto, para além desse entendimento, o patrimônio constitui-se de um elemento conformador da identidade dos povos aliado à dinâmica relacional da vida em sociedade. Dessa forma, o patrimônio não é composto somente dos bens do passado, ele é o resultado de uma "dialética entre o homem e seu meio, entre a comunidade e seu território, ou seja, tudo que os seres humanos atribuem ao legado material e imaterial de sua nação" (MaCHado; Dias, 2009, p. 2).

Tomando como base esse princípio, o patrimônio é um elemento no qual a sociedade se identifica e se reconhece, uma vez que ele é detentor das memórias, das histórias, dos modos de vida e da identidade

9 Pesquisa de mestrado de Joyce Kimarce do Carmo Pereira, no contexto do Programa de Pós-Graduação em Estudos do Lazer na EEFFTO/UFMG, intitulada Entre festejos e ofícios: um olhar acerca das manifestações culturais do Toque dos Sinos de São João del-Rei/Minas Gerais. 
sociocultural. Esse processo culmina na valorização dos sujeitos em perpetuar essas práticas, agregando ao patrimônio tanto elementos materiais quanto imateriais (MACHADO; DiAs, 2009). Conforme a Organização das Nações Unidas para a Educação, a Ciência e a Cultura (Unesco) (2006) ${ }^{10}$, o patrimônio é constituído das: "Práticas, representações, expressões, conhecimentos e técnicas - com os instrumentos, objetos, artefatos e lugares culturais que lhe são associados - que as comunidades, os grupos e, em alguns casos, os indivíduos reconhecem como parte integrante de seu patrimônio cultural".

Diante desse cenário, o patrimônio, ao adquirir um valor social, cultural e identitário para a humanidade, assume o que Rodrigues (2003) afirma acerca da identidade coletiva por trás desse processo, em que o patrimônio contribui para trazer o "sentido de grupo" à vida dos seres humanos. A perspectiva da coletividade, segundo Rodrigues (2003, p. 17), "permite aos homens lembrar e ampliar o sentimento de pertencer a um mesmo espaço, de partilhar uma mesma cultura e desenvolver a percepção de um conjunto de elementos comuns". Ao atribuir esse sentido de coletividade, o patrimônio tornou-se alvo de um processo de institucionalização no contexto das políticas públicas. Assim, a política voltada para a preservação dos bens materiais e imateriais sugere uma "escolha oficial", em que essa ação, ao mesmo tempo em que "envolve exclusões, também significa algo construído para ser uma representação do passado histórico e cultural de uma sociedade" (Rodrigues, 2003, p. 16).

Cabe destacar que muitas vezes essa escolha contempla objetos e práticas não reconhecidos socialmente pelas comunidades, o que faz as comunidades perderem o sentido, pelo fato de a nomeação não estar historicamente contextualizada com o que realmente valorizam como sendo parte de seu patrimônio. Essa "exclusão" muitas vezes permeia o processo de patrimonialização, tanto material como imaterial, denotando assim o paradoxo do patrimônio apontado por Rodrigues (2003, p. 22): "o poder público, que pretende a valorização dos bens como mercadores culturais, e o de parte da sociedade, que o vê como um fator de qualidade de vida”. A autora afirma que o processo de valorização e proteção do patrimônio esteve ao longo da história aliado à preservação de bens materiais, representados sobretudo por monumentos arquitetônicos, no

10 Disponível em: <http://unesdoc.unesco.org/images/0013/001325/132540por.pdf>. Acesso em: 30 mar. 2018. 
entanto, e paralelo a isso, os bens imateriais não apresentavam o mesmo reconhecimento.

Assim, é importante ressaltar que o reconhecimento do patrimônio no cenário brasileiro, especialmente o imaterial, foi um processo lento, construído culturalmente, sendo o Instituto do Patrimônio Histórico e Artístico Nacional (IPHAN) o órgão responsável por difundir e realizar ações patrimoniais. Se as iniciativas de proteção material - do tombamento de elementos caracterizados como "ícones" da arquitetura nacional - já vinham ocorrendo desde 1920, foi somente no ano 2000, sobretudo por iniciativa do Movimento Modernista do Brasil, que se iniciou o registro dos bens tidos como imateriais, sendo normatizado pelo decreto n. 3.551, que institui o "Registro de Bens Culturais de Natureza Imaterial".

Atualmente, o patrimônio faz parte da Constituição Federal Brasileira de 1988, em seu artigo 216, o qual define: "Constituem patrimônio cultural brasileiro os bens de natureza material e imaterial, tomados individualmente ou em conjunto, portadores de referência à identidade, à ação, à memória dos diferentes grupos formadores da sociedade brasileira”.

Nesse contexto, de acordo com o IpHAN, o processo de proteção do patrimônio material se dá por meio de legislações específicas, com o instrumento legal denominado tombamento. Desse modo, no Livro do Tombo é possível inscrever bens de acordo com sua natureza, sejam elas de interesse histórico, obras de artes, sítios arqueológicos, entre outras. Já para os bens imateriais, a salvaguarda é feita por meio do instrumento legal denominado registro, possibilitando inscrever os saberes e fazeres, conhecimentos, manifestações artísticas e culturais, festas e celebrações religiosas e incontáveis práticas pertencentes ao costume das comunidades.

O registro e o tombamento dos bens são feitos na tentativa de preservar aqueles que fazem parte da história, da memória e da cultura das comunidades, a fim de promover a sua valorização e perpetuação nos mais distintos contextos brasileiros. Entretanto é importante ressaltar que essa proteção não deve ser entendida como um congelamento da cultura, pois as práticas que compõem o patrimônio, sobretudo o imaterial, "são componentes vivos de nossa cultura e, portanto, suscetíveis de mudanças" (LARAiA, 2004, p. 15).

Assim, o patrimônio, além de ser permeado de dinamismo e constantemente recriado pelos grupos, é considerado um dos elementos mais 
representativos da sociedade (DiAs, 2006). O sentimento da comunidade de pertencimento e de coletividade é um fator inerente ao patrimônio, uma vez que ele se torna um símbolo sociocultural. E é por meio dessa simbologia que as comunidades se reconhecem e se identificam com o bem.

É nesse contexto de reconhecimento, por parte das comunidades enquanto construtoras sociais e de sua própria história, bem como da cultura a qual pertencem, que o patrimônio é reconhecido, ganha vida, ganha sentido, preservando a história e a memória das comunidades. É nessa conjuntura que os "segmentos sociais e étnicos" começam a reconhecer "seus papéis de construtores da sociedade, da história e da cultura” (RodRigues, 2003, p. 17).

Para ilustrar sobre reconhecimento patrimonial, a cidade de São João del-Rei, localizada no estado de Minas Gerais, como observamos em estudo realizado sobre as festas e o ofício de sineiro, pode ser considerada um exemplo. Isso em virtude de a comunidade são-joanense ter sido protagonista no processo de patrimonialização do toque dos sinos e do ofício de sineiro. Em 2001, o IpHAN encaminhou o pedido de registro do toque dos sinos como patrimônio solicitado pela comunidade durante o evento "Inverno Cultural", da Universidade Federal de São João del-Rei (UFSJ). A comunidade almejava com essa ação, além de preservar a história e a memória dessa expressão, valorizar e difundir a importância dessa prática na comunidade. Assim, a partir daquele ano iniciou-se uma pesquisa acerca da temática, na qual o IPHAN verificou a necessidade de ampliar o registro para outras cidades, por ter detectado a presença dessa expressão cultural nos seguintes municípios mineiros: Ouro Preto, Mariana, Catas Altas, Congonhas do Campo, Diamantina, Sabará, Serro e Tiradentes. Entretanto, São João del-Rei foi escolhida como a cidade referência pelo fato de apresentar um vasto e diversificado repertório e ser a cidade de maior recorrência e perpetuação da prática.

No contexto do município de São João del-Rei, conhecido como a "terra onde os sinos falam", os toques são anunciados diariamente para a comunidade pelos sineiros. O toque dos sinos são-joanenses consiste em uma expressão sonora de sinos presentes nas torres das igrejas, em sua maioria católicas. É um modo de comunicação tradicional reiterada no cotidiano mineiro desde o período colonial fazendo-se presente ainda nos dias atuais. Basicamente, os toques em sua maioria têm influência de matriz cultural africana e são utilizados para anunciar festas religiosas, celebrações, eventos e datas litúrgicas, tais como Semana Santa, Natal, 
entre outras. Além disso, informam as horas e outros tipos de comunicações que sejam consideradas pertinentes para a comunidade.

Nesse sentido, o pedido de registro do patrimônio Toque dos Sinos, apresentado pela comunidade são-joanense, "expressa o sentimento de pertencimento a uma determinada paisagem sonora que lhes atribui uma especificidade, ao tempo que os reinsere no processo de construção da identidade" (IpHan, 2009a, p. 17).

\section{Considerações finais}

Nossa intenção central é a de compartilhar modos de ser e viver em cotidianos que nos têm provocado reflexões sobre sentidos do lazer, enfatizando a poesia de estarmos juntos, sensíveis a um mundo que requer cuidado, atenção, sensibilidade e responsabilidade. Uma noção de festa que faz convergir o brincar como experiência histórica, preenchida de sentido, narrativa e corporalidade. Os sentidos revelam e são revelados em brincadeiras, danças e versos cantados. Essa festa nos permite afirmar o lazer como prática social pautada em modos de viver enraizados em um cotidiano vivo. As experiências cotidianas têm nos trazido possibilidades de aprofundamento de questões relacionadas à diversidade das experiências culturais, que nos levam a indagar a centralidade do território como política de direito e à compreensão do lazer entrelaçada a uma diversidade de modos de produção ética e estética da vida social.

Encontramos na territorialidade festiva do Reinado e do Reisado um envolvimento solidário, convertido em musicalidade e fé, que faz emergir sentimentos comuns e modos de percepção da vida. Elaborada e reelaborada por diversas gerações, essa festa vem entrelaçando cotidiano e história - presente, passado e futuro - ao produzir relações vividas para a tradição. Como narrativa, seus ritos contam uma história que tece o sagrado ao cotidiano, revelando uma realidade que se produz e se reproduz como experiência. A música constitui-se enquanto uma prática viva de interação entre devotos e foliões, em relação, possibilitando um entendimento amplo da construção humana.

Promover as festas significa para os reinadeiros não apenas relembrar o passado, mas é nesse momento que recriam a história sagrada de sua família e de seus mitos de origem. Festejar é o próprio sentido da vida. Cantar e dançar são um dever, um trabalho, uma missão, uma promessa. Foi assim que ensinaram os antepassados. A Festa do Rosário 
permanece até hoje porque é compromisso de amor, uma função sagrada recebida pelos ancestrais. Cada vez que tocam, cantam, dançam, batem caixa, ouvem e repetem histórias, os reinadeiros não estão fazendo sempre a mesma coisa. Nos momentos em que estão conversando, ouvindo histórias, trocando informações, batendo caixas, tocando o patangome ou mesmo participando como visitantes de outras festas do Reinado, estão habilitando-se ${ }^{11}$, apropriando-se do modo de ser reinadeiro. Assim, mais que repetir ou reproduzir, os reinadeiros exercitam e experimentam a festa e podem, assim, aprendê-la. E por meio dessa aprendizagem se constituem reinadeiros. O tornar-se reinadeiro é mais que seguir uma tradição, não é dom, vocação ou aceitação de um destino inevitável, é um fazer/aprender que envolve relações de poder, acordos, negociações e conflitos inerentes à vida social. E é a partir desse envolvimento que apreendem os gestos, os significados, as emoções, as disposições corporais e identidades que o produzem integrante dessa comunidade. É nesse envolvimento festivo, comunitário e identitário que o reinadeiro se constitui, cotidianamente.

No contexto da prática de tocar sinos, além da habilidade técnica e de conhecimento, verificamos um saber que promove aos sineiros uma relação afetiva e devocional com o objeto sino, dando vida aos mais variados tipos de toques. Assim, a prática sineira se faz presente na comunidade são-joanense sendo aprendida de geração em geração, com vistas a valorizar e perpetuar essa expressão da cultura, regada de ancestralidade africana. Processo este permeado pelo entrelaçamento de histórias, nas quais o toque dos sinos abrange um universo de relações envolvendo os sineiros, os sinos, os aprendizes do ofício de sineiro, as festividades religiosas e suas práticas de lazer e a comunidade.

Portanto, as festas, as crenças, os saberes e fazeres, tradições, danças, o modo de vida, os bens, objetos e instrumentos, entre outras incontáveis práticas, ou seja, todo o conhecimento e aparato humano, nos mais variados contextos culturais, compõem o patrimônio das comunidades. Práticas estas vivenciadas, ritualmente, pelas comunidades, celebrando as histórias e memórias de um passado que se faz presente.

11 Adquirindo uma habilidade entendida aqui, como afirma Ingold (2000), na possibilidade de estabelecer relações entre percepção/ação em um contexto dinâmico e ricamente estruturado. 


\section{Referências}

Assis, S. C. Música e dança na Festa de Reis em Carmo do Cajuru - MG: uma etnografia construída no envolvimento e no movimento de pessoas, instrumentos e sonoridades. 183f. Tese (Doutorado) - Escola de Educação Física, Fisioterapia e Terapia Ocupacional, Universidade Federal de Minas Gerais, 2016.

Bakhtin, M. A cultura popular na Idade Média e no Renascimento: o contexto de François Rabelais. São Paulo: Hucıtec; Brasília, DF: Editora da Universidade de Brasília, 1999.

BALlart, J. El patrimonio histórico y arqueológico: valor y uso. Barcelona: Ariel, 1997.

Barth, F. Os grupos étnicos e suas fronteiras. In: Poutignat, P.; Streifffenart, J. (Org.). Teorias da identidade. São Paulo: Editora da UNESP, 1998.

Brasil. Constituição (1988). Artigo 216. Brasília, DF: 5 out. 1988. Disponível em: <http://www.senado.gov.br/atividade/const/con1988/ CON1988_05.10.1988/art_216_.asp >. Acesso em: 1 abr. 2018.

Brasil. Decreto n. 3.551, de 4 de agosto de 2000. Institui o Registro de Bens Culturais de Natureza Imaterial que constituem patrimônio cultural brasileiro, cria o Programa Nacional do Patrimônio Imaterial e dá outras providências. Diário Oficial da União, Brasília, DF, 7 ago. 2000.

CABeza, M. C. Ócio como referente na formação do novo cidadão. In: Peres A.; Lopes, M. (Coord.). Animação sociocultural: novos desafios. Portugal: Associação Portuguesa de Animação e Pedagogia, 2007. p. 77- 98.

Costa, K. T. O. Arturos, filhos do Rosário: nas práticas sociais, uma história que se revela na Festa de Nossa Senhora do Rosário. 2013. 131f. Dissertação (Mestrado em Lazer) - Escola de Educação Física, Fisioterapia e Terapia Ocupacional, Universidade Federal de Minas Gerais, Belo Horizonte, 2013.

Costa, K. T. Vem que hoje é dia de festa: corpo, território e ancestralidade nas festas da Comunidade Quilombola Carrapatos da Tabatinga - Bom Despacho, MG. 2017. 134f. Tese (Doutorado em Lazer) - Universidade Federal de Minas Gerais, Belo Horizonte, 2017.

DiAs, R. Turismo e patrimônio cultural: recursos que acompanham o crescimento das cidades. São Paulo: Saraiva, 2006.

Gomes, N. P. M.; Pereira, E. A. Negras raízes mineiras: os Arturos. 2. ed. Juiz de Fora: Editora da UFJF, 2000.

INGOLD, T. The perception of the environment: essays on livelihood, dwelling and skill. London and New York: Routledge, 2000. 
IngOLD, T. Da transmissão de representações à educação da atenção. Educação em Revista, Porto Alegre, v. 33, n. 1, p. 6-25, 2010.

INGOLD, T. Estar vivo: ensaios sobre movimento, conhecimentos e descrição. Petrópolis: Vozes, 2015.

IPHAN - Instituto do Patrimônio Histórico e Artístico Nacional. Brasília, DF: s./d. Disponível em: <http://portal.iphan.gov.br/>. Acesso em: 1 abr. 2018.

Iphan. O Toque dos Sinos em Minas Gerais. Dossiê descritivo Iphan. Brasília, DF: 2009a. Disponível em: <http://portal.iphan.gov.br/uploads/ckfinder/ arquivos/Dossie\%20toque\%20dos\%20sinos(1).pdf>. Acesso em: 1 abr. 2018. Iphan. Parecer Iphan. Processo n. 01450.011821/2009-82. Brasília, DF: 2009b. Disponível em: <http://www.ihgsaojoaodelrei.org.br/repositorio/ File/parecer_toque_sino.pdf $>$. Acesso em: 1 abr. 2018.

Iphan. Parecer Iphan. Processo n. 27/GR/DPI. Brasília, DF: 2009c. Disponível em: <http://portal.iphan.gov.br/uploads/ckfinder/arquivos/ Parecer\%20Toque\%20dos\%20Sinos.pdf>. Acesso em: 1 abr. 2018.

Iphan. Proposta para a composição do dicionário. Brasília, DF: s./d. Disponível em: <http://portal.iphan.gov.br/pagina/detalhes/1028>. Acesso em: 1 abr. 2018.

Laraia, R. B. Patrimônio imaterial: conceitos e implicações. In: Teixeira, J. G. L. C.; Garcia, M. V. C.; Gusmão, R. Patrimônio imaterial, performance cultural e (re)tradicionalização. Brasília, DF: ICS, UnB, 2004.

Lave, J. Apprenticeship in critical ethnographic practice. Chicago: University of Chicago Press, 2011.

Lave, J. Aprendizagem como/na prática. Horizontes Antropológicos, Porto Alegre, ano 21, n. 44, p. 37-47, 2015.

Machado, C. G.; Dias, R. Patrimônio cultural e turismo: educação, transformação e desenvolvimento local. Patrimônio: Lazer \& Turismo, Santos, v. 6, n. 8, p. 1-11, out./dez. 2009. Disponível em: <https://www.researchgate. net/file.PostFileLoader.html?id=5745f84bdc332def7d14e58e\&assetKey=AS \%3A365709466062848\%401464203339240>. Acesso em: 30 mar. 2018.

Maroun, K. Jongo e educação: a construção de uma identidade quilombola a partir de saberes étnico-culturais do corpo. 2013. 201f. Tese (Doutorado em Educação) - Rio de Janeiro, Pontifícia Universidade Católica do Rio de Janeiro, 2013.

Martins, L. M. Afrografias da memória: o reinado do Rosário no Jatobá. Belo Horizonte: Mazza Edições, 1997. (Coleção Perspectiva). 
Maturana, H. et al. A ontologia da realidade. Belo Horizonte: Editora UFMG, 2014.

Morin, E. Ciência com consciência. 15. ed. Rio de Janeiro: Bertrand Brasil, 2013.

MTUR - Ministério do Turismo. Turismo cultural. Brasília: DF. Disponível em: $<$ http://www.turismo.gov.br/sites/default/turismo/o_ministerio/publicacoes/ downloads_publicacoes/Turismo_Cultural_Versxo_Final_IMPRESSXO_.pdf $>$. Acesso em: 1 abr. 2018.

Munanga, K. A identidade negra no contexto da globalização. Revista Ethnos Brasil, São Paulo: UnesP, n. 1, p. 11-20, mar. 2002.

Pereira, J. K. C. Entre festejos e ofícios: um olhar acerca das manifestações culturais do Toque dos Sinos de São João del-Rei/Minas Gerais. 2017. $168 f$. Dissertação (Mestrado em Lazer) - Universidade Federal de Minas Gerais, Belo Horizonte, 2017.

Ribeiro Júnior, J. C. N. A festa do povo: pedagogia de resistência. Petrópolis: Vozes, 1982.

Rodrigues, M. Preservar e consumir: o patrimônio histórico e o turismo. In: Funari, P. P.; Pinsky, J. (Org.). Turismo e patrimônio cultural. São Paulo: Contexto, 2003. p. 15-24.

Sodré, M. Claros e escuros: identidade, povo e mídia no Brasil. Petrópolis: Vozes, 1999.

UnEsco - Organização das Nações Unidas para a Educação, a Ciência e a Cultura. Convenção para salvaguarda do patrimônio cultural imaterial. Paris, 17 out. 2003. Disponível em: <http://unesdoc.unesco.org/ images/0013/001325/132540por.pdf >. Acesso em: 30 mar. 2018.

Zerbo, J. K. (Org.). História geral da África. São Paulo: Ática; UnesCo, 1982. 


\section{CAPÍTULO 12}

\section{LAZER, PRÁTICAS ALIMENTARES E MEDIAC̣ÃO CULTURAL: DISCUTINDO O GASTRONÔMICO}

Susana Gastal

Ana Maria Costa Beber

Este capítulo apresenta as práticas alimentares como importantes mediadoras das relações humanas, destacando sua presença contemporânea nos cenários urbano e rural, nos quais a comensalidade se mantém associada à hospitalidade, mas inova em sua aproximação com o lazer e o entretenimento. Nas palavras de Hannigan (1999), o eatertainment ${ }^{1}$ companha um sistema urbano em que parte da população residente superou a escassez alimentar e agora pode se dar o luxo de brincar com a comida. Por sua vez, em menor grau, mas no mesmo sentido, a comida desempenha novos papéis nas neorruralidades.

É importante contextualizar que a função realizada pelos ritmos das estações da natureza no favorecimento da variação alimentar humana foi assumida pela tecnologia. $\mathrm{Na}$ forma de processos bioquímicos, genéticos e de transporte dos alimentos, a tecnologia permite sua disponibilização variada e em quantidade durante todo o ano. Tal presença global de alimentos, antes restritos à sazonalidade e locais de produção natural, como decorrência trouxe à cena novas questões, tais como a insegurança alimentar e a alteração de sabor, mesmo de pratos tradicionais. Ainda, se há maior quantidade, a qualidade biológica dos alimentos tem sido questionada em virtude de alterações ocasionadas, por exemplo, pela adubação química e a utilização de agrotóxicos na lavoura, além do uso de

1 Palavra de difícil tradução, mas que seria algo como comida entretenimento. 
fungicidas no processo de armazenamento, que acabam por afetar tanto o rural como o urbano.

O contexto descrito permite inferir que não será apenas a relação com a comida e o comer que se apresentará em novo formato, mas que estes afetarão profundamente a cultura, o lazer e os cotidianos, permitindo pensar as práticas alimentares como categoria para a apreensão de processos contemporâneos de mudanças. Como proposto por Millán (2002), as crenças, normas, valores e formas de interação social que dão significado à ação social estão representados nas práticas alimentares de cada grupo social. A cultura concretiza-se no prato, e as condutas humanas ligadas à alimentação são resultado de interações e aprendizados múltiplos. Compreende-se a alimentação, assim, como um texto que significa os processos socioculturais de um grupo, que define as pessoas e as relações que elas mantêm entre si, em suas práticas sociais.

Olhando a comida como expressão cultural, os fazeres cotidianos nas cozinhas são formas de unir matéria e memória, vida e ternura, presente e passado, invenção e necessidade, imaginação e tradição, tudo imerso em gostos, cheiros, cores, sabores e gestos, instrumentos e ingredientes, como bem colocado por Certeau (2011). Outro momento igualmente complexo em suas múltiplas práticas e significações é o da comensalidade à mesa, como se verá adiante.

Como afirma a banda Titãs, filosofando em português, "a gente não

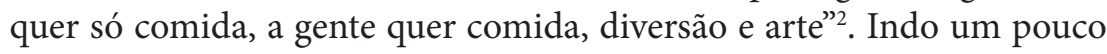
além, o cenário contemporâneo desenha-se como o momento em que as sociedades urbanizadas, em especial aquelas presentes nas grandes cidades e que repercutem nas neorruralidades, não mais diferenciam diversão, arte e comida, pois todas passam a se dar, de maneira mais enfática que em outros tempos, como sinônimo de festa, extrapolando as relações da tradição, que as via como campos independentes. Como exemplo disso, Mkono (2013), ao estudar o convívio entre culturas locais, de turistas da própria África que visitam o Zimbabwe, constatou que estes consideram como significativo para avaliar as performances culturais locais menos a autenticidade e mais o fator estético e o talento artístico, o que se pode inferir que a glamourização é um valor que se sobressai nessas relações.

2 “Comida”, composição de Arnaldo Antunes, Marcelo Fromer e Sérgio Britto lançada no álbum Jesus não tem dentes no país dos banguelas, gravado pela WEA, 1987. 
Nas páginas seguintes, vamos olhar com mais vagar essas questões, iniciando por contextualizar a pós-modernidade e suas marcas na cultura, seguindo com uma discussão sobre a abrangente presença da urbanização e, conforme estudos anteriores, da cidade, cada vez mais organizada em espaço de praça e palco, alcançando a comida e o comer como importante expressão cultural nesse contexto, sem desconsiderar a presença histórica da comensalidade, para demonstrar certa inversão contemporânea, indo da prioridade da comensalidade sobre a festa para o vanguardismo da festa sobre a comensalidade.

\section{Pós-modernidade}

A Segunda Grande Guerra Europeia encerrou-se em 1945, deixando os países envolvidos no conflito - em especial os da Europa - com o desafio de reconstruírem sua economia, suas cidades e sociedades. A economia expandiu-se fortemente nas décadas seguintes, com o aporte financeiro impulsionando a informatização dos sistemas econômico e produtivo. Nesse processo, ganhou relevância também a importação/ exportação de produtos mediante a presença de contêineres, ocasionando a redução dos custos de transportes de mercadorias e insumos, com desdobramentos importantes nas áreas associadas aos alimentos, permitindo, por exemplo, que uma cerveja alemã ou americana chegue a supermercados brasileiros a preços competitivos.

A mesma informatização estendeu-se aos meios de comunicação dando velocidade e maior alcance à informação nos veículos tradicionais (televisão, rádio, jornais...), além de novas possibilidades com a introdução da internet. E entre os conteúdos que passam a ser ofertados em todos os meios de comunicação estão aqueles associados à comida. Abundam programas destacando receitas culinárias e seu preparo, quer nos horários “femininos” das manhãs, quer na profusão de vídeos disponibilizados no YouTube. Referências a tais conteúdos aparecem mesmo em estudos sobre práticas alimentares nas áreas rurais, onde as pessoas destacam a importância dos programas de televisão, nas alterações do preparo de pratos e na organização de seus cardápios familiares (CosTA Beber; Menasche, 2011; Costa Beber; Gastal, 2017).

O pós-guerra também significou a alteração de comportamentos sociais. A mulher conquista um novo papel, que se profissionalizou e passou a integrar o mercado de trabalho. A pílula anticoncepcional permitindo 
a escolha de uma gravidez consciente e desejada, ocasionando a constituição de famílias menores, e, na passagem do século Xx para o XXI, a forte presença do single, ou seja, de pessoas solteiras (ou não) vivendo sozinhas. O novo modelo familiar - quer como causa, quer como consequência - logo será atendido por inovações nos desenhos das cozinhas, com maior automação em aparelhos e equipamentos de toda ordem, que facilitam e agilizam as tarefas de preparo de alimentos, ou mesmo com a introdução de insumos ou de pratos prontos, industrializados.

Outra alteração perceptível, em especial nas três décadas finais do século $\mathrm{xx}$, foi a consolidação de um novo tratamento e visibilidade conquistados pelas minorias. Movimentos como o Woman's Lib (Liberação das Mulheres), Black Power (Poder Negro) e Gay Power (Poder Gay), nascidos nos Estados Unidos, espalharam-se pelo mundo promovendo visibilidade e espaços de autoexpressão para minorias étnicas e de gênero. Associadas às novas identidades étnicas (ou identificações, como prefere Stuart Hall) emergem as cozinhas significativas para esses grupos socialmente minoritários, com incorporação de pratos, temperos e formas de preparo em restaurantes especializados e, em alguns momentos, para além deles. No Brasil, o exemplo mais apropriado talvez seja a popularização da culinária japonesa (ou de suas releituras locais), fazendo do sushi (ou de suas releituras) presença também em churrascarias e restaurantes populares.

Se a sociedade muda, alteram-se suas expressões culturais. A noção de patrimônio - ou seja, de expressões culturais vistas como diferenciadas e próprias a um grupo - amplia-se no que diz respeito a questões conceituais e temporais. Temporais, porque prédios e objetos não mais precisam ser muito velhos para ganharem reconhecimento. É o caso dos novos museus, os quais, mesmo que recém-inaugurados, são reconhecidos como patrimônio. A ampliação conceitual acontece, por sua vez, porque, a exemplo dos bens materiais, os bens imateriais, como cantos, rituais, falares, modos de vida e festas, são reconhecidos como culturais, situação que inclui a gastronomia.

E por que a gastronomia é um bem imaterial? Porque ela supõe não só a materialidade dos ingredientes, mas, de modo muito especial, de técnicas de preparo ou modos de fazer, tanto em sua versão erudita de alta gastronomia, como nas versões populares das comidas de rua ou dos restaurantes mais modestos. No caso do Acarajé da Bahia, a certificação de patrimônio imaterial pelo Instituto Brasileiro do Patrimônio 
Histórico e Artístico Nacional (IPHAN) contemplou não o prato, mas o ofício das baianas de Acarajé3.

Assim, tem-se a valorização do fenômeno culinário e dos produtos de caráter local, associados aos modos de vida, aos produtos da terra e seu terroir, aos saberes e às técnicas de preparo, ao prazer à mesa e ao desfrute dos sabores, à tradição e à identidade - tão bem tratados pelo movimento slow food -, que se colocam como mediadores culturais dos territórios. Nessa perspectiva, Costa Beber e Gastal (2017) relatam que o turismo rural e a sua interface com a culinária, enquanto referente a identidades e constituinte de patrimônio familiar, foram capazes de transformar o significado da alimentação praticada em espaços rurais que recebem visitantes urbanos. Nesse processo identitário, elementos interessantes são evidenciados e refletem-se na classificação de comida turística, comida da cidade e comida nossa, no âmbito das ruralidades pesquisadas pelas autoras.

Não menos importante, agora, é acrescentar que todo o aqui apresentado em relação ao novo momento cultural, provisoriamente tratado como pós-moderno, apresenta como marcas importantes a alta mobilidade de pessoas, mercadorias, capitais, objetos e ideias, e a expansão territorial da cidade e do urbano enquanto mentalidade a se impor sobre o rural.

\section{Cosmopolitismo}

O que se costuma denominar de cidade demanda a presença: da concentração de tempo, expressa na forma de monumento; da praça, ou seja, de lugares formatados para o estar-juntos; e de palco, como espaços nos quais seja possível ver e ser visto. A presença dos dois primeiros, em especial, remonta aos primórdios da cidade, cerca de 3.000 a.C., na Mesopotâmia, e se consagra nas culturas clássicas grega e romana. A matriz palco seria mais recente, reportando ao teatro, que na Idade Média ocupava as escadarias fronteiras à igreja e a outros fóruns como espaços de atuação. Mas aos poucos a cidade foi transformando a si mesma em um grande palco, no qual todo urbanita buscava o exercício do olhar, no ver e no ser visto. A visibilidade apresenta-se como valor significante, em

3 Outras informações disponíveis em: <http://portal.iphan.gov.br/pagina/detalhes/58>. Acesso em: 20 maio 2018. 
especial a partir das grandes reformas de Paris no século XIX. Naquele momento, a urbanização da Cidade Luz introduziu grandes parques e praças, assim como largos canteiros nas avenidas, como forma de incentivo às caminhadas descompromissadas, ao deambular. Como pressuposto, a "exaltação ao espaço público como significantes do encontro, da troca (de mercadorias, de bens simbólicos, de crenças, saberes e história) e da celebração" (GASTAL, 2014, p. 44).

Os imaginários associados à Praça e ao Palco, assim construídos ao longo do tempo na sociedade ocidental, alimentarão o sonho e o ideal Urbano que a Cidade buscará materializar nos séculos subsequentes, quer no centro do núcleo interiorano, quer nas ruas comerciais das grandes metrópoles. Um texto que no imaginário pós-moderno, ao procurar reconstituir espaços de festa e de encontro, de trocas de bens materiais e de bens simbólicos com liberalidade de acesso e informalidade de uso - ou seja, a Praça -, permanecerá ativo. $\mathrm{Na}$ alma dos shoppings centers metropolitanos, nos halls de entrada de hotéis e edifícios corporativos, nos bares da Cidade ou na roda do cafezinho em escolas e escritórios, lá estarão Praça e Palco [Gastal, 2014, p. 44].

A cidade contemporânea então se atualizou como praça e palco tendo como base dois contextos: primeiro, o resgate generalizado dos centros históricos de cidades americanas e europeias na segunda metade do século $\mathrm{xx}$, prática que logo se estendeu aos demais continentes, reproduzindo-se nestes a estética já estabelecida nos primeiros. Outro momento aconteceu com a extrapolação das lógicas dos parques Disney, pautados em espaços que se caracterizassem como praça e palco, associando, para tal, imaginação e tecnologia a um visual de grande beleza cênica como espaço privilegiado, em que o comprar e o comer passam a estar associados como parte do divertimento.

Hannigan (1999) utiliza os termos shopertaiment e eatertaiment (assim como edutaiment, todos presentes nos parques temáticos Disney) como marcas do que denomina de fantasy city, que seria exaltada por um imaginário urbano no qual a cidade é vista como o local da festa, do saber, da cultura e da representação. Todos estes, nesse novo momento, tratados como produtos a serem comercializados nas cidades ditas globalizadas ou pós-modernas, em uma economia urbana movimentada pelo turismo, esportes, cultura e entretenimento, embalados ou não na 
forma de grandes eventos. Para Hannigan (1999), esse desenho e desempenho imitariam o que os parques temáticos, no pós-1980, consagraram.

O autor ainda destaca que a cidade como espaço de consumo não seria uma realidade nova, mas que a renovação estaria na maneira como esse consumo se realiza, associado à festa e, ato contínuo, como lazer. Procura-se construir sinergias como extensões de marcas, tomando como base um produto original, sob a lógica de que atividades como o ir às compras, o comer e o desenvolver práticas educativas tenham como componente extra o virem embrulhadas como entretenimento, ou seja, associadas ao divertimento, ao lazer e ao otimismo. Note-se que tal tratamento reduz o lazer ao mero divertimento, distanciando-se do proposto por teóricos da área.

A hegemonia física da cidade leva à expansão desse estilo urbano, como um cosmopolitismo. A palavra cosmopolita teria origem no grego kosmopolites (kosmós/mundo; polites/cidadão), ou seja, refere-se a alguém que se coloca no mundo sem maiores laços com seu lugar de origem, adaptando-se facilmente a novos locais e situações. A cidade cosmopolita é aquela que recebe gente vinda de muitos lugares, "e onde é possível notar a influência de diversas culturas na alimentação, arqui-

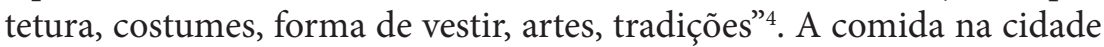
cosmopolita estaria marcada pela oferta de pratos étnicos, mas muito especialmente por releituras dessa gastronomia, para dar espaço ao

desejo de que a alimentação favoreça a evasão, proporcionando refeições diferentes, numa tentativa de rompimento com a monotonia, que pode ser exemplificada pelo desenvolvimento - principalmente nos meios urbanos - da alimentação étnica, que reproduz costumes alimentares de diferentes povos. Nessa mesma vertente desponta a aspiração pelo refinamento, que revela a busca da variedade e da sofisticação alimentar, demonstrada pelo aumento de oferta, tanto em quantidade como em diferenciação, de itens alimentares no mercado [ProençA, 2010, s./p.].

Franklin (2007) contribui para o debate com uma análise muito pertinente. Segundo o autor, com a consolidação do turismo como mentalidade característica do momento contemporâneo que permeia a

4 Disponível em: <https://www.significados.com.br/cosmopolita/>. Acesso em: 20 maio 2018. 
sociedade, os comportamentos turísticos invadiram os cotidianos não sendo mais necessário estar em viagem para frequentar museus ou restaurantes sofisticados para desfrute de experiências gastronômicas diferenciadas, por exemplo. As duas ações fazem parte dos neocotidianos e são exercidas com desempenho semelhante àquele praticado em viagem. Em outros termos, a mentalidade turística invade e marca a vida cotidiana para além do momento de viagem.

\section{Neorruralidades}

Em âmbitos rurais, emerge o que os teóricos têm tratado como neorruralidades, definidas como o acréscimo de funções ao campo, que deixa de ser somente espaço de produção agrícola ou de pecuária e passa a desenvolver atividades como a proteção da biodiversidade e dos patrimônios natural e cultural; de incentivo ao lazer e turismo; de moradias de segunda residência; entre outras. Essas atividades e funções atuam promovendo novos contatos e outras formas de interação entre os sujeitos rurais e urbanos. Nesse sentido, ao pensarmos nas relações de hospitalidade que envolvem o turismo e o lazer, é possível perceber que as comidas (étnicas, identitárias, tradicionais, especializadas) passaram a ser entendidas como produto de consumo por sujeitos urbanos e como símbolo identitário construído sobre um imaginário de ruralidade.

No cenário neorrural, as práticas alimentares mantêm-se como constituintes do patrimônio familiar, revalorizado na presença do turismo. A interação entre visitantes e visitados promove mudanças socioculturais, nas quais se hibridizam as práticas culinárias herdadas da população receptora, com os gostos e as demandas de consumo dos visitantes. São alterações que têm permitido a manutenção da família no campo, mas que provocam mudanças em seus modos de vida e em suas práticas alimentares, em um processo dialético decorrente não só da presença do turista, mas também resultante das mudanças nos modos de produção agrícola, pela modernização e industrialização do campo, além da mentalidade urbana que chega a esse ambiente (Costa Beber; Menasche, 2011).

Outra pesquisa que atesta a relevância da alimentação como forma de compreender processos culturais contemporâneos e as neoexpressões dos cotidianos e do lazer observou as práticas alimentares domésticas e turísticas em Antônio Prado, Rio Grande do Sul, cidade que integra o cenário de neorruralidades, por suas proximidade e inserção rural. Ali, 
a comida é entendida como expressão da cultura ítalo-brasileira e, nessa condição, transposta como atrativo turístico, associado a um imaginário de comida cotidiana e de italianidade. O cardápio estruturado pela comunidade incorpora hibridismos culturais que formulam uma gastronomia possível na mescla entre raízes culturais imigrantes e a oferta de insumos possíveis no ecossistema local, alimentando a etnicidade itálica como marcante na construção da identidade local. Na transposição do familiar para o turístico no âmbito de festas locais, como a Noite Italiana, percebe-se que a comida ítalo-brasileira - apresentada como italiana torna-se símbolo do lugar e da cultura do destino, incentivando a produção agrícola local e sua competitividade na relação local-global (CosTA Beber; Gastal 2017).

\section{Comensalidade}

Se o cosmopolitismo leva a sociedade a conviver com maior diversidade, seja como parte do local ou em hibridizações mais recentes com outras matrizes culturais, a comida e o comer colocam-se na mesma perspectiva. $\mathrm{O}$ que comer, tradicionalmente, antes se associava apenas a questões de gosto, que apresenta três momentos de estruturação:

O primeiro, que se situa dentro de uma ordem religiosa dos alimentos, na qual as sensações gustativas de cada sujeito devem se conformar aos moldes estruturados, como também estas sensações eram raramente exprimidas. O segundo episódio se vincula ao caráter subversivo dos prazeres, que já anunciavam a modernidade e reduziam o peso das instituições sobre os indivíduos, uma dinâmica que se amplifica no final da Idade Média. O conceito de "bom gosto" emerge se tornando um instrumento de classificação das distinções sociais. O terceiro e último episódio se refere ao momento atual com a multiplicação dos universos de escolhas nas quais as alternativas de ações se diversificam e a regulação do gosto se impõe como um regulador [Kaufmann, 2005 apud SANTOS, 2008, p. 207].

$\mathrm{Na}$ atualidade, indo além do gosto, Santos (2008) descreve uma situação bem mais complexa de hábitos alimentares:

A instituição de novas disciplinas corporais e alimentares implica necessariamente na instituição de uma nova culinária, como 
também de uma nova gastronomia. Por consequência, novos saberes e práticas no trabalho culinário, novos códigos, regras, normas e taxionomias são produzidos. No contexto contemporâneo, emergem noções como a da cozinha light, que funciona dentro de um novo sistema de codificação utilizando novos critérios para selecionar os gêneros alimentícios com baixa caloria e teor de gorduras, portanto menos calórico. A cozinha light se traduz em uma apropriação de novos saberes e práticas em termos de preparação que reduzam a gordura dos alimentos, os tornem nutritivos, e ainda uma nova postura ao comer frente às culinárias tradicionais. Prossegue afirmando os valores da natureza, da leveza e do prazer em comer, a alegria dos coloridos dos pratos. Na visão de Fischler (2001), há uma feminilização do comer, todavia poderíamos supor o estabelecimento de novas relações entre os gêneros, uma vez que os próprios valores femininos e masculinos têm sido constantemente reconstruídos, especialmente no decorrer do século $\mathrm{xx}$ [SANTOS, 2008, p. 240].

Caminho igualmente complexo é traçado pela comensalidade. $\mathrm{O}$ comer junto se faz presente desde os primórdios da civilização no planeta, com diferentes rituais expressando a cultura do grupo e suas formas de socialização. O alimento compartilhado representa vivências comuns que se podem dar nas refeições em família, cotidianas ou em datas comemorativas, em reuniões sociais ou de negócios. Assim, mesmo que a cultura contemporânea seja marcada por profundas alterações dos cotidianos associados ao preparo e consumo de alimentos, os momentos de socialização em torno da comida continuam presentes e, talvez, mais valorizados.

De Boer e Rejowski (2014, p. 19) consideram que comensalidade (do latim mensa) significa conviver à mesa, compartilhando o que, como e com quem se come, em que mangeur (comedor) se distinguiria de comensal: "o comedor é movido por motivos que lhe escapam como um ser biológico, um ser passional e um ser cultural; se refere, no contexto da sociologia da alimentação, ao ser que come, ao contrário do comensal, que significa o ser que come com outro ou com outros".

A contemporaneidade destaca como espaço por excelência do comensal os bares e restaurantes. Gândara et al. (2009, p. 185) registram que, para seus frequentadores, esses locais "acabam se tornando espaços de lazer que passam a integrar a própria vida cultural das localidades". 
Dando prosseguimento, afirmam que tais estabelecimentos têm a capacidade de propiciar o contato e o encontro entre pessoas de forma espontânea, oportunizando vivências e sociabilidades diversas, cristalizando laços criados em outros espaços e que, por conta dos diferentes ritmos de vida dos envolvidos, muitas vezes não são vivenciados nos cotidianos.

[Os restaurantes] são frequentados por pessoas que buscam a comodidade de refeições fora de casa, mas também por aquelas que desejam relaxar, fugir do estresse, divertir-se, reencontrar os amigos, dançar, flertar ou ainda verem e serem vistas. Para esses estabelecimentos, convergem tanto residentes quanto turistas, movidos pelas mais diferentes motivações. E são justamente estas diferentes motivações que terminam por caracterizar tais estabelecimentos enquanto espaços de lazer, espaços sociais, onde se entabulam relações específicas entre seres, grupos, meios e classes, permitindo a prática de atividades livremente escolhidas em um ambiente que propicia o contato entre pessoas [GÂNDARA et al., 2009, p. 186].

Em outros termos simbólicos, Fernandes (1997, p. 14) busca construir uma morfologia destacando que a comensalidade, mesmo como praticada na atualidade, apresentaria algumas marcas recorrentes: aparece frequentemente como expressão de poder e diferencial de classe; a mesa é local de permutas sociais, tanto de companheirismo como de traições; haveria uma relação entre mesa, corpo e beleza, mesmo se considerando que as "concepções da estética são uma função geral da mentalidade de cada época"; as religiões históricas transpõem o cerimonial da mesa para a ritualização sagrada; a comensalidade atual revelaria a quebra da sociabilidade e deixaria a esfera íntima para a esfera social.

Outros fatores sociais contribuem para o desenho das relações contemporâneas com a comida, transcendendo aos espaços de consumo. Fischler (1995) relata que nos países industrializados a alimentação passou a estar disponível em grande quantidade, todavia as novas técnicas de produção agiram no intuito de homogeneização e de padronização, como anteriormente aqui relatado. Contreras (2005) lembra que a modernidade alimentar acarretou a superespecialização, a busca constante do aumento de lucros nas produções agrárias e o êxodo de trabalhadores das zonas rurais, esgarçando os controles sociais tradicionais sobre a produção. As pessoas perdem o contato com o ciclo de vida da produção dos alimentos, sua origem, procedimentos técnicos envolvidos na 
sua conservação, armazenamento e transporte. A preparação culinária ou a pré-culinária deslocaram-se cada vez mais da cozinha doméstica para a fábrica, em que o processamento, do ingrediente ao prato, é inteiro mecanizado.

A globalização da economia e a industrialização exercem um papel importante, devido à gama de produtos e serviços distribuídos em escala mundial e ao suporte publicitário envolvido. Uma tendência crescente para o consumo de alimentos de maior concentração energética é promovida pela indústria de alimentos através da produção abundante de alimentos saborosos, de alta densidade energética e de custo relativamente baixo. A globalização atinge a indústria de alimentos, o setor agropecuário, a distribuição de alimentos em redes de mercados de grande superfície e em cadeias de lanchonetes e restaurantes. A difusão da ciência nos meios de comunicação e o uso do discurso científico na publicidade de alimentos também exercem seu papel no cenário das mudanças alimentares. Embora nos países mais pobres estas tendências de consumo estejam distribuídas diferentemente nos segmentos de classes sociais de acordo com as possibilidades de acesso aos bens de consumo, no plano simbólico os desejos de consumo por si só marcam uma inclinação a este perfil alimentar [Diez GARCiA, 1997, s./p.].

Proença (2010) segue na mesma linha de argumentação, reforçando o atual distanciamento humano em relação aos alimentos, da sua produção ao seu preparo, tanto espacial como temporal. Espacial, pela distância física das cidades em relação às áreas do agronegócio. Temporal, porque desaparece a sazonalidade do consumo: todas as frutas e todas as hortaliças estão disponíveis doze meses por ano nos grandes mercados.

Destaca-se também a importância crescente da alimentação fora de casa, com os restaurantes suplantando a sua origem etimológica de "restauradores de forças" para assumirem outros papéis na dinâmica econômica e social. Assim, no plano de alimentação coletiva, nota-se a expansão de prestadores de serviços de alimentação em empresas, hospitais e escolas, entre outros. E na alimentação comercial se observam desde pequenos estabelecimentos até conglomerados de fast-food, fenômeno originado nos Estados Unidos e difundido mundialmente. Além da possibilidade de massificação de cardápios e indução de novos comportamentos alimentares, 
muitas vezes, essas empresas de alimentação coletiva e comercial difundem também formas diferentes de trabalhar com os alimentos, contribuindo para o discutido distanciamento [ProençA, 2010, s./p.].

O cenário repete-se tanto no consumo externo a casa quanto nas refeições domésticas, em que congelados e alimentos pré-prontos reduzem ao mínimo a intervenção em seu preparo. Em direção oposta, há a gourmetização do preparo e do consumo, amparados em uma ampla cadeia produtiva que vai da produção de especiarias, passando por butiques de alimentos, pela mediação de livros, revistas, sites, blogs, documentários e outros programas televisivos, com destaque para figura do chef. "Tais profissionais, com a tendência globalizante, trabalham para além do fazer comida, divulgando comportamentos e vendendo produtos associados, muitas vezes induzindo práticas alimentares" (ProençA, 2010, s./p.). O autor destaca que os espaços gourmets, muitas vezes, não parecem destinados a cozinhar, mas colocam-se como diferencial de decoração. Em outras palavras, o preparo de comida nesses espaços seria um detalhe de menor importância, o que não se aplica ao consumo. Somam-se a essas outras modificações:

Não obstante, esta suposta liberdade aporta com ela um conjunto de incertezas. Tais condutas têm relação com a tese sobre a "gastro-anomia" sustentada por Fischler (2001), que aponta para uma desestruturação das práticas do comer. Estas podem ser caracterizadas pela desregulação das refeições - assim como a sua simplificação, uma redução do tempo dedicado a elas e a crescente importância da alimentação fora dos horários tradicionais. Crescem também as refeições no trabalho, não apenas nos refeitórios, mas também dentro do próprio local de trabalho, nas salas de reuniões com refeições rápidas, fast-food, dentre outros [...]. Assim, o comer socializado, que era uma prática cotidiana e repetitiva, fica reservado para o espaço de lazer [SANTos, 2008, p. 38].

Proença (2010) salienta, ainda, que entre as grandes tendências de comportamento em relação à alimentação nas sociedades do consumo, especialmente em países industrializados, estão a autonomia, a conveniência, a desestruturação das refeições, o convívio, o cosmopolitismo, o refinamento, a valorização do natural, a valorização da alimentação fora de casa, incluindo as questões de saúde e de equilíbrio alimentar. É nesse 
cenário contemporâneo que a alimentação aparece como mediadora das relações sociais enquanto constituinte de identidades, valores, memórias, heranças, atualizações e reelaborações. Sua associação à hospitalidade, ao lazer, ao entretenimento e ao turismo evidencia as tramas sociais e os modos de vida das sociedades, sejam elas em contexto de neorruralidades ou cosmopolitismo.

\section{Para finalizar}

A humanidade passou de uma fase de escassez alimentar para sua oferta abundante, o que não significa dizer que a fome não seja presença diária para boa parte da humanidade. No entanto, se abunda o alimento, cresce a escassez de tempo para preparar o próprio alimento, para estar com amigos, para o lazer qualificado. A tendência então é que as práticas culturais passem a associar componentes múltiplos: a hora de comer associa-se ao tempo para estar com amigos e familiares e como oportunidade de usufruto de algum lazer. Nessa condição, o comer deverá se dar como alegria e divertimento. E não podemos esquecer: a criança, quando pequena, brinca, diverte-se e aprende enquanto come.

As práticas alimentares, para além das questões da fome, nos permitem compreender as dinâmicas da sociedade e as formas de organização social. Como texto, falam sobre os modos de vida, sobre as redes agroalimentares, sobre o padrão de consumo, tanto em sociedades rurais como urbana. Aliás, aqui também se compreende esse movimento de interação em que o lazer é um fenômeno importante nas formas de sociabilidade e hospitalidade.

Ao colocar a comida como produto de lazer na sociedade urbanizada, tem-se uma nova dimensão que permite pensar também nos significados mais essenciais da vida humana, da partilha e do compartilhamento do alimento em rituais de acolhimento, que buscam criar sensações de satisfação em torno da própria vida, indo além das questões nutritivas que envolvem o ato de alimentar-se. Essas questões estão associadas e presentes nos novos padrões familiares, seja nas famílias tradicionais ou nas contemporâneas, ou no single. Quer dizer, a alimentação passa a instaurar modelos de vivências em grupos ou individuais, seja pelas comidas de rua, pelos food trucks, pelas comidas gourmets, pelas comidas tradicionais, uma dinâmica importante que permite externalizar valores humanos da contemporaneidade. 


\section{Referências}

Certeau, M.; Giard, L.; Mayol, P. A invenção do cotidiano: morar, cozinhar. Petrópolis: Vozes, 2011. v. 2.

Contreras, J. Patrimônio e globalização: o caso das culturas alimentares. In: Canesqui, A. M.; Gracia, R. W. D. (Org.). Antropologia e nutrição: um diálogo possível. Rio de Janeiro: Fiocruz, 2005, p. 129-145.

Costa Beber, A. M. C.; Gastal, S. Turismo gastronômico, cultura e comida de festa. Dos Algarves: A Multidisciplinary e-Journal, Algarve, v. 30, p. 58-71, 2017.

Costa Beber, A. M.; Menasche, R. Turismo rural e alimentação, identidade e patrimônio: um olhar sobre os Campos de Cima da Serra em tempos de nostalgia. Revista de Economia Agrícola, São Paulo, v. 58, n. 1, p. 87-99, 2012.

De Boer, L.; Rejowski, M. Turismo gastronômico e hospitalidade em Curitiba: um estudo sobre um restaurante de Santa Felicidade. Revista Turismo \& Desenvolvimento, Campinas, v. 1, n. 21/22, p. 141-150, 2014.

Diez Garcia, R. W. Práticas e comportamento alimentar no meio urbano: um estudo no centro da cidade de São Paulo. Cadernos de Saúde Pública, Fiocruz, v. 13, n. 3, p. 455-467, 1997.

Fernandes, A. F. Ritualização da comensalidade. Repositório, Universidade do Porto, p. 7-30, 1997. Disponível em: <https://repositorio-aberto.up.pt/ bitstream/10216/9045/2/1412.pdf>. Acesso em: 20 set. 2016.

Fischler, C. El (h)omnívoro: el gusto, la cocina y el cuerpo. Barcelona: Anagrama, 1995.

Franklin, A. The problem with tourism teory. In: Ateljevic, I.; Pritchard, A.; Morgan, N. The critical turn in tourism studies. Oxford: Elsevier, 2007. p. 131-148.

Gândara, J. M. G.; Gimenes, M. H. S. G.; Mascarenhas, R. G. Reflexões sobre o turismo gastronômico na perspectiva da sociedade dos sonhos. In: Netto, A. P.; Ansarah, M. G. R. Segmentação do mercado turístico: estudos, produtos e perspectivas. Barueri: Manole, 2009. p. 179-191.

GASTAL, S. Lazer e a animação turística em cidades médias: a contribuição dos imaginários praça e palco. Revista Brasileira de Estudos do Lazer, Belo Horizonte, v. 1, n. 2, p. 39-53, 2014.

Hall, S. A identidade cultural na pós-modernidade. Rio de Janeiro: DP\&A, 2006.

HANNIGAN, J. Fantasy city: pleasure and profit in the postmodern metropolis. Londres: Routledge, 1999. 
Millán, A. Malo para comer, bueno para pensar: crisis en la cadena socioalimentaria. In: Gracia, M. A. (Coord.). Somos lo que comemos: estudios de alimentación y cultura em España. Barcelona: Ariel, 2002. p. 15-38.

Mкоno, M. African and Western tourists: object authenticity quest? Annals of Tourism Research, Elsevier, v. 41, p. 195-214, 2013.

ProençA, R. P. C. Alimentação e globalização: algumas reflexões. Ciência e Cultura, Campinas, v. 62, n. 4, p. 43-47, 2010.

SAntos, L. A. S. O corpo, o comer e a comida: um estudo sobre as práticas corporais e alimentares no mundo contemporâneo. Salvador: EdufBA, 2008. [on-line]. Disponível em: <http://books.scielo.org/id/38m/pdf/ santos-9788523211707.pdf>. Acesso em: 2 fev. 2019. 


\section{TURISMO SOCIAL E MEDIAC̣̃̃ES: \\ PROBLEMATIZANDO UM PROJETO DE EXTENSÃO DA UNIVERSIDADE FEDERAL FLUMINENSE}

Bernardo Lazary Cheibub

\section{Turismo enquanto lazer como direito social}

O turismo, historicamente e enquanto fenômeno contemporâneo, apresenta-se como uma das mais atraentes e distintivas manifestações de lazer, motivada pela "quebra" da rotina, na busca pela mudança de paisagens, hábitos e ritmos de vida e o contato com diferentes tradições e costumes.

A ideia de deslocamento físico-espacial, por meio de diferentes representações, ajuda a explicar a concepção de turismo: as viagens e os passeios, individuais ou em grupos (intituladas de excursões), possibilitam que as pessoas olhem para a realidade própria, para a realidade dos outros e da localidade visitada. As experiências turísticas podem gerar compreensão e tolerância a respeito das diferenças culturais, além de responsabilidade e consciência sobre algumas questões, como o consumo, a sustentabilidade e as desigualdades sociais. Por serem fundamentalmente opções de lazer, as práticas supramencionadas podem distender-se para o prazer, para a ampliação das possibilidades de diversão e para a busca desinteressada por conhecimento e transformação pessoal. Como diria o historiador Andre Rauch (2001), sair da rotina é afastar-se da precipitação do cotidiano, questionando seus preconceitos e a lógica muitas vezes desumana e exploratória do mundo do trabalho e das obrigações.

Entre as experiências turísticas, as viagens, ao mesmo tempo em que enfatizam essa "fuga" do cotidiano - diante das demandas da 
modernidade e de um ritmo urbano frenético (URRY, 2001) -, por geralmente durarem mais tempo e proporcionarem deslocamentos mais longos, são mais custosas ${ }^{1}$ e, por conseguinte, mais elitizadas. A Organização Mundial de Turismo (OMT) reforça essa associação do turismo à viagem, que é enxergado exclusivamente pelo prisma tecnocrático e economicista. Por representar os órgãos regulamentadores de muitos países e as grandes empresas e multinacionais do trade turístico, a OMT instituiu uma definição que pudesse abranger seus coligados, concebendo que a experiência, para ser considerada turística, deve acontecer fora dos limites da própria cidade de moradia do indivíduo, ao reforçar as categorias viagem e estadia. A intenção da referida instituição, ao criar limites claros para as categorias turismo e turista, é mensurar a prática, gerando números, obtendo com isso apoio político e circulação de capital, satisfazendo assim seus principais associados.

De forma mais ampla e complexa do que propõe a OMT, alguns autores do campo de estudos do turismo (Gastal; Moesch, 2007; Cheibub, 2009) afirmam que a experiência turística pode sim acontecer dentro da própria cidade - alguns chamam essa atividade de turismo urbano, outros intitulam o ator da ação de turista-cidadão.

Mesmo dentro da própria cidade, por conta da privatização ou da concessão à iniciativa privada, vários equipamentos de lazer são transformados em atrativos turísticos nos municípios brasileiros, de modo que muitos moradores ficam impossibilitados de acessar esses espaços em virtude do valor dos ingressos. Nesse contexto, o tecido urbano passa a ser largamente acessível para quem vem de longe, os turistas, e extremamente limitado para a população local de baixa renda, que está à margem do desfrute desses ambientes. Todos os espaços de lazer da cidade, incluindo os atrativos turísticos, deveriam ser gratuitos, acessados livremente pelas pessoas que ali moram. Com esse entendimento, considero o lazer um direito social e, acima de tudo, um serviço público, que deve ser efetivado por políticas públicas que tornem os locais plenamente democráticos (Cheibub, 2015). Infelizmente o poder público municipal tem escolhido um caminho mais "fácil": o do cerceamento dos espaços e a cobrança de ingressos com preços elevados para não ter que lidar com planejamento e educação para o lazer (Melo, 2003). Pensar no turista

1 Em sua maioria, envolvem gastos com pernoite, transporte aéreo, alimentação, ingressos de eventos e de atrativos nos destinos visitados, entre outros custos. 
antes do morador e planejar o turismo antes de delinear o lazer, trocando o planejamento público por estratégias de negócios lucrativos, é encarar a cidade como uma empresa (HARVEY, 2005; VAINER, 2013), em que os interesses do capital se sobrepõem ao bem-estar e à qualidade de vida dos cidadãos.

Na esfera pública federal brasileira, durante os quatro mandatos presidenciais que ocorreram entre 2003 e 2016, apresentou-se como princípio político a social-democracia, baseada, resumidamente, em formulação e execução de políticas públicas sociais em diversas áreas, com o intuito de diminuir as injustiças e as desigualdades sociais oriundas do sistema econômico capitalista (CARvalHo, 2007). O turismo, concebido enquanto possibilidade de lazer e de acesso a outras culturas e ambientes, não exibiu o mesmo avanço que áreas também relacionadas ao campo do lazer, como o esporte e a cultura, sem falar da educação, da saúde, da moradia e da assistência aos desamparados ${ }^{2}$, que receberam investimentos públicos consideráveis desde 2003.

O turismo no setor público brasileiro, de maneira geral, tem sido visto como um braço de ministérios e de secretarias mais associadas à infraestrutura, transportes e comércio ${ }^{3}$, sendo compreendido unilateralmente como atividade econômica geradora de renda e lócus de empregos, estes muitas vezes incontínuos e mal remunerados, absorvendo e estimulando a baixa qualificação de mão de obra (CHeıbub, 2014). O aumento no acesso ao turismo, nos últimos dezesseis anos, por parte considerável da população brasileira, está relacionado às seguintes circunstâncias:

- o vultoso aumento de renda do povo brasileiro, de todas as classes sociais ${ }^{4}$;

- o empreendedorismo ocorrido a partir da diversificação das linhas de crédito, fruto do crescimento da economia, o que ajudou a gerar a inicial expansão de albergues, campings e

2 Assim como o lazer, direitos sociais garantidos pela Constituição Federal Brasileira e concretizados especialmente com o desenvolvimento de alguns programas do governo federal, como o Fome Zero, o Bolsa Família, Minha Casa Minha Vida, as ações afirmativas nas universidades públicas, entre outros.

3 Esse entendimento manteve-se mesmo após a criação do Ministério do Turismo, fundado em 2003.

4 De acordo com Adalberto Moreira Cardoso (2010), aproximadamente cem milhões de pessoas melhoraram significativamente a qualidade de vida no país. 
pousadas (notadamente meios de hospedagem com preços mais acessíveis), o barateamento coletivo das companhias aéreas e a ampliação do acesso à internet por meio da difusão de sites e aplicativos, gerando o barateamento da intermediação, da oferta e de demais serviços turísticos (CHeIbub, 2014).

\section{0 turismo social}

O turismo social tem contribuído, por meios de instituições privadas e públicas espalhadas pelo mundo, para que pessoas que apresentam algum tipo de limitação (especialmente a financeira) desfrutem da experiência turística. No entendimento do Comitê Econômico e Social Europeu:

Todos têm direito de descansar diariamente, semanalmente e anualmente, bem como direito ao tempo de lazer que lhes permite desenvolver todos os aspectos da sua personalidade e de sua integração social. Claramente, todos podem exercer esse direito ao desenvolvimento pessoal. O direito ao turismo é uma expressão concreta desse direito mais amplo, e o turismo social é impulsionado pelo desejo de garantir que ele seja universalmente acessível na prática [EESC, 2006, p. 68, tradução minha].

Esse fenômeno, em vários países europeus e latino-americanos, é majoritariamente desenvolvido pelo poder público, diferentemente do Brasil,

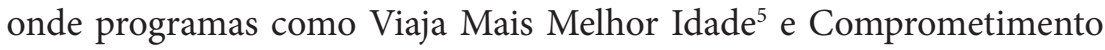
com a Gratuidade $(\mathrm{PCG})^{6}$ não conseguiram decolar, ainda que fossem eivados de potencial e boas intenções. No país, o turismo social é tonificado pelo Terceiro Setor ${ }^{7}$. A instituição brasileira mais associada a essa

5 Esse programa, que teve sua primeira edição lançada em 2007 pelo governo federal, oferece descontos para idosos em transportes e serviços turísticos.

6 Firmado em 2008, o PCG, a partir de uma parceria do governo com a Confederação Nacional do Comércio e o SESC, busca proporcionar um percentual das atividades desenvolvidas pelo SESC de maneira gratuita à população de menor renda.

7 O Terceiro Setor "é composto de organizações sem fins lucrativos, criadas e mantidas pela ênfase na participação voluntária, num âmbito não governamental, dando continuidade a práticas tradicionais de caridade, da filantropia e do mecenato e expandindo o seu sentido para outros domínios, graças, sobretudo, à incorporação do conceito de cidadania e de suas múltiplas manifestações na sociedade civil” (FERnANDEs, 1996, p. 27). 
prática é o Serviço Social do Comércio (SESC), que oferece, desde 1948, oportunidades de lazer turístico aos trabalhadores do setor comerciário. Apresentando intencionalidades díspares, universidades, organizações não governamentais (ONG’s), associações de classe e sindicatos também colaboram com a oferta de experiências turísticas para alguns segmentos da sociedade, por meio de projetos sociais e outras ações, facilitando o acesso para pessoas com limitações de diversas ordens.

Como as instituições que fazem turismo social não visam ao lucro, a questão de financiamento é relevante. Para o SESC, por exemplo, mesmo levando em conta as diferenças orçamentárias entre as administrações regionais, o recurso econômico não é um problema. A instituição recebe $1,5 \%$ da folha salarial de todos os empregados do setor de comércio e serviços, uma obrigação definida por lei federal (FIgueiredo, 1991). Já algumas organizações sem fins lucrativos são erigidas estrategicamente por empresas que lhes transferem recursos, intentando vantagens e/ou incentivos fiscais. Corporações privadas, geralmente quando cunham projetos sociais inseridos em um discurso de responsabilidade social, têm como finalidade principal melhorar a própria imagem perante a sociedade, gerando lucratividade e outros benefícios.

\section{0 projeto de extensão "Turismo social UFF"}

Depois de investigar acerca do turismo social durante aproximadamente dez anos ${ }^{8}$, em 2015 resolvi criar na Universidade Federal Fluminense (UFF) um projeto de extensão inicialmente chamado de "Turismo social para servidores e alunos da UFF", com o objetivo preliminar de oferecer passeios gratuitos à comunidade acadêmica da universidade, tendo como foco a difusão do conhecimento para os alunos associados e outros pares ${ }^{9}$. Foram realizados até o momento diversos

8 Em minhas pesquisas de mestrado (2008-2009) e de doutorado (2011-2014), tive a chance de conhecer um pouco mais sobre o turismo social desenvolvido pelo SESC, suas ideologias e ações.

9 Durante minha pesquisa de campo no doutorado, soube de um projeto de extensão na Universidade de São Paulo (USP) - similar ao que viria a ser o "Turismo social UFF" - intitulado "Rosa dos ventos", criado em 2001 por alunos de turismo da Escola de Comunicação e Artes. Alguns deles posteriormente se transformaram em renomados pesquisadores de turismo e/ou profissionais coordenadores do turismo social em importantes entidades (CAstro, 2016). 
passeios para as cidades de Niterói, Rio de Janeiro, Petrópolis, Maricá, Cabo Frio, Saquarema e Itatiaia, trabalhando conteúdos para além dos "muros" da instituição.

Acredito que a extensão é a dimensão mais admirável na universidade, que não a deixa enclausurar-se na famosa "torre de marfim", lugar para o qual alguns setores e áreas científicas da academia invariavelmente se encaminham, fazendo questão de reforçar a segmentação entre senso comum e científico, explorando debates que não contêm qualquer relação com a realidade. Extensão significa trocar conhecimento com as demandas da sociedade, caminhando com o ensino e a pesquisa, sempre atrelado à construção de uma ideia democrática de ciência, como meio e fim. Infelizmente, por possuir menos prestígio e holofote, a extensão recebe muito menos fomento e incentivo, e consequentemente engajamento dos professores.

Para o referido projeto, são disponibilizadas pela Pró-Reitoria de Assuntos Estudantis (ProAes), desde 2016, cinco bolsas para estudantes de graduação da universidade. Em 2017, mais uma bolsa mensal de custeio foi oportunizada para cobrir os gastos do projeto. Nesse mesmo ano, o projeto passou a se chamar "Turismo social UFF", buscando uma atuação mais ampliada, para além do atendimento a servidores e estudantes da instituição, da qual falarei mais adiante.

Há reuniões semanais com os alunos bolsistas e voluntários que queiram participar, visando organizar e debater desde a dimensão política do turismo social até suas práticas operativas (CHeibub, 2018): a linguagem comunicativa e as diferentes maneiras de perpetrar a divulgação; a escolha e a construção do roteiro (quais atrativos turísticos eleger); o contato com a comunidade e os lugares visitados; a política da UFF e sua relação com o subsídio financeiro (os significados e intencionalidades anexos à questão da imagem institucional). A mediação das experiências, mais conhecida na área turística como guiamento, também abrolha questões relevantes, gerando debates e iniciativas em torno do modo como mediar a relação entre os sujeitos que vivenciam o turismo, e destes com os diferentes espaços, experiências e conteúdos (CHEIBUB, 2018). Nas reuniões, além de os alunos aprenderem a organizar as tarefas operacionais, constantemente há debates sobre o fenômeno do turismo social, apoiados em artigos acadêmicos e exemplificados pela realidade do projeto - as dificuldades, os questionamentos, as conquistas. Em reportagem sobre o projeto no boletim estudantil mensal da PROAES, uma 
ex-bolsista relatou a importância de participar do "Turismo social UFF" para a sua formação acadêmica:

Me ajudou a relacionar os diferentes conteúdos, desde política pública, organização de roteiros, gestão financeira, antropologia, marketing e entre outros. Percebi que colocar essas teorias em prática não é fácil, mas os diferentes temas debatidos nos encontros facilitam a compreensão das teorias estudadas, creio também que o projeto promove uma interação entre os alunos de diferentes cursos. Esses aspectos me mostraram a importância de uma formação plural [Proaes, 2017, p. 9].

Reforçando o comentário exposto, há uma pluralidade de formações entre os integrantes do projeto: para além do bacharelado em turismo, já passaram pelo “Turismo social UFF” estudantes de cinema, serviço social, letras e ciências econômicas, contribuindo para uma construção interdisciplinar que certamente enriquece as ações do projeto.

Diferentemente da realidade da maioria dos projetos de extensão, o apoio que o projeto recebeu da ProAes a partir de 2016 foi e é significativo - é considerado, entre alguns outros projetos, de interesse estratégico da universidade. Contudo, ocasionalmente ocorrem no cotidiano do grupo discordâncias em relação a alguma orientação prévia oficial, em uma espécie de "ética da dissidência". A pró-reitoria, na época da concessão das bolsas, sugeriu que não fossem incluídos como beneficiários do projeto os trabalhadores terceirizados na $\mathrm{UFF}^{10}$, justificando o pedido com uma alegação jurídica: o receio de que eles pudessem reivindicar vínculo empregatício, já que um serviço estava sendo ofertado aos "funcionários" da instituição. Uma das premissas principais no turismo social é oferecer a oportunidade para aqueles que apresentam maiores dificuldades em desfrutar desse lazer. Os terceirizados são os trabalhadores com menor remuneração, além de não terem sindicatos que os representem e defendam seus direitos, estando mais propensos à exploração, a condições laborais precárias e menor estabilidade no emprego. Por isso, quando se inscrevem em um dos passeios, têm merecidamente precedência. Mesmo a mudança do nome do projeto para "Turismo social UFF” foi gestada para abarcá-los.

10 Funcionários contratados por empresas terceirizadas, que realizam majoritariamente serviços de limpeza, segurança e, ocasionalmente, secretariado administrativo. 
Uma das questões mais relevantes nas ações de turismo social em geral diz respeito ao processo seletivo: quem tem prioridade, porque apresenta dificuldade maior para acessar e conhecer os diferentes espaços de lazer da cidade. No “Turismo social UFF” não é diferente: são, em média, quatrocentos inscritos em cada um dos quatro ou cinco passeios realizados por ano, sendo selecionados aproximadamente quarenta (número de assentos disponíveis do ônibus da UFF). Conforme mencionei antes, quando qualquer terceirizado se inscreve, ele tem preferência. No caso dos servidores, segue-se a renda como critério principal. Já para os alunos, realiza-se uma espécie de debate "eterno". O grupo tem compreendido que estudantes que chegaram ao ensino superior valendo-se de ações afirmativas, recebendo algum tipo de assistência estudantil por serem considerados em situação de vulnerabilidade e risco social, obtêm prioridade. Ainda assim, dentro desse universo apresentam-se nuances: alunos de cotas raciais, ações afirmativas de baixa renda, universitários que recebem bolsa de desenvolvimento acadêmico, auxílio moradia, auxílio transporte etc.

Não engessamos os supostos critérios de escolha, e sim aprendemos com as demandas de cada processo seletivo, ou seja, são conjecturas constantemente em aberto, pois o debate da inclusão social é contínuo na envergadura do projeto. Algumas situações nos educam, nos fazem refletir, e um exemplo é o caso de uma aluna que estaria impossibilitada de participar de determinado passeio se não pudesse levar consigo o filho de 5 anos. Sem saber dessa limitação, um dos bolsistas seguiu a diretriz do projeto que não permite acompanhantes em virtude da enorme demanda de inscritos diante da disponibilidade de vagas. A seguir, reproduzo a parte final do conteúdo enviado pela estudante via $e$-mail ${ }^{11}$, o que nos fez mudar de postura e consentir a companhia do filho no passeio em questão: "Igualdade de critérios para todos indiscriminadamente é diferente de equidade. Sem equidade, os grupos marginalizados e minorias sociais saem prejudicados. O que vocês estão propondo é uma falsa igualdade indiscriminada até no caso de mães de filhos pequenos". Esse fato mostrou que, por mais que tenhamos construído critérios que orientam a escolha, é preciso ouvir e conhecer um pouco mais da realidade do indivíduo, com atenção e acuidade, buscando tomar uma decisão da

11 A estudante autorizou por endereço eletrônico que sua frase fosse reproduzida neste trabalho, ao assinar o termo de compromisso. 
forma mais justa possível. O processo seletivo é uma tentativa contínua de apreender quem, a priori, se distancia mais fortemente dessa opção de lazer, vinculando sua realidade financeiro-econômica a sua história de vida, além de considerar sua configuração familiar do momento e demais particularidades da situação. Alguns dos alunos permanecem durante toda a sua vida acadêmica em situação de vulnerabilidade social, por isso é justo que tenham a chance de acessar e conhecer novos lugares. É bem verdade que o fato de terem conseguido adentrar em uma universidade pública federal, de qualidade e gratuita, já opera novos horizontes. Contudo, ratifico a importância de projetos como o "Turismo social UFF", que intentem socializar manifestações culturais, educacionais e de lazer, colaborando com o enfrentamento dos discentes diante de algumas barreiras simbólicas que ainda existam no seu universo de possibilidades.

\section{As mediações do/no projeto}

Como ajudar na relação que se estabelece entre as pessoas e as experiências, o conhecimento e a informação, sem ser maçante? Como provocar prazer, reflexões, desnudando a realidade, as disputas de poder, as complicações, os entraves e as peculiaridades do que se está observando? No guiamento clássico, o guia enxerga a realidade de forma vertical, entabula uma série de conteúdos prontos, independentemente da vontade, dos anseios e dos prazeres das pessoas do grupo (CARIDE, 1997). Lembro-me de um dado marcante que envolveu minha pesquisa de mestrado, sobre um projeto do SEsc intitulado "Turismo jovem cidadão", que oportunizava a experiência turística para adolescentes pobres de comunidades situadas em torno de algumas unidades da entidade. Ao serem perguntados sobre o lugar que tinham mais gostado, todos deram a mesma resposta: o ônibus da excursão. Era o único local em que eles se sentiam libertos do conteúdo tedioso do guia, do constrangimento de como deveriam se portar, agir, como e quantas fotografias deveriam tirar etc. (Cheibub, 2009). Por mais que o documento escrito da proposta tivesse como um de seus objetivos "ampliar as possibilidades de lazer dos participantes", a forma como os passeios eram construídos e mediados - com vários afazeres e obrigações, norteados por um guiamento conteudista, catedrático, resignado - fazia com que os jovens não vissem aquela experiência como lazer, todos até mesmo a chamavam de "escola" (Cheibub, 2009). 
Diferentemente do guiamento tradicional, adota-se no projeto “Turismo social UFF” a filosofia nutrida pela animação cultural, uma tecnologia pedagógica que apresenta algumas particularidades (Melo; Cheibub, 2010):

- $\quad$ enxerga a realidade de maneira horizontal, realizando atividades com o grupo e não para o grupo, unilateralmente;

- trabalha com uma ideia radical de mediação e negociação, e nunca de imposição;

- desenvolve o conceito de circularidade cultural, no qual todos são considerados produtores e consumidores de cultura, podendo encarar a cidade como um grande equipamento multicultural de trocas e arranjos diversos;

- busca incessantemente o protagonismo social dos sujeitos, colaborando a tornarem-se protagonistas de suas próprias escolhas.

Já o animador cultural tem como objetivos (Melo; Cheibub, 2010):

- não precisar existir, ao contribuir com a autonomia dos indivíduos, que não precisam constantemente de um profissional guiando sua experiência, detentor da verdade, ditando regras e formas de como se comportar;

- $\quad$ inversamente ao modelo "clássico", envolver o grupo, trazendo questões, levantando reflexões, sem necessariamente dar respostas, mas endereçando e instigando um olhar agudo, crítico sobre a realidade e ao mesmo tempo prazeroso, lúdico, o que torna a experiência em si revolucionária;

- trabalhar considerando constantemente a história de vida das pessoas, suas experiências, suas tradições, seu conhecimento sobre as coisas.

Nas escolhas do grupo de bolsistas e colaboradores do projeto, elegemos lugares levando em conta as histórias de vida, experiências e desejos. Antes de tudo, por uma questão de princípio, buscamos sempre a gratuidade em todos os atrativos, priorizando aqueles que recebem os visitantes de forma democrática e não preconceituosa. Tentamos evitar locais que entabulem guiamentos obsoletos. 
Ao planejar o roteiro, o que é proposto? Geralmente, quando enxergamos possibilidades, abraçamos os princípios do chamado turismo de base local ou comunitária, que representa "uma proposta de desenvolvimento apoiada na conservação ambiental, na valorização da identidade cultural e na geração de benefícios diretos para as comunidades receptoras" (Costa et al., 2012, p. 546). No município de Maricá, Rio de Janeiro, fomos a uma aldeia indígena sob o risco de reintegração de posse e ouvimos um dos integrantes do povoado contar as dificuldades na tribo e na relação com o poder público local. Claramente, o embasamento comunitário também esteve presente nas visitas à Zona Portuária do Rio, quando incluímos no roteiro instituições de luta em prol de movimentos sociais relevantes da região, podendo ouvir o ponto de vista dos moradores em questões importantes, como a dimensão política e as disputas de poder, os problemas cotidianos, ou seja, a realidade social do local, que recentemente passou por um processo de turistificação na esteira dos megaeventos sediados na cidade, sofrendo com desalojamentos e outras ações coercitivas do Estado. Em Niterói, levamos os funcionários e alunos da UFF ao MACquinho - construção de Oscar Niemeyer acoplada ao Morro do Palácio, favela da Zona Sul do município -, sede da Plataforma Urbana Digital, um projeto da Secretaria de Educação, Ciência e Tecnologia da prefeitura de Niterói, trabalhando arte, mídias digitais e inclusão social com os jovens da referida favela. A fala de um dos turistas entrevistados, após a vivência, reforça essa faceta comunitária e social do projeto $^{12}$ :

$\mathrm{Eu}$ gostei também da escolha dos lugares. Inclusive, aqui em Niterói, uma coisa que me surpreendeu é que sempre mostram o MAC. Não tô dizendo que tenha que tirar o MAC, mas eu nunca soube, nem me falaram do MACquinho. Então, no momento em que nos levaram até lá, teve a oportunidade de conhecer o outro lado, inclusive até a visão é outra que você tem da cidade. Eu acho que isso contribuiu muito porque, se vocês fizessem um passeio apenas com os pontos já marcados, é bom, você tem que fazer, é óbvio, mas talvez teria sido cair no senso comum e nem entrar em um olhar mais crítico, trazer uma coisa mais crítica.

$12 \mathrm{O}$ entrevistado aceitou ser referenciado, assinando o termo de compromisso. 
Nem sempre temos a chance de adotar essa gradação de base local ou comunitária. Dependendo da cidade, atemo-nos aos atrativos tradicionais, sem culpa, mostrando aquilo que de mais atraente e divertido há, mesmo que não seja gerido pela comunidade do lugar. Não obstante, mesmo nesses destinos tentamos problematizar suas relações locais, às vezes ocultas, enxergando-as por dessemelhantes prismas, diferentemente de algumas agências, que orientam seus guias a só contar uma versão da história, geralmente a mais cordata e menos polêmica.

Outra característica que difere o turismo social frontalmente das práticas de uma parte considerável do mercado das agências de turismo diz respeito à relação com o que chamamos de fornecedores, "parceiros" que colaboram com diferentes serviços para que o passeio aconteça no projeto “Turismo social UFF": além dos atrativos, há o transporte rodoviário, a corretora do seguro-viagem, o restaurante e as distribuidoras de produtos alimentícios para a confecção do kit lanche. Por conta da menor pressão orçamentária sofrida e menos preocupação com a obtenção de lucro e receita ${ }^{13}$, a oportunidade de "educar" os fornecedores tem maior chance de acontecer pelos bolsistas do "Turismo social UFF". Constantemente solicitamos para o setor de transportes da UFF a melhoria estrutural dos ônibus, que ocasionalmente estão sem cinto de segurança em alguns dos assentos. Também tivemos problemas com uma guia local de um dos atrativos da cidade de Petrópolis, que fora ríspida com o grupo de turistas, sem motivo aparente; no papel de instituição pública de educação, enviamos um e-mail formal à coordenação do estabelecimento relatando o fato, buscando o aprimoramento do atendimento para futuros visitantes. O seguro-viagem para todos os participantes da excursão também é uma responsabilidade que não passa despercebida, diferentemente de algumas empresas de agenciamento turístico, que não o fazem para a totalidade dos passageiros, buscando economizar.

\section{Problematizando o projeto}

Muitas questões mencionadas anteriormente aparecem nos exercícios etnográficos que os discentes bolsistas/colaboradores do projeto constroem após cada passeio, descrevendo livremente suas percepções

13 Geralmente o ganho financeiro não é o objetivo principal das agências e instituições que realizam o turismo social. 
críticas em relação a tudo de importante que, na visão de cada um, aconteceu; lemos e debatemos esses relatos coletivamente na reunião que sucede a cada passeio realizado. A pesquisa de satisfação feita com os funcionários e estudantes da UFF ao final da excursão também é problematizada nesse momento, com a ajuda da tabulação criada por uma das bolsistas. Ao final de 2017, duas bolsistas de desenvolvimento acadêmi$\mathrm{Co}^{14}$, orientadas por mim, realizaram entrevistas com os turistas que estiveram nos passeios em 2016 e no primeiro semestre de 2017, buscando saber se o acesso à experiência turística trouxera contribuições efetivas para a vida deles.

Alguns comentários espontâneos que recebemos durante e após os passeios circundam exemplos de caraterísticas utilitaristas do lazer, enxergado como instrumento de desenvolvimento pessoal e social (Marcellino, 1987). Como exemplos: duas mulheres que sofriam de depressão relataram que a experiência turística ajudou impulsionando nelas a vontade de querer sair de casa e voltar a socializar-se com outras pessoas; duas jovens conseguiram estágio em um dos equipamentos culturais, após conversarem com o coordenador na ocasião da visita. Não questiono a relevância utilitarista do lazer em nossa sociedade, mas não acho essas histórias necessariamente mais importantes que a de pessoas que simplesmente proferiram: "Foi ótimo, senti prazer, gostei, fiquei feliz, me deu vontade de voltar, de retornar com os amigos e familiares, de conhecer mais lugares, etc."

Quando em 2017 passamos a contemplar mais estudantes pobres em detrimento dos servidores, ao final do primeiro passeio, após dinâmica de compartilhamento realizada por uma bolsista-mediadora, ouvimos os agradecimentos e sentimos a gratidão dos alunos, algo que não havia acontecido até aquele momento. Na bibliografia sobre a história do turismo social (CHeIbub, 2014; FALCÃo, 2006; BARANowsky, 2004), encontramos que a gratidão que os trabalhadores beneficiados pelas atividades recreativas - ocasionalmente turísticas - sentiam era usada como "moeda de troca" para inculcar diferentes ideologias oriundas de governos totalitaristas durante quase toda a primeira metade do século $\mathrm{xx}$, em

14 A bolsa de desenvolvimento acadêmico é ofertada a alunos considerados em situação de vulnerabilidade social, que, após a receberem, escolhem um dos projetos associados, tendo tarefas envolvidas com o acompanhamento de seus estudos e a iniciação científica. 
nações europeias e sul-americanas ${ }^{15}$. No projeto "Turismo Social UFF”, o agradecimento genuíno e a retribuição em forma de felicidade concreta dos beneficiados trouxe um sentimento bom; no entanto, diferentemente dos exemplos assistencialistas supracitados, não nos aproveitamos da situação para receber algum tipo de benefício, pedir para acreditarem em determinada ideologia ou os manterem dependentes do projeto de alguma forma, características de um populismo assistencial.

Essas questões trazidas no parágrafo anterior são ainda mais candentes na relação construída, desde meados de 2017, com o Centro de Referência Especializado para População em Situação de Rua (Centro Pop) de Niterói, uma unidade pública que trabalha com assistência social, conveniada ao projeto $^{16}$, por meio da iniciativa de duas alunas do bacharelado em serviço social da UFF, que mediaram o encontro entre as partes. Desde então foram realizados dois passeios com os titulados "usuários" do Centro Pop: um no Museu de Arte Contemporânea, em Niterói (novembro de 2017), e outro no famoso cartão-postal carioca Pão de Açúcar (maio de 2018). Retornando ao debate feito no início do capítulo, a junção de turistas estrangeiros ou brasileiros - em sua maioria brancos, ricos ou de classe média alta - frequentadores constantes desses lugares e de moradores em situação de rua, aos quais geralmente é vedado o acesso, tem balançado algumas estruturas sociais, muitas vezes convenientemente engessadas. O contato com pessoas nessa condição gera concretamente mudança de mentalidade nos integrantes do projeto, que por sua vez ajudam a efetivar o direito à cidade e ao lazer para indivíduos

15 Tem-se como exemplos a Alemanha nazista de Hitler, a Itália fascista de Mussolini, a União Soviética socialista de Stalin, a Argentina de Perón, o Brasil de Vargas, entre alguns outros países.

16 Dois outros convênios foram construídos em 2018. Um envolvendo a população idosa, público historicamente relevante para a tonificação do fenômeno do turismo social em diversos países; organizamos uma experiência turística com um grupo de serviço de convivência e fortalecimento de vínculos para pessoas idosas do Centro de Referência de Assistência Social (CRAs) do Barreto, bairro de Niterói, posto responsável por coordenar atividades assistenciais, atendendo famílias que careçam de auxílio social naquela imediação. Outro convênio busca a autonomia e o alcance da melhoria das condições de vida de pessoas com transtornos mentais, promovendo atividades sociais; realizamos um passeio com as pessoas assistidas pelo Centro de Convivência e Cultura: Oficinas Integradas do Programa de Saúde Mental (PSM) da Fundação Municipal de Niterói. 
que não possuem sequer direitos civis básicos. Nos encontros e eventos realizados na entidade, as assistentes sociais, psicólogas e pedagogas do Centro Pop têm nos contado da alegria radiante dos usuários ao retornarem dos passeios, construindo ideias, planos e novos horizontes de vida. Em 2018 foi realizada a exposição itinerante Cotidiano sem muros - o olhar do invisível, na UFF e no MACquinho, com as imagens fotografadas por eles nos passeios, emolduradas por material reciclado retirado do lixo, trabalho também realizado pelos usuários do Centro Pop.

\section{Considerações finais}

Tão ou mais importante que o direito reconhecido é o direito efetivado, qualificado e diversificado; não adianta o lazer ser um direito social se a variedade de possibilidades que o conformam não faz parte do cotidiano, dos hábitos e dos costumes de um número considerável de pessoas (Снеiвub, 2014), notadamente as coletividades que sofrem processos de estigmatização e de discriminação, derivando em várias formas de desigualdade, exclusão e injustiças sociais (ARENDT, 2008).

Além de ser uma prática social e um mediador do encontro entre diferentes culturas, por meio das experiências humanas que acontecem em seu bojo, o fenômeno do turismo social contribui para que a opção de "sair do seu cotidiano" seja mais habitual na vida de diversos indivíduos e grupos (Cheibub, 2014). Ao alargar as possibilidades de lazer no variado espaço da cidade e nas diferenças culturais que nela brotam, os indivíduos têm a chance de percebê-la como campo de construção da sua identidade e das relações humanas que a permeiam (CHEIBub, 2009). As "boas" práticas de turismo social, configuradas geralmente por passeios em grupos (excursões) com a duração de um dia, têm colaborado para que o acesso à urbe aconteça de forma mais lúdica e democrática.

\section{Referências}

Arendt, H. Compreender: formação, exílio e totalitarismo. São Paulo: Companhia das Letras, 2008.

BARANOWsky, S. Strenght through joy: consumerism and mass tourism in the Third Reich. New York: Cambridge University Press, 2004.

Cardoso, A. M. A construção da sociedade do trabalho no Brasil. 1. ed. Rio de Janeiro: FGV, 2010. v. 1. 
CARIde, J. A. Paradigmas teóricos en la animación sociocultural. In: Trilla, J. (Org.). Animación sociocultural: teorias, programas y ámbitos. Barcelona: Ariel, 1997. p. 40-60.

Carvalho, J. M. Cidadania no Brasil: o longo caminho. 9. ed. Rio de Janeiro: Civilização Brasileira, 2007.

Castro, M. G. Rosa dos ventos: turismo social para crianças e sua relação com o turismo pedagógico. 2016. Trabalho de Conclusão de Curso (Graduação em Turismo) - Universidade Federal Fluminense, 2016.

Cheıbub, B. L. Lazer, experiência turística, mediação e cidadania: um estudo sobre o projeto Turismo Jovem Cidadão (SESC-RJ). 2009. Dissertação (Mestrado em Estudos do Lazer) - Universidade Federal de Minas Gerais, 2009.

Cheıbub, B. L. A história do "turismo social" no Serviço Social do Comércio SP. 2014. Tese (Doutorado) - Programa de Pós-Graduação em História, Política e Bens Culturais, Cpdoc/FGV, Rio de Janeiro, 2014.

Cheibub, B. L. As contribuições da produção científica para o entendimento do lazer como direito social. In: Gomes, C. L.; Isayama, H. F. (Org.). O direito social ao lazer no Brasil. 1. ed. Campinas: Autores Associados, 2015. p. 201-227.

Cheibub, B. L. Mobilidades, lazer e turismo social - MobLaTus (PPGTUR/ UFF). In: Uvinha, R. R. (Org.). Lazer no Brasil: grupos de pesquisa e associações temáticas. Editora SESC, 2018.

Costa, H. A.; Fabrino, N. H.; Nascimento, E. P. Turismo de base comunitária (TBC): elementos chaves para aferir seu desempenho na perspectiva da sustentabilidade. Revista Brasileira de Ecoturismo, São Paulo, v. 5, n. 3, p. 546-559, 2012.

EESC - European Economic and Social Committee. Opinion of the Economic and Social Committee on social tourism in Europe. Brussels: EESC, 2006.

Falcão, C. H. P. Turismo social: em busca de maior inclusão da sociedade. In: Carvalho, C. L.; Barbosa, L. G. M. (Org.). Discussões e propostas para o turismo no Brasil. Rio de Janeiro: Senac Nacional, 2006. p. 127-145.

Fernandes, R. C. Privado, porém público: o terceiro setor na América Latina. 2. ed. Rio de Janeiro: Relume Dumará, 1996.

Figueiredo, B. G. A criação do Sesi e Sesc: do enquadramento da preguiça à produtividade do ócio. 1991. Dissertação (Mestrado) - Faculdade de História, Universidade Estadual de Campinas, 1991. 
Gastal, S.; Moesch, M. Turismo, políticas públicas e cidadania. São Paulo: Aleph, 2007.

Harvey, D. A produção capitalista do espaço. São Paulo: Annablume, 2005.

Marcellino, N. C. Lazer e educação. Campinas: Papirus, 1987.

Melo, V. A. Lazer e minorias sociais. São Paulo: Ibrasa, 2003.

Melo, V. A.; Cheibub, B. L. Experiência turística, ocio/recreación y mediación: un estudio del proyecto "Turismo Jovem Cidadão" en Rio de Janeiro, Brasil. Estudios y Perspectivas en Turismo, Buenos Aires, v. 19, n. 6, p. 1.037-1.052, 2010.

Proaes - Pró-Reitoria de Assuntos Estudantis. Espaço do bolsista: projeto Turismo Social. Boletim Estudantil, ed. 10, jun. 2017.

Rauch, A. As férias e a natureza revisitada. In: Corbin, A. (Org.). História dos tempos livres. Lisboa: Teorema, 2001. p. 19-58.

URRY, J. O olhar do turista: lazer e viagens nas sociedades contemporâneas. São Paulo: Studio Nobel/SEsC, 2001.

VAIner, C. Cidade de exceção: reflexões a partir do Rio de Janeiro. Anais. In: Encontro Nacional da Associação Nacional de Pós-Graduação e Pesquisa em Planejamento Urbano e Regional, 14., 2013, Rio de Janeiro. Anais... Rio de Janeiro: Anpur, 2013. 



\title{
CAPÍTULO 14
}

\section{MEMORIAL MINAS GERAIS VALE: O LAZER EM UMA INSTITUIÇÃO MUSEOLÓGICA}

\author{
Larissa Maria Santos Altemar
}

Pamela Emilse Naumann Gorga

\section{Lazer e museus: experiências contraditórias?}

Reitero que museu é também lugar de sonho, do devaneio, do lúdico, da informação, da comunicação, das experiências, da sensibilidade, da autoimagem e de muitíssimas outras funções simbólicas e pragmáticas, que escapam completamente às perspectivas de meu texto . Meneses, 2013, p. 57

Ao falarmos sobre lazer, a primeira ideia, reflexo do senso comum, seria relacioná-lo a locais como shoppings, clubes, a eventos como shows, festas, ou ainda a viagens - espaços e tempos que o sujeito é convidado a ocupar de forma passiva e às vezes menos reflexiva. Logo, o lazer nesses espaços estaria ligado ao descanso, quando nenhum tipo de labor, exercício ou atividade densa deveria ser requerida. Por isso questionamos: Seria o museu um espaço de lazer? Será que o dito espaço cultural pode ser considerado uma alternativa no leque de opções que se apresenta diante da oportunidade de aproveitarmos o tempo livre? Porventura, podemos nos aproximar do conhecimento ao mesmo tempo em que nos afastamos da noção de trabalho (como um exercício que exige atenção)? Seriam essas experiências, museus e lazer, excludentes?

Ao pensarmos em museus, torna-se necessário ressaltar o contexto de seu surgimento, pois essas instituições são fruto de uma proposta bem 
diferente do seu objetivo atual, considerando que em sua conjuntura não eram espaços compreendidos como um possível local de lazer. Em sua origem, os museus nasceram como "gabinetes de curiosidades", concebidos segundo um caráter enciclopedista, para resguardar a memória e as exóticas descobertas do Novo Mundo. Por isso, nos séculos XVII e XVIII começaram a surgir coleções, principalmente sob mecenatos de importantes famílias, e, embora esses acervos em sua maioria pudessem ser visitados - isso graças a uma carta de apresentação -, não devemos menosprezar o fato de que eram uma possessão privada. Como tal, não existia consenso na sistematização e organização do material; grosso modo, havia duas grandes seções: Naturalia, que comportava os reinos vegetal, animal e mineral, e Mirabilia, que guardava as invenções, assim como diversos materiais de culturas distantes (GonçAlves Possas, 2013). Aliás, na atualidade ainda persiste o imaginário de que museu é sinônimo de depósito, no qual se entulham objetos ou amostras desses mundos.

Contudo, nesse primeiro momento não estava em discussão o conhecimento científico que podia jazer nesses acervos. Na verdade, a coleção era sinônimo de poder e destaque social: "quanto mais ampla a coleção, em termos quantitativos, maior o status e o poder de seu proprietário" (Gonçalves Possas, 2013, p. 164). Assim, museus funcionavam como "templos" que "homologavam os valores da burguesia" (Meneses, 2013, p. 17).

Entretanto, houve mudanças no decorrer do século XVII, quando a investigação tomou conta desses espaços e proporcionou classificações mais apuradas, e com elas a formação de coleções mais específicas. Por sua vez, essa mudança foi acompanhado por locais mais propícios para a sua exposição, porém novamente esses lugares que abrigavam o conhecimento conferiam status não a quem os frequentava, mas àqueles que os montavam.

Estes espaços serviram para a legitimação de "novos" cientistas, que escreviam e divulgavam seus esforços de estabelecimento de diferentes métodos de classificação, de descoberta de novos espécimes, de contribuições para o entendimento do mundo, muito mais vasto do que se podia supor antes [GonçALVEs Possas, 2013, p. 166, grifo nosso].

Dessa forma, a transformação dos museus ao longo do século XVIII estava atrelada à produção de conhecimento de universidades e de escolas 
superiores. Destarte, a ciência ganhava um novo espaço de divulgação e, paralelamente, a oportunidade de atingir um público maior, além dos cientistas e letrados (Gonçalves Possas, 2013, p. 167).

Até aqui apontamos os artífices daquilo que acabaria gerando, na atualidade, o que conhecemos como museus, isto é, os colecionadores e os cientistas que compilavam e organizavam o acervo e, a passos muito lentos, começavam a abri-los para outros grupos. Mas onde está o público como protagonista desses espaços? Quando a fruição desses locais se tornaria uma preocupação real a ser levada em conta em seu planejamento ${ }^{1}$

Embora já existisse a conscientização da necessidade de atingir o público leigo visitante, criando pontes entre ele e a produção científica ali exposta, dentro do histórico dos museus, apenas na terceira geração - na segunda metade do século $\mathrm{xx}$ - é que esse visitante se torna um "sujeito ativo no processo educativo no museu” (MARANDino, 2008, p. 16). Diante dessa mudança, a interação entre o que é exposto e a forma com que o público se apropria do acervo e, portanto, do conhecimento converte-se no foco da mediação nesses espaços museais/culturais.

Atualmente, a preocupação em tornar a exposição acessível ao público é enfatizada, de maneira que este público a compreenda, tornando-a significativa. É preciso que o visitante seja ativo e engajado intelectualmente nas ações que realiza no museu e que as visitas promovam situações de diálogo entre o público e deste com os mediadores. Para isso, os setores educativos dos museus devem não só planejar bem suas atividades como concebê-las a partir de opções educacionais claras [MARANDino, 2008, p. 16, grifos nossos].

Com isso, o acesso a conteúdos específicos e o diálogo entre todos os agentes no contexto museal tornam-se basilares, o que nos faz questionar: Sendo o museu um espaço que convida o público visitante, em passeio, a ser ativo e a mediar imagens, objetos e tecnologia com seus conhecimentos, podemos considerá-lo um espaço de lazer?

1 “Também considerando que uma das funções da Organização, conforme estabelecido em sua Constituição, é dar novo impulso à educação popular e à disseminação da cultura: colaborando com os Membros, sob sua solicitação, no desenvolvimento de atividades educacionais; instituindo a colaboração entre países para avançar no ideal de igualdade de oportunidades educacionais independentemente de raça, gênero ou quaisquer distinções, econômicas ou sociais; e mantendo, ampliando e disseminando o conhecimento" (UnEsCo, 2015). 
O conceito de lazer, por sua vez, engloba a "valoração de algumas condutas humanas" (Almeida; Gutierrez; Marques, 2008, p. 5) e fixase a partir da consolidação do capitalismo, com a noção de que o tempo livre é substancial para a classe trabalhadora. Essa noção afirma que o sujeito tem seu tempo compartimentado e maioritariamente ocupado com o trabalho (Almeida; Gutierrez; Marques, 2008), compreendendo que a concepção de lazer está associada ao "desenvolvimento tecnológico nas sociedades industriais" e "a sua inserção na dinâmica social" (AlmEIDA; Gutierrez; Marques, 2008, p. 1). Logo, o entendimento sobre o que viria a ser lazer acompanha o desenvolvimento de uma sociedade e, portanto, é algo datado e contextualizado em um período histórico.

o lazer, durante o processo de seu nascimento, passou vagarosamente de um consumo de bens raros e supérfluos de uma classe dominante para algo amplo associado ao consumo de bens materiais culturais e artísticos para todo o coletivo, porque os diferentes grupos sociais exigiriam através de inúmeros meios o seu tempo de lazer [Almeida; Gutierrez; Marques, 2008, p. 10, grifos nossos].

Ora, parece-nos que a concepção de lazer seguiu a mesma lógica das consolidações sobre o espaço museal: em um primeiro momento, estava reservado para os detentores do capital cultural legitimado (burguesia) (Bourdieu, 2007), porém buscou ampliar-se e direcionar-se a diferentes públicos (classe trabalhadora).

Entretanto, o conceito de lazer possui variações, e por isso existem diferentes olhares em torno dele, que se completam e apontam para direções diversas, partindo da mesma pergunta: O que é lazer?

o lazer é um conjunto de ocupações às quais o indivíduo pode entregar-se de livre vontade, seja para repousar, seja para divertir-se, recrear-se e entreter-se, ou ainda, para desenvolver sua informação ou formação desinteressada, sua participação social voluntária ou sua livre capacidade criadora após livrar-se ou desembaraçar-se das obrigações profissionais, familiares ou sociais [DUMAZEDIER, 2001, p. 34, grifos nossos].

Marcellino, em consonância com Dumazedier (2001), convida a olharmos para o lazer como um processo duplo, "veículo e objeto de educação" (MARCELlino, 1998, p. 39), atrelando sossego ao "desenvolvimento pessoal e social" (MARCELlino, 1998). Embora o autor compreenda que cultura e lazer são vivenciados no tempo livre das obrigações 
ligadas ao trabalho, família e estudos, e por isso caracterizam-se mais fortemente como tempo do ócio, ele aponta para a necessidade de uma "reforma moral e cultural que contribua para uma nova ordem social, a ser construída no coletivo" (MARCELlino, 1998, p. 40). O autor defende uma reforma do tempo do lazer que se distancie apenas do consumo, que dê a possibilidade de escolha e efetiva participação aos sujeitos de determinada cultura sobre o seu tempo livre.

Herbert Marcuse, sociólogo e filósofo alemão, desenvolve uma tese que contribui para refletirmos sobre outro aspecto ligado ao lazer: a alienação. Segundo o autor, de fato, não teríamos um tempo verdadeiramente livre: além de significarem uma porção ínfima da nossa rotina, as atividades desenvolvidas nesse período estão cingidas de uma aparente liberdade de escolha. Noutros termos, aquilo que realizamos em nosso "tempo livre", igualmente ao que acontece com o trabalho e a produção, está controlado pela política e pela economia, contribuindo, assim, para a manutenção do poder instituído. A nossa vontade e o nosso ócio encontram-se à mercê da sociedade, que faz com que suas necessidades, interesses e desejos ultrapassem o campo individual. Dessa forma, o indivíduo acaba sendo manipulado pelo entorno, inclusive naquilo que entendemos como "lazer".

Contudo, na medida em que o progresso da alienação desliga ainda mais o indivíduo de sua necessidade, ocorre uma mudança qualitativa na vida do ser humano. Nesse sentido, o próprio lazer também é apreciado por Marcuse como uma possibilidade de interstício para a libertação, e assim o tempo livre torna-se um "domínio do lúdico" (MARCELINo; Nascimento, 2012, p. 33).

Com base em Marcellino e Nascimento (2012) e Marcuse, refletimos: Estaríamos diante de um tempo-espaço de urgência do lazer determinante para a qualidade da vida humana e variante primordial da manutenção das inovações? Haveria, por conseguinte, uma necessidade de interrupção da produção para garantir nossa existência? Em diálogo com esses autores, podemos afirmar: Lazer é questão de vida! Mas, se a "indústria do entretenimento controla diretamente o tempo de lazer" (Marcellino; Nascimento, 2012, p. 34), como podemos contribuir, enquanto instituição museal, para criar possibilidades de escolha dos visitantes nas ações, programação e fruição?

Apoiadas nesses autores, referências na temática do lazer, compreendemos que os conceitos de ocupação, vivência e alienação devem ser 
confrontados com o espaço museal, entendido não como um repositório de objetos ou "gabinete de curiosidades", mas como um campo de discurso aberto, não dogmático, no qual o conhecimento se constrói no diálogo entre os componentes do trinômio: expografia, mediador, público.

Assim, a visita ao museu adquire outros contornos: já não é mais uma experiência passiva, na qual o visitante apenas escuta ou aprecia, pois, embora a visita possa comportar momentos de contemplação, o conhecimento é construído em uma via de mão dupla, "por meio de um processo ativo de negociação de saberes e experiências, no qual todas as partes trabalham em conjunto para produzir interpretações compartilhadas" (Marandino, 2008, p. 17).

Em vista disso, o museu é "um terreno que, ao impor o intercâmbio contínuo e salutar com o público, é atravessado por memórias e construções identitárias formuladas pela sociedade" (Julião, 2006, p. 104), em meio a um contexto social que pede maior "democratização do acesso e uso da informação e do conhecimento" (Julião, 2006, p. 102). Tratase, portanto, de um chamamento ao visitante ao exercício de tradução e decodificação entre as diferentes linguagens expostas no espaço e as inúmeras possibilidades de (re)significar um objeto, uma sala, um som, um vídeo...

Dessa forma, nesse processo de interpretação dos significados contidos no museu é que o Educativo toma centralidade, pois sua missão é incentivar a reflexão e instigar o olhar crítico do público visitante, seja qual for sua faixa etária. Uma vez que compreendemos o museu como instituição que desenvolve, simultaneamente, um papel científico, cultural e educativo em movimento contínuo, a pesquisa (interdisciplinar) surge como um dos pilares de sua existência (Julião, 2006). Essa exploração nos permite ir além da expografia, questionando-a e aproximando-a do público, em um exercício que evita deixar cair o discurso museal em visões dogmáticas e estagnadas.

Ora, essa experiência é necessariamente entediante? Se "o lazer, portanto, é uma forma de conhecer o mundo e sua característica principal é o tempo livre com divertimento, ludicidade e prazer" (AlmeIdA; Gutierrez; Marques, 2008, p. 7), por que uma visita ao museu não pode também ser lúdica e fazer parte de um tempo ou atividade considerada de lazer? Podemos passar um tempo livre, com divertimento e prazer, andando por um prédio republicano, explorando Minas Rupestres, observando a réplica da Casa da Ópera de Ouro Preto, vestindo figurinos 
de personagens da história de Minas Gerais? Ou adentrando a Fazenda Mineira com educadores nos pedindo para contar histórias? Seria possível nos emocionarmos e, ao mesmo tempo, refletirmos sobre a Inconfidência Mineira, ao sermos surpreendidos pelos personagens do levante?

\section{Memorial Minas Gerais Vale: experiências para diversos públicos}

Localizado na Praça da Liberdade, onde antigamente funcionava a Secretaria da Fazenda, o Memorial Minas Gerais Vale (MMGV) integra o Circuito Cultural Liberdade, um complexo de museus gratuitos situados em prédios públicos mantidos por empresas privadas.

O Memorial, especificamente, caracteriza-se como um museu de experiência que, com espaços cenográficos, convida o visitante a vivenciar recortes da história, da cultura e da arte de Minas Gerais. Essa experiência pode ser realizada de forma espontânea ou com mediação. No primeiro caso, o público frui o museu sozinho, em seu próprio tempo, estabelecendo reflexões sem a intervenção de um educador; no segundo, essa figura se faz presente e, utilizando diversas ferramentas, busca intermediar sensações, lembranças e conteúdos entre a expografia, o discurso e o público.

Em quase oito anos de existência, o MMGV tem sofrido notáveis mudanças, principalmente no que diz respeito à inclusão do visitante. Se "uma boa exposição museal é aquela que permite ao visitante se identificar com o objeto observado, possibilitando que a partir dele aflorem conhecimentos e memórias" (CoNsidera, 2015, p. 151), podemos dizer que o trabalho realizado pelo Educativo do Memorial tem se movimentado nessa direção. As pesquisas desenvolvidas pelos educadores buscam construir elos críticos e reflexivos entre a exposição e o público, para que esse último se sinta cada vez mais pertencente ao espaço e, ao mesmo tempo, identifique-se como responsável por esse patrimônio.

Dessa forma, o Educativo vai além da proposta museográfica original, baseada em três temas principais/circuitos de visitação - Minas Imemorial Clássica, Minas Polifônica Multicultural e Minas Visionária - e ainda desenvolve os chamados "Percursos", recortes temáticos adaptados segundo as diversas faixas etárias. Assim, e para o interesse do presente capítulo, selecionamos quatro abordagens (infância, cartografia da memória, república e mineiridades) que contemplam a diversidade de público recebido pelo Memorial, no intuito de compreender como "a 
educação e o lazer são, por definição, finalidade das instituições museológicas" (Chagas, 2009, p. 57).

Falemos, primeiramente, do público infantil. A primeira mediação com crianças pequenas, em 2013, nasceu de uma pergunta aparentemente simples, mas cuja resposta interferiu no planejamento, execução e avaliação da visita: Museu é lugar de criança? Se sim, como recebê-la? ${ }^{2}$ Após muita reflexão e pesquisa, podemos afirmar que a concepção de protagonismo infantil, assim como a de cultura da infância (SARMENTO, 2004; Machado, 2010), tem norteado nosso trabalho, e por isso a recepção do público infantil é pensada no formato das visitas agendadas e das visitas espontâneas. No primeiro caso, buscamos criar uma linha narrativa com a qual a criança experiencie o museu de forma significativa. Assim, por meio de diversos instrumentos e na perspectiva da ludicidade, convidamo-las a "explorar" e "descobrir" o espaço.

Desse modo, por exemplo, dentro da proposta do percurso Africanerê, vários orixás (materializados em fantoches) contam sua função como protetores da natureza. Xangô, como guardião das pedras e pedreiras, recebe-nos na sala das Minas Rupestres, que encena uma caverna; Exu, o protetor da terra e do chão, aguarda-nos na sala do Vale do Jequitinhonha, onde as peças de barro com sua cor característica tingem seus pés; e Ossaim, guardião das folhas verdes e das ervas, conta-nos seus segredos na sala das Fazendas. Podemos, ainda, percorrer o trajeto entre os espaços como uma brisa, como faz Yansã, que chega com o vento e é a guardiã dos raios e das tempestades, ou fruir o espaço como a espuma do mar, do qual Yemanjá é protetora.

Esse caso da exploração da herança africana em Minas Gerais é apenas um dos tantos exemplos do específico trabalho que realizamos com esse público. No entanto, ele também serve para compreender como funciona o planejamento de cada uma dessas visitas: pensar em uma narrativa que seja sempre aberta à criatividade proposta pela criança. Assim, utilizando tules coloridos podemos plantar sementes da imaginação,

2 Com a orientação de nossa consultora pedagógica Santuza Bagno e o fortalecimento do grupo de estudos "Infância e Memória" no Educativo, buscamos diariamente o diálogo com a cultura da infância e suas linguagens (SARMENTO, 2004), construindo narrativas, realizando formações com professoras, produzindo materiais que incentivem o protagonismo infantil no MMGV e que também possam influenciar outros espaços de educação em nossa cidade. 
colhê-las no jardim do Memorial e plantar cada fala das crianças e seus desejos condizentes com os espaços. E, com os pequenos, plantamos café na fazenda, peixes nos caminhos (pois é claro que, com a imaginação, tudo pode ser plantado) e, como em um passe de mágica, acendemos uma fogueira nas minas rupestres e em torno dela questionamos: $\mathrm{O}$ que são esses desenhos nas paredes? E assim tratamos especificamente de dialogar com a expografia e incentivar a reflexão com base no que é "dado" no museu.

Ao tratarmos das visitas ditas espontâneas com crianças, como resultado do contato reflexivo com esse público, criamos o kit da infância. Este consiste em uma bolsa, oferecida às crianças com idade a partir de 3 anos, com os seguintes objetos: um binóculo, uma lupa, um espelho, uma lanterna e um mapa do espaço, feito com ilustrações e desafios para instigar o olhar da criança e incentivá-la a criar sua aventura com o adulto que a acompanha.

Os objetos listados representam algumas das ferramentas lúdicas utilizadas com diversos grupos e que, como no caso das crianças, mostram-se fundamentais por funcionarem como uma espécie de continuidade do corpo, além de saciarem a necessidade do toque, que consiste em uma limitação do espaço museal. Os objetos também funcionam como mediadores na visita e, ao utilizá-los, estamos estabelecendo recortes no espaço e buscando o encantamento do olhar, do qual Bagno sempre nos lembra: afinal, "limite e espaço são palavras-chave para o surgimento de novidade e surpresa nos campos existenciais infantis" (MACHADO, 2010, p. 96). E por que não também do adulto?

Os objetos, como recurso metodológico, estão presentes em todas as mediações, com grupos de diferentes faixas etárias, e intentam possibilitar a conexão sinestésica: cheiros de café, canela, cravo, mapa de Belo Horizonte, fotos do arquivo público da cidade, tangram para criação e vendas para tapar os olhos. Todos servem para colocar tanto o visitante como o educador em um estado de jogo e prontidão, criando encontros entre arte, patrimônio, gerações e Minas Gerais. Em vista disso, exploremos agora o segundo - e talvez o mais numeroso - público: a recepção dos grupos de ensino fundamental, médio e Educação de Jovens e Adultos (EJA) que realizam visitas agendadas.

Quando tratamos das visitas mediadas com esse público, compreendemos que o lazer, em sua forma lúdica, perpassa o entendimento da cidade e de seus equipamentos, como espaço de educação. E ainda confere 
a noção de que um passeio a um espaço cultural é uma forma de a escola abordar determinado conceito, possibilitando o contato com o patrimônio, utilizando recursos além do método tradicional de ensino, no qual o professor palestra e o aluno ouve e anota, assentado.

Nesse intuito, e como apontamos anteriormente, a equipe do Educativo do Memorial idealizou diversos recortes temáticos que, com base na expografia, foram além da proposta museográfica inicial. Embora cada um dos eixos se encontre norteado por um objetivo e salas específicos, a flexibilidade da sua execução varia segundo as demandas dos grupos que visitam o espaço. Temos então: "Literatura e Memória”; "Artes Visuais, Imagem e Memória”; "Africanidades e Memória”; "República e Memória”; "Cartografia e Memória”; e "Mineiridades". Visto que a análise de cada um deles ultrapassaria a extensão deste capítulo, tomemos somente alguns a título de exemplo, para entender como diversas abordagens lúdicas são utilizadas como ferramenta de mediação crítica e reflexiva.

Um dos espaços escolhidos para o percurso "Cartografia e Memória", que por sua vez "busca refletir sobre os espaços de ocupação do estado de Minas Gerais" (Plano EduCATIVo..., 2013, p. 14), é a sala de Caminhos e Descaminhos. Dividida em duas partes, é caracterizada pela exposição de mapas da época da Colônia, por um lado, e atuais, por outro. A música ambiente, imitando os sons da floresta, leva o visitante a imergir nesse cenário de aventura, em uma mistura de audácia e temor. Uma das abordagens propostas pelos educadores leva os visitantes, de olhos vendados, a escutarem relatos de viajantes naturalistas dos séculos XVIII e XIX ricos em descrições (CARVAlHo, 2011), receberem caixas com diversas texturas do mato (folhas, penas, sementes etc.), no intuito de imaginarem a composição daquela natureza e refletirem, por exemplo, sobre como teria sido adentrar a mata virgem sem a tecnologia da atualidade. Quais seriam os sentimentos envolvidos nessa aventura? Seriam os mesmos para os bandeirantes e para um grupo de escravos? Finalizado esse momento, os visitantes tiram as vendas e se deparam com pranchas de aquarelas e pinturas da época que estampam a flora e a fauna. Dessa forma, aprofundamos a discussão do que significou o processo de povoamento da capitania de Minas Gerais, assim como outros tópicos, como a ecologia: Por que é mais difícil hoje em dia achar paisagens com essas características? O que cada um de nós faz em prol da natureza?

Um dos percursos solicitados pelos grupos agendados é o de "República e Memória", que busca "problematizar a implantação da 
República no Brasil, identificando os conceitos, símbolos e espaços públicos que marcaram o ideal republicano em Minas Gerais" (PLANO EDUCATIVo..., 2013, p. 13). Dele faz parte uma das salas pelas quais, talvez, o museu é mais conhecido: a do Panteão da Política Mineira, que relata o planejamento da Inconfidência Mineira por meio de nove quadros com atores que representam personagens do levante. De forma lúdica, o público visitante fica imerso em uma discussão que envolve questões políticas, econômicas e culturais da época da Colônia. Porém, a reflexão não se desenvolve apenas nos trinta minutos de duração da visita à sala: perguntas prévias são realizadas pelos educadores para instigar o grupo na fruição do momento e em diálogos posteriores. Exploremos uma delas: uma vez que os inconfidentes discutem a criação do estandarte da futura república mineira, os educadores propõem, mediante o uso do tangram, a criação de uma bandeira. Assim, discute-se sobre os valores representados pelas formas e cores escolhidas: É uma república que abraça as diversidades? Quem são representados? O que significa um povo livre?

Outro espaço que integra esse percurso é o das Vilas Mineiras, a recriação de um assentamento colonial em forma de maquete, cuja iluminação recria os diferentes momentos do dia. Uma das possíveis abordagens da sala, com o objetivo de ampliar o assombro do visitante, é levar o grupo de olhos vendados. Com a proposta de fazer "uma viagem no tempo", o público fica de costas para a maquete e o educador oferece a cada membro um espelhinho, por meio do qual observará a sala. A sensação é a de ter sido deslocado no tempo e no espaço. Após um tempo de contemplação, convida-se o grupo a debater questões relativas à sala: Como teria sido viver em uma vila como esta? Qual era o conceito do urbano naquela época? Conseguimos imaginar uma vida sem saneamento básico, eletricidade e esgoto? E hoje em dia isso é usufruto de todos? O que acontecia no cotidiano dos séculos XVII e XVIII? Que sentido de privacidade era o da época? Que tipo de alimento fazia parte das refeições? E sobre o estilo arquitetônico, há semelhança com o que encontramos em Belo Horizonte hoje? O que acontece com os personagens que percorriam estas vielas? Quem construía as igrejas podia frequentá-las? Será que o cristianismo era o único tipo de crença na época? E, hoje em dia, o que acontece com os descendentes das religiões de matriz africana?

$\mathrm{O}$ último percurso que aqui indagaremos é o denominado "Mineiridades". Sob o termo preserva-se uma diversidade aguardando ser descoberta. Entre as salas escolhidas para esse recorte encontra-se a 
Fazenda Mineira, repleta de objetos do cotidiano rural, convidando a uma viagem no tempo e no espaço. Junto ao violão e às calmas cores, o visitante pode esquecer que está, na verdade, em plena cidade. A sala, por si só, já é um convite à dispersão e contemplação - ora, quando mediada por um educador, vai além disso. Uma das propostas está baseada no sentido olfativo: diversas especiarias são distribuídas em pequenos sachês aos visitantes. Que memórias acordam esses cheiros? Falar de fazenda é falar da roça, de sossego, de culinária típica, mas também de árduo trabalho. Mas qual das duas experiências a sala evoca? Será que todo mineiro, como diz Waldemar de Oliveira Barbosa, "seja qual for a função que exerça, é fazendeiro em potencial” (BARBosa apud DANGELo, 2011, p. 147)? ${ }^{3}$

Os relatos e as questões apresentadas, como fruto das mediações com o público agendado, revelam o longo caminho que percorremos e estamos percorrendo - no intuito de fortalecer uma metodologia da escuta, uma metodologia do encontro de saberes do educador, estudantes e professores. Todavia, a visita do público espontâneo, sem agendamento e sem mediação, apresenta outras especificidades. Nesses casos, temos a possibilidade de instigá-lo por meio das Ações Educativas, que consistem em atividades, jogos, instalações, imersões, que requerem desse público um tempo de pausa, de reflexão conduzida no passeio pelo museu. Nessas ações, somos desafiados a criar diversão e conteúdo que requeiram pouco tempo para ser concluídos. Talvez, por isso, as ações educativas representem o maior ponto de tensão entre a experiência museal e as concepções de lazer trazidas.

Ao longo desses anos, pudemos diagnosticar as preferências desse visitante, que em sua maioria condizem com o "desembaraçar das obrigações", e ao mesmo tempo pudemos inserir pouco a pouco conhecimentos de forma divertida, afinal (a)preender pode ser, sim, muito prazeroso!

3 Mas o que viria a ser a cultura de Minas? O que estaria guardado em um memorial de Minas Gerais? Esse é um assunto que envolve várias tensões, sobre o qual os educadores estão preparando um material para publicação, no intuito de repensar o que é ser mineiro com base na historiografia contemporânea. Contudo, refletindo sobre as mineiridades com relação à expografia do MMGV, é necessário lembrar o que citamos no tópico anterior, isto é, o exercício de problematizar "os traços ideológicos passados dos museus" (Menezes apud Juliño, 2006, p. 101). E talvez esse seja o ponto comum que conecta as práticas realizadas - o olhar crítico do educador ao preparar a visita, de forma que possa fazer surgirem diálogos silenciados na expografia. Mas como fazer esses diálogos surgirem com o invisível, com um público que não está acompanhado de um educador? 
Alternamos entre práticas que requerem a condução mais próxima do educador em relação ao público e outras ações lúdicas nas quais o visitante pode jogar/fruir/refletir por si mesmo, no seu tempo. Ações simples como: montar sua própria poesia em um quadro magnético, como no "Arte Palavra"; marcar sua relação com uma cidade mineira em um grande mapa, com um post-it, na "Geografia da Memória”; vestir figurinos que remetem aos personagens de Minas presentes no MMGV, como na "Traje a Rigor". Todas elas têm se mostrado bastante efetivas aos nossos objetivos. Nessas e em outras ações buscamos alcançar o processo duplo apontado por Marcellino (1998), no qual a ação se torna veículo potente de educação; educação no sentido amplo, vinculado ao processo de problematização e desnaturalização do cotidiano com cuidado pedagógico e estético.

\section{Conclusão}

$\mathrm{Na}$ atualidade, enfrentamos um problema em relação ao lazer, uma vez que nessa lógica capitalista de alienação permanente, na qual a liberdade se encontra cerceada e o que movimenta tudo é a produção, o ser "produtivo" foca-se na ânsia de lucro sem fim e a fruição traz um sentimento de culpabilidade. Por esse motivo, Marcuse propõe novos contornos ao termo, ao juntá-lo com o conceito de jogo, já que, por ser "improdutivo, é inútil precisamente porque anula as características repressivas e exploradoras do trabalho e do lazer" (Marcuse apud Marcellino; Nascimento, 2012, p. 31) e, assim, foge da dinâmica alienadora do sistema.

À vista disso, e com pequenos passos, buscamos tensionar a lógica museal para que o MMGV se torne um espaço que permita o aproveitamento de um tempo, contrário a essa dinâmica que aliena o sujeito. Uma vez que o museu é escolhido como possibilidade de lazer e divertimento, procuramos, então, que a visita seja uma experiência significativa e reflexiva e, assim, fortaleça esse espaço cultural para, de fato, transformar-se em local de mediação de saberes entre os educadores e os atores presentes, por meio das mediações e das ações educativas.

Nesse sentido, se as camadas subjugadas, segundo Marcuse, não possuem condições econômicas para o acesso às mercadorias destinadas ao prazer e, portanto, acabam sendo controladas pela sociedade de forma repressiva (MARCELlino; NASCimento, 2012 p. 33), o capital cultural não vai além de uma camada muito restrita da população, cerceando sua 
socialização. Noutros termos, como argumenta Bourdieu (2007, p. 299), apesar de os bens culturais serem, na teoria, estendidos à sociedade em sua totalidade, apenas aquela porção que possui os meios para sua decodificação é que realmente os consome.

Todavia, o fato de esse espaço museal ser gratuito possibilita a maior abrangência de público, no intuito, como assinalado anteriormente, de democratizar o acesso à informação a outras camadas da sociedade. Talvez a localização do MMGV seja um obstáculo nesse sentido, já que se trata "de um lugar monumental, cuja simbologia de espaço nobre esteve primeiramente ligada ao poder político e, agora, às atividades culturais" (Andrade; Veloso, 2014, p. 231). Porém, percebe-se que a chamada "Aula Passeio", projeto das escolas integradas da Prefeitura de Belo Horizonte e cuja maior porcentagem de alunos pertence à periferia da cidade, é um pequeno passo para atingir esse público que, enquanto "passeia" pelo museu, interage com discursos, imagens e objetos e é incentivado a refletir sobre sua experiência em conexão com a expografia, em um espaço de educação não formal.

Por conseguinte, ao propor o museu como local lúdico, no sentido do lugar da não produção capitalista, a ânsia se inverte: é a ânsia do conhecimento, do descobrimento, da curiosidade, a que marca o tempo. Nada material está sendo produzido, mas aquilo que é dialogado, transmitido e vivenciado no museu pode resultar em uma experiência transformadora para o indivíduo, com a reflexão sobre os assuntos mais variados, isto é: a herança africana no Brasil; o papel da mulher na cultura; o mosaico cultural que é Minas Gerais; a diversidade de religiões que atravessa o país; entre tantos outros. Uma contraproposta à alienação oferecida - e almejada - pelo sistema. Logo, o lazer no MMGV, hoje, é compreendido como um encontro de diferentes sujeitos e culturas, na tentativa de dar voz às histórias silenciadas ao longo do tempo e, paralelamente, integrar divertimento, ludicidade e conhecimento de si e do mundo.

\section{Referências}

Almeida, M. A. B.; Gutierrez, G. L.; Marques, R. O lazer como objeto das ciências humanas. Revista Licere, Belo Horizonte, v. 11, n. 3, p. 1-15, dez. 2008.

Andrade, L. T.; Veloso, C. S. Intervenções urbanas mediadas pela cultura e os usos dos espaços públicos. Ciências Sociais Unisinos, São Leopoldo, v. 50, n. 3, p. 225-233, set./dez. 2014. 
Bourdieu, P. A economia das trocas simbólicas. São Paulo: Perspectiva, 2007. Carvalho, F. A. A memória toponímica da Estrada Real e os escritos dos viajantes naturalistas dos séculos XVIII e XIX. In: Simpósio BrasiLEIRO DE Cartografia Histórica, 1., 2011, Paraty. Anais... Paraty: UFMG, 10-13 maio 2011. Passado presente nos velhos mapas: conhecimento e poder. Disponível em: <https://www.ufmg.br/rededemuseus/crch/simposio/ CARVALHO_FRANCISCO_DE_ASSIS.pdf >. Acesso em: 8 maio 2018.

Chagas, M. S. No museu com a turma do Charlie Brown. Cadernos de Sociomuseologia, Lisboa, v. 2, n. 2, p. 49-65, May 2009. Disponível em: $<$ http://revistas.ulusofona.pt/index.php/cadernosociomuseologia/article/ view/535>. Acesso em: 6 maio 2018.

Considera, A. F. Direito à memória e museus. Museologia $e$ Interdisciplinaridade, Brasília, v. 4, n. 8, p. 147-157, dez. 2015.

Dangelo, A. G. D. Fazenda mineira: séculos xviII-XIX. In: Starling, H. M. M. et al. Minas Gerais. Belo Horizonte: Editora UFMG, 2011. p. 142-149.

Dumazedier, J. Lazer e cultura popular. 3. ed. São Paulo: Perspectiva, 2001. Gonçalves Possas, H. C. Classificar e ordenar: os gabinetes de curiosidades e a história natural. In: Gonçalves Figueiredo, B.; Gonçalves Vidal, D. (Org.). Museus: dos gabinetes de curiosidades à museologia moderna. 2. ed. Belo Horizonte: Fino Traço, 2013. p. 159-170.

Julião, L. Pesquisa histórica no museu. In: Caderno de Diretrizes Museológicas. Belo Horizonte: Secretaria de Estado da Cultura; Superintendência de Museus, 2006. p. 95-107. Disponível em: $<$ http://www. cultura.mg.gov.br/files/Caderno_Diretrizes_I\%20Completo.pdf $>$. Acesso em: 2 mar. 2019.

Machado, M. M. Merleau-Ponty \& educação. Belo Horizonte: Editora Autêntica, 2010.

Marandino, M. Educação, comunicação e museus. In: Marandino, M. (Org.). Educação em museus: a mediação em foco. São Paulo: Geenf; FeusP, 2008. p. 7-17.

Marcellino, N. C. Lazer: concepções e significados. Revista Licere, Belo Horizonte, v. 1, n. 1, p. 37-43, 1998.

Marcellino, N. C.; Nascimento, R. M. Possíveis contribuições de Hebert Marcuse aos estudos sobre o lazer. Revista Corpoconsciência, Santo André, v. 16, n. 2, p. 27-35, jul./dez. 2012.

Meneses, U. T. B. A exposição museológica e o conhecimento histórico. In: Figueiredo, B. G.; Vidal, D. G. (Org.). Museus dos gabinetes de curiosidades à museologia moderna. Belo Horizonte: Fino Traço, 2013. p. 15-88. 
Plano Educativo Memorial Minas Gerais Vale. Brasília: MEC; Fundação Vale, 2013. Disponível em: <http://memorialvale.com.br/wpcontent/uploads/2017/07/plano-educativo.pdf >. Acesso em: 1 abril 2018.

SARmento, M. J. As culturas da infância nas encruzilhadas da segunda modernidade. In: Sarmento, M. J.; Cerisara, A. B. Crianças e miúdos: perspectivas sociopedagógicas da infância e educação. Porto: Asa, 2004. p. 9-34.

Unesco - Organização das Nações Unidas para a Educação, a Ciência e a Cultura. Recomendação referente à proteção e promoção dos museus e coleções, sua diversidade e seu papel na sociedade. Paris: Conferência Geral, 20 nov. 2015. Disponível em: <unesdoc.unesco.org/ark:/48223/pf0000247152>. Acesso em: 20 mar. 2019. 


\section{CAPÍTULO 15}

\section{O TEATRO E O CIRCO NA FORMAÇÃO DO ANIMADOR SOCIOCULTURAL}

Maria Clara Lemos dos Santos

Rogério Lopes da Silva Paulino

Este capítulo consiste no apontamento e na discussão das possíveis contribuições do teatro e do circo para o campo de estudos do lazer e, mais especificamente, no processo de formação profissional do animador sociocultural. Essa abordagem se dará com base nos relatos de experiências de práticas pedagógicas e de projetos desenvolvidos no curso técnico em teatro do Teatro Universitário da Universidade Federal de Minas Gerais (UFMG), que embasaram a criação do curso técnico em lazer proposto por essa escola e em tramitação na UFMG no ano de 2018.

O Teatro Universitário da UFMG, umas das mais antigas escolas de teatro do país, após setenta anos dedicados à formação de atores, propõe a abertura de um novo curso em consonância com o fluxo de expansão da rede federal de ensino técnico ampliando, de acordo com o Catálogo Nacional de Cursos Técnicos da Secretaria de Educação Profissional e Tecnológica do Ministério da Educação (SETEc/MEC), seu eixo de atuação: design e produção cultural (teatro) para lazer, turismo e hospitalidade (lazer). No ano de 2017, apresentou para a comunidade universitária a proposta de criação do curso técnico em lazer, ainda em tramitação nas instâncias da UFMG. A constatação de que muitos elementos próprios do campo de estudos do lazer já apareciam de maneira frequente nessa escola, sejam em suas práticas pedagógicas, em programas de estágios, nos projetos de pesquisa e extensão ou nos frequentes relatos de engajamento de alunos e ex-alunos com atividades profissionais ligadas 
ao universo do lazer, foram primordiais para que o Teatro Universitário propusesse a criação do curso técnico em lazer ${ }^{1}$.

Autores como Isayama (2005) e Silva (2017) argumentam, no entanto, que a formação no campo do lazer está dividida entre uma abordagem técnica mais instrumental e outra ligada à especialização, em que a fundamentação crítica está mais presente. É justamente aí que acreditamos que o teatro tem a contribuir ao oferecer princípios e procedimentos nos quais essas duas dimensões estão frequentemente articuladas. Isso se deve ao fato de que o campo das artes cênicas possui debate similar, focado na articulação entre prática e teoria no tangente à produção de conhecimento acadêmico - o que gerou uma série de estudos abordando essa temática propostos por autores como Cabral (2003), Féral (2001) e Isaacsson (1999). Nossa intenção é auxiliar a encontrar alternativas para o campo de estudos do lazer em que, assim como propõe Bião (1999) para o teatro, consigamos que o fazer e o refletir não sejam inconciliáveis, mas apenas não ocorram simultaneamente o tempo todo. Para esse autor, a "reflexão crítica e criativa em forma de pesquisa deve acontecer como antecedente e consequência da criação artística pesquisada. Criação e crítica em termos pragmáticos, só existem alternando-se no tempo" (BIÃo, 1999, p. 257).

Neste capítulo, além das contribuições do teatro para o campo do lazer, daremos especial destaque para as contribuições advindas do cir$\mathrm{CO}^{2}$. Esse destaque se faz necessário por ser a presença do circo na matriz curricular do curso técnico em teatro um dos elementos que o particulariza entre outros cursos de formação de atores, sendo um conteúdo

1 De acordo com o projeto político pedagógico do curso técnico em lazer proposto pelo Teatro Universitário da UFMG, o profissional egresso deverá ser capaz de conduzir atividades ligadas ao lazer da infância à fase adulta, desenvolver atividades socioeducativas em projetos de educação integral, em colônias de férias, projetos de inserção sociocultural de crianças e adolescentes. Organizar e executar atividades recreativas em instituições públicas e privadas, como hotéis, clubes, museus, centros culturais, teatros, ruas de lazer, entre outras. Ser capaz de coordenar e executar campanhas de mobilização sociocultural, como educação para o trânsito, boas práticas alimentares, coleta seletiva de lixo etc. O egresso deverá ser capaz de trabalhar em equipe e realizar dinâmicas de grupo utilizando recursos artísticos e culturais diversos (PPP, 2017, p. 16).

2 O reconhecimento do circo como área de conhecimento no Teatro Universitário pode ser constatado pela inserção das disciplinas técnicas circenses I e II em sua matriz curricular a partir de 1992. 
que dialogará diretamente com o universo do lazer. Assim, passaremos a descrever como esses elementos foram abordados em projetos e práticas pedagógicas do Teatro Universitário nas últimas décadas, acreditando que, ao escolhermos essa abordagem com viés histórico, contribuiremos para recuperar e registrar práticas e projetos relevantes desenvolvidos na UFMG: seja o pioneirismo do Teatro Universitário como escola técnica de teatro no Brasil, ou a manutenção de conhecimentos tradicionais, como os do circo, na matriz curricular de seus cursos.

\section{Autonomia criativa e trabalho coletivo}

Logo no início de sua formação, os alunos entram em contato com a criação de esquetes teatrais (peças de curta duração), aprendendo a construir tanto a dramaturgia como as maneiras de atuá-las. Esse conteúdo os leva a explorar o exercício da autonomia criativa, uma vez que são eles próprios quem escrevem os textos de maneira coletiva, sob a orientação do professor. As técnicas utilizadas para a encenação dessas peças curtas são oriundas, principalmente, de elementos da cultura popular brasileira, como os mamulengos - uma das principais formas de teatro de boneco do Nordeste, assim como os cordéis e recursos do próprio circo - melodrama, acrobacias e equipamentos como as pernas de pau. O diálogo com a cultura popular, que por natureza diversificada se renova constantemente, faz com que os alunos sejam incentivados a trazer elementos próprios do seu cotidiano, dialogando com estéticas contemporâneas como o funk, por exemplo. Desse modo, os alunos não só reconhecem suas origens no processo criativo, quanto investigam elementos de sua constituição identitária, favorecendo o seu protagonismo.

A metodologia é simples, mas eficiente: os alunos partem de argumentos iniciais, como um fato histórico ou algo marcante ocorrido recentemente; constroem uma pequena estrutura inicial do texto e passam a experimentá-la via improvisações cênicas coletivas. Esse processo favorece o melhor desenvolvimento do tema e do sentido do texto, que, ao mesmo tempo em que é esclarecido, passa por transformações e desdobramentos até que se alcance a síntese do tema abordado. Outra possibilidade é a de recorrer diretamente à seleção de cordéis ou textos dramáticos já existentes, utilizando-os como mote inicial para a improvisação das cenas. A métrica do texto é respeitada, passando a dialogar com a corporalidade desenvolvida pelos alunos durante a criação cênica. 
A autonomia criativa dos alunos é incentivada quando, no trabalho coletivo, eles precisam tomar decisões sobre quais caminhos seguir na criação. Procedimentos como esses guardam relação com os modos de criação coletiva do grupo colombiano La Candelaria, descritos pelo diretor Santiago Garcia (1988, p. 37), segundo o qual:

o texto é o último elemento a se concretizar definitivamente ou pode ser que nunca chegue a ponto de se definir totalmente. [...] Poderíamos afirmar que este caráter relativamente aberto do texto é uma das características de um trabalho de criação coletiva. Apesar de que nos últimos trabalhos escrevemos os textos dos diálogos das obras, durante as representações e no contato com o público esse texto vai mudando.

A possibilidade de revisar as criações a todo momento (em virtude do contato com o público) favorece aos alunos o desenvolvimento do senso crítico e a prontidão para interagir e avaliar os diversos contextos em que venham a atuar. Por isso, essa metodologia tem um forte efeito multiplicador, uma vez que capacita os alunos a continuarem com o trabalho de diversas formas, mesmo depois de finalizada a disciplina. É comum os alunos continuarem a apresentar essas cenas por conta própria em feiras, mostras, exposições e demais eventos turísticos da cidade, ou contratados por empresas e/ou escolas que porventura tenham algum interesse pelos temas abordados na disciplina.

\section{A pesquisa de campo}

Outro aspecto imprescindível na formação teatral e que pode ser bastante útil para a formação do profissional do lazer é o fato de que os alunos são incentivados a entrar em contato com a realidade pesquisada de diversas maneiras, sendo o trabalho de campo uma das mais utilizadas. Com isso, os alunos são levados a compreender de maneira ampla a realidade em que estão inseridos ou em que atuarão. $\mathrm{O}$ incentivo à realização do trabalho de campo pode favorecer a construção de um pensamento crítico sobre a realidade social, fundamental para a formação do técnico em lazer, como argumenta Silva (2017). Segundo essa autora, "é preciso investir em processos de formação nos quais os profissionais sejam desafiados à construção de conhecimentos e, com isso, ressignificar a atuação" (SILVA, 2017, p. 44). A prática do trabalho de campo nos parece ir nessa direção ao potencializar e enriquecer a formação do aluno, que, 
ao entrar em contato com contextos socioculturais diferentes do seu, é provocado a desenvolver habilidades para interagir diretamente com os problemas reais de cada novo contexto.

Foi o que aconteceu, por exemplo, com os alunos que realizaram pesquisa de campo no Parque Municipal Américo Renné Giannetti, em Belo Horizonte, Minas Gerais. Durante todo o semestre, os alunos realizaram uma série de visitas ao parque para compreender, in loco, o seu funcionamento e o perfil de seus frequentadores. No decorrer da pesquisa, eles se depararam com questões como o êxodo rural, o trabalho doméstico, a convivência de diferentes classes sociais no espaço urbano e com as questões impostas pela própria administração pública do parque. Essas questões foram debatidas em sala de aula e, depois, utilizadas como base para construção das esquetes que posteriormente seriam apresentadas em espaços públicos da cidade. Em outra disciplina, os alunos foram levados a realizar visitas a instituições de longa permanência e a conviver com os idosos no decorrer do semestre, despertando a sensibilidade e a consciência social e política para as questões relacionadas à terceira idade (o que também, serviria de base para as esquetes).

É importante ressaltar que, mesmo nas esquetes de caráter cômico, os alunos foram incentivados a não perder de vista o compromisso com a ética e com as questões sociais. Dessa maneira, eles não só tiveram um processo de apreensão daquela realidade in loco, como puderam levar o conhecimento adquirido nessa experiência para o público em forma de esquetes, reelaborando-o de maneira lúdica, oferecendo ao público um tipo de entretenimento e lazer nada "pasteurizado". Nesse sentido, poderíamos fazer um paralelo com o que Silva (2017, p. 41) aponta:

Para além da visão utilitarista, o entendimento do lazer numa perspectiva crítica e não conformista, em termos de valores e funções, possibilita a compreensão da realidade em níveis mais complexos, enriquecendo o espírito crítico. Tal compreensão dar-se-á mais rapidamente pela ação educativa para o lazer associada à sua vivência que pela restrita participação nas atividades, ou seja, à educação pelo lazer.

Acreditamos que incentivar a compreensão mais elaborada dos contextos em que os alunos estão atuando (proporcionada pela pesquisa de campo) pode ser uma estratégia importante na formação de um técnico em lazer, favorecendo o desenvolvimento de uma percepção sensível e a consequente proposição de ações criativas para intervir naquele contexto. 
A maneira como o trabalho de campo é realizado no teatro tem papel fundamental nesse processo, principalmente por apresentar características distintas da maneira como, muitas vezes, é feito na antropologia uma das áreas de conhecimento na qual essa metodologia é central. Essas diferenças levaram autores como Marcus (2004) a apontar como os atores e diretores teatrais teriam a contribuir com as ciências humanas na própria maneira de repensar a atuação dos profissionais no trabalho de campo. Segundo esse autor, para os atores, o que importa é o desenvolvimento de uma sensibilidade originada de uma "cumplicidade entre o observador e o observado e pela pesquisa em campos multilocalizados" (MARCus, 2004, p.133). Foi assim que os alunos, durante o semestre em que visitaram diferentes instituições de longa permanência, desenvolveram laços de afeto com os idosos, que por sua vez transformaram a maneira como eles se relacionavam com esse universo - até então desconhecido e cheio de conceitos prévios. Nesse sentido, essa atitude de proximidade substituiria o distanciamento e a limitação espacial próprios da pesquisa de campo clássica, que visaria a uma pretensa objetividade científica.

\section{Revirando a técnica}

Dizendo especificamente da área de conhecimento do circo, as técnicas de malabares, perna de pau, acrobacias e equilibrismo são algumas das que podem ser ensinadas e apropriadas pelos alunos em formação em teatro. Em uma perspectiva de instrumentalização, essas técnicas capacitam os alunos a trabalharem como monitores de colônia de férias, recreacionistas, animadores de festas infantis e de confraternização de empresas. Contudo, vale apontar que o circo não tem apenas essa abordagem instrumentalizadora, embora seja essa dimensão a que mais se destaca.

Se em um simples ato de virar de cabeça para baixo inverte-se literalmente um ponto de vista, propor uma vivência circense possível a qualquer pessoa que estiver disposta a se movimentar é mais que desafiador, é uma diversão! As pessoas que se aproximam de uma prática que exige segurança e equipamentos específicos para sua realização, por vezes, sentem-se temerosas. E, da mesma forma, quem as ensina pode considerar impossível trabalhar os princípios das técnicas circenses sem todo o aparato material necessário. Longe de considerarmos que a segurança não é primordial, apresentamos aqui as possibilidades de construí-la por meio das relações de conhecimento de si e do outro. Assim, se julgarmos que 
o circo é uma área de conhecimento de difícil acesso pela necessidade de equipamentos específicos, que tal propormos práticas acessíveis a todos?

Possíveis de serem realizadas em colônias de férias, parques, clubes, escolas, praças e nos mais variados ambientes, as atividades que envolvem o equilíbrio em latas, em garrafas plásticas cheias de água, ou em tamancas (pernas de pau construídas de madeiras com um pequeno suporte para os pés, que são puxadas pelos braços, em uma coordenação entre braços e pernas, diferentemente das pernas de pau que são "vestidas", amarradas nas pernas como se fossem uma extensão do próprio corpo) podem desenvolver os mesmos princípios corporais do equilibrismo circense. Da mesma forma, podemos trazer àquela pessoa que tem medo de "quebrar o pescoço" ao virar uma cambalhota a coragem de fazê-la sem colchões, utilizando o corpo do colega como o possibilitador dessa vivência. Ao acreditarmos que o corpo do outro nos traz possibilidades de suporte e sustentação e vice-versa, o princípio da aprendizagem circense (e corporal) está estabelecido.

Se no circo a técnica prevalece, na animação sociocultural a técnica é mais um elemento de autoconhecimento, importando aqui que o indivíduo reconheça seu corpo como portador de medos, coragens e incertezas, aceitando as diferenças e possibilidades de atuações pelo prazer de se conhecer e se reconhecer. Não que esses sentimentos, essas descobertas, não serão vivenciadas pelo circense ou pelo ator, pois afinal de contas todos somos os mesmos seres humanos anteriormente às ocupações como atores ou circenses. Mas, quando a atividade fim é a virtuose técnica, há que se ultrapassar ou transformar essas experiências em busca do resultado, há que se dedicar mais tempo de trabalho, pesquisa e vivência para se lapidar os movimentos em prol de uma estética. No caso da animação sociocultural, a vivência do momento e o prazer vêm em primeiro plano. A técnica vem posteriormente, como propiciadora dessa vivência.

Tomemos, por exemplo, a perna de pau: no circo, o que se espera é que ela esteja tão integrada ao corpo do circense que o público nem perceba que aquilo não faz parte de seu corpo, pois o circense se desafiará a correr, pular, saltar, fazer piruetas com um tamanho que não é o seu, acrescido de um peso que não visualizamos como espectadores. No teatro, pode-se trazer a perna de pau como a construção do corpo de um gigante, de uma personagem que não necessariamente trará o virtuosismo e os desafios gravitacionais para a cena, como no circo. Já na vivência do lazer, o desafiar-se a subir e equilibrar-se sobre objetos e plataformas ou pisos instáveis traz para o indivíduo a proximidade com seu corpo em 
movimento. Se isso lhe facilitará ou despertará seu interesse por ir mais adiante, será magnífico! Mas, se não, o simples fato de se permitir já lhe abrirá para o campo das percepções, e perceber-se em relações (espaciais, temporais, corporais) é a tônica primeira.

Do mesmo modo acontece com as demais técnicas circenses: para se efetuar um salto mortal, em que o corpo desafia a gravidade e executa uma ou mais voltas no ar, será melhor que ele seja feito com segurança, em um solo que possa lhe acolher ao pousar no chão. Se o rolamento inicial, ou a cambotinha, cambalhota e outros nomes similares, tem o objetivo final de se chegar ao extremo do desafio no ar, será necessário fazer, refazer, limpar, polir esse movimento até que se perceba em qual momento o corpo se abrirá no ar, como será a posição dos braços, da cabeça, se o impulso se dará a partir do chão, de um trampolim, de uma cama elástica, das mãos de parceiros. Para o ator, essa cambalhota poderá ser metafórica, ajudando a traduzir uma passagem do tempo, um deslocamento no espaço. Já para aquele que a executa pela primeira vez, em uma brincadeira, em uma experiência corporal, poderá ser ensinado tomando como premissa a construção da relação de confiança com o outro, podendo-se até suprimir os colchões de segurança, mas nunca a segurança!

Ao propormos uma maior abrangência da docência para além do currículo ofertado aos atores em formação no Teatro Universitário, amplia-se ainda mais a diversidade dos corpos que ali chegam: corpos/ indivíduos de diferentes áreas de conhecimento, com muita, pouca ou quase nenhuma experiência circense, mas todos carregados de identidade própria, com desejos distintos, ávidos pelo movimento. Os alunos da disciplina "formação transversal em culturas em movimento e processos criativos", por exemplo, não têm como atividade fim a cena ou o espetáculo com exibição para o público ao vivo. Ali começamos com atividades de reconhecimento do espaço, de consciência desse corpo naquele espaço e as percepções desse corpo/espaço com os outros corpos ali presentes. Com exercícios que conduzem ao contato físico entre esses corpos, em uma proposta de perceber-se pelo outro e com o outro, deslocando seu próprio peso em contato com outros corpos, sustentando-os, empurrando-os, percebendo o peso e o contrapeso, vão adquirindo-se novos "vocabulários" corporais, construindo confiança, apoios, disponibilidades, noções de cuidados, segurança consigo e com o grupo. Estabelecidas e construídas essas relações, passa-se ao reconhecimento de possíveis apoios: um colega coloca-se apoiado sobre os joelhos e mãos, na posição de quadrúpede. $\mathrm{O}$ outro coloca uma de suas mãos entre as escápulas do 
que está com os apoios no chão e outra sobre a região sacral e desloca seu próprio peso sobre o corpo do colega. Este, por sua vez, sente seus quatro apoios no chão e oferece resistência a esse novo peso, para sustentá-lo sem se despencar pelo chão. Daí, gradativamente, ele vai conhecendo-se e reconhecendo-se no e pelo outro. Agora o que estava de pé e que experimentou a resistência do outro corpo que o sustentava vai colocar sua barriga nas costas do parceiro, ficando em uma posição de equilíbrio, sem que as mãos ou os pés toquem o chão, como se fosse um avião. Em um segundo momento, esse corpo suspenso vai buscar o contato das mãos no chão e se arrastar até ele, saindo das costas do colega e se rastejando como um jacaré. O desenvolvimento desse exercício pode chegar até a cambalhota, utilizando o próprio corpo do colega para realizá-la. Assim, a compreensão e a experimentação da rotação do corpo e da mudança de apoios são vivenciadas de forma segura, contando com o apoio fundamental do outro, tornando possível a realização de algo difícil à primeira vista.

Isso também pode acontecer ao se propor o equilíbrio sobre latas de diversos tamanhos, em que se pisa uma a uma, alternando-se os pés, como que percorrendo uma trilha instável e sempre com o apoio do colega. Essa trilha pode estar previamente construída ou ir construindo-se a cada novo passo do equilibrista. Pode-se também fazer um furo de cada lado da lata para passar um barbante que chegue às mãos do equilibrista, construindo-se assim um brinquedo chamado pé de lata. $\mathrm{O}$ deslocamento com os pés de lata são de coordenação similares à da tamanca e se faz puxando os pés pelo barbante a cada passo. Outra possibilidade de equilíbrio pode ser vivenciada com uma garrafa plástica de dois litros, cheia d'água e bem tampada. Um colega, com o apoio do outro, sobe com os pés (descalços ou calçados) sobre a extensão da garrafa, perpendicularmente. O simples fato de se colocar sobre um objeto arredondado lhe fará o movimento de deslocamento. Restará, então, conseguir desafiar o equilíbrio do corpo em movimento, descobrindo a relação do eixo corporal com a velocidade do deslocamento e, obviamente, auxiliado pelo apoio do corpo do colega (que se pode colocar à frente daquele que se desloca, dando-lhe as mãos e acompanhando-lhe o deslocamento). $\mathrm{Na}$ medida em que esse corpo vai adaptando-se e criando recursos para se equilibrar nessa nova situação, o companheiro poderá lhe propor novos desafios, como lhe oferecer menos apoios. A partir daí, construídas as relações com o espaço, os corpos, o objeto, novos desafios podem surgir: deslocar-se para trás, sobre a garrafa, ou mesmo o maior desafio: permanecer em equilíbrio estático! 
Nesse simples brincar, estar-se-á desenvolvendo princípios circenses de equilíbrio que poderão ser levados para o rola-rola ${ }^{3}$, para a perna de pau, para a corda bamba ou o arame esticado, via transferência de aprendizagem. A transferência de aprendizagem é um termo utilizado por Schmidt e Wrisberg (2001), em que as experiências motoras anteriores podem influenciar ou até mesmo determinar a aprendizagem do indivíduo em uma nova tarefa, podendo "refletir tanto na aprendizagem técnica do movimento quanto na sua utilização para a composição de um espetáculo teatral ou de um número circense" (SANTOS, 2006, p. 37).

Apoiados na transferência de aprendizagem, cria-se a possibilidade de que essas técnicas se tornem acessíveis a todos: tanto para a pessoa em busca de entretenimento e vivências corporais quanto para aquele que queira instrumentalizar-se para ensiná-las. Assim, essas descrições vêm ilustrar as possibilidades de se trabalhar elementos fundamentais da acrobacia e do equilibrismo em uma situação de lazer, sem que os aparelhos circenses sejam pré-requisitos para a realização do movimento.

A consciência do corpo vivenciada pela prática circense, o enfoque nos princípios do movimento e não na virtuose técnica e o incentivo à autonomia criativa, ao trabalho coletivo e à pesquisa de campo são fatores que nos pareceram trazer contribuições significativas para a formação técnica em lazer, principalmente por auxiliar o aluno a ter uma compreensão mais global de sua atuação e a desenvolver pontos de vistas críticos sobre o seu fazer.

\section{Campos de atuação}

Se observarmos as ocupações de boa parte dos alunos e profissionais formados em teatro, verificaremos que muitos exercem atividades relacionadas às práticas desse campo do lazer por meio do ferramental oferecido e exercitado durante o percurso realizado nessa escola. É muito

3 O rola-rola é um aparelho circense de equilíbrio, composto de um cilindro e uma plataforma. O cilindro fica em contato com o solo e é o eixo central no qual a plataforma será colocada. O desafio é manter-se equilibrado sobre a plataforma, sem que ela tombe para um lado ou para outro. Em situações de maior virtuosismo, o circense faz esse equilíbrio em uma superfície longe do solo, ajoelhando-se sobre a plataforma, equilibrando objetos ou mesmo realizando números de portagens (sustentação de corpos, similar a um pas de deux da dança). 
comum os alunos passarem a trabalhar como estagiários em projetos advindos de parcerias como as que a escola manteve, por mais de uma década, com a Superintendência de Limpeza Urbana de Belo Horizonte (SLU) e com a Empresa de Transportes e Trânsito de Belo Horizonte (Bhtrans). Na SLU, os alunos começavam a estagiar ainda no primeiro ano, motivados pelos conteúdos trabalhados na escola. Lá, eles criavam esquetes abordando a temática da coleta seletiva e estas eram apresentadas em escolas públicas e particulares, em praças e ruas da capital, com intuito tanto de divertir quanto de conscientizar a população sobre as questões relacionadas ao lixo. A rotina de trabalho dos estagiários compreendia estudar sobre a coleta seletiva, elaborar os pequenos roteiros de cena a partir de improvisações livres, auxiliar na confecção de adereços e a apresentação pública propriamente dita.

Na Bhtrans, os estagiários participavam de campanhas de conscientização para o trânsito, principalmente em semáforos e ruas da cidade. Um dos recursos utilizados em ambos os casos eram as técnicas circenses (como as pernas de pau e os malabares), muito úteis para a mobilização social e ensinadas aos alunos também no primeiro ano da escola. Ao se formarem, por vezes, os alunos eram promovidos a coordenadores de projetos dentro dessas instituições, justamente pelas habilidades demonstradas para o trabalho em equipe (adquiridas no decorrer do curso), uma vez que o teatro é uma arte eminentemente coletiva. Segundo Vilardouro (2013), saber trabalhar em equipe é uma das características importantes de um animador sociocultural, aproximando-o de

um agente social, pois pratica a animação sociocultural não com sujeitos isolados, mas com grupos com os quais implementa uma atuação unida. Por fim, o animador sociocultural é visto como um mediador, capaz de constituir uma comunicação positiva entre vários indivíduos, grupos, comunidades, instituições sociais e com os organismos públicos [Vilardouro, 2013, p. 26].

Nessa mesma direção, não poderíamos deixar de citar o trabalho realizado pela trupe A Torto e a Direito, que em parceria com a Faculdade de Direito da UFMG atua dentro do Programa Polos de Cidadania há mais de vinte anos, desenvolvendo um trabalho de mobilização social por meio do teatro em escolas e comunidades carentes da capital mineira e do interior do estado de Minas Gerais, apresentando esquetes e espetáculos. Temas difíceis, como violência doméstica e exploração sexual, são 
abordados de maneira lúdica e, ao mesmo tempo, crítica para uma parcela da população com frequente trajetória de vulnerabilidade e exclusão social. No trabalho da trupe temos a oportunidade de ver aplicada, de maneira mais elaborada, boa parte dos princípios de criação descritos neste capítulo, seja pela criação coletiva, ou pelo uso de recursos da cultura popular (como o cordel e o mamulengo).

De outra maneira, temos também as participações desses alunos nos festivais de inverno da UFMG, como monitores na oficina de circo do Festival Jovem. Em 1994, por exemplo, foi proposto pelo Grupo Teatro Kabana ${ }^{4}$ a oficina Esses incríveis arteiros, espalhafatosos, malucados e desbilolados aprendizes de circo. A finalização dessa oficina culminaria em um espetáculo na praça principal de Ouro Preto (Minas Gerais), a Praça Tiradentes, em frente ao Museu da Inconfidência. Assim, partindo da relação com o espaço, sua arquitetura, sua história, foi proposta a pesquisa histórica e a busca do conhecimento pela oralidade como motes para a construção da dramaturgia. Ali, com o auxílio dos monitores e professores, as noções de pertencimento, de aproximação da comunidade eram trazidas para as crianças, aproximando-as também das construções estéticas e demais componentes da cena.

Sempre propiciadas pelas vivências corporais das técnicas circenses, as crianças eram recebidas em rodas de conversas e brincadeiras em que eram trabalhadas suas identidades, suas origens, suas histórias de vida. Por meio desse conhecimento e reconhecimento de si, eram criados e desenvolvidos temas em que as crianças e adolescentes se tornavam coautores de um espetáculo que,

com trapézios, bambolês, pernas de pau, bastões, monociclos e outros elementos circenses, os incríveis arteiros, espalhafatosos, malucados e desbilolados aprendizes contarão a estória de um encontro atemporal entre duas tribos de circo: Uga Uga Circo e Galaxcircus, uma primitiva e a outra intergaláctica. $\mathrm{O}$ estranhamento inicial passa logo que as tribos se dão conta da identidade que há entre elas, graças à linguagem do circo, universal e atemporal. Há então, uma grande festa unindo todos. Nesse momento, as personagens

4 O Grupo Teatro Kabana, sediado na Vila Marzagão desde 1997, teve seu início em 1980. Sua pesquisa é voltada para o teatro de rua, o circo e o teatro de bonecos. Mais informações disponíveis em: <http://www.gtkabana.com.br>. Acesso em: 3 mar. 2019. 
percebem que o espaço físico que ocupam foi marcado por uma história de opressão e tristeza - uma referência ao episódio da Inconfidência Mineira. Então, Uga Uga Circo e Galaxcircus procuram interferir nessa história com a força da linguagem de sonho e fantasia circenses, constituindo-se elemento libertador [UGALAX Circus, 1994, p. 1].

Assim como nesse relato do Festival de Inverno, os alunos trabalharam e continuam trabalhando como estagiários ou como profissionais formados em diversos projetos, sejam de extensão, pesquisa ou socioeducativos, e como monitores de oficinas de teatro e circo. Esse tipo de atuação, principalmente nos projetos sociais, acaba aproximando os alunos também do educador sociocultural.

Das iniciativas mais recentes, há o Teatro\&Cidade - Núcleo de Pesquisa Cênica, formado em 2013 como um grupo de pesquisa e extensão do Teatro Universitário da UFMG. Com suas criações, o grupo procura reforçar que a rua, assim como a cidade e seus espaços públicos, não são vistos, do ponto de vista teatral, como locais de apresentação de obras acabadas. Antes de tudo, são locais de convivência, para serem ocupados das mais variadas formas e ocasiões. Propõe um teatro que aconteça com a cidade, sem que seja preciso fechar ruas ou montar palcos. Um teatro em que a ação dos atores depende de suas capacidades de conquistarem seus espaços e, ao mesmo tempo, da generosidade daqueles que compartilham a construção das cenas, dos jogos, das brincadeiras e das imagens que surgem a cada esquina, a cada olhar, a cada aperto de mão, a cada tombo ou tropeção, a cada risada. O grupo acredita, assim como o diretor, Amir Haddad (2001, p. 153), que

existe um teatro imanente na cidade. Há uma possibilidade teatral imanente no cidadão e nos ritos de convivência, não prevista na vida da cidade e, consequentemente, não considerada, embora continuamente se manifeste - numa festa, numa barraca de cachorro-quente, num camelô que vende alguma coisa, em tudo.

Segundo esse autor, o problema é que se estabeleceu uma divisão entre o teatro e a cidade, entre o artista e o cidadão, sendo essa divisão exatamente o que o Teatro\&Cidade pretende borrar, o que leva o trabalho desse grupo a ter, por natureza, uma relação intrínseca com as dimensões do lazer.

Por fim, as trajetórias profissionais dos autores deste texto - que, além de pertencentes ao quadro atual do corpo docente efetivo do Teatro 
Universitário, formaram-se como atores na mesma escola em meados dos anos de 1990 - ajudam a testemunhar como os profissionais egressos dessa escola, por vezes, ampliam seu campo de atuação em áreas tipicamente ligadas ao que se tem constituído, hoje, como campo do lazer. Ambos os autores deste capítulo trabalharam, por diversas vezes, como monitores de oficinas em projetos socioeducativos, em festivais culturais e em projetos de mobilização social de empresas públicas e privadas, incluindo os aqui anteriormente exemplificados.

Diante do que afirma Isayama $(2005$, p. 15) sobre o fato de que "na atualidade, existe uma tendência à comercialização das propostas de formação profissional, pois o lazer é focalizado como um filão do mercado que abre grandes possibilidades de ganhos", pareceu-nos importante fazer esse rastreamento de como elementos do teatro e do circo, praticados no Teatro Universitário, possuem características que dialogam com o lazer, ressaltando a criação do curso técnico em lazer como um reconhecimento da autonomização do campo que, ao contrário de se ater apenas às demandas mercadológicas, pode, sim, formar profissionais capazes de intervir na realidade de forma crítica e criativa.

\section{Referências}

BIÃo, A. A especificidade da pesquisa em artes cênicas no ambiente universitário brasileiro. In: Congresso Brasileiro de Pesquisa e Pós-Graduação em Artes CÊnicas. São Paulo. Anais... São Paulo: Abrace, 1999. v. 1, p. 254-258.

Cabral, B. Â. V. A prática como pesquisa em espetáculo. Jornal do III Congresso Brasileiro de Pesquisa e Pós-Graduação em Artes Cênicas, Florianópolis, 1-4 ago. 2003.

FÉrAL, J. Teatro e sociedade: em busca de um novo contrato social, teoria e prática. In: Congresso Brasileiro de Pesquisa e Pós-GraduaÇão em Artes Cênicas, 2., 2001. Bahia. Anais... Bahia: Abrace, 2001. v. 2, p. 21-32. Garcia, S. Teoria e prática do teatro. São Paulo: Hucitec, 1988.

HADDAD, A. Reflexões sobre os vinte anos de experiência do grupo de teatro “Tá na Rua”. Trans/Form/Ação, Marília, v. 24, n. 1, p. 153-161, 2001.

IsAACSSON, M. Teatro e universidade: uma integração a ser realizada. Repertório Teatro \& Dança, Bahia, ano 2, n. 3, p. 26-32, nov. 1999.

IsAYAMA, H. F. Um olhar sobre a formação profissional no lazer. Revista Licere, Belo Horizonte, v. 8, n. 1, p. 11-19, 2005. 
Marcus, G. E. O intercâmbio entre arte e antropologia: como a pesquisa de campo em artes cênicas pode informar a reinvenção da pesquisa de campo em antropologia. Revista de Antropologia, São Paulo, v. 47, n. 1, p. 133-158, 2004.

PPP - Projeto Político Pedagógico. Técnico de nível médio em lazer. Belo Horizonte: Teatro Universitário da Universidade Federal de Minas Gerais, 2017.

Santos, C. A. N. L. O currículo dos cursos técnicos de lazer no Brasil: um estudo de caso da formação profissional. 2011. 135f. Dissertação (Mestrado em Lazer) - Escola de Educação Física, Fisioterapia e Terapia Ocupacional, Universidade Federal de Minas Gerais, Belo Horizonte, 2011.

Santos, M. C. L. Transferência de aprendizagem: um percurso entre as técnicas aéreas circenses e a formação do ator. 2006. 171p. Dissertação (Mestrado em Artes) - Escola de Belas Artes da Universidade Federal de Minas Gerais, Belo Horizonte, 2006.

Schmidt, R. A.; Wrisberg, C. Aprendizagem e performance motora: uma abordagem da aprendizagem baseada no problema. 2. ed. Porto Alegre: Artmed, 2001.

Silva, M. S. A formação profissional e o lazer: questões e enfoques. Revista Brasileira de Estudos do Lazer, Belo Horizonte, v. 4, n. 2, p. 38-56, 2017.

Ugalax Circus Esses incríveis arteiros, espalhafatosos, malucados e desbilolados aprendizes de circo. Boletim do Festival, Ouro Preto, n. 28, p. 1.30 jul. 1994.

Vilardouro, C. F. O contributo da animação sociocultural para o desenvolvimento pessoal e social de alunos com necessidades educativas especiais no $1^{\circ}$ ciclo do ensino básico. Dissertação (Mestrado em Ciências da Educação) Universidade Católica Portuguesa, Viseu, 2013. 



\section{CAPÍTULO 16}

\section{ESCOLA DE POSSIBILIDADES SONORAS: 0 LIXO QUE VIROU INSTRUMENTO MUSICAL ${ }^{1}$}

Fernanda Peralta

Regina Café

O homem gera resíduos em todas as suas atividades, desde sempre. Lidar com esses resíduos e com os impactos que ele ocasiona consistem em um grande desafio ao longo do tempo.

Certamente você já se perguntou para onde vão as coisas depois que perdem sua utilidade. E é essa dúvida que suscita as políticas públicas para a solução dos problemas causados pelo consumo indiscriminado e pela disposição inadequada dos resíduos gerados pelas pessoas e pelo setor produtivo.

Neste capítulo, vamos conversar um pouco sobre os resíduos recicláveis e suas possibilidades criativas, mas antes gostaríamos de trazer algumas questões importantes sobre meio ambiente e sociedade de consumo.

\section{0 que é ambiente?}

Para as Nações Unidas, meio ambiente é o conjunto de componentes físicos, químicos, biológicos e sociais capazes de causar efeitos diretos ou indiretos sobre os seres vivos e as atividades humanas, em um prazo curto ou longo.

No Brasil, meio ambiente é definido como o conjunto de condições, leis, influências e interações de ordem física, química e biológica, que

1 Agradecemos àqueles que colaboraram com este texto: Ângela Canal, Wellington Coelho, Pedrinho Martins, Felipe Lopes, Regis Franco, André Correa. Imagens: Rodrigo Anis. 
permite, abriga e rege a vida em todas as suas formas. Esse conceito está definido pela Política Nacional de Meio Ambiente, instituída pela lei n. 9.795/1999.

Importa afirmar que meio ambiente é um sistema natural e social, onde o homem é parte integrante desse sistema e responsável por sua conservação. Nesse sentido, trabalhamos com o fato de que o homem (ser social) não está apartado da natureza, mas sim faz parte dela.

Somos parte do ambiente e responsáveis diretos por sua preservação, portanto nossas ações diárias e o padrão de desenvolvimento adotado determinam o tamanho e o tipo do impacto ambiental gerado.

À medida que avançamos nas áreas tecnológicas e científicas, fomos criando lacunas e nos afastando da nossa essência. Torna-se, portanto, urgente e necessário o resgate de princípios que nos auxiliem a entender nosso real pertencimento no sistema planta Terra, onde devemos construir nossa participação cidadã pela sua manutenção em seus aspectos ambiental, social e econômico.

O modelo de desenvolvimento com base no método científico, no modelo racional, capitalista excludente, trouxe consequências importantes para o atual cenário em que vivemos:

- o censo comum de dominação da natureza pelo homem;

- $\quad$ a inversão dos valores e sua desconexão com a realidade;

- a degradação moral;

- a separação entre conhecimento científico e o saber popular com a consequente desimportância deste último;

- a vida passa a ser uma luta por espaço e o mundo torna-se extremamente competitivo;

- desvalorização da vida e supervalorização do status;

O século XXI caracteriza-se por uma forte crise ambiental: já percebemos a necessidade de mudança de hábitos e de padrões anteriormente dados como certos e imutáveis; entendemos que muitos de nossos laços são frágeis e que uma mudança moral, ética, racional e espiritual torna-se fundamental para que possamos reverter o quadro de degradação ambiental e de exclusão social em que se encontra o planeta.

Nesse contexto, a educação ambiental crítica e emancipatória tem papel fundamental na compreensão de novos conceitos, valores, nível de envolvimento dos atores sociais nas questões socioambientais e no desenvolvimento de mudanças significativas de comportamento e de 
formas de enfrentamento dessa problemática e na busca pelo equilíbrio socioambiental.

\section{Consumo, consumismo, sociedade de}

\section{consumo e consumo consciente}

Para satisfazer nossas necessidades diárias adquirimos bens e serviços. Peças de vestuário, itens de alimentação, moradia, meios de transporte, bem-estar etc. são adquiridos por meio do fenômeno denominado consumo. Até aí, tudo bem. O problema é quando esse consumo vem dissociado de uma análise crítica dos meios de produção, da origem do produto e dos impactos socioambientais gerados desde a produção até o consumo direto, passando pelo transporte, armazenamento e venda.

Outro grande problema é quando, além de não nos importarmos com a origem daquilo que consumimos, também não nos importamos com o destino que daremos às coisas depois que elas não nos servirem mais. E igualmente ruim é o consumo por impulso, quando não precisamos daquele produto ou serviço e só o adquirimos por impulso, para nos sentirmos melhor, para atender a uma necessidade de status social. Nesse caso, temos o consumismo.

Dizemos que a sociedade de consumo tem sua base no consumo excessivo de bens e serviços em virtude de a oferta ser maior que a procura. Esse modelo de sociedade caracteriza-se pelo sistema capitalista, no qual a facilidade de acesso ao crédito e estratégias de marketing agressivas "convencem" as pessoas a adquirirem aquilo que elas não precisam.

Reparem, por exemplo, nas campanhas de bebidas alcoólicas: são voltadas, em geral, para o público jovem, com muita informação e movimento, em que a mensagem clara é "beba para se transformar em alguém agradável, sociável e querido por todos”. Da mesma forma, as propagandas voltadas para o público infantil possuem um apelo enorme às cores, personagens e desenhos atraentes. São formas eficientes de "convencer" o público a adquirir produtos que talvez ele não esteja precisando de fato, mas é tudo tão atraente que se torna irresistível para a maioria dos consumidos desatentos.

Quando nos preocupamos realmente com tudo que consumimos e passamos a adotar uma postura mais atenta e crítica em relação às questões ambientais envolvidas nos meios e produção, conseguimos alcançar o patamar do consumo consciente. Aqui se estabelecem exigências por 
parte dos consumidores quanto à origem do produto, se há mão de obra escrava envolvida, quanto de energia aquele tipo de produto necessita para ser produzido, se a fabricação envolve materiais de origem reciclável, se o produto é produzido o mais próximo possível do local de consumo etc.

Repensar nossos hábitos e atitudes perante a aquisição de bens e serviços é uma postura simples e de suma importância para a conservação ambiental no que diz respeito ao papel do cidadão nesse processo. No entanto, cabe-nos exigir do poder público o desenvolvimento de políticas de incentivo à produção mais limpa e ambientalmente adequada dos bens e serviços, além da fiscalização eficiente e eficaz do setor produtivo.

\section{0 conceito dos 3 Rs - reduzir, reutilizar e reciclar}

Os 3 Rs são um importante conceito que remete ao consumo consciente, ou seja, ao hábito de pensar antes de consumir: se é realmente necessário adquirir determinado produto; se é possível reutilizar sua embalagem; ou se é um produto passível de reciclagem pós-consumo. Assim, com base nessa análise crítica, tomar a decisão de adquiri-lo ou não. Trata-se de um exercício diário que ao longo do tempo vai incorporando-se aos nossos hábitos, proporcionando instrumentos para uma visão socioambiental mais crítica que vai determinar nossas escolhas.

E por que os 3 Rs são expressos nesta ordem: reduzir, reutilizar e reciclar?

Reduzir o consumo para gerar menos resíduos e diminuir o desperdício. Assim, compramos menos e melhor, além de diminuirmos a geração de resíduos destinados aos aterros sanitários. Reutilizar as embalagens para outros fins, dando novos significados a produtos que seriam encaminhados para o descarte. Em vez de transformar-se em resíduo, essa embalagem pode ser reutilizada em casa ou tornar-se uma peça de artesanato nas mãos dos mais criativos e talentosos, até mesmo podendo promover trabalho e renda.

Reciclar é o termo utilizado para o processo de transformação das propriedades físico-químicas dos resíduos; portanto, o cidadão não recicla os produtos, mas sim os separa para serem encaminhados à reciclagem por meio da coleta seletiva. Esse sistema gera trabalho e renda para os catadores de materiais recicláveis, aumenta a vida útil dos aterros sanitários, diminui os impactos ambientais pela extração de matéria-prima, economiza água e energia, entre outros benefícios. 


\section{Economia circular}

Inspirada nas noções de economia verde, ecologia industrial e de desenvolvimento sustentável, a economia circular é um conceito que propõe o desenvolvimento e a criação de produtos cujos materiais sejam mantidos no ciclo produtivo, além da reutilização dos resíduos industriais como matéria-prima para produção de outros produtos, seja na mesma indústria que gerou o resíduo ou em outra.

Por meio do conceito de economia circular, pretende-se otimizar os processos produtivos, gerando menos resíduos e economizando recursos naturais, além de proporcionar o aumento da vida útil dos produtos.

\section{A geração de resíduos e seus impactos ambientais}

Do nascimento até a morte, o homem gera resíduos, portanto o lixo e os dejetos não são problemas novos ou somente dos tempos atuais. As soluções de descarte ambientalmente adequadas e seguras é que podem ser consideradas preocupações atuais. Mesmo porque, quando do surgimento do homem na terra, os resíduos gerados por suas atividades possuíam características bastante diferentes dos resíduos que hoje conhecemos: eram resíduos de origem orgânica, que eram facilmente incorporados à natureza em seu descarte e decomposição.

Com a evolução do homem e de suas atividades ao longo da história, os resíduos gerados assumiram outras características, as quais já não se incorporavam com facilidade à natureza, sendo necessários descartes em locais distantes das atividades humanas, geralmente nas periferias das cidades que começavam a crescer, com sua população. Considerando que a maioria das cidades eram erguidas às margens de importantes cursos hídricos, a disposição inadequada de resíduos causou a poluição desses corpos d'água, bem como do lençol freático, observando-se grandes ocorrências de doenças ligadas à poluição hídrica e à proliferação de vetores.

Registros históricos demonstram que a relação do homem com os resíduos gerados por suas atividades foi pautada por uma visão de incômodo, de rejeição aos seus próprios dejetos, e não necessariamente por compreender a relação entre saúde pública e gerenciamento adequado de resíduos.

As primeiras civilizações determinavam que o lixo e dejetos humanos e de animais deveriam ser dispostos em áreas localizadas fora das cidades, as quais eram depois recobertas com terra. $\mathrm{O}$ primeiro aterro 
controlado da história teria sido construído na Ilha de Creta, na Grécia, cerca de 3.000 a.C. Daí em diante, a Europa passa a adotar diversas ações voltadas para a limpeza urbana e aterramento ou incineração de resíduos, enquanto suas cidades sofriam com epidemias que dizimavam grande parte de suas populações.

Somente na primeira metade do século XIX, após a publicação do Relatório a respeito da pesquisa sobre a condição sanitária da população trabalhadora na Grã-Bretanha (Report of an Inquiry into the Sanitary Condition of the Labouring Population of Great Britain), de autoria de Edwin Chadwick, é que ficou clara e definitivamente aceita a relação entre lixo e saúde pública, o que levou a Europa a desenvolver sistemas de gerenciamento de resíduos.

No Brasil, cujo desenvolvimento das cidades e diversificação das atividades humanas se deram bem depois do desenvolvimento europeu, registros apontam a destinação de lixo e dejetos diretamente nos rios, no mar. Nas grandes cidades, os moradores conviviam com lixo depositado em becos e vielas.

Durante o segundo reinado, principalmente na segunda metade do século XIX, o Brasil passou por um grande movimento de urbanização e modificação de hábitos, inclusive de higiene, seguindo o exemplo de cidades europeias. Mas, ainda assim, não eram ações de grande impacto e a população não se preocupava muito em atender às regras impostas pelo governo imperial. As atividades de limpeza e higiene eram vistas como subalternas e, por conseguinte, desenvolvidas por escravos.

Ainda na primeira metade do século xIx, o Rio de Janeiro recebeu muitas benfeitorias: a cidade foi arborizada em 1820; nos anos de 1853 e 1854, havia paralelepípedos nas ruas e iluminação a gás; a rede de esgoto chegou em 1862 e as casas passaram a ser abastecidas com água em 1874 (Gomes, 2013).

A partir de 1880, o gerenciamento de resíduos passa a assumir um papel mais significativo no Brasil, com a publicação do decreto n. 3.024, que tratava da limpeza das cidades. Esse serviço foi executado por Aleixo Gary. Daí o nome da profissão de gari, atribuída aos profissionais de limpeza urbana (MonTEIRo et al., 2001).

De 1880 aos dias atuais, os serviços de manejo de resíduos sólidos evoluíram bastante, mas ainda estão aquém do ideal, de forma que possa garantir a preservação dos recursos naturais e a saúde da população. Ainda encontramos municípios que convivem com uma realidade bastante adversa no que diz respeito à gestão dos resíduos sólidos: os 
resíduos são dispostos em vazadouros a céu aberto, os serviços de coleta domiciliar e limpeza de logradouros são irregulares ou, em muitos casos, inexistentes. Não há tratamento dos resíduos provenientes dos serviços de saúde e da construção civil. Esse conjunto de fatores, aliado à falta de planejamento, torna a gestão ineficiente e ineficaz, além de absorver grande parte do orçamento municipal. Embora possamos observar municípios que avançaram na gestão de resíduos sólidos, utilizando tecnologias adequadas à sua realidade local e realizando investimentos em prol da conservação ambiental e do bem-estar da população.

Com a promulgação de legislação específica para a área de saneamento e de gestão compartilhada - Lei de Consórcios Públicos n. 11.107 (BRAsil, 2005); Lei do Saneamento Básico n. 11.445 (Brasil, 2007) e a lei n. 12.305 (Brasil, 2010), que institui a Política Nacional de Resíduos Sólidos (PNRS) -, o Brasil entra em uma nova fase no que tange ao gerenciamento de resíduos sólidos: obrigatoriedade de encerramento e remediação dos lixões, com estados e municípios obrigados a elaborar seus planos de gestão de resíduos e implantar a coleta seletiva para redução gradativa de recicláveis dispostos em aterros sanitários.

Estamos iniciando um processo importante de avanços na área de saneamento, em que as responsabilidades são compartilhadas e as obrigações definidas, cabendo ao poder público elaborar políticas públicas eficientes e eficazes, em prol do bem-estar da população. E, nesse processo de responsabilidade compartilhada pelo bem comum, cabe ao cidadão a postura crítica em relação à execução de tais políticas e à adoção de uma conduta ambientalmente adequada perante suas necessidades de consumo e de posicionamento na sociedade.

\section{0 marco legal da gestão de resíduos no Brasil}

A PNRS (BRASIL, 2010) representa um avanço e um desafio para a sociedade brasileira, pois necessita da participação de todos, instituindo um novo marco regulatório para a gestão dos resíduos no país, que estabeleceu os princípios com vistas à gestão integrada e ao gerenciamento ambientalmente adequado dos resíduos sólidos.

A lei dispõe sobre os "princípios, objetivos e instrumentos, bem como sobre as diretrizes relativas à gestão integrada e ao gerenciamento de resíduos sólidos, incluídos os perigosos, às responsabilidades dos geradores e do poder público e aos instrumentos econômicos aplicáveis" (BRASIL, 2010). 
Em seu artigo $6^{\circ}$ encontram-se listados os princípios para a implementação da PNRS, entre os quais se destacam a responsabilidade compartilhada pelo ciclo de vida dos produtos e o reconhecimento do resíduo sólido, reutilizável e reciclável, como um bem econômico e de valor social, gerador de trabalho e renda e promotor de cidadania.

A ordem hierárquica a ser adotada no Brasil para o correto gerenciamento dos resíduos sólidos está definida no artigo $9^{\circ}$ da PNRS. Para ilustrar, vamos pensar em algumas maneiras de como colocar em prática os quatro primeiros itens da hierarquia da gestão de resíduos:

1. Não geração: a não geração de resíduos diz respeito a evitar a geração, por exemplo, evitando comprar produtos que venham com embalagens excessivas ou desnecessárias. Outra forma de não geração é a utilização de canecas ou copos não descartáveis em vez de copos plásticos descartáveis, muito comuns em festas e ambientes de trabalho.

2. Reduzir: uma das formas de reduzir a geração de resíduos é manter uma composteira doméstica, que transforma os resíduos orgânicos em adubo, fazendo com que esses resíduos não necessitem ser transportados até um aterro sanitário. Observe que nesse caso há uma dupla economia para o município: com o transporte e com a disposição final.

3. Reutilização: a reutilização ocorre quando um produto é utilizado para o mesmo ou para outros fins, sem alterar sua forma ou composição. Um bom exemplo são os potes de vidro, que podem ser utilizados para guardar mantimentos, ou mesmo a garrafa plástica de água, que pode ser utilizada dezenas de vezes até ser jogada fora.

4. Reciclar: depois de esgotadas as possibilidades anteriores, deve-se facilitar e encaminhar os resíduos para a reciclagem ${ }^{2}$. No caso dos resíduos recicláveis domiciliares, eles devem ser colocados para a coleta seletiva, conforme regras estabelecidas pelo município.

2 A reciclagem é o processo de transformação dos resíduos sólidos que envolve a alteração de suas propriedades físicas, físico-químicas ou biológicas, com vistas à transformação em insumos ou novos produtos. 
Ao diferenciar o resíduo sólido do rejeito, a PNRS proporciona um grande estímulo ao reaproveitamento e à reciclagem dos resíduos sólidos gerados. De acordo com a PNRS, em seu artigo $3^{\circ}$, inciso $\mathrm{xV}$, rejeitos são os resíduos sólidos que, depois de esgotadas todas as possibilidades de tratamento e de recuperação por processos tecnológicos disponíveis e economicamente viáveis, não apresentem outra possibilidade que não a disposição final ambientalmente adequada. Podemos entender então que só podemos denominar resíduo sólido o resíduo que poderá de alguma forma ser tratado e recuperado.

\section{A educação ambiental com foco em resíduos sólidos}

A Constituição Federal, em seu artigo 225, nos diz que “Todos têm direito ao meio ambiente ecologicamente equilibrado, bem de uso comum do povo e essencial à sadia qualidade de vida, impondo-se ao Poder Público e à coletividade o dever de defendê-lo e preservá-lo para as presentes e futuras gerações" (BRASIL, 1988).

Nesse sentido, todos nós temos o direito de usufruir de um meio ambiente sadio e equilibrado e, ao mesmo tempo, o dever de defendê-lo e preservá-lo. Esse é o princípio da gestão ambiental pública.

De acordo com a lei federal n. 9.795, de 27 de abril de 1999, que institui a Política Nacional de Educação Ambiental,

entendem-se por educação ambiental os processos por meio dos quais o indivíduo e a coletividade constroem valores sociais, conhecimentos, habilidades, atitudes e competências voltadas para a conservação do meio ambiente, bem de uso comum do povo, essencial à sadia qualidade de vida e sua sustentabilidade [BrasiL, 1999].

Ainda de acordo com a referida lei, em seu artigo $3^{\circ}$, inciso I,

cabe ao Poder Público, nos termos dos arts. 205 e 225 da Constituição Federal, definir políticas públicas que incorporem a dimensão ambiental, promover a educação ambiental em todos os níveis de ensino e o engajamento da sociedade na conservação, recuperação e melhoria do meio ambiente [BRASIL, 1999].

Segundo o documento final da Conferência de Tbilisi, antiga União Soviética, que aconteceu em 1977, devemos observar que "o conceito de meio ambiente abarca uma série de elementos naturais, criados pelo 
homem, e sociais, da existência humana, e que os elementos sociais constituem um conjunto de valores culturais, morais e individuais, assim como de relações interpessoais na esfera do trabalho e das atividades de tempo livre" (Unesco; PnUma, 1977).

A garantia de sustentabilidade dos processos de educação ambiental passa, invariavelmente, pela organização, ação sistemática e continuidade de propostas e pela descentralização e incentivo à construção coletiva de proposituras locais, com base na etapa inicial de diagnóstico.

Uma ação importante é a criação de sistemas de rede, que fazem com que todos os indivíduos e instituições participem, promovendo a interação entre eles e a apropriação de questões locais, além do empoderamento para tomada de decisões coletivas e engajadas.

A educação ambiental com foco em resíduos sólidos não aborda a questão meramente individual, uma vez que a geração e o descarte de resíduos são considerados problemas coletivos de interesse público, portanto só encontraremos uma saída com o envolvimento de toda a sociedade.

Entendemos caber fundamentalmente ao Estado uma intervenção contundente nesse intuito, por tratar-se de uma questão relevante, coletiva e de interesse público. Ao Estado cabe definir com clareza políticas públicas de resíduos sólidos com vistas a práticas para redução do consumo, coleta seletiva, tratamento e disposição final de resíduos sólidos, até mesmo com grupos econômicos e com toda a sociedade.

Nesse contexto, a educação ambiental crítica e emancipatória assume papel fundamental no processo de construção de novas posturas, de novos conhecimentos e de uma nova cultura de consumo e descarte de resíduos. Nesse sentido, e entendendo a necessidade de trabalhar a questão dos resíduos sólidos nas comunidades jovens, surge o projeto Escola de Possibilidades Sonoras Regina Café.

\section{Escola de Possibilidades Sonoras - o projeto}

O projeto Escola de Possibilidades Sonoras nasce no ano 2000 da necessidade de se desenvolver ações de educação ambiental com foco em resíduos sólidos, utilizando a arte como veículo de integração e promoção das questões socioambientais. 
Transformando resíduos recicláveis em instrumentos musicais, a versatilidade desse projeto permite que sua formação se dê tanto com uma oficina pontual quanto com um curso de constituição profissional.

Considerando a temática ambiental, o projeto estimula a criação de grupos musicais e associa ao tema ambiental a expressão da cultura popular brasileira e mundial valendo-se de diversos estilos, como samba, funk, baião, rock, frevo, maracatu, samba-reggae, entre outros ritmos, com ações de arte-educação e de reaproveitamento desenvolvidas ao longo de atividades pontuais, como oficinas, palestras e ações de curto, médio e longo prazos.

As aulas de música abordam teoria musical, percepção rítmica, construção de instrumentos com materiais reaproveitáveis, composições musicais, melodias e harmonias, incentivando a criatividade, a autoestima, o resgate da cidadania e, consequentemente, a comunicação de massa e a possibilidade de geração de renda.

O projeto Escola de Possibilidades Sonoras propõe a transformação do jovem em multiplicador por meio de atividades de divulgação e propagação dos resultados obtidos, estimulando a inclusão social e econômica do público-alvo. Uma das ferramentas propostas pelo projeto para garantir essa inclusão foi a gravação do CD/DVD com músicas inéditas compostas e gravadas pelos alunos, disponibilizado ao público de forma gratuita em diversas mídias digitais e com distribuição em eventos e encontros comunitários promovidos pelo projeto e seus parceiros.

A realidade sociocultural das comunidades cariocas traz o grande desafio de trabalhar políticas públicas de inclusão com vistas à diminuição ou, pelo menos, a minimização dos impactos negativos da vulnerabilidade social experienciada por jovens residentes nessas comunidades. $\mathrm{O}$ projeto Funk Verde atua como ação de educação ambiental em ambiente não formal e relaciona aspectos ambientais e sociais presentes no cotidiano desses jovens.

Ao fomentar no grupo a ressignificação dos resíduos por meio de sua transformação e reaproveitamento, o enfrentamento de questões muito presentes em nossa sociedade e na vida desses jovens é fortalecido: humanização das relações, autoestima, acesso à cultura e ao empoderamento para a cidadania, respeito, comunicação não violenta, entre outros temas.

Sabedores de que os jovens em situação de vulnerabilidade social são alvos fáceis do crime organizado e da violência, o projeto oferece 
uma alternativa de suma importância no presente e no futuro de nossa sociedade, uma vez que propõe ser um espaço que une questões ambientais, arte, desenvolvimento pessoal e incentiva a geração de renda por meio da música e de confecção de instrumentos.

Trata-se, portanto, de um caso de sucesso de um projeto socioambiental idealizado pela artista visionária e ativista Regina Café e proposto ao Estado para execução em grande escala como política pública de educação ambiental e atuação cidadã.

\section{Considerações finais}

A arte é tradicionalmente reconhecida como uma poderosa ferramenta de promoção da educação e da construção do conhecimento em virtude da multidisciplinaridade com que aborda os temas propostos, sendo um excelente recurso pedagógico para trabalharmos conhecimentos científicos e valores sociais. A promoção do lazer como eixo condutor da reconstrução da identidade sociocultural dos alunos atendidos pelo projeto promove a inclusão do convívio social, no qual os alunos se percebem seres talentosos e criativos, sendo capazes de ocupar espaços de desenvolvimento e articulação local para promoção de melhorias em suas comunidades, graças ao empoderamento e aos sentimentos de pertencimento e responsabilização coletiva.

Nesse sentido, a música torna-se o principal processo metodológico do projeto Escola de Possibilidades Sonoras para desenvolver as atividades, proporcionando, para além da atuação socioambiental, uma nova realidade sociocultural para seus participantes, ao ampliar seu senso crítico e suas oportunidades culturais e de lazer. Além de recurso metodológico, a música reconhece e legitima a pluralidade de identidade dos grupos e dos indivíduos, promovendo o lazer como atividade meio para o processo de ensino-aprendizagem, no qual os procedimentos didático-metodológicos propostos estão relacionados à elaboração de conteúdos aliados ao aspecto cultural-cognitivo dos alunos, formando o conhecimento por meio de diferentes perspectivas.

Ao longo dos anos de execução, o projeto Escola de Possibilidades Sonoras vem cumprindo sua missão e obtendo expressivos resultados ao proporcionar possibilidades de mudanças de perspectivas em seus participantes, estimulando a busca por conhecimento, promoção para atitudes de mudanças nas comunidades em que vivem e maior proximidade com a cultura musical mundial. 


\section{Depoimentos}

Olha que grande sacada da Regina Café, transformando bombona e outros recicláveis em instrumentos musicais e passando o que tem de melhor, seu conhecimento, para esses jovens das comunidades. Muito feliz com seu trabalho, e que Deus ilumine a cada dia seu talento e perseverança em querer ajudar nossas crianças que tanto precisam de colo musical

Mestre Odilon Costa - mestre de bateria, arranjador, percussionista e autor do livro Batuque carioca.

Eu estou no meu quinto mandato como deputado e em dois deles fui secretário de Meio Ambiente. Ao longo desse período, eu tive a honra de trabalhar com a Regina Café em projetos que me enchem de alegria. Lá se vão dezoito anos... A Regina sempre foi uma artista multiplicadora, e usar a música como instrumento de esperança para jovens carentes de conhecimento e motivação era o que a gente queria para fazer do socioambiental a nossa maior ferramenta de trabalho. E assim criamos o Dalailata, depois o Ecomusiva, o Funk Verde no De Olho no Lixo, e agora os Protetores das Unidades de Conservação, um projeto novo e do qual muito me orgulho de ver em fase de conclusão. São iniciativas que fazem a diferença na vida de jovens, crianças, adultos e até de idosos. Não tem idade!! A Regina ensina essa rapaziada, essa moçada, a transformar materiais que iriam para o lixo em instrumentos musicais, de percussão pra valer, não é brincadeira de escola, não! É música e som de qualidade! E não é só isso! Eu assino embaixo do trabalho dela porque a cada projeto que fazemos, nós transformamos vidas! Alunos que através da música e da capacitação se sentiram motivados a aprender a ler e escrever, a buscar um novo emprego... Tiveram a autoestima elevada. Não é um sonho, é uma realidade, e é assim que a Regina vai ajudando a essa turma toda a ter conhecimento, consciência e mudança de comportamento em relação ao meio ambiente, que é, sem dúvida nenhuma, a maior riqueza que Deus nos deu nesse planeta Terra! Eu só tenho a agradecer a Regina Café por acreditar na nossa parceria e por não desistir diante das adversidades. O meio ambiente merece muitas Reginas!! André Corrêa - administrador de empresas, mestre em administração pública, deputado estadual no Rio de Janeiro, tendo sido eleito pela primeira vez em 1998 e, em 2018, seguiu para seu sexto mandato consecutivo. 
Regina Café tem uma intuição afiada ao agregar talentos ensinadores e aprendizes talentosos. E, para produção de gravação, também tem o faro para atingir o objetivo com a clareza de quem sabe o que quer. Marcelo Bernardes - arranjador, saxofonista e diretor musical de estúdio.

\section{Como confeccionar instrumentos com materiais recicláveis}

\section{Cuíca com Material Reciclável}

\begin{tabular}{|c|c|}
\hline Materiais: & Ferramentas: \\
\hline - PVC e 100 ou e 200 & \multirow{12}{*}{ - Serrote ou arco de serra } \\
\hline - Palito de bambu (no máximo $20 \mathrm{~cm}$ ) & \\
\hline - Couro & \\
\hline - Lixa & \\
\hline - PVC e 100 ou e 200 & \\
\hline - Palito de bambu (no máximo $20 \mathrm{~cm}$ ) & \\
\hline - Couro & \\
\hline - Lixa & \\
\hline $\begin{array}{l}\text { - Braçadeira ou aro de metal (na mesma largu- } \\
\text { ra do PVC que você escolheu) }\end{array}$ & \\
\hline - Faca sem ponta & \\
\hline - Linha grossa ou barbante & \\
\hline - Caneta & \\
\hline
\end{tabular}

\section{Passo a passo}

\section{Base de PVC}

1. Pegue o tubo de PVC limpo

2. Com a fita métrica, meça $20 \mathrm{~cm}$ e marque

3. Corte com o serrote ou com o arco de serra e lixe as bordas 


\section{Empachando}

1. O couro deve estar em formato circular, quase um palmo maior do que a circunferência do PVC

2. Umedeça o couro (cuidado para não encharcar!)

3. Marque o centro do couro com uma caneta

4. Posicione o palito de bambu na marca central e amarre o palito no couro com a linha grossa, fazendo um nó bem apertado (se souber, faça o nó de porco)

5. Deixe secar ao sol

6. Pegue o aro ou braçadeira, já na medida que fique bem apertado para encaixar no tubo de PVC cortado

7. Posicione o aro sobre o couro e centralize

8. Enrole uma das pontas no aro e estique o couro, puxe pelo lado oposto e enrole

9. Vai repetindo até tensionar o couro e encaixe o aro no tubo de PVC cortado

10. Deixe bem esticado

11. Pinte

12. Com um paninho molhado com água, toque a cuíca friccionando o pano no palito

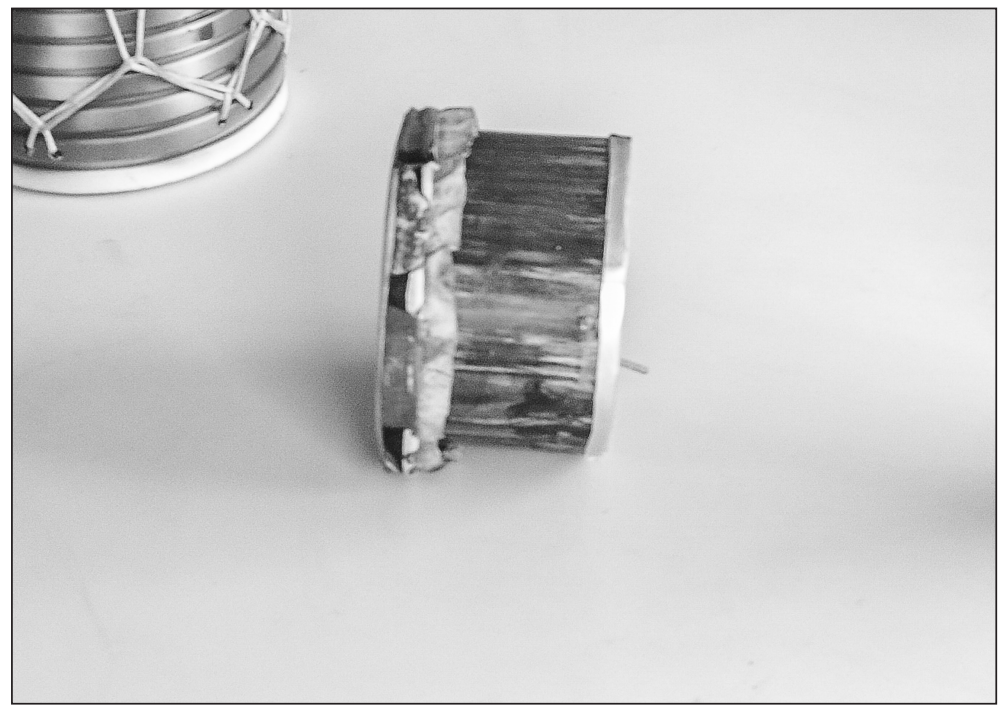

Figura 1: Cuíca confeccionada com material reciclável. 


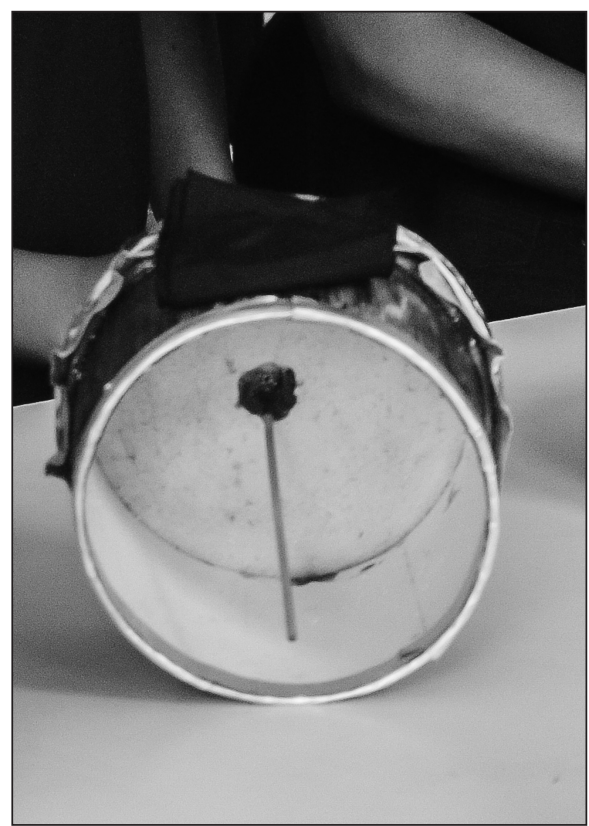

Figura 2: Cuíca confeccionada com material reciclável (imagem da parte interna do instrumento).

\section{Referências}

Brasil. Constituição da República Federativa do Brasil. Brasília, DF: Senado Federal: Centro Gráfico, 1988. Disponível em: <http://www.planalto.gov.br/ ccivil_03/constituicao/ConstituicaoCompilado.htm>. Acesso em: 3 mar. 2019.

Brasil. Lei n. 9.795, de 27 de abril de 1999. Dispõe sobre a educação ambiental, institui a Política Nacional de Educação Ambiental e dá outras providências. Diário Oficial da União, Brasília, DF, 28 abr. 1999. Disponível em: <http://www.planalto.gov.br/ccivil_03/LEIS/19795.htm>. Acesso em: 3 mar. 2019.

BrASIL. Lei n. 11.107, de 6 de abril de 2005. Dispõe sobre normas gerais de contratação de consórcios públicos e dá outras providências. Diário Oficial da União, Brasília, DF, 7 abr. 2005. Disponível em: <http://www.planalto. gov.br/ccivil_03/_Ato2004-2006/2005/Lei/L11107.htm>. Acesso em: 3 mar. 2019.

BrASIL. Lei n. 11.445, de 5 de janeiro de 2007. Estabelece as diretrizes nacionais para o saneamento básico, cria o Comitê Interministerial de Saneamento 
Básico, altera a lei n. 6.766, de 19 de dezembro de 1979, a lei n. 8.036, de 11 de maio de 1990, a lei n. 8.666, de 21 de junho de 1993, e a lei n. 8.987, de 13 de fevereiro de 1995, e revoga a lei n. 6.528, de 11 de maio de 1978. Diário Oficial da União, Brasília, DF, 8 jan. 2007. Disponível em: <http://www.planalto.gov.br/ccivil_03/_Ato2007-2010/2007/Lei/L11445.htm>. Acesso em: 3 mar. 2019.

Brasil. Lei n. 12.305, de 2 de agosto de 2010. Institui a Política Nacional de Resíduos Sólidos; altera a lei n. 9.605, de 12 de fevereiro de 1998; e dá outras providências. Diário Oficial da União, Brasília, DF, 3 ago. 2010. Disponível em: <http://www.planalto.gov.br/ccivil_03/_ato2007-2010/2010/lei/112305. htm>. Acesso em: 3 mar. 2019.

Gomes, L. 1889 - como um imperador cansado, um marechal vaidoso e um professor injustiçado contribuíram para o fim da Monarquia e a Proclamação da República no Brasil. São Paulo: Globo, 2013.

Gonçalves, P. A cultura do supérfluo. Rio de Janeiro: Garamond, 2011.

Monteiro, J. H. P. et al. Manual de gerenciamento integrado de resíduos sólidos. Rio de Janeiro: IвAM, 2001.

Touraine, A. Igualdade e diversidade: o sujeito democrático. Bauru: Edusc, 1998.

UnesCo - Organização das Nações Unidas para a Educação, a Ciência e a Cultura; Pnuma - Programa das Nações Unidas para o Meio Ambiente. Conferência Intergovernamental sobre Educação Ambiental. Tbilisi, Geórgia, 14 a 26 de outubro de 1977. Disponível em: http://www.fzb.rs.gov.br/upload/ 20130508155354 tbilisi.pdf >. Acesso em: 25 mar. 2019. 



\section{SOBRE OS ORGANIZADORES E AUTORES DA OBRA}

CHRISTIANNE LUCE GOMES é professora Titular na UFMG. É docente em diferentes cursos de graduação, no mestrado e no doutorado interdisciplinar em Estudos do Lazer. Desenvolve atividades acadêmicas em diferentes cursos de graduação, mestrado e doutorado no Programa de Pós-Graduação Interdisciplinar em Estudos do Lazer. É doutora em educação, com pós-doutorado em ciências políticas e sociais e estágio sênior na Universidade de Barcelona (bolsa da Coordenação de Aperfeiçoamento de Pessoal de Nível Superior CApes, 2018). Realizou o curso de formação da Escola Livre de Cinema de Belo Horizonte. Pesquisadora do Conselho Nacional de Desenvolvimento Científico e Tecnológico ( $\mathrm{CNPq}$ ) (produtividade em pesquisa), da Fundação de Amparo à Pesquisa do Estado de Minas Gerais (FAPEmig) (Programa Pesquisador Mineiro), da Rede Cedes do Ministério do Esporte e líder do Grupo de Pesquisa LuCE - Ludicidade, Cultura e Educação (UFMG/CNPq).E-mail: chris@ufmg.br

JOSÉ ALFREDO OLIVEIRA DEBORTOLI é professor na Escola de Educação Física, Fisioterapia e Terapia Ocupacional (EEFFTO/UFMG). Docente no Programa de Pós-Graduação Interdisciplinar em Estudos do Lazer e no mestrado profissional da Faculdade de Educação - Promestre, ambos na UFMG. Doutorado em educação na Pontifícia Universidade Católica do Rio de Janeiro (PUC-Rio) e pós-doutorado em antropologia social na Universidade de Brasília (UnB). Participa da Coordenação do Núcleo de Estudos sobre Aprendizagem na Prática Social (NAPrática). Tem dedicado estudos à relação educação, corpo e cultura, com atenção especial às experiências de infância em suas relações sociais.E-mail: dbortoli@eeffto.ufmg.br

LUCIANO PEREIRA DA SILVA é professor na EEFFTO/UFMG. Docente no Programa de Pós-Graduação Interdisciplinar em Estudos do Lazer da UFMG. Doutor em educação pela UFMG. Participa do Grupo de Estudo e Pesquisa em Políticas Públicas de Esporte e Lazer - Polis/UFMG. Desenvolve pesquisas na área de políticas públicas de esporte e lazer e história das práticas corporais. E-mail:1pereira45@hotmail.com

ANA MARIA COSTA BEBER realiza estágio pós-doutoral no Programa de Pós-Graduação em Turismo e Hospitalidade, Universidade de Caxias do Sul 
(UCS). Doutora pelo Programa de Pós-Graduação em Desenvolvimento Rural (Universidade Federal do Rio Grande do Sul - UFRGS), mestre em turismo (UCS), graduada em turismo e em hotelaria (UCS). Membro do Grupo de Estudos GePaC.E-mail: galáxia_ana@hotmail.com

BERNARDO LAZARY CHEIBUB é professor no mestrado e no bacharelado em turismo da UFF. Doutor em história, política e bens culturais pela Fundação Getúlio Vargas (FGV), com período sanduíche na Universidade de Surrey. É mestre em estudos do lazer pela UFMG, especialista em jogos cooperativos pelo Centro Universitário Monte Serrat (UnimonTE), especialista em lazer pelo SENAC-SP, bacharel em turismo pela Anhanguera Educacional. Líder do grupo de pesquisa MobLaTus - Mobilidades, Lazer e Turismo Social. Coordena os projetos de extensão Turismo Social UFF e de pesquisa Lazer, Turismo e Demandas Sociais. Sócio fundador da Associação Brasileira de Pesquisa e Pós-Graduação em Estudos do lazer (ANPEL).E-mail: bernardocheibub@id.uff.br

CORIOLANO P. DA ROCHA JUNIOR é pós-doutorado em história pela Universidade de Lisboa (2018), doutor em história pela Universidade Federal do Rio de Janeiro (UFRJ) (2011), mestre em educação física pela Universidade Gama Filho (2000), licenciado em educação física pela Universidade do Estado do Rio de Janeiro (UerJ)(1993), professor da graduação e do Programa de Pós-Graduação em Educação da Faculdade de Educação da Universidade Federal da Bahia (UFBA).E-mail: coriolanojunior@uol.com.br

CRISTIANE CORREIA DIAS (b-girl Cris) é mestra pela Faculdade de Educação da Universidade de São Paulo (FeusP), pesquisadora, arte-educadora e ativista da cultura hip-hop, dançarina de breaking. Licenciada/bacharelada em educação física, diretora executiva da Federação Paulista de Breaking.E-mail: slc.cris@ hotmail.com

DANIEL B. O. TEJERA (Daniel Garnet) é mestre em ciências da motricidade (Universidade Estadual Paulista "Júlio de Mesquita Filho" - UnesP), defendeu a dissertação Rap: o duelo de rimas no cotidiano do jovem. É um dos idealizadores do evento "Batalha Central", contemplado no Prêmio Hip-Hop/Funarte (2014). Atualmente é pesquisador no projeto "O ancestral e o contemporâneo nas escolas". Lançou com Peqnoh o álbum Avise o mundo - 30 melhores de 2015 pelo site Noticiário periférico.E-mail: olmedo.tejera@gmail.com 
ELAINE CRISTINA MORAES SANTOS é doutorado em educação pela Universidade de São Paulo (USP), mestrado em educação escolar pela UNESP de Araraquara e graduado em psicologia pela Universidade Metodista de Piracicaba (UnimeP). Atua na área de psicologia e educação em interface com a psicologia social. Sua prática, atualmente, circunda o campo acadêmico, social, clínico e educacional com foco nas seguintes temáticas de estudo: memória, tempo social, tecnologias digitais, juventude e formação étnico-racial. E-mail: elainecms@usp.br

ELIAS SANTOS é locutor-apresentador formado em comunicação social pela UFMG. Mestre em Comunicação Social pela UFMG, professor universitário nas áreas de Rádio e TV no Centro Universitário Una, no Centro Universitário Newton Paiva e na UFMG. Presidente da Empresa Mineira de Comunicação (Rádio Inconfidência e TV Minas), desde janeiro de 2018. Atuou como diretor artístico da Rádio Inconfidência; coordenador executivo/locutor/produtor da Rádio UFMG Educativa/FM 104,5, apresentador dos programas Caleidoscópio e Retratosna TV Horizonte, entre outros.E-mail: eliasufmg@gmail.com

ELISÂNGELA CHAVES é graduada em educação física pela Universidade Federal de Viçosa (UFV) (1995), mestre em educação pela UFMG (2002) e doutorada em educação pela mesma instituição (2013). Professora da área de dança no curso de educação física da UFMG. Coordenadora geral e acadêmica da educação a distância do Programa Esporte e Lazer da Cidade (PELC) e Vida Saudável, do Ministério do Esporte com participação da UFMG. Docente do Programa de Pós-Graduação em Estudos Interdisciplinares do Lazer. Coordenadora do Grupo de Pesquisas Edudança.E-mail: elischaves@hotmail.com

EUGÊNIO TADEU PEREIRA é professor no curso de graduação em teatro da Escola de Belas Artes (UFMG); integrante do Grupo Serelepe (EBA/UFMG), do Movimento da Canção Infantil Latino-Americana e do Caribe e da Associação Brasileira de Pesquisa e Pós-Graduação em Artes Cênicas (ABrace). É docente no Prof-Artes (EBA/UFMG); coordenador do "Serelepe: brinquedorias sonoras e cênicas", cofundador do Duo Rodapião, idealizador e coordenador do "Pandalelê: laboratório de brincadeiras" (CP/UFMG), mestre em educação (UFMG), doutor em artes cênicas (USP) e pós-doutor pela Universidade do Minho (Portugal).E-mail: eugenio.tadeu@yahoo.com.br

FELIPE VINÍCIUS DE PAULA ABRANTES é graduado em educação física pela EEFFTO/UFMG. Doutorando e mestre em estudos do lazer pelo Programa 
de Pós-Graduação Interdisciplinar em Estudos do Lazer da UFMG. Integrante do Grupo de Estudos sobre Futebol e Torcidas (GEFuT). Participa do grupo produtor de conteúdo para o programa Óbvio Ululante na Rádio UFMG Educativa. E-mail: felipevpa@yahoo.com.br

FERNANDA PERALTA é gestora pública, exerceu cargos no período de 2004 a 2015, elaborando políticas públicas para o meio ambiente nos municípios de Vassouras e Paty do Alferes e no Instituto Estadual do Ambiente (INEA), atuando como coordenadora técnica do Programa Coleta Seletiva Solidária do Estado do Rio de Janeiro, com ação em 82 municípios. Atualmente trabalha na gerência de educação ambiental do InEA, promovendo ações de apoio aos municípios para as políticas de educação ambiental. É professora convidada do curso de elaboração de planos de gerenciamento de resíduos sólidos, ministrado pela Evolutis Soluções Ambientais. E-mail: peralta.inea@gmail.com

GILMAR TONDIN é graduado em educação física pela Universidade Federal de Santa Maria (UFSM) e mestre em ciências do movimento humano pela Escola de Educação Física, Fisioterapia e Dança (UFRGS). Professor da Prefeitura de Porto Alegre, com atuação há mais de trinta anos nas políticas públicas de esporte e lazer. Membro do Grupo de Pesquisa F3P-Efice e, desde 2006, integra o grupo de formadores dos programas Pelc e Vida Saudável do Ministério do Esporte.E-mail: tondin.gilmar@gmail.com

GUILHERME CARVALHO FRANCO DA SILVEIRA é professor do Núcleo de Educação Física do Centro Pedagógico da Escola de Educação Básica e Profissional da UFMG, doutor em estudos do lazer (EEFFTO/UFMG), mestre em educação (UFMG), especialista em educação física escolar (PUC-MG) e licenciado em educação física (UFMG), com experiência em educação física escolar, projetos sociais e cursos de graduação e pós-graduação em educação física e pedagogia.E-mail: guilherme.cfs@outlook.com

GUSTAVO PEREIRA CÔRTES é graduado em educação física (UFMG) e fisioterapia (ciências médicas). Bailarino e coreógrafo, especializado em danças brasileiras. Mestre em educação pela UFMG. Doutor em artes pela Universidade Estadual de Campinas (Unicamp) (2013). Professor da área de Dança do curso de educação física (UFMG). Docente do mestrado profissional em artes, ProfArtes (EBA/UFMG) desde 2015. É diretor do Grupo Sarandeiros e cocoordenador do Grupo de pesquisas EDuDança. E-mail: gustavocortesufmg@ gmail.com 
JORGE QUINTÃO é fotógrafo documentarista, formado em engenharia industrial mecânica e mestre em estudos de linguagens, ambos pelo Centro Federal de Educação Tecnológica de Minas Gerais (CEFET/MG). É professor de disciplinas de projeto em cursos de graduação, MBA e pós-graduação. Coordenador, curador e idealizador do projeto Imaginário Coletivo e proprietário da Multiverse, empresa de design, inovação e audiovisual. E-mail: jorge.quintao@gmail.com

JOYCE KIMARCE DO CARMO PEREIRA é doutoranda e mestre em estudos interdisciplinares do lazer. Graduada em turismo pela UFMG. Especialista em gestão de políticas públicas pela UniCamp. Membro do Grupo de Pesquisa LuCE (UFMG/CNPq). Realiza pesquisas nas áreas do lazer, turismo e práticas sociais. E-mail: joycekimarce@hotmail.com

JUAN CARLOS PÉREZ MORALES é graduado em cultura física e esportes (Universidade Incca, Colômbia), especializado em administração esportiva (Fundação Universitária da Área Andina), mestre em educação física e doutor em ciências do esporte (UFMG). Professor da EEFFTO/UFMG. Pesquisador no Centro de Estudos em Cognição e Ação do Centro de Excelência Esportiva da EEFFTO/UFMG, na área de pedagogia do esporte (processo de ensino-aprendizagem-treinamento) e processos cognitivos inerentes à tomada de decisão nos jogos esportivos coletivos. Atua com gestão de políticas públicas e sociais de esporte escolar, eventos esportivos e atividade física e saúde. E-mail: jkperezmorales@gmail.com

JULIANA ARAÚJO DE PAULA é graduada em educação física pela UFMG (2010) e mestre em educação pela mesmo instituição (2017). Atualmente é professora da Rede Municipal de Educação de Belo Horizonte, atua na Diretoria da Educação Integral da Secretaria Municipal de Educação. Dançarina do Grupo Sarandeiros da UFMG. Desenvolve trabalhos e pesquisas relacionados à educação integral, Educação Física Escolar, Aprendizagem e Dança. E-mail: j.araujodepaula@gmail.com

JUNIOR VAGNER PEREIRA DA SILVA é doutor em educação física pela Universidade Católica de Brasília (UCB). Professor adjunto dos cursos de educação física e mestrado/doutorado interdisciplinar em saúde e desenvolvimento na Região do Centro-Oeste da Universidade Federal de Mato Grosso do Sul (UFMS), onde exerce as funções de chefe da coordenadoria de cultura e esporte da Pró-Reitoria de Extensão, Cultura e Esportes (ProECE). É tutor do Programa de Educação Tutorial e coordenador do Centro de Desenvolvimento 
de Pesquisa em Políticas de Esporte e de Lazer da Rede Cedes no Mato Grosso do Sul. Editor chefe da Revista Brasileira de Ciência e Movimento e presidente da ANPEL (2018/2020).E-mail: jr_lazer@yahoo.com.br

KARLA TEREZA OCELLI COSTA é professora no ensino fundamental da Prefeitura Municipal de Belo Horizonte, graduada em educação física pelo Centro Universitário de Belo Horizonte (UNIBH). Possui pós-graduação em educação física escolar pela Fundação Helena Antipoff e em gestão escolar pela UFMG, mestrado e doutorado em estudos do lazer pela UFMG, pesquisando sobre as identidades quilombolas sob a lente do Lazer. E-mail: ktocellicosta@ yahoo.com.br

LARISSA MARIA SANTOS ALTEMAR é educadora no MMGV, licenciada em teatro (EBA/UFMG) e mestra em educação pela UFMG. Fez graduação sanduíche na Itália (Università degli Studi di Firenze - UNIFI) (bolsa CAPES) e aperfeiçoamento em complexidade e prática social pela UFMG. Atua também como professora de teatro na educação básica, além de oferecer oficinas, no contexto de formação continuada, para professoras da educação infantil com a temática "Estética Teatral na EI". E-mail: laltemar@hotmail.com

MARIA CLARA LEMOS DOS SANTOS é professora do TU/UFMG, mestra em artes visuais (EBA/UFMG) e graduada em educação física pela EEFFTO/ UFMG. É atriz formada pelo TU/UFMG, possuindo formação em magistério, método Rességuier e trapézio voador. Foi educadora social no Circo de Todo Mundo, Belo Horizonte, e professora na Escola Nacional de Circo, Rio de Janeiro. Atualmente desenvolve pesquisas na área de teatro e circo (FAPEMIG, CNPq, TU/UFMG).E-mail: mariaclara-tu@ufmg.br

MARIANA MÓL GONÇALVES é professora do curso de cinema e audiovisual no Centro Universitário Una. Doutora em artes pela Escola de Belas Artes da UFMG, com pesquisa em cinema produzido na América Latina, mestre em artes pela UFMG. Possui experiência na área cultural, atuando principalmente em cinema e produção cinematográfica. Produziu e roteirizou o documentário Simplicidade: Mozart Secundino de Oliveira. Produtora do Lumiar Festival Interamericano de Cinema Universitário.E-mail: marianamol@gmail.com

MARINA DE MATTOS DANTAS é graduada em psicologia (PUC-MG), mestre em psicologia social (UERJ), doutora em ciências sociais (PUC-SP), pós- 
-doutoranda em estudos do lazer (UFMG). Pesquisadora no Grupo de Estudos sobre Futebol e Torcidas (GEFuT/UFMG).E-mail: marinamattos@gmail.com

PAMELA EMILSE NAUMANN GORGA é educadora no MMGV. Licenciada em História pela Facultad de Filosofía y Letras/ Universidad de Buenos Aires (FFYL/UBA), mestra e doutoranda na linha de pesquisa História e Culturas Políticas do Programa de Pós-Graduação em História da UFMG, com ênfase em História Medieval. Fez graduação sanduíche no Brasil (UFMG) (bolsa do Grupo Montevidéu).E-mail: panaumanngorga@gmail.com

RAFAEL FORTES é professor do Departamento de Ciências Sociais da Universidade Federal do Estado do Rio de Janeiro (Unirio) e do Programa de Pós-Graduação Interdisciplinar em Estudos do Lazer da UFMG. Doutor em comunicação. Editor executivo de Recorde: Revista de História do Esporte e coordenador do Grupo de Pesquisa Comunicação e Esporte da Sociedade Brasileira de Estudos Interdisciplinares da Comunicação.E-mail: raffortes@hotmail.com

REGINA CAFÉ é jornalista e musicista. Desenvolve trabalhos de percussão e construções de instrumentos por meio de resíduos há mais de trinta anos. Já realizou workshops em diversos países como: Bélgica, Alemanha, Egito e estados brasileiros. Atualmente coordena dez núcleos do projeto Funk Verde - Escola de Possibilidades Sonoras, em parceria com a Secretaria de Estado de Ambiente (SEA/INEA), no município e estado do Rio de Janeiro. E-mail: reginacafe.rc@ gmail.com

RODRIGO BARBOSA TERRA é professor de educação física pela UFRJ, mestre em educação pela Universidade Católica Dom Bosco, Mato Grosso do Sul (UCDB/MS) e doutor em ciência do exercício e do esporte pela UERJ. Faixa preta de Karatê $5^{\circ}$ Dan. Articulador regional dos programas federais PelC e Vida Saudável.E-mail: rodrigoterrams@gmail.com

ROGÉRIO LOPES DA SILVA PAULINO é professor do TU/UFMG, doutor em artes cênicas pela UNICAMP/ Instituto Universitário de Lisboa (ISCTE-Lisboa) e graduado em antropologia pela UFMG. É ator e diretor teatral, tendo se apresentado em festivais no Brasil e no exterior. Atuou como educador e coordenador de projetos de arte-educação para crianças e adolescentes de vilas e favelas. Coordena o projeto "Por um convívio criativo: o teatro na ocupação da cidade e de seus espaços públicos”. E-mail: turogerlop@gmail.com; site: www. teatroecidade.com 
ROMILSON AUGUSTO DOS SANTOS é doutor em educação pela UFBA (2011), mestre em educação pela mesma instituição (2001), licenciado em educação física pela Universidade Católica do Salvador (1987). É professor da UFBA e coordenador do colegiado de educação física. E-mail: romiss@ufba.br

SILVIO RICARDO DA SILVA é licenciado em educação física pela Universidade Gama Filho. Mestre em ciência do movimento humano pela UFSM. Doutor em educação física pela UNICAMP, pós-doutorado pela Universidade de Valência. Professor titular da EEFFTO/UFMG. Coordenador do GEFut.E-mail: prof.srs@ gmail.com

SÔNIA CRISTINA DE ASSIS é doutora em estudos do lazer e especialista em música pela UFMG. Mestre em educação, cultura e organizações sociais e graduada em licenciatura em educação artística/música, pela Universidade do Estado de Minas Gerais (UEMG). Docente da UEMG, atuando na formação de professores de música dos cursos de licenciatura em música. Desenvolve estudos em práticas tradicionais - Reinado e Reisado Mineiro - investigando elementos como musicalidade, corporalidade e aprendizagem.E-mail: assis.soniacris@ gmail.com

SUSANA GASTAL é doutora, pesquisadora e docente no Programa de Pós-Graduação em Turismo e Hospitalidade, mestrado e doutorado, na UCS. Possui estágio pós-doutoral (UCP-Porto), doutorado em comunicação social (PUC-RS) e mestrado em artes visuais (UFRGS). Bolsista produtividade CNPq. E-mail: susanagastal@gmail.com

THIAGO JOSÉ SILVA SANTANA é mestre em estudos do lazer (2016) e licenciado em educação física (2008) pela UFMG. Pesquisador do GEFuT. Cocoordenador do programa de rádio Óbvio Ululante. Membro do grupo Pensando a Educação Física Escolar. Professor da Rede Municipal de Belo Horizonte. E-mail: tejota14@gmail.com 



$$
\begin{aligned}
\text { Formato } & 14 \times 21 \mathrm{~cm} \\
\text { Papel miolo } & \text { Off-set } 75 \mathrm{~g} / \mathrm{m}^{2} \\
\text { Papel capa } & \text { Cartão Alta Alvura } 250 \mathrm{~g} / \mathrm{m}^{2} \\
\text { Tipologia } & \text { Minion Pro } \\
\text { Número de páginas } & 304 \\
\text { Tiragem } & 2.000 \\
\text { Impressão } & \text { Paym Gráfica e Editora LTDA. }
\end{aligned}
$$


CHRISTIANNE LUCE GOMES

É professora Titular na UFMG e coordenadora do Programa de Pós-Graduação Interdisciplinar em Estudos do Lazer. É pesquisadora do CNPq e líder do grupo de pesquisa LucE. Doutora em educação, com pós-doutorado em ciências políticas e sociais e estágio sênior na Universidade de Barcelona.

JOSÉ ALFREDO OLIVEIRA DEBORTOLI É professor na EEFFTO/UFMG. Docente no Programa de Pós-Graduação Interdisciplinar em Estudos do Lazer e no mestrado profissional da Faculdade de Educação - Promestre, ambos na UFMG. Doutor em educação pela PUC-Rio e pós-doutor em antropologia social pela UnB.

LUCIANO PEREIRA DA SILVA

É professor na EEFFTO/UFMG. Docente no Programa de Pós-Graduação Interdisciplinar em Estudos do Lazer da UFMG. Doutor em educação pela UFMG.
Neste livro o leitor vai encontrar uma rede de reflexões que se alimenta de práticas sociais que se convergem em mediações culturais como lazer na contemporaneidade. Estimulados em avançar as discussões de Joffre Dumazedier sobre os "conteúdos do lazer", os textos problematizam limites e possibilidades das experiências discutidas como participação social e efetivação de direitos de cidadania. Reflexões que vão do cinema à arte de transformar materiais recicláveis em instrumentos musicais, passando pelo rádio, fotografia, brincar, mídias digitais, hip-hop, dança, prática esportiva, lutas, capoeira, festa, prática gastronômica, museológica, teatro e circo. Isso dá para se ter ideia da abrangência e riqueza das abordagens que nos desafiam ao diálogo com essa obra.

\section{LEILA MIRTES MAGALHÃES PINTO DOUTORA EM EDUCACÃO E COORDENADORA CIENTIFICA DA REDE CEDES/SECRETARIA ESPECIAL DO ESPORTE}

\section{$\mathrm{U} F m \mathrm{G}$

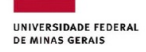

\section{AUTORES
ASSOCIADOS}

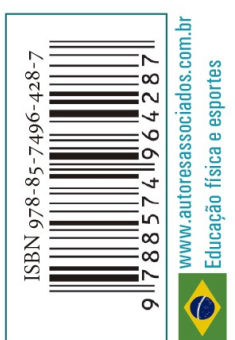

